\title{
Legal reforms for economic development in Africa: How effective?
}

Citation for published version (APA):

Ogo, I. (2018). Legal reforms for economic development in Africa: How effective? A comparative investigation of legal reforms to improve public debt management in Nigeria and Rwanda. [Doctoral Thesis, Maastricht University]. Datawyse / Universitaire Pers Maastricht. https://doi.org/10.26481/dis.20180124io

Document status and date:

Published: 01/01/2018

DOI:

10.26481/dis.20180124io

Document Version:

Publisher's PDF, also known as Version of record

\section{Please check the document version of this publication:}

- A submitted manuscript is the version of the article upon submission and before peer-review. There can be important differences between the submitted version and the official published version of record.

People interested in the research are advised to contact the author for the final version of the publication, or visit the DOI to the publisher's website.

- The final author version and the galley proof are versions of the publication after peer review.

- The final published version features the final layout of the paper including the volume, issue and page numbers.

Link to publication

\footnotetext{
General rights rights.

- You may freely distribute the URL identifying the publication in the public portal. please follow below link for the End User Agreement:

www.umlib.nl/taverne-license

Take down policy

If you believe that this document breaches copyright please contact us at:

repository@maastrichtuniversity.nl

providing details and we will investigate your claim.
}

Copyright and moral rights for the publications made accessible in the public portal are retained by the authors and/or other copyright owners and it is a condition of accessing publications that users recognise and abide by the legal requirements associated with these

- Users may download and print one copy of any publication from the public portal for the purpose of private study or research.

- You may not further distribute the material or use it for any profit-making activity or commercial gain

If the publication is distributed under the terms of Article $25 \mathrm{fa}$ of the Dutch Copyright Act, indicated by the "Taverne" license above, 


\section{Legal Reforms for Economic Development in Africa: How Effective?}

A Comparative Investigation of Legal Reforms

to Improve Public Debt Management

in Nigeria and Rwanda 


\section{Legal Reforms for Economic Development in Africa: How Effective?}

\section{A Comparative Investigation of Legal Reforms to Improve Public Debt Management in Nigeria and Rwanda}

\section{Dissertation}

to obtain the degree of Doctor at Maastricht University, on the authority of the Rector Magnificus, Prof. Dr. Rianne M. Letschert in accordance with the decision of the Board of Deans, to be defended in public on Wednesday $24^{\text {th }}$ January 2018 , at 14.00 hours

by

Ifeyinwa Ogo 



\section{Table of Contents}

$\begin{array}{ll}\text { List of Tables } & 7\end{array}$

List of Figures $\quad 8$

List of Abbreviations $\quad 9$

Chapter 1 Law and Economic Development 11

1.1. Law and Economic Development in Africa 13

1.2. Contemporary Law and Development: An Overview 15

1.3. The New Law and Development: Governance and Law Reform 20

1.4. Rationale for Study 22

1.5. Which Way Forward: Law and Economic Development 25

1.6. Research Questions 27

1.7. Chapter Outline 27

1.9. Importance of Study 30

Chapter 2 The Context of Debt Relief 33

2.1. The Context of Debt Relief in 2005

2.3. The Failures of Structural Adjustment Programs 52

2.5. Development, not Debt Burdens 60

2.6. Analysing the Relationship between Law and Economic Development through the Debt Burden Experiences of Nigeria and Rwanda 62

2.7. Summary 64

Chapter 3 Reforms for Debt Relief 67

3.1. International Finance Institutions and Policy Reforms for Debt Relief 69

3.2. Institutional and Legal Reforms driven by the Poverty Reduction and $\begin{array}{ll}\text { Strategy Papers } & 76\end{array}$

3.3. Nigeria Poverty Reduction Strategy Paper 78

3.4. Rwanda Poverty Reduction Strategy Paper 88

3.5. Reforms: Laws and Institutions for Debt Relief 96

3.6. Summary 98

Chapter 4 Evaluating the Effectiveness of Legal Reforms to Regulate Government Management of Public Debt and Foster Debt $\begin{array}{ll}\text { Sustainability } & 101\end{array}$

4.1. Legal Reforms, Public Debt Management and Debt Sustainability 103

4.2. Nigeria: The Fiscal Responsibility Act 2007 and Nigeria's External Debt Portfolio 105

4.3. The Fiscal Responsibility Act 2007 and Public Debt Management 108 
4.4. Evaluating the Fiscal Responsibility Act 2007

4.5. Rwanda: The Law on State Finances and Property 2013 and Rwanda's Debt Portfolio

4.6. Evaluating the Law on State Finances and Property 2013

4.7. Discussion: Legal Reforms for Debt Management and Debt Sustainability

4.8. Summary

Chapter 5 Discussion: Law, Institutions and Economic Development

5.1. Revisiting the Theoretical Point of Departure: Limitations of Legal Reforms Influenced by New Institutional Economics

5.2. Proposition: Evaluate Law Against Outcomes

5.3. Summary

Chapter 6 Conclusion

6.1. Revisiting the Research Questions 160

6.2. Contributions to Field of Study

6.3. Limitations of Study

6.4. Opportunities for Further Research

6.5. Concluding Statement 


\section{List of Tables}

Table 1: The World Bank Group Lending and Operations 37

Table 2: $\quad$ IMF Lending and Operations 40

Table 3: Institutional Overview and Lending Operations of the African Development Bank Group 41

Table 4: $\quad$ Nigerian Government Borrowing 1975-1985 44

Table 5: Increase in Nigeria's Debt Obligations 1985-2005 48

Table 6 Rise in Rwanda's external debt obligations between 1976 and $1994 \quad 52$

Table 7: $\quad$ Debt Sustainability Analysis of the HIPC Initiative 71

Table 8: $\quad$ IMF and World Bank Debt Relief Mechanisms 1999-2014 73

Table 9: $\quad$ Criticisms of WB/IMF HIPC Claims 76

Table 10: $\quad$ DMO Act- Functions of DMO for Debt Management 87

Table 11: $\quad$ Purposes for which the Government of Rwanda may borrow under the Organic Budget Laws 93

Table 12: $\quad$ Authority to Borrow under the Organic Budget Laws 94

Table 13: Debt Management under the Organic Budget Laws 94

Table 14: Debt Management Strategy under the Organic Budget Laws 95

Table 15: $\quad$ Debt Relief and Legal Reforms 98

Table 16: $\quad$ Tools for Debt Sustainability Analysis 104

Table 17: $\quad$ Ratings under the IMF Debt Sustainability Framework 104

Table 18: Debt Burden Thresholds under the DSF 105

Table 19: $\quad$ Nigeria Public Debt: 2011-2015 106

Table 20: Rwanda: Accumulation of Public Debt 2006-2014 120

Table 21: Public Debt Management Provisions of Budgetary Legislation in $\begin{array}{ll}\text { Nigeria and Rwanda } & 127\end{array}$

Table 22: Sample Framework for Outcome-Based Evaluation of Law 148

Table 23: Comparative Table of Outcome-Based Evaluation and IFI Indexes $\quad 150$

Table 24: $\quad$ Law as a Manager of Competing Interests 167 


\section{List of Figures}

Figure 1: $\quad$ Nigeria's External Debt Stock 1977-1985 45

Figure 2: $\quad$ Nigeria's External Debt and Percentages Owed to Creditors in $2005 \quad 48$

Figure 3: Rwanda's External Creditors in 1994

Figure 4: Debt Relief Mechanisms of the Paris Club 59

Figure 5: Debt Acquisition Process under the Fiscal Responsibility Act $2007 \quad 83$

Figure 6: Institutional Matrix to Govern Borrowing Limits 84

Figure 7: $\quad$ Nigeria: Public Debt 2011-2015 (US\$ millions) 106

Figure 8: $\quad$ Nigeria: External Debt Composition in 2015

Figure 9: Federal Government: Total Public Debt Service 2011-2015 (US\$ millions) 112

Figure 10: Rwanda External Debt Acquisition Process 119

Figure 11: Rwanda: Accumulation of Public Debt 2006-2014 121

Figure 12: Percentage Composition of Rwanda's External and Domestic Debt: 2003-2014

Figure 13: Composition of Rwanda's External Debt 2014 


\section{List of Abbreviations}

African Development Bank

AfDB

African Development Fund

AfDF

Country Policy and Institutional Assessment

CPIA

Debt Management Office

DMO

Debt Sustainability Framework

DSF

Debt Sustainability Framework for Low Income Countries

DSF-LIC

Enhanced Structural Adjustment Facility

ESAF

Federal Account Allocation Committee

FAAC

Fiscal Responsibility Act

FRA

Forum on Debt and Development

FONDAD

General Agreement on Trade and Tariffs

GATT

Good Governance Index

GGI

Gross Domestic Product

GDP

Group of Seven

G7

Heavily Indebted Poor Countries

HIPC

Inter-American Development Bank

IADB

International Bank for Reconstruction and Development

IBRD

International Centre for the Settlement of Investment Disputes

ICSID

International Development Association

IDA

International Finance Corporation

IFC

International Finance Institution

IFI

International Fund for Agricultural Development

IFAD

International Monetary Fund

IMF

Import Substitution Industrialisation

ISI

Irrevocable Standing Payment Order

ISPO

Local Economic Empowerment and Development Strategies

LEEDS

La Porta, Lopez-de-Silanes, Shleifer and Vishny

LLSV

Millennium Development Goals

MDGs

Ministry of Finance and Economic Planning

MINEFCON

Multilateral Debt Relief Initiative

MDRI

Multilateral Investment Guarantee Agency

MIGA

Multinational Enterprise

MNE

National Economic Empowerment and Development Strategy

NEEDS

New Institutional Economics

NIE

New International Economic Order

NIEO

National Investment Planning Unit

NIPU

Net Present Value

NPV 
Organisation of African Unity

OAU

Organisation of Petroleum Exporting Countries

OPEC

Permanent Sovereignty Over Natural Resources

PSNR

Policy Support Instrument

PSI

Poverty Reduction and Growth Facility

PRGF

Poverty Reduction Strategy Paper

PRSP

Rwanda Political Front

RPF

State Owned Enterprises

SOE

State Economic Empowerment and Development Strategies

SEEDS

Structural Adjustment Program

SAP

Sustainable Development Goals

SDGS

United Nations Development Program

UNDP

United Nations Industrial Development Organisation

UNIDO

Union of Soviet Socialist Republics

USSR

World Trade Organisation

WTO 
Chapter

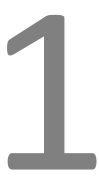

\section{Law and Economic Development}


The African continent is many things: a tourist attraction, an investment destination, a charity occupation etc. For a lawyer, the continent poses a challenge, which forms the principal question of this scholarly exercise - what legal systems, structures and strategies will enable the conversion of Africa's vast resources and potential to economic benefits for her people? Alternatively, how can laws and legal systems be designed and deployed for the purpose of driving economic development in Africa?

Economic development has been described as a phenomenon which combines selfsustaining growth with structural change in patterns of production, upgrades in technology, modernisation in society, polity and institutions, and widespread improvement in the human condition (Adelman, 2001). A second definition is that economic development provides governments and international economic organizations with tools for economic transformation (Toye, 2003). The very term development is suggestive of a benchmark, or a standard yet to be attained. This benchmark is often put forward as the attainment of an industrialized economy. According to the United Nations Industrial Development Organisation (UNIDO), the critical importance of industrialization to development is made clear through Sustainable Development Goal (SDG) 9, which speaks to the necessity of technology and infrastructure for economic productivity (United Nations Industrial Development Organization, 2016). Also, it is necessary to note that economic growth is distinguished from economic development; while the former is a calculation of economic performance over a period of time, economic development is concerned with the quality of the policies, institutions and activities that direct an economy.

With fifty-four countries and one billion people, the African continent is too vast and diverse to be considered as a single entity. Accordingly, this research project concentrates on a comparative examination of the relationship between law and economic development in the Federal Republic of Nigeria and Republic of Rwanda. During the last two decades of the $20^{\text {th }}$ century and the first decade of the $21^{\text {st }}$ century, these countries implemented similar economic and institutional reform programs to accelerate economic development. The economic structures of both countries are disparate, and present an opportunity to investigate the interplay of legal systems and the process of economic development in different contexts: Nigeria is categorized as a lower-middle income country (United Nations Industrial Development Organization, 2016), while Rwanda is classified as a low income country (United Nations Economic Commission for Africa, 2015). Nigeria and Rwanda represent the western and central/eastern regions of sub-Saharan Africa respectively. Also, both countries are similar in that they have heterogeneous populations, a colonial experience, and an average of twenty years maintaining a democratic system of government.

This chapter serves a dual purpose; firstly, to outline the evolution of law and economic development as an academic field of study, and as an area of professional practice. Secondly, the chapter begins the inquiry into the relationship between law and economic development in Nigeria and Rwanda. 


\subsection{Law and Economic Development in Africa}

The multidimensional nature of development renders difficult attempts to find and apply a simple definition of Law and Development, or articulate a linear list of the elements which compose this field of study. Discussing this difficulty, Mariana Mota Prado categorizes the work of Law and Development scholars into two groups. The first group, whose work she terms 'Law in Development' considers how law can play an instrumental role in achieving development goals. This body of work will form the foundation for this study. The other group, which views the rule of law and legal reform as development ends in themselves is termed as 'Law as Development' (Prado, 2010). For the purpose of this study, economic development will be taken as the achievement of economic objectives as put forward by national governments' policies. In this context, the purpose of laws and legal systems is to function for the successful actualisation of economic agenda, thus placing this study in the law in development group, specifically law in economic development.

The roles, functions and impact attributed to law and legal institutions in the economic development of the African continent have morphed several times over the last sixty years. Theories of Law and Development abound, ranging from narrow fields of study confined to the use of law in improving economic performance, to those expanded to analyse the ways in which legal structures shape social interaction. The common denominator of these divergent approaches and objectives is the assertion that the formulation and application of laws directly impact upon the evolution and performance of economies and societies.

However, the conceptions, definitions, typologies and utilisations of law vary according to the users, which include, but are not limited to lawyers, political scientists, economists, social activists, investors, and regulators. It is not the purpose of this study to engage in the scholarly debate as to the role of law and institutions in the development process. Rather, the study recognizes that it is worthwhile to evaluate theories against results, after decades of discourse and disagreement. Law is an instrument amenable to divergent purposes, and will create impact dependent on its users, and the environment in which it is deployed. The trajectory of contemporary African economic development is governed by domestic, international and multilateral legal systems which legitimize and underpin the political, economic and ideological objectives of their owners. Also, the law is often a weapon in conflicts within African development practice, particularly the measurements of economic performance, the choices of strategies to deliver improved economic performance, and the methods by which strategies should be implemented.

To illustrate, let us assume that a resource rich developing country in Africa is in contract negotiations with a Multinational Enterprise (MNE) regarding a large-scale investment into natural resource exploration and production. A government lawyer will consider this contract to be evidence of economic development, as he expects the MNE 
to benefit the local economy; the MNE will create jobs for citizens, who will pay tax from their income, the MNE itself will pay corporate tax, provide linkages with the international economy, introduce advanced technology, and catalyze growth for domestic enterprises who will sell it goods and services. This lawyer is concerned with international agreements- how these impact upon state sovereignty and negotiating power, the laws which ensure that the investor contributes to the growth of the business environment, as well as investor protection, taxation, technology transfer, amongst other issues. The investor's lawyer on the other side of the table considers his contribution to global economic development to be the facilitation of the MNE's access to natural resources and foreign markets. S/he looks at the agreements to understand what laws, national and international, will govern the investment contract, and then s/he reviews the domestic regulatory framework which will either provide government support for, or frustrate the MNE's business activities. Also, s/he is careful to assess whether the government, through laws and state institutions, upholds property rights which protect capital, assets, and intellectual property. Thereafter, s/he insists on certain dispute resolution mechanisms and investment guarantees, as well as land and tax concessions. Leaving the negotiation meeting, these lawyers may be accosted by yet another lawyer, who is an advocate for 'national development'. This lawyer considers the agreement reached between the government and investor deleterious to the environment, local economy and citizens. Specifically, s/he objects to the absence of 'local content' terms requiring the investor to employ citizens and protect the environment, and opposes a land concession which displaces communities and infringes on their property rights.

This simplistic illustration aims to show the various legal elements considered to contribute to economic development, and the multiple areas and perspectives at which legal systems intersect with economic activity. It is impractical to consider all of the issues in Law in Development in a single scholarly study. Also, it is difficult to create a hierarchy of legal issues for evaluation, as an individual issue can be of importance to different actors for different reasons.

This study argues for a more nuanced approach of investigation and analysis of the interactions and intersections of law in the economic development of Africa. Evidence based probing of the relationship between law and economic processes, will allow clear understanding of the current functionalities of legal systems for economic development. Secondly, the contexts and factors which should be accounted for in the design of legal interventions will be outlined and contextualised. This is necessary to design the legal systems and interventions which can allow the utilisation of law as an effective tool for economic development. It is important to note that this thesis does not undertake evaluations of economic policy, nor does it promote specific theories or approaches to economic development. The primary concern of this investigation is to observe and analyse the interplay of laws and economic systems, and observe economic outcomes influenced by legal instruments which function as tools of economic management. 
Academic inquiry must take place within a defined field of study. In this case, it is necessary to discuss the evolution of the prominent Law and Development theories which have influenced economic development policy on the African continent. This inquiry begins with the Law and Development movement which emerged in the immediate post-independence period of the 1960s.

\subsection{Contemporary Law and Development: An Overview}

The period immediately following the Second World War (1939-1945) was characterised by the disintegration of empires, the creation of newly independent states, and the emergence of international institutions to manage global political and economic relations.

In 1944, the International Bank for Reconstruction and Development, also known as the World Bank, and the International Monetary Fund (IMF) were set up to facilitate reconstruction and development, promote foreign investment, and promote long-range balance of trade (United Nations Monetary and Financial Conference, 1944). In 1945, the United Nations was established as an international political and economic organisation to promote peace, cooperation, human rights, and harmonise actions of nations in the achievement of common ends (United Nations, 1945). Similarly, The General Agreement on Tariffs and Trade (GATT), established in 1948, now the World Trade Organisation (WTO), is a system of law, supported by a legal institution to regulate international trade (General Agreement on Tarrifs and Trade, 1948). Collectively, these organisations have shaped guiding the ideologies, and supplied, or withdrawn a significant amount of the reputational and financial support used by countries for economic advancement.

\subsubsection{0s-1970s: The Era of State-led Development}

In newly independent countries, laws and legal systems were prescribed as necessary tools for economic development. The rationale for law as an instrument of economic improvement can be found in the 1961 report of the International Legal Studies Program at Harvard University;

"At this date, there is general awareness of the world-wide importance of the rapid and orderly economic development of the newly changing societies of Latin America, Asia and Africa. On the record there are good reasons to anticipate that the contribution of the legal profession can be of major importance, since a legal framework will be essential to the task, and its execution will involve legal processes" (Harvard Law School, 1961, p. 3).

The Law and Development movement was concerned with bridging the gap between laws in books, and law in practice. The majority of legal aid projects were fi- 
nanced by the United States Agency for International Development (USAID), and directed towards training of lawyers and judges. The movement was influenced by the economic theory of modernization which promoted economic development driven by state or government led investment in capital projects. A principal objective of the movement was "to bring about major changes in legal systems and norms in the interests of efficiency and justice. It involved an effort to create an academic field in legal studies that would parallel subfield like development economics and development administration. Law and development had a happy life, then faded from the scene" (Trubek, 1996, p. 223).

In 1974, Trubek and Galanter (1974, p. 1063), leading proponents of Law and Development declared the movement as failed, and explained that "law and development studies originated largely as by-products of "development assistance" activities by the United States government, international agencies, and private foundations working with governments and institutions in the Third World". They went on to posit reasons for the limited effectiveness of the law and development movement in driving economic development, or modernisation to: the absence of a theoretical framework, a lack of cohesion amongst different strands of thought, weaknesses in assumptions of the ethnocentric models of law, the possible irrelevance of law in economic development, and the amenability of laws to be used for negative outcomes.

\subsubsection{African Approaches to Law and Economic Development}

In the 1960s and 1970s, African Governments relied upon legal instruments to challenge the international economic system, and entrench governments in national economies. At international level, the United Nations General Assembly, in which these countries had a numerical majority, was the stage for political and economic assertion. In 1962, the General Assembly of the United Nations issued a Resolution titled 'Permanent Right to Sovereignty over Natural Resources' (PSNR). S1 of this Resolution states "The right of peoples and nations to permanent sovereignty over their natural wealth and resources must be exercised in the interest of their national development and of the well-being of the people of the State concerned" (United Nations General Assembly, 1962). A decade later, in 1974, the United Nations General Assembly (1974) adopted a Resolution on a New International Economic Order (NIEO). The articles of the NIEO sought to increase the powers of developing countries to regulate foreign investment, and expropriate or nationalise foreign owned investments on terms dictated by host countries. Also, the NIEO contained a revision of the terms of international trade, particularly tariffs, and the removal of conditions attached to economic and technical assistance. Like the PSNR 1962, the NIEO was an instrument of 'soft law', which expressed the aspirations of signatory countries, but was not enforceable as an international treaty or agreement. 
From the mid-1960s, dependency theorists such as Andre Gunder Frank asserted that industrialised countries, had through colonialism, structured the international economic system to keep former colonies in a state of underdevelopment through a system of resource extraction (Frank, 1966). While scholarly interest in the relationship between legal systems and economic development waned, the economic theory of Import Substitution Industrialization (ISI) gained prominence. This theory which emerged during the late 1960s directed that developing countries could move towards industrialization through the domestic production or manufacture of goods which were previously imported (Alexander, 1967). African countries which adopted ISI include Nigeria, Ghana, South Africa, Uganda, Botswana, Cameroon, Ethiopia, Kenya, Algeria, Tanzania, Zambia, Zimbabwe, Guinea, and Benin Republic, amongst others (Babatunde, 2012). ISI, as interpreted during this period placed the state as the lead agent and driver of economic development, and influenced the Governments of African countries to deploy laws as instruments of economic assertion, particularly over the ownership of natural resources, and the direction of economic activities.

As a result, State-Owned Enterprises (SOEs) gained popularity: by the end of the 1970s, on the average, SOEs accounted for up to 17 per cent of Gross Domestic Product (GDP) in African countries (Nellis, 2005). Often backed by legislation, these enterprises government owned, controlled and managed, enjoyed monopolies of industries. SOEs were underpinned by the belief that:

"publicly owned firms would be better-i.e., more rational and socially beneficialinvestors, that they would fill "entrepreneurial gaps," gain access to international concessionary and commercial credit denied to small local business-people, provide services the private sector either would not or could not (or even, to some, should not), and generally serve as training centers where Africans would acquire the technical and administrative skills required in a modern economy" (Nellis, 2005, p. 13).

According to Ngozi Okonjo-Iweala, former Managing Director of the World Bank and Minister of Finance of Nigeria, during the 1960s and 1970s, African Governments considered themselves to be the primary drivers of economic development, and providers of critical infrastructure and services to support economic activity. Also, she notes that due to the relative weakness of the private sector after independence and limited availability of private capital, these governments participated actively in many sectors of the economy, especially as government spending was expected to produce 'multiplier effects' (Okonjo-Iweala, 2012). Through SOEs, African governments sought to direct and manage the process of economic development. This approach was maintained until the implementation of structural economic reforms programs in the 1980s, which was caused by the international debt crisis of the early 1980 s. 


\subsubsection{0s: Reforms to Enable Investor-led Economic Development}

Law and Development as a field of study and area of practice re-emerged during the debt crisis of the 1980s. The debt crisis was triggered by the inability of developing countries to service loans which were obtained during the period of economic boom (high prices for petroleum products and commodities) in the 1970s. The IMF provided assistance towards economic recovery in the form of loans, which were contingent on economic re-structuring, as well as the reform of legal systems and state institutions (See Chapter 2 for extensive discussion). These reforms were concerned with the reduction of government participation in the economy and the creation of an enabling environment for private investors. Importantly, these reforms shifted the lead role in economic development to the private sector, and international investors in particular: "from 1979 to 1989, the World Bank approved, worldwide, 98 structural adjustment operations with SOE-related components. Most of these were supported by parallel technical assistance loans or credits. African cases accounted for 70 per cent of the total World Bank SOE-related adjustment universe in the 1980s" (Nellis, 2005, p. 11). Through Structural Adjustment Programs (SAPs), the functions of government were reduced to regulation and investor protection. International investors, typically originating from western countries were considered to possess the efficient systems, as well as the technology, resources, experience and expertise necessary to drive economic growth. Legal systems were often a practical impediment to international investment, which generated the need for legal reform, and the establishment of legal systems based on best practices. These best practices were often modelled on the laws of economically advanced countries (World Bank, 2000).

\subsubsection{0s-1990s: Economists Enter the Fray}

The late 1980s and early 1990s brought an institutional approach to development discourse and practice, which was led by the New Institutional Economics (NIE) school of thought. Economists further expanded the law and development field based on the argument that the governance structures which manage economies, otherwise known as institutions, are central to economic performance. Douglass North argued that "the institutional framework dictates the kinds of skills and knowledge perceived to have the maximum pay-off..If the institutional matrix rewards piracy (or more generally redistributive activities) more than productive activity, then learning will take the form of learning to be better pirates" (North, 1995, p. 21). North defined institutions as "the rules of the game of a society, or, more formally, the humanly devised constraints that structure human interactions. They are composed of formal rules (statue law, common law, regulation), informal constraints (conventions, norms of behaviour, and selfimposed codes of conduct), and the enforcement characteristics of both" (North, 1995, p. 23). 
In similar vein, and during the same period, the Legal Origins school of thought emerged. Legal Origins scholars hold that economic performance is determined by the national legal system, itself the consequence of historical evolution. Legal Origins, put forward by La Porta, Lopez-de-Silanes, Shleifer and Vishny (LLSV), began as an analysis of share-holder protection laws in Europe, but was expanded, then used to explain comparative economic performance. LLSV put forward theoretical, and empirical evaluations of legal systems to argue firstly, that better legal protection of investors will lead to more investment: "legal protection of outside investors limits the extent of expropriation of such investors by corporate insiders, and thereby promotes financial development" (La Porta, et al., 2008, p. 285). Secondly, national legal systems, and their treatment of investors are dependent on the historical factors and evolution of law, i.e., the origins. The operation of these legal systems as related to investor protection are a strong determinant and indicator of financial development.

According to LLSV, the historical evolution of legal systems in France and England in the $12^{\text {th }}$ and $13^{\text {th }}$ centuries has shaped the present day structural differences in the functionalities of legal systems of both countries. The common law is evolutionary, with disputes resolved by an argumentative and trial-based judicial system. In contrast, the more authoritarian French civil law system is code-based, reliant on investigations and documentation. LLSV found that the "French civil law system exhibits systematically less protection for minority shareholders, which is in turn correlated with concentrated share ownership; and corporations in common law countries (with stronger shareholder protection) pay out more dividends and have higher share prices than firms in civil law countries" (Armour, et al., 2009, p. 583). The English common law system is associated with (a) better investor protection, which in turn is associated with improved financial development, better access to finance, and higher ownership dispersion, (b) lighter government ownership and regulation, which are in turn associated with less corruption, better functioning labour markets, and smaller unofficial economies, and (c) less formalized and more independent judicial systems, which are in turn associated with more secure property rights and better contract enforcement" (La Porta, et al., 2008, p. 298). These differences are said to extend to those countries which derive their legal systems from England and France as a result of conquest and colonialism. The implications for former African colonies is thus: francophone African countries will have inherited legal systems which have inherently designed to offer weak protection to investors. Conversely, former British colonies are notionally better equipped to offer good protection to investors.

LLSV and NIE are similar in approach, which is to posit a correlation between the quality of laws and economic performance: NIE scholars assert the notion of causation, i.e., that laws have a direct and measurable effect on economic performance. In comparable fashion, Legal Origins claims that the treatment of investors by legal systems determines financial development, and ultimately economic development. To explain the current workings of institutions, both schools of thought look to historical factors; legal 
origins attributes the functions and operations of legal systems to historical evolution. Similarly, NIE scholars have argued that institutions established by colonists were intentionally designed to support resource extraction, rather than sustainable systems for national economic development (Acemoglu, et al., 2001; Acemoglu \& Robinson, 2012). Also, the use of econometric tools by LLSV and NIE have integrated a quantitative or statistical element to the analysis of the relationship between law and economic development.

\subsection{The New Law and Development: Governance and Law Reform}

In 1989, the World Bank reported a 'crisis of governance' in sub-Saharan Africa (World Bank, 1989). In its 1992 Governance and Development document, the World Bank defined governance as the "exercise of authority, control, management, power of government" (World Bank, 1992, p. 1). In the context of development, governance is concerned with the "management of a country's economic and social resources for development" (ibid). Governance conditionality was attached to loans provided by International Finance Institutions (IFIS) in order to induce the adoption of good policies and institutions which would enhance the effectiveness of development finance. In 1980 the average number of good governance conditions per loan stood at 21, rising to 55 by 1990, which reduced to 33 conditions per loan in 2000 (World Bank, 2001). Between 1996 and 2015, using the World Governance Indicators, the World Bank reported the quality of individual and aggregate governance indicators in 215 economies for six dimensions of governance; voice and accountability, political stability and absence of violence, government effectiveness, regulatory quality, rule of law, and control of corruption (World Bank, 2017).

The fall of communism and the breakup of the former Union of Soviet Socialist Republics (USSR) rekindled the interest of international institutions and scholars in law and development, especially the capabilities of laws to be deployed as instruments of economic and social engineering. The new Law and Development movement birthed the impetus and rationale for a wave of legal reform; multilateral agencies adopted governance agendas and re-introduced law to development practice. The 'Rule of Law' emerged as the dominant theme, to be deployed as an instrument to achieve two complementary objectives; firstly, an enabling market environment through the "protection of property rights, third party enforcement of contracts, and a stable, crime-free investment environment" (Barron, 2005, p. 9). Secondly, the rule of law in the political environment would facilitate good governance and democratisation. This approach is reminiscent of the instrumental view of law adopted by the Law and Development movement of the 1960s. However, the new Law and Development movement differed from its predecessor in its reduction of the role of governments in the economy, and its ideological backing drawn from the work of NIE. 
The term 'rule of law' is somewhat unwieldy, and has been used to capture a range of ideals and outcomes. Tamanaha (1995, p. 476) has opined that the rule of law "has always consisted more of a bundle of ideals than a specific or necessary set of institutional arrangements". Ibrahim Shihata, General Counsel of the World Bank between 1983 and 1998 conceptualised the rule of law as a system of abstract rules applied appropriately by functioning institutions (Shihata, 1995). This definition has been described as "purely economic: to create a stable, predictable legal environment in which economic actors came come together and transact, free from the arbitrary interference of government" (Barron, 2005, p. 15). In 2002, General Counsel Ko-Yung Tung of the World Bank expanded this definition, and provided metrics which speak to the quality, effect and purpose of the rule of law:

(1) The government itself is bound by the law;

(2) every person in society is treated equally under the law;

(3) the human dignity of each individual is recognised and protected by the law; and

(4) justice is accessible to all. The rule of law requires transparent legislation, fair laws, predictable enforcement, and accountable governments to maintain order, promote private sector growth, fight poverty, and have legitimacy. (Tung, 2002)

It has been argued by senior staff of the World Bank that "improving the functioning of legal institutions is an essential part of economic development", especially in the provision of three necessary ingredients of a well-functioning legal system in a market economy: the supply of market friendly laws, supportive institutions and demand for laws (Gray, 1997, p. 14). The effectiveness of national legal systems for the functioning of market economies is measured by a range of indices, including the 'Doing Business Reports' (World Bank), which are "a series of annual reports measuring the regulations that enhance business activity and those that constrain it. Doing Business presents quantitative indicators on business regulations and the protection of property rights that can be compared across 189 economies-from Afghanistan to Zimbabwe-and over time" (World Bank, 2016). These indicators measure the ease of starting a business, dealing with construction permits, getting electricity, registering property, getting credit, protecting minority investors, paying taxes, trading across borders, enforcing contracts, and resolving insolvency (ibid). In a bid to improve rankings on the Doing Business Index, "between June 2014 and June 2015, 189 economies worldwide documented 231 business reforms, with $71 \%$ of reforms aimed at reducing the complexity and cost of complying with business regulation, and $29 \%$ of reforms aimed at strengthening legal institutions. Sub-Saharan Africa alone accounts for $30 \%$ of the regulatory reforms making it easier to do business in 2014/15, followed closely by Europe and Central Asia" (ibid). The Doing Business Index has been hailed by scholars affiliated to NIE and the World Bank as a tool which enables informed policy debate on institutional reform, and an index which promotes economic inclusivity as it measures economic success on the basis of rules, not connections and corruption (Acemoglu, et al., 2013). 
Similarly, the Country Policy and Institutional Assessment (CPIA) is a "diagnostic tool that is intended to capture the quality of a country's policies and institutional arrangements-i.e., its focus is on the key elements that are within the country's control, rather than on outcomes (such as growth rates) that are influenced by elements outside the country's control" (World Bank, 2014). The CPIA rates countries "against a set of 16 criteria grouped in four clusters: economic management, structural policies, policies for social inclusion and equity, and public-sector management and institutions" (World Bank, 2015). The World Bank provides two reasons for this evaluation exercise: firstly, good policies and institutions are expected to lead to favourable outcomes, including growth and poverty despite possible fluctuations caused by internal and external factors. The thinking is that country-led development efforts are more successful than transplantations or importations. Also, CPIA ratings help determine the relative sizes of the Bank's concessional lending and grants to low-income countries" (World Bank, 2014).

Governance and the Rule of Law remain as dominant themes in economic development, emphasized in international development agenda through the work of multilateral institutions at international level, and at national level through governments which seek to align with this agenda. Thus, this study concentrates on the interplay of governance, laws and institutions as can be examined in the trajectory of African economic development.

\subsection{Rationale for Study}

The centrality or importance of law to economic development is the common thread flowing from the Law and Development movement of the 1960s to the contemporary thinking about Institutions and Development. However, in the context of African economic development, it is imperative to understand how economic systems interact with these legal concepts, in order to build legal systems which can enable economic development. The work of NIE, legal origins, and reform efforts led by IFIs have not yet delivered robust and effective models for legal reform; despite two generations of reforms, African economies and institutions remain on the lower rung of governance and economic indices. Thus, it is necessary to identify the factors that have limited the efficacy of the institutions approach.

Firstly, NIE assumes a model of economic development which is investor-centric. As a result, the legal issues which are considered important are those which touch on investor protection, e.g., the rule of law and property rights, as well as investorgovernment relations. In a 1997 report, the International Monetary Fund argued for a broader range of institutional reforms to enable countries "establish and maintain private sector confidence and thereby lay the basis for sustained growth" (International Monetary Fund, 1997, p. V). This perspective does not account for the multiplicity of 
trajectories of economic development. Importantly, it does not build models which consider or integrate other actors, for example the informal sector, government-led or government supported investment projects, into mainstream economic development.

Davis and Trebilcock (2008, p. 903) argue that

"many of the implications of NIE for legal reform resemble the ones advanced by modernisation theory a decade earlier. In terms of substantive law, from this perspective, core priorities should be attached to well-defined and alienable private property rights; a formal system of contract law that facilitates impersonal contracting, a corporate law regime that facilitates the capital investment through ease of incorporation and limited liability of small and medium sized enterprises and minimises agency costs faced by shareholders in general in the case of non-owner managed firms with controlling shareholders a system of secured lending that makes it easy for creditors to take a broad range of assets as collateral, identify competing claims to those assets as collateral, identify competing claims to those assets, and seize and sell the assets in the event of default; a bankruptcy regime that induces the exit of inefficient firms and redeployment of their assets to higher-valued uses; and a non-punitive, nondistortionary tax regime. In order to ensure the enactment and enforcement and administration of these substantive laws, priorities include designing law making institutions that are transparent and stable in their commitment to basic legal norms and inclusive in the stakeholders to whom they are responsive and law enforcement and administrative institutions that are competent, non-corrupt, free of undue political influence, procedurally transparent, and effectively resourced."

Secondly, institutional thought is expansive and does not mark clear boundaries between legal practice and other fields. Chang (2007, p. 17) observes that "one fundamental difficulty involved in the study of the relationship between institutions and economic development is that there is no widely accepted definition of institutions". Academic studies have presented econometric evidence which shows strong correlation between the quality of institutions and laws, and economic performance. Within the institutions and development sub-field, the elements of law required for economic development include wide-ranging and far-reaching concepts, including the rule of law, property rights, regulation, courts, and more. Institutional development scholars are yet to agree upon a defined scope of inquiry. It remains a herculean task to identify the primacy, and order by which legal elements and institutions should be embedded within developing African economies. IFIs have attempted to catalyse change in African economies through conditionalities and the implementation of legal reform programmes. After two decades of study, it is not yet clear what institutions have the most impact on economic performance. Also, these studies do not provide an effective roadmap for institution building, which has resulted in limited success of reform efforts: recent stud- 
ies show that $40 \%-60 \%$ of recent attempts at institutional development appear to have had no effect on government effectiveness (Andrews, 2013). Similarly, Thomas Ulen argues that it is not possible to show causality, i.e. direct contribution of law to economic performance, as government power and political will are useful substitutes for a legal system (Ulen, 2011).

Thirdly, there remains a debate as to whether institutions are the pre-requisites for, or result of economic development. Hernando de Soto argues that the legal system is the main differentiator between industrialised and developing countries (De Soto, 1989). He holds that "the law is the most useful and deliberate instrument of change available to people" (De Soto, 1989, p. 187). Conversely, Ha-Joon Chang argues that institutional development will occur in tandem with economic performance: "today, it is widely accepted even by many orthodox economists that policies directly derived from the experiences of the developed countries- or even worse, from economic textbooksare likely to fail in developing countries, where certain institutions whose existence these policies take for granted (e.g., well-defined property rights, a developed government bond market) simply do not exist" (Chang, 2007, p. 2). Furthermore, the rise of China as an economic super-power has diminished the robustness of the proposition that the rule of law and property rights, as advocated by mainstream schools of thought, are necessary to create the conditions for improved economic performance. Julian Du argues that China achieved its impressive economic growth record in absence of adequate legal institutions; China is rated below average on various measurements of rule of law, property rights protection, contracting institutions etc. (Du, 2011). Chang and Du seem to argue that rather than law birthing development, increased wealth will stimulate the emergence of strong institutions, and a modern legal system will be the result of economic development, not a pre-requisite.

Fourthly, IFI-led legal reforms have been criticised for their attempt to recreate features of western legal systems in other economies: discussing the Legal Origins literature, Curtis Milhaupt posits that "the tendency to place great analytical weight on quantifiable but extremely thin legal variables is the major weakness of the law and finance literature" (Milhaupt, 2009, p. 480). In the opinion of Mathias Siems, LLSV "follow the US model, implicitly benchmarking how similar legal systems are to the US one, and whether this makes a difference in terms of financial development" (Siems, 2011, p. 6). This approach is reminiscent of modernisation theory advanced by Rostow in the 1960s, in its encouragement of newly independent countries to imitate western advanced economies in a sequential manner (Rostow, 1960). Riegner (2016, p. 6) suggests that the benchmarks for measuring the quality of laws and institutions imply "normative assumptions and value judgments which decide social conflicts of interest in one direction or the other". Milhaupt argues that legal reform efforts have suffered from poor benchmarking, and the focus should move from "standardisation to functionality, responsiveness and adaptability" (Milhaupt, 2009, p. 844). 
Fifthly, the limitations of the econometric approach of NIE to analysis of laws and legal institutions are well discussed; NIE scholars have been described as economists, who are self-professed 'wannabe lawyers' (Michaels, 2011), and have not paid adequate attention to legal scholarship. Conditionalities and indices of multilateral agencies have been widely criticised; conditionalities have proved contentious, and are challenged for their imposition on the sovereignty of national governments. IFIs seem to flout their own message of good governance and democracy through their insistence on economic and systemic reforms which are not mandated by consent of the citizenry of countries in which they are implemented (See Chapter 2 for discussion on conditionalities). To illustrate, discussing the capacity of the CPIA to influence the economic trajectory of countries, Riegner (2016, p. 14) observes that the questionnaire used is "issued by the bank in an internal procedure that does not, in principle, involve other organs or state representatives. This is based on an interpretation of the Articles of Agreement that grants management the power to conduct the ordinary business of the organisation".

The various schools of thought in the field of law and development present ideal features and typologies of laws and legal institutions to enable improvements in economic performance. These features are indicators used to measure the nature and quality of services which are provided by national legal systems for economic governance, or an argument for the reforms of institutional structures to support the delivery of the objectives of economic development. Legal reform programs were intended to re-engineer economic development, as laws were introduced to assign and supervise functions to institutions, and provide the requisite tools, normative values and professional capacities necessary for good government management of economies. It is not yet evident that these reforms have integrated the values, processes or systemic changes to enable the emergence of legal frameworks which facilitate the achievement of economic objectives in sub-Saharan Africa. However, upon inquiry, it may be the case that laws and legal systems do function and serve as instruments for developmental objectives which have not been considered in mainstream law and economic development discourse. For the purpose of building legal systems which adequately support economic development, it is necessary to properly understand approaches, rationale, and consequences of law-making and institution building in contemporary Africa.

\subsection{Which Way Forward: Law and Economic Development}

This study is based on the premise that laws and legal systems do manage and influence the developmental processes of economies. In this regard, the state, or government is considered the most important institution in the developmental process, as it establishes and enforces the law, policies, conditions and processes for economic activity and social interaction. Chang describes the role of the state as coordination for change, provision of vision, conflict management and institution building (Chang, 1999). The developmental 
trajectory of African economies over the last 60 years suggests that it is necessary not only to explain the effects of legal systems on economic performance, but crucial to understand the ways in which legal systems interact with economic activity.

Laws and legal systems are tools by which governments manage economies; law has been described as a political resource, an object of capture, of evasion or of manipulation alongside customary norms in pluralist regulative systems (Harris-White, 2003). Legal documents, such as constitutions and legislation express development agenda as determined by the state, and institutions are responsible for the implementation of these agenda, and for economic management. The legality of a venture or undertaking is determined by laws, which also determine the prerequisites for participation in economic activity, and establish dispute resolution mechanisms. According to Howard Stein, state economic management strategy and principles are implemented by regulatory systems through state and public entities which are "embedded in even the most rudimentary markets. These entities provide infrastructure, licensing, regulations and an array of related bodies such as the legal and financial systems. These are not simply supporting mechanisms but constructs that are internalized in the operation of markets" (Stein, 2003, p. 161).

For the purpose of this study, i.e., understanding how legal systems interact with institutions and govern economies, there is limited benefit in evaluating the functions of legal systems of African countries against standardised benchmarks, e.g., the Doing Business index; the differences in political and economic contexts necessarily generate divergent functionalities for legal systems. The quantitative method of analysing legal systems is restricted, and has, so far focused on a narrow set of issues, the majority of which have been determined within IFIs.

To avoid the difficulties of selecting an appropriate benchmark, and the restrictions of quantitative evaluation of legal systems, this study will pursue a functionalist approach, in which a hypothetical question may be posed to examine how a problem would be solved in different systems, as suggested by Mathias Siems (Siems, 2011). This method of inquiry assumes the same type of problem exists in all legal systems examined. As recommended by Milhaupt (2009), the case method enables the investigator to disentangle the operation of a complex system by means of systematic inquiry.

Accordingly, this investigation of the relationship between law and economic development in Africa is undertaken through a comparative case-study of Nigeria and Rwanda, in their attempts to reform laws and legal institutions to obtain relief on external debt. Both countries obtained debt relief from international creditors in 2005, on debt obligations acquired in the 1970s and 1980s. Debt relief was predicated on the implementation on reforms of the legal and institutional mechanisms for public finance management. Thus, the evaluation of the relationship between law and economic development will be undertaken through an examination of the approaches to, and outcomes of these reform programs in Nigeria and Rwanda. These programs required the enactment of legislations, as well as the amendment of the functionalities of legal systems and 
public institutions. Furthermore, the effects of legal and institutional reform are tangible and can be subjected to evaluation.

\subsection{Research Questions}

This study will undertake an investigation of the relationship of legal systems and economic development of Nigeria and Rwanda through the following questions;

1. Why did the governments of Nigeria and Rwanda seek and obtain debt relief in 2005?

2. In what ways did the governments of Nigeria and Rwanda deploy laws and institutions as instruments to obtain debt relief?

3. To what extent, have legal reforms contributed to the achievement of the objectives of debt relief?

The purpose of this investigation is to obtain a more nuanced understanding of the nature of the interplay between legal systems, institutions and economic development in different contexts in both countries. The study will present the difficulties and conflicts that arise in attempts to deploy the law towards the function of economic governance, and as an instrument of economic management. The case-study will show the multiplicity and diversity of interpretations of a single legal concept in these two African countries. These divergent interpretations result in peculiar objectives and methodologies of legal reform. Furthermore, this investigation will highlight the gaps which have limited the successes of previous reform efforts, and emphasise the necessity of contextual reform, i.e., design of legal interventions to suit specific economic systems, objectives, and capacities.

\subsection{Chapter Outline}

In addition to this introduction this thesis consists of five chapters (2-6) of which the main objectives can be summarized as follows:

\section{The Context of Debt Relief}

This chapter states the objectives of the Governments of Nigeria and Rwanda in seeking debt relief in 2005, as it provides a detailed overview of the economic and institutional arrangements which allowed the acquisition and escalation of public debt by the governments of both countries. The nexus of laws/legal systems and institutions for economic management are presented through case studies of the policies and operations 
of governments and IFIs. Furthermore, the contractual agreements between the governments and creditors are outlined, as well as the various arguments put forward for debt relief. The chapter also undertakes an analysis of the relationship between laws, institutions and economic development.

\section{Reforms for Debt Relief}

Through case studies, the reforms implemented by IFIs and governments towards public debt management are examined. This chapter discusses the mechanisms by which Nigeria and Rwanda obtained debt relief, i.e., the implementation of programs to restructure their economies, as well as legal reforms. Budgetary legislations- the Fiscal Responsibility Act 2007 in Nigeria, and the Law on State Finances and Property 2013 in Rwanda, introduced to regulate government management of public debt are presented. An analysis of the provisions of these legal instruments in undertaken to extract the intended objectives of legal reform. Also, the dynamic interactions of law and institutions of government are outlined.

\section{Reform Effectiveness: Laws to Regulate Government Management of Public Debt and Foster Debt Sustainability}

This chapter interrogates the usefulness of law as an instrument for economic development through an investigation of the effectiveness of legal reforms in Nigeria and Rwanda. Two questions guide this investigation, i.e., 1) do the debt management provisions of budgetary legislations regulate government behaviour? 2) To what extent does regulation (by laws) of government behaviour contribute to the sustainability of public debt? Laws introduced accounting, predictability and monitoring of public debt portfolios. However, these have not addressed the utilisation of debt finance, or prevented the accumulation of heavy debt portfolios in both countries. Additionally, the chapter addresses the benchmarking of legal reforms, even as it discusses the ideological basis of reforms, i.e., the governance agenda of NIE, as it has influenced the policies of IFIs, which maintain an emphasis on 'correct' macroeconomic policies and quantitative indicators of development.

\section{Discussion: Laws, Institutions and Economic Development}

The dimensions of law as an instrument of economic development are presented; budgetary legislations serve as mental constructs which determine the approach of government to the management of public debt. Also, the laws are the terms of reference for the functions of government institutions, even as they reshape political economy of relationships and power structures. This chapter presents the contributions of this thesis to the field of law and development through an evaluation of its findings 
against the criticisms of the NIE-influenced approach to legal and institutional reforms. In addition, the chapter presents propositions to render 'generic' legal reforms more suitable to the contextual needs and challenges of developing countries. Furthermore, the chapter discusses the opportunities for refinements to the operation of budgetary legislations in Nigeria and Rwanda.

\section{Conclusion}

This chapter ends the study with a restatement of findings and contributions of the thesis. The intellectual and geographical limitations of the study are presented, even as potential opportunities for future research are explored.

\subsection{Contribution of Study to Field of Law and Development}

The investigation is categorised into three chronological periods; firstly, the accumulation of public debt between the 1970s and 1980s, secondly, the campaign for debt relief in the 1990s-2000s, and thirdly, post-debt relief era of 2005 to 2015. In each period, the investigation covers four thematic areas, namely:

- The nexus of law, institutions, governance and economic development;

- Governance: the role of the state in economic development;

- The dimensions and dynamics of law as an instrument of national economic development; and

- External debt: relationships between creditors and debtors, legal dimensions and instruments which underpin public borrowing and debt relief.

The interaction and interplay of laws and institutions is considered through an examination of the ways that governments respond to obligations arising from budgetary legislation between 2005 and 2015. This examination yields the argument that legal reforms can be made relevant, suitable and effective to contexts if they are:

1) Concerned with, directed to, and measured by the achievement of outcomes of economic development within countries and;

2) Evaluated through the behaviours and practices of institutions, and the effect of these on the economy.

These propositions are explored through the case-studies in chapters 2-4, and discussed in chapter 5 . 


\subsection{Importance of Study}

Legal reforms are often prescribed as interventions, which, when inserted, will correct anomalies in economic systems, and unlock the solutions- behaviours, resources, and institutional functions which lead to economic development. Measurements and comparative evaluations of the quality of laws and legal systems influence the adoption of 'ideal' laws and legal interventions to trigger improvements in economies.

In the context of debt obligations acquired by governments, i.e., public debt, many African countries continue to accumulate debt burdens, despite budgetary legislation to regulate government management of debt portfolios. Typical economic measurements of economic health and debt sustainability consider the size of national debts compared to GDP. In this sense, the level of debt obligations is calculated as a percentage of the entire output of the country's economy (Organisation for Economic Cooperation and Development, 2016). According to the World Bank, in 2015, the debt to GDP ratios of Japan and the United States of America, two of the largest economies globally, stood at 198\% and 97\%, respectively (World Bank, 2017).

Government borrowing is not necessarily problematic. Indeed, it can be reasonably expected that governments of developing economies will borrow to finance undertakings and investments to improve economic performance and social services. The problem, as has been experienced by many African countries, is that high levels of borrowing create obligations on current and expected financial resources, without the delivery of tangible economic and social benefits for the population. Crucially, it often is the case that African countries are unable to repay debts: as a result of debt burdens which were acquired in the 1970s and 1980s, 35 African countries implemented the IMF and World Bank debt relief mechanism, i.e., the Poverty Reduction Strategy Paper (PRSP) process between 2000 and 2014. This process typically stipulated the introduction of reforms to manage public finances, often underpinned by legislation (International Monetary Fund, 2016). Through the PRSP process, economic, institutional and legal reforms were adopted by these countries seeking debt relief. Also, PRSPs incorporated evaluations of parliamentary systems, in order to identify opportunities for legislation to underpin reforms, and integrate legislative supervision of implementation of reforms and programs (Hubli \& Mandaville, 2004). Furthermore, assessments of 'good' debt policy on the CPIA index consider the extent to which "debt management strategy is conducive to minimising budgetary risks and ensuring long-term debt sustainability" (World Bank, 2016). This approach measures debt sustainability against 'ideal' policy frameworks, and does not necessarily look to the utilisation of debt finance for national development. Thus, it is necessary to reconsider the 'institutional' approach to law as a tool for economic development. Also, the dynamic interaction of law and institutions should be better understood to conceptualise and frame laws for effectiveness.

In summary, how can law contribute to the economic development of the African continent? How does law work, what effect has it had on economic performance, and 
how can it be further formulated towards the achievement of economic objectives? Chapter 2 commences this investigation with a presentation of the context of debt relief obtained by Nigeria and Rwanda in 2005. 

Chapter

The Context of Debt Relief 
Debt relief (debt forgiveness or debt cancellation) is rooted in the idea that obligations to creditors should not require borrower countries to make extreme sacrifices (Moss, et al., 2004). When the debtor is unable to service obligations without the sacrifice of basic living standards, it becomes necessary to re-evaluate the terms of the original transaction, payment arrangements, as well as the debtor's circumstances. In the context of international law, debt relief is underpinned by the premise that a primary obligation of governments and international financial institutions is the delivery of developmental outcomes.

This chapter address the first question of this research project, i.e., why did the Governments of Nigeria and Rwanda seek and obtain debt relief in 2005? These objectives were two-fold; firstly, to remove huge debt burdens, and secondly, to rectify the institutional weaknesses which had allowed the accumulation of public debt owed to international creditors. The relationship between laws and institutions, as well as their functions for the purpose of economic management is presented through a comparative study of Nigeria and Rwanda. Several observations are highlighted through this study; firstly, governments express the agenda of economic development through legal instruments. However, legal instruments are amenable to the purpose of government, and as such, the objectives of economic development are of greater importance than the form of legal system or institutions. Furthermore, the nexus of legal systems, institutions and economic performance is critical for the management of economic development- laws and regulations are implemented by institutions, which require sufficient power and capacity to function for purpose. Finally, institutions are created, and function within specific political, social, economic and cultural contexts. Thus, the peculiarities of the environments in which institutions function must be accounted for in the design of reform programs.

In 2005, Nigeria and Rwanda obtained relief from creditors for public debt which had accrued from the 1970s and 1980s. Both countries implemented significant legal and institutional reforms to substantiate their arguments that amounts previously spent on servicing debts would be redirected towards national development. This chapter presents the economic and policy positions, at national and international level, which enabled the rapid escalation of the debt portfolios of Nigeria and Rwanda. Thereafter, the ideological and institutional changes which enabled Nigeria and Rwanda to obtain significant debt relief from private, government and institutional creditors in 2005 are outlined. Finally, the chapter examines the relationship between legal systems and economic management at national and institutional levels. 


\subsection{The Context of Debt Relief in $\mathbf{2 0 0 5}$}

In the 1970s, the sale of commodities on international markets formed the principal source of revenue for many African Governments, including the Governments of Nigeria and Rwanda. In 1980, the Lagos Plan of Action, adopted by the Organization of African Unity (OAU), noted that African economies were over-dependent on the export of basic raw materials and minerals. It followed that African countries were 'extremely susceptible' to external factors, with the resultant deleterious effects on economic stability (Organisation of African Unity, 1980). This economic model found its origins in the extractive institutional and economic systems which were operated during the colonial era (Acemoglu \& Robinson, 2012; Acemoglu, et al., 2001). During the same period, state-led industrialization and government management of the economy were the preferred strategies for driving economic development (Okonjo-Iweala, 2012; See 1.2.2.). The Governments of Nigeria and Rwanda established public enterprises in almost every sector, and managed the economy through subsidies, price controls and commodity boards. This expansion of the state was aided by high commodity prices on the international market, which delivered high levels of income for the governments of commodity exporting countries. Nigeria was a crude oil exporter, and Rwanda an exporter of coffee and tea. However, following the crash in commodity prices in the late 1970s, both Nigeria and Rwanda experienced severe economic contractions, and sought international assistance, by way of credit facilities from commercial, government and institutional creditors to sustain government spending. From the late 1970s, Nigeria and Rwanda amassed significant debt profiles, which impacted upon their political, economic and social arrangements, as well as developmental outcomes. While the larger share of Nigeria's debts was owed to the Paris Club of Creditors, the majority of Rwanda's obligations was owed to International Finance Institutions (IFIs).

Towards the end of the 1990s, the alignment of several schools thought caused emphatic changes in international development discourse and policy. Firstly, despite nearly two decades of direct interventions by the World Bank and International Monetary Fund (IMF) into the governance structures of developing countries through economic and institutional reforms, the majority of African countries continued to perform poorly on economic and governance indices. Indeed, it appeared that these interventions had enabled unfavourable outcomes, such as social dislocations, higher rates of poverty and unemployment, as well as weak economic growth. These outcomes called into question the usefulness and veracity of these reform programmes. Secondly, the Jubilee 2000 debt campaign attributed poor economic performance to the unsustainable terms upon which loans had been provided to borrower developing countries. This campaign provided the intellectual and emotional arguments for debt relief, and contributed to the rise of the global development movement. 
In 2005, Nigeria obtained debt relief from the Paris Club, while Rwanda obtained debt relief from IFIs. The next section outlines the international financial organisations and institutions to which the governments of Nigeria and Rwanda were indebted.

\subsubsection{Creditor Institutions and Organisations}

The institutional structures for the management of international economic relations were established in the closing stages of the Second World War (1939-1945). This period was characterised by profound changes in international political and economic systems; empires disintegrated, and new nation-states emerged globally. The war was preceded by intense economic protectionism and political rivalry which escalated into military conflict. The Allied Powers, i.e., the western countries which won the War, became the architects of the post-war era. These countries pursued an agenda of international cooperation, and established institutions to manage international political and economic relations. Also, the winning countries were concerned with the repair and rebuilding of the economies and infrastructure of several of those states which had been battered during the war. Thus, in 1944, the United Nations Monetary and Economic Conference, or the Bretton Woods Agreement established the World Bank, and the IMF as international financial institutions to manage the new international economic and monetary systems. The World Bank Group and the IMF were instituted on the basis of shareholder membership (International Monetary Fund, 2017), in which countries gain voting power in proportion to the quantum of shares acquired (Bretton Woods Project, 2016). Shares and voting power were allocated based on the computation of the economic strength of member countries. As a result, western industrialised countries held the greater proportion of shares; at inception, the United States of America alone held 35 per cent of stock in the World Bank (Griffith-Jones, 2002). However, as at 2015, reforms within the World Bank Group and the IMF have assigned greater shares and voting powers to Developing and Transition countries, which now hold 47.24 per cent of stock in the World Bank (World Bank Group, 2015).

Over the last seventy years, the World Bank and IMF have evolved into the two largest international creditor institutions globally, and have amassed a repository of intellectual resources, alongside an armoury of economic resources. Thus, they have shaped the emergence of what may be termed the practice of development finance, as they spearhead the formulation and execution of international development policy, and dominate the development discourse.

\subsubsection{The World Bank Group}

The Bank expanded after 1944, and now comprises five institutions, of which the International Bank for Reconstruction and Development (IBRD) and the International Development Association (IDA), form the World Bank (World Bank, 2017). The IBRD provides 
loans and development assistance to middle-income countries and creditworthy lowerincome countries, as well as loans to borrowers guaranteed by member countries. The IDA provides low-interest loans and other services to the poorest countries. Private sector engagements are led by the International Finance Corporation (IFC) which finances private sector ventures in developing countries, in partnership with private investors. The Multilateral Investment Guarantee Agency (MIGA) provides guarantees against non-commercial risk to foreign investors. The International Centre for the Settlement of Investment Disputes (ICSID) is a facility for dispute resolution for international investment (World Bank, 2001). The table below presents the lending and operations of the World Bank Group.

Table 1: The World Bank Group Lending and Operations

\begin{tabular}{|c|c|c|}
\hline \multicolumn{3}{|l|}{ The World Bank Group } \\
\hline \multicolumn{3}{|c|}{ Engagements with Governments of Member Countries and Private Sector } \\
\hline \multicolumn{3}{|c|}{$\begin{array}{l}\text { Sources of Finance } \\
\text { - IBRD: Income from Loan Repayments, Investments (World Bank, 2014) } \\
\text { - IDA: Contributions from Donor Members Countries, the IBRD and the IFC (World Bank, n.d.) }\end{array}$} \\
\hline \multirow{10}{*}{$\begin{array}{l}\text { 1. Financial } \\
\text { Instruments (World } \\
\text { Bank, 2015) }\end{array}$} & \multicolumn{2}{|l|}{ IBRD Loans } \\
\hline & Front-end fee: & $1.00 \%$ of the loan amount, payable upon loan effectiveness. \\
\hline & Lending rate: & Product and Currency-Specific \\
\hline & $\begin{array}{l}\text { Commitment } \\
\text { fee: }\end{array}$ & $\begin{array}{l}0.85 \% \text { in the first four years, on undisbursed } 0.75 \% \text { thereafter. } \\
\text { balance: for other loans: } 0.75 \% \text {. for all loans: a partial waiver may } \\
\text { apply. }\end{array}$ \\
\hline & Interest waiver: & $\begin{array}{l}\text { Partial waivers can be applied on disbursed and outstanding loan } \\
\text { balances for those borrowers which service obligations as required. }\end{array}$ \\
\hline & Maturity: & Up to 25 years, including a grace period. \\
\hline & \multicolumn{2}{|l|}{ IDA Credits } \\
\hline & Service charge: & $0.75 \%$ \\
\hline & $\begin{array}{l}\text { Commitment } \\
\text { fee: }\end{array}$ & $0.0-0.5 \%$ on undisbursed balance \\
\hline & Maturity: & $\begin{array}{l}40 \text { years } \\
35 \text { years for countries that receive a combination of IDA credits and } \\
\text { IBRD loans, with a 10-year grace period. }\end{array}$ \\
\hline Facility & \multicolumn{2}{|l|}{ Modalities } \\
\hline \multirow{3}{*}{$\begin{array}{l}\text { 2. Investment Project } \\
\text { Financing } \\
\text { IBRD Loan, IDA } \\
\text { Credit/Grant and } \\
\text { Credit Guarantee to } \\
\text { Governments }\end{array}$} & $\begin{array}{l}\text { Specific } \\
\text { Investment } \\
\text { Financing }\end{array}$ & $\begin{array}{l}\text { Support for the technical, financial, economic, environmental, and } \\
\text { institutional viability of a specific investment. Also, support for policy } \\
\text { reform in the area of investments. }\end{array}$ \\
\hline & $\begin{array}{l}\text { Sector } \\
\text { Investment and } \\
\text { Maintenance } \\
\text { Loan }\end{array}$ & $\begin{array}{l}\text { Support for public expenditure programs in particular sectors, and } \\
\text { institutional capacity development for the management of } \\
\text { investment program. }\end{array}$ \\
\hline & $\begin{array}{l}\text { Adaptable } \\
\text { Program Loan }\end{array}$ & $\begin{array}{l}\text { Support (phased) for long-term development programs. Loan } \\
\text { disbursement is accompanied by review of outcomes of previous } \\
\text { disbursements. }\end{array}$ \\
\hline
\end{tabular}




\begin{tabular}{|c|c|c|}
\hline & $\begin{array}{l}\text { Learning and } \\
\text { Innovation Loan }\end{array}$ & $\begin{array}{l}\text { Support for small pilot-type investment and capacity-building } \\
\text { projects. Maximum amount is US\$5 million, into which is integrated } \\
\text { effective monitoring and evaluation systems over a period of } 2-3 \\
\text { years. }\end{array}$ \\
\hline & $\begin{array}{l}\text { Structural } \\
\text { Adjustment Loan }\end{array}$ & $\begin{array}{l}\text { Support for macroeconomic reforms that promote growth, efficient } \\
\text { use of resources, and sustainable balance of payments over the } \\
\text { medium and long term. }\end{array}$ \\
\hline & $\begin{array}{l}\text { Special } \\
\text { Structural } \\
\text { Adjustment Loan }\end{array}$ & $\begin{array}{l}\text { Support for structural and social reforms undertaken by } \\
\text { creditworthy borrowers faced with crisis and exceptional external } \\
\text { financing needs. Contingent upon an existing IMF program, and } \\
\text { usually part of an international support package of multilateral } \\
\text { donors, bilateral donors, and private lenders and investors. } \\
\text { - 5-year maturity period with a 3-year grace period } \\
\text { - No waivers of interest or commitment charges }\end{array}$ \\
\hline \multirow{5}{*}{$\begin{array}{l}\text { 3. Development Policy } \\
\text { Financing } \\
\text { IBRD loan, IDA } \\
\text { Credit/Grant and } \\
\text { Guarantee Budget } \\
\text { Support Program for } \\
\text { Policy or Institutional } \\
\text { Action }\end{array}$} & $\begin{array}{l}\text { Technical } \\
\text { Assistance Loan }\end{array}$ & $\begin{array}{l}\text { Support to build institutional capacity in the borrower country. } \\
\text { Technical Assistance Loans are contingent on specific action } \\
\text { programs to build organizational strength, and on terms of reference } \\
\text { for the appointment of consultants and local counterparts. }\end{array}$ \\
\hline & $\begin{array}{l}\text { Sector } \\
\text { Adjustment Loan }\end{array}$ & $\begin{array}{l}\text { Support for policy changes and institutional reforms in a specific } \\
\text { sector concerned with the incentive and regulatory frameworks for } \\
\text { private sector development, institutional capability, and sector } \\
\text { expenditure programs }\end{array}$ \\
\hline & $\begin{array}{l}\text { Programmatic } \\
\text { Structural } \\
\text { Adjustment Loan }\end{array}$ & $\begin{array}{l}\text { Support for multiyear framework of phased medium-term } \\
\text { government program of policy reforms and institution building. } \\
\text { - } 3 \text { to 5year period, with annual disbursements tied to specific } \\
\text { targets and indicators. } \\
\text { - Guided by analytic and advisory work, loans are blended with } \\
\text { capacity building and public sector reform programs in the areas } \\
\text { of expenditure management, governance resource allocation, and } \\
\text { public service delivery. }\end{array}$ \\
\hline & $\begin{array}{l}\text { Rehabilitation } \\
\text { Loan }\end{array}$ & $\begin{array}{l}\text { Support for government policy and macroeconomic reform } \\
\text { programs aimed at creating an environment conducive to private } \\
\text { sector investment. Commonly used in transition economies and } \\
\text { post-conflict situations, where the structural reform agenda has not } \\
\text { been determined. }\end{array}$ \\
\hline & $\begin{array}{l}\text { Debt Reduction } \\
\text { Loan }\end{array}$ & $\begin{array}{l}\text { Assistance to eligible highly indebted countries for the reduction of } \\
\text { reduce commercial debt and debt service in the context of a } \\
\text { medium-term financing plan in support of sustainable growth. } \\
\text { Often utilised alongside adjustment loans. }\end{array}$ \\
\hline $\begin{array}{l}\text { 4. Programs for } \\
\text { Results }\end{array}$ & \multicolumn{2}{|c|}{$\begin{array}{l}\text { Disbursement of Funds linked to delivery of results in country-designed and implement } \\
\text { programs }\end{array}$} \\
\hline $\begin{array}{l}\text { 5. Trust Funds and } \\
\text { Grants }\end{array}$ & \multicolumn{2}{|c|}{$\begin{array}{l}\text { - Immediate assistance in crises } \\
\text { - Situations in which lending ability is limited } \\
\text { - Pilot innovations }\end{array}$} \\
\hline
\end{tabular}


6. Private Sector Options

The International Finance Corporation (International Finance Corporation, n.d.) Loans to companies, intermediary banks and financial institutions for 7 to 12 years Equity: $5 \%$ to $20 \%$ equity stake in companies or private equity funds Trade and Supply Chain Finance: risk mitigation on transaction basis for banks Syndications: capital mobilization for private sector projects Treasury Client Solutions: provides companies with long term currency solutions and facilitation to capital market Venture Capital: early and late stage venture financing through direct investments and funds

Advisory: technical and financing knowledge, expertise and tools

Asset management: connecting investors with investment opportunities globally (IFC Asset Management Company, n.d.)

7. Technical Assistance

- Technical Assistance: professional technical advice to support reforms

- Reimbursable Advisory Services

- Economic and Sector Work: data collection and evaluation in collaboration with governments

- Business Advice

- Donor Aid Coordination for regular interaction between multiple donor groups (World Bank, 2015)

\subsubsection{The International Monetary Fund}

The IMF was established as a permanent institution to promote international monetary cooperation, the growth and expansion of balanced international trade, promote exchange stability, to assist in the establishment of a multilateral system of payments between members and the elimination of foreign exchange restrictions, and to give confidence to members through the provision of general resources to correct maladjustments in their balance of payments (International Monetary Fund, 1944). These objectives are to "shorten the duration and lessen the degree of disequilibrium in the international balances of payments of members" (ibid). The table below presents the institutional overview of the IMF. 
Table 2: $\quad$ IMF Lending and Operations

The International Monetary Fund

Engagements with Governments of Member Countries only

(Article V, Section 1, Articles of Agreement, International Monetary Fund, 1944)

Sources of Finance:

- Shareholder subscriptions, Loan Repayments, and Income from Investments

- Borrowing from member countries through General Arrangements to Borrow and New Arrangements to Borrow (International Monetary Fund, 2016)

Financial Instruments: Non-Concessional and Concessional Loans to member states experiencing Balance of Payments Problems (International Monetary Fund, 2016)

1. Non-Concessional Loans at market-related interest rates, and large loans subject to surcharges

Facility

Standby Arrangements

Flexible Credit Line (countries with strong fundamentals, policy and implementation)

Precautionary and Liquidity Line (countries with strong fundamentals, policy and implementation)

Extended Fund Facility

Rapid Financing Instrument
Modalities

- 12-24month Disbursement Period to address Short-term Balance of Payments Problems

- Conditionality-Based

- Repayment over $3 \frac{1}{4}$ to 5 years

- 1-2year Disbursement Period

- Not based on Conditionality

- Repayment over $3 \frac{1}{4}$ to $5 y e a r s$

- 6 months to 2-year disbursement duration. Loan to address Moderate Vulnerabilities

- Qualification and Conditionality-Based

- Repayment over $3 \frac{1}{4}$ to 5 years

- 3-4year disbursement duration. Loan to address Medium to Long Term Balance of Payments Problems

- Conditionality-Based. Contingent on Implementation of Reforms

- Repayment over $4 \frac{1}{2}$ to 10 years

- Emergency Assistance to address Urgent Balance of Payments Problems

- Conditionality Based

2. Concessional Lending to Low Income Countries to support efforts towards achieving macroeconomic standing which enables poverty reduction and growth

Facility

Extended Credit Facility

Standby Credit Facility

Rapid Credit Facility
Modalities

- Medium Term Support to tackle Protracted Balance of Payments Problems

- $0 \%$ interest rate

- $5 \frac{1}{2}$ year grace period

- 10year maturity period

- Short-Term of Potential Balance of Payments Problems

- $0 \%$ interest rate

- 4year grace period

- 8year maturity period

- Intervention to address Urgent Balance of Payments Problems

- Conditionality Based

- $51 / 2$ year grace period

- 10year maturity period 


\subsubsection{The African Development Bank Group}

In the 1960s, after the first wave of independence in Africa, the dominant political sentiment was that of self-actualization and self-determination. At international and national levels, economic management was concerned with ownership, and government control over economic systems (See 1.2.2). These sentiments and policies are echoed through instruments such as the 1962 United Nations Resolution on the Permanent Sovereignty over National Resources. During this period, African political leaders spoke to the necessity of African-led development. In furtherance of this objective, the African Development Bank (AfDB) was founded in 1964 to promote economic development and social progress of the African continent, through the provision of financial resources, policy advice and technical assistance to regional member countries. The Group comprises the African Development Bank, the African Development Fund which disburses concessional loans to countries, and the Nigeria Trust Fund, which disburses concessional financing to projects undertaken by the poorest countries. The AfDB Group is instituted on a membership-shareholding basis by 54 African countries and 27 nonAfrican countries. The institutional overview is outlined below in the table below.

Table 3: Institutional Overview and Lending Operations of the African Development Bank Group

\begin{tabular}{|c|c|c|}
\hline \multicolumn{3}{|c|}{ The African Development Bank Group } \\
\hline \multicolumn{3}{|c|}{ Finance and Technical Support to Governments, Private Sector and Development Institutions } \\
\hline Funding Sources & \multicolumn{2}{|c|}{$\begin{array}{l}\text { - Shareholder Subscriptions } \\
\text { - Loan Repayments } \\
\text { - Borrowing on International Markets } \\
\text { - Income from Investments } \\
\text { (African Development Bank Group, 2011) } \\
\text { - Capital Increases by the African Development Fund and the Nigerian Trust Fund } \\
\text { (African Development Bank Group, n.d.) }\end{array}$} \\
\hline \multicolumn{3}{|c|}{ Financing Instruments (African Development Bank Group, n.d.) } \\
\hline \multirow[t]{3}{*}{ Loans } & - Senior Debt: & $\begin{array}{l}\text { - Up to } 20 \text { years ( } 5 \text { years' grace period). } \\
\text { - Foreign or local currencies, risk priced }\end{array}$ \\
\hline & - Guarantees & $\begin{array}{l}\text { - Partial risk, partial credit (long tenors) } \\
\text { - For specific credits or commercial bank SME programs, risk } \\
\text { priced. }\end{array}$ \\
\hline & - Subordinated Debt & $\begin{array}{l}\text { - Subordinated loans or bonds. } \\
\text { - Local currency possible, maximum } 15 \text { years }(10+5) \text {, risk priced }\end{array}$ \\
\hline Equity & \multicolumn{2}{|c|}{$\begin{array}{l}\text { - Direct investments in banks, development financial institutions (DFIs), micro-finance } \\
\text { institutions, etc. } \\
\text { - Up to } 25 \text { per cent with or without Board seat, planned exit, commercial returns }\end{array}$} \\
\hline Technical Assistance & \multicolumn{2}{|c|}{$\begin{array}{l}\text { - Grants for studies } \\
\text { - Up to US } \$ 1 \text { million for institutional capacity building programs }\end{array}$} \\
\hline
\end{tabular}




\subsection{Economic Policy Reforms}

From the late 1970s, Nigeria and Rwanda amassed huge debt burdens which occurred within the framework of global economic trends; in 1973, the Organisation of Petroleum Exporting Countries (OPEC) increased the price of crude oil on the international market (Fattouh, 2007). Increases in the price of oil caused pressures in industrialised countries, and a period of economic boom for oil-rich developing countries, such as Nigeria. Excess funds and savings obtained from the sale of oil were domiciled in banks in western countries, which in turn offered credit to developing countries on variable or floating interest rates. Interest rates began to rise in 1979, which increased the amounts borrower countries required to service loans (Cline, 1983). Furthermore, in response to the oil shocks, and economic recessions which followed, industrialised countries had imposed monetary policies, which led to crashes in the price of primary goods sold by non-oil developing countries. To manage the losses in revenue brought about by the combination of higher payments required for debt servicing and lower prices of primary goods on the international market, developing countries resorted to further borrowings from IFIs and industrialised countries. A debt crisis erupted in 1982 when Mexico, followed by other countries stopped servicing their debt obligations. To manage the crisis, the IMF led the institutional response directed at solving the crisis (Forum on Debt and Development, 1992).

An important part of crisis management was the identification of the factors, such as policy and institutional weaknesses which allowed the deep impact of external shocks on borrower countries, and limited their ability to service debt obligations. The World Bank in 1989 reported that "we have come to appreciate that fundamental structural change is needed to transform African economies and make them competitive in an increasingly competitive world. The adjustment efforts must be continued, and the reforms broadened and deepened. The journey will be long and difficult, and special measures are needed to alleviate poverty and protect the vulnerable" (World Bank, 1989, p. xi). The report attributed economic problems in Africa to poor governance, specifically the failure of public institutions. The Bank further stated that private sector and market mechanism must be supported by efficient public service systems, reliable judicial systems, and accountable administrations (World Bank, 1989).

To rectify economic problems, the IMF recommended reforms commonly known as Structural Adjustment Programmes (SAPs). According to the World Bank, these programs "consist of policy reforms aimed both at stabilizing the macro economy to bring aggregate demand more in line with available resources and at eliminating the gaps between prices and social marginal costs at the sectoral level" (World Bank, 1992, p. 8). In substance, SAPs were policy and institutional reforms intended to correct the structural weaknesses of the economies of borrower countries. Williamson (1990) identifies ten 'standard' policy prescriptions which the Washington Consensus, i.e., the World Bank and International Monetary Fund, considered to be necessary for economic re- 
form; fiscal discipline, streamlined public expenditure, increased tax revenue, marketdetermined interest rates, competitive exchange rates, import liberalization, foreign direct investment and privatization, deregulation and property rights. These prescriptions were directed towards the reduction of state participation in the economy, and the creation of an economic environment in which the private sector would lead economic growth. The role of the state was confined to regulation and supervision.

Following the debt crisis of the early 1980s, Nigeria and Rwanda both implemented SAPs led by the IMF and World Bank. The SAPs, their effects on economic performance, and impact on debt profiles of both countries are outlined in the next section.

\subsubsection{Structural Adjustment Programs in Nigeria}

Nigeria, an oil producing and exporting country, benefited from the increase of the price of petroleum products by the OPEC in the 1970s. The regulatory structure governing the oil sector placed the Central Government and the National Oil Corporation, a government agency, as the legitimate authorities able to engage in international oil trade at all segments of the value chain. It followed that during the 'oil boom' of the 1970s, government receipts from sale of petroleum products grew exponentially. This period of heightened prosperity was immediately followed by a sharp economic downturn in the 1980s. Nigeria's National Centre for Economic Management and Administration explains the economic downturn of the 1980s thus:

"the economic policy orientation during the 1970s left the country ill prepared for the eventual collapse of oil prices in the first half of the 1980s. Public investment was concentrated in costly, and often inappropriate, infrastructure projects with questionable rates of return and sizable recurrent cost implications, while the agricultural sector was largely neglected. Nigeria's industrial policy was inward-looking, with a heavy emphasis on protection and government controls, which bred an uncompetitive manufacturing sector" (National Centre for Economic Management \& Administration, 2004, p. 3).

Politically, the 1970s were characterised by the end of the three-year civil war in 1970, a military coup which ousted General Gowon and ushered in Brigadier General Murtala Muhammed as Head of State in 1975. In 1976, General Muhammed was killed in an attempted coup by Lieutenant Colonel Dimka, General Obasanjo became the Head of State, and then transferred power to a civilian administration led by President Shehu Shagari in 1979. The first coup of the 1980s was led by Major General Buhari who toppled President Shagari and seized power through a coup in 1983. His administration was truncated by another coup led by Major General Babangida in 1985. It was during the period of political turbulence, particularly between 1978 and 1982 that the first wave of significant external debt obligations was obtained, mostly from the International Capital Market. 
The Central Bank of Nigeria reports that "between 1971 and 1981, Nigeria witnessed the era of big borrowing. Loans were acquired by various tiers of government, as Nigeria embarked on major development and reconstruction projects in the aftermath of the civil war. The borrowing continued as the Federal Government embarked on guaranteeing many unviable loans taken by Private Banks, State Governments and Parastatals" (Okoro, 2013, p. 8). In a bid to manage the country's debt profile, the Federal (Military) Government, through Decree 30 of 1978 lifted the ceiling for its external borrowing from N1.0 billion, and capped it at N5.0billion (Ijeoma, 2013). However, this ceiling was often ignored, and did not limit the ability of State Governments to seek and obtain external loans guaranteed by the Federal Government. Two 'jumbo loans' totalling US\$1.75 billion dollars were incurred in 1978. By 1983, up to 90 or so new loans had been procured, 22 by the Obasanjo military regime, 59 by the Shagari civilian administration and 8 by Buhari military regime (Aluko, 2001). The table below shows the number of loans obtained by successive Nigerian Governments between 1975 and 1982.

Table 4: $\quad$ Nigerian Government Borrowing 1975-1985

\begin{tabular}{lll}
\hline Period & Type of Administration & Number of Loans \\
\hline $1975-1979$ & Military & 22 \\
$1979-1983$ & Civilian & 59 \\
$1983-1985$ & Military & 8 \\
\hline
\end{tabular}

The fall in global oil prices in the early 1980s severely reduced government revenue, and by extension government spending. Also, the country's debt profile had risen significantly. The Debt Management Office Nigeria summarises the escalation of Nigeria's debt profile by 1985 :

"The debt stock therefore increased with leaps and jumps, even when no new loans were contracted. Nigeria's external debt stock till 1977 was less than US\$0.8 billion. Beginning from 1978, the external debt stock began to grow astronomically, rising from US\$0.763 billion in 1977 to US\$5.09 billion in 1978 and U\$8.855 billion in 1980, an increase of over 73.96 per cent between 1978 and 1980. By 1985 the debt profile had deteriorated seriously due to persistent inability of the country to meet its external debt service obligations. This resulted in mounting arrears and unmanageable growth of the debt stock relative to available resources. The external debt stock, which was about US\$8.855 billion in 1980 , grew to nearly US\$19 billion by 1985 . Correspondingly, the debt stock as a percentage of total export earnings and GDP rose to uncomfortable levels of $154 \%$ and $24 \%$, respectively. In that year, the debt service payment due was a little above US\$4 billion, which was about 33\% of the total export earnings. However, the actual debt service payment for the year was about US\$1.5 billion." (Debt Management Office, n.d.). 
The figure below presents the increase in Nigeria's external debt stock between 1977 and 1985:

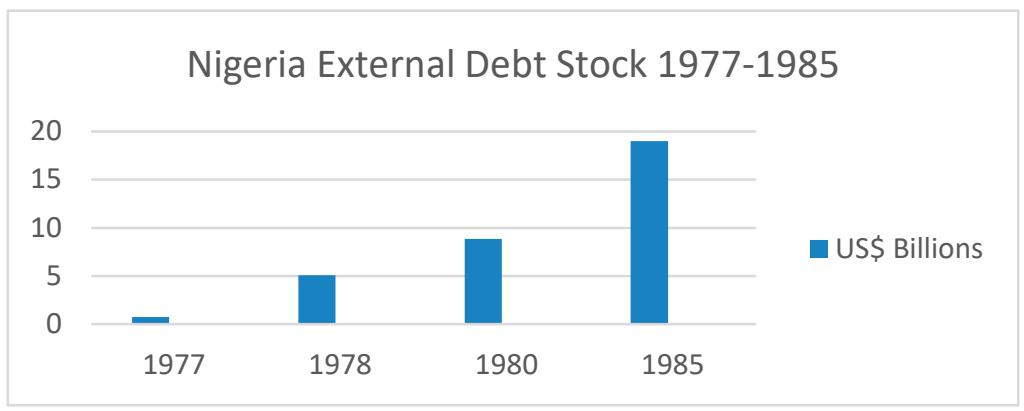

Figure 1: Nigeria's External Debt Stock 1977-1985

In 1984, Nigeria's projected income stood at US\$10billion, 95 per cent of which was to be realised from the sale of oil. In the same year, it was estimated that up to US\$5.5billion was to be spent on the servicing of external debts (May, 1984). The Government had hoped to reschedule debts owed to IFIs, particularly US\$2billion owed to the IMF, and a US\$300million Structural Adjustment Loan taken from the World Bank (ibid). Also, in 1983, the Shagari administration had applied to the IMF for a bridging loan of US\$2.5billion (Agbese, 2016). The conditions attached to the loan by the IMF were negotiated by the Shagari administration, the Buhari regime (1983-1985) and the Babangida regime from 1985. However, by 1986, following worsening economic conditions, and the refusal of creditors to open new credit lines for imports, the Babangida regime convened a public debate to discuss the terms of the IMF facility. This IMF loan was vehemently rejected by labour unions, as well as student and professional groups. Nonetheless, in view of economic contractions, the Government was compelled to adopt a SAP, which was a condition for a World Bank/IMF loan (Omame, 2016). Government revenue had dropped from 24 per cent to 12 per cent of GDP between 1980 and 1985. Also, this period witnessed increased political and social discontent, caused by economic hardship. The Government was faced with three options: (i) to maintain the status quo, i.e., austerity without structural reforms, (ii) accept the IMF loan with its conditions, or (iii) reject the IMF loan and prosecute a SAP designed and implemented by Nigerians (National Centre for Economic Management \& Administration, 2004). In the end, the Babangida administration adopted an IMF SAP in July 1986 (Anyanwu, 1992). This SAP, originally intended to last for two years, was supported by a World Bank US\$450million trade policy and export diversification loan (National Centre for Economic Management \& Administration, 2004).

It has been argued that the Babangida regime adopted the SAP from a desire to redress the external debt crisis of the country (Nwagbara, 2011). According to the World Bank, the objective of the SAP programme of 1986 was "to help promote economic 
efficiency and private sector development as a basis for improving prospects for longterm growth" (World Bank, 1994, p. vii). The SAP implemented by Nigeria combined exchange rate and trade policy reform which aimed at kick-starting non-oil sectors of the economy, policies for the stabilization of balance of payments and prices, efforts to downsize the public sector and improvements of the management of publicly owned assets. Additionally, the country "eliminated import licenses and agricultural marketing boards, lifted price controls, launched a program of privatization, and took steps toward the deregulation of the banking system" (ibid).

From the perspective of Nigerian observers, the SAP years (1986-1992), delivered negative outcomes for the economy and citizenry:

- "Inflation has assumed a doomsday scenario since the inception of the SAP in July 1986 (from 5.4\% in 1986 to $40.9 \%$ in 1989), and is threatening to destroy the very fabric of Nigerian society. It is the principle price of Babangida's SAP measures, which include external debt management strategies, SFEM/FEM/IFEM, removal of subsidies on petroleum products and fertiliser, privatisation and commercialisation, trade liberalisation, and interest rate deregulation" (Anyanwu, 1992, p. 5).

- "In fact, SAP came at a time when Nigeria was beset by a charged political atmosphere fueled by the biting economic hardship that hit most families. Cognizant of the situation, the Government in power still went ahead to implement the IMF conditionality that led to many unpleasant consequences such as workers losing their jobs through retrenchment, many people not being able to afford most of the necessities of life due to wage cuts and withdrawal of subsidies, skyrocketing inflationary situation occasioned by currency devaluation, high rates of unemployment, etc." (Nwagbara, 2011, p. 31).

- "The civil service remains the hope of the vast majority of Nigerians and it has direct impact on the success or failure of any administration. But in just eight years, the Structural Adjustment Programme instituted by the Babangida administration destroyed the values, dignity of civil service which have painstakingly been built since 1934"- Mr. Liyel Imoke, former Governor of Cross River State, Nigeria (Daily Post, 2013).

The World Bank explained these outcomes on the basis that the SAP was not followed as prescribed: "from 1987 to 1990, Government's stop and-go fiscal policies undermined the SAP's stabilization objectives. Subsequently, runaway extra budgetary expenditures caused skyrocketing inflation. Yet, despite these reversals, overall growth performance under the SAP was good" (World Bank, 1994, p. 3). In the area of public debt management, the SAP "included a plan for selective external borrowing-with some increase in indebtedness at a lower rate than that projected for export growth. Nigeria's creditworthiness was to be restored over time. But actuality did not exactly follow this plan" (World Bank, 1994, p. 3). Anyanwu (1992) gives the four debt management strategies under SAP as refinancing, rescheduling, the provision of new loan facilities and debt-equity swaps: 
1. Refinancing, or the transformation of short-term debt obligations into long-term obligations, which are subsequently super-imposed on existing long-term debt.

2. Rescheduling, in which the terms of relevant maturities change: the result is a different duration for debt service, while outstanding liabilities remain.

3. New loan facility, or the procurement of new external loans for trade support, export development or as a standby facility

4. Debt-equity swap, by which institutions, corporate bodies and persons to whom Nigeria was indebted (externally) exchange the debt for equity or shares in Nigerian enterprises.

The SAPs did not ameliorate Nigeria's debt burden. The Central Bank of Nigeria stated that in 1986, 1989 and 1991, the Government rescheduled payments of US\$7.0 billion, US\$6.0 billion and US\$3.0 billion debts respectively to the Paris Club of Creditors (Okoro, 2013). Also, the Government continued to acquire debt: in 1987, Decree No 30 of 1978 was repealed in order to allow the Government to raise another jumbo loan (Ijeoma, 2013). Politically, the Nigerian situation remained unstable; General Abacha overthrew the regime of General Babangida in 1993. While the Abacha regime (19931998) did not acquire new debt, the country ceased repayments due to the Paris Club. As a result, "arrears accumulated, while new disbursements came from the multilateral creditors" (Okoro, 2013, p. 9). In 1998, following the death of General Abacha, the regime of General Abubakar (1998-1999) conducted elections, and handed over to the civilian administration of President Obasanjo. This administration (1999-2007) prioritised the repair of Nigeria's image globally, as well as the improvement of the country's economic situation, of which the debt burden was a critical and crippling element.

By the early 2000s, Nigeria's debt obligations had skyrocketed to the extent that the Government embarked on an aggressive debt relief campaign. In 2005, the then Nigerian Minister of Finance, Dr. Okonjo-Iweala, who led the campaign for debt relief, presented the country's debt profile;

“Nigeria 's external debt stands presently at US\$34 billion. About \$28 billion or $85 \%$ of the debt is owed to the Paris Club of 15 creditor nations. Only $8 \%$ of the debt is owed to multilateral institutions such as the African Development Bank and the World Bank whilst the balance of $7 \%$ is owed to the London Club of commercial creditors and holders of Promissory Notes. Nigeria does not owe the IMF any money. The first fact therefore is that Nigeria's debt problem is really "a Paris Club debt problem" (Okonjo-Iweala, 2005, p. 5).

The figure below shows the composition of debt owed by Nigeria to external creditors in 2005: 


\section{Nigeria's External Debt and Creditors}
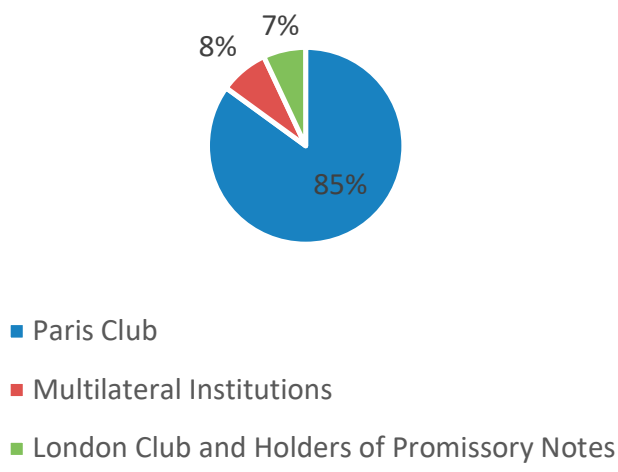

Figure 2: Nigeria's External Debt and Percentages Owed to Creditors in 2005

Okonjo- Iweala went on to argue that "If Nigeria were to fully service its external debt every year, annual debt service would amount to approximately US\$3 billion - \$2.3 billion to the Paris club, and $\$ 0.7$ billion to the multilateral and commercial creditors. The ownership structure of the debt is such that the Federal Government pays $75 \%$ of the debt service whilst $25 \%$ approximately is serviced by the states. Therefore, fully servicing the $\$ 3$ billion every year would mean that the Federal Government would have very little left for the capital budget over the next 5 to 7 years as the Federal Government 's portion of such debt service would virtually eat up all of the capital budget, especially when it is considered that we also have domestic debt service amounting to about \$1.4 billion a year". (Okonjo-Iweala, 2005, p. 1).

The increase in Nigeria's debt obligations between 1985 and 2005 is presented in the table below:

Table 5: Increase in Nigeria's Debt Obligations 1985-2005

\begin{tabular}{llll}
\hline Element & 1985 & 2005 & Percentage Increase \\
\hline External Debt Obligations & US\$19billion & US\$34billion & $79 \%$ \\
Annual External Debt Service & US\$1.5billion & US\$3billion & $100 \%$ \\
\hline
\end{tabular}

In summary, SAPs did not prevent the worsening of Nigeria's debt, as during the SAP era (1986 -1992), the Government rescheduled its payments to the Paris Club of Creditors, resulting in increased liabilities, even as it acquired more debt. While it was the recklessness of successive governments which created the debt burden, SAPs did little to impose fiscal discipline, reduce government corruption, or substantially improve government policy in the area of debt management. 


\subsubsection{Structural Adjustment Programs in Rwanda}

In the 1970s and 1980s, Rwanda's main sources of revenue were exported cash crops, particularly coffee, tea and tin. The Central Government was led by President Habyarimana, who had come to power through a coup in 1973. While the length of this administration (1973-1994) provided stability in the political arena, it did little to douse the economic and social tensions which existed from the colonial era.

During the 'Scramble for Africa' (1884), Rwanda was partitioned into German East Africa. After the First World War (1914-1919), the League of Nations granted Belgium an administrative mandate over the territory, which evolved into a trustee-ship granted by the United Nations in 1946, after the Second World War (Baker, 1970). During the colonial era, the Tutsi ethnic group favoured by the Belgian Government gained political and economic influence over the Hutu ethnic group. It has been argued that the emphasis of race and ethnicity by the Belgian Colonial Government, particularly as these factors affected political and economic opportunities, polarised perceptions and relations between Tutsi and Hutus (Hintjens, 1999; Kumar \& Tardif-Douglin, 1996). Between 1959 and 1961, a Hutu-led revolution reconfigured the political, economic and social systems of Rwanda. As a result, United Nations states that "by 1962, when Rwanda gained independence, 120,000 people, primarily Tutsis, had taken refuge in neighbouring states to escape the violence which had accompanied the gradual coming into power of the Hutu community" (United Nations, n.d.). The exile of the Tutsis did not necessarily reduce the tensions which sparked the conflict: "the Hutu, enforcing a one-party regime in which the Tutsi had no voice, lived from then on with the spectre of counterrevolution. The hostilities between the two groups were exacerbated by the Cold War, as the Communist countries helped arm the counter-attacks of the Tutsi refugees, while the Western countries provided support to the Hutu regime" (Gasana, 2002, p. 26).

Rwanda's debt profile expanded during the late 1980s and early 1990s with loans obtained by the Habyarimana Government from the World Bank, the IMF and Bilateral Creditors. While Rwanda had not suffered during the first oil crisis in the mid-1970s, the second crisis of 1979 caused a rise in interest rates, and the country struggled to both pay off old loans and get new ones approved (Chirwa, 2015). As its debt profile rose, the economic situation of Rwanda was further compounded by a severe shock in the late 1980s, i.e., the drop in global prices for Rwanda's main export crops, i.e., coffee, tin and tea which resulted in reduced revenues for the country. Chossudovsky (1995) explains the situation: "in 1987, the system of quotas established under the International Coffee Agreement (ICA) started to fall apart. World prices plummeted, the Fonds d'egalisation (the State coffee stabilisation fund) which purchased coffee from Rwandan farmers at a fixed price started to accumulate a sizeable debt". After the 1989 meeting of the International Coffee Association, the global price of coffee fell by more than 50 per cent (ibid). 
In a bid to mitigate the shortfall in its revenue, the Government implemented an IMF SAP in November 1990 (Toussaint, 2004). This SAP incorporated wide-ranging policy reforms including a reduction in the role of the state in the economy through privatisation and the removal of state-guaranteed prices for coffee producers, and the removal of coffee subsidies. Also implemented were policies on import liberalisation and a freeze on public sector wages. A social safety net, through a Social Action Plan was integrated into the SAP in a bid to mitigate the adverse effects of economic restructuring on the poor. However, this Plan did not prevent the resultant economic and social problems which emanated directly from the SAP (Joint Evaluation of Emergency Assistance to Rwanda, 1996). According to Chossudovsky (1995), these economic and social problems included the following:

- A 50 per cent devaluation of the Rwandan Franc, which caused a spike in the prices of consumer goods, and a reduction in real earnings. This devaluation occurred a month after the entry of the SAP, in November 1990.

- External debt, which had doubled between 1985 and 1989, increased by 34 per cent between 1989 and 1992.

- Weakening of the state and the collapse of public services such as health and education. The introduction of fees for primary school pupils led to a reduction in enrolment rates.

- IMF control of public finances: the Government was unable to transfer finance to the Fonds d'egalisation (State Coffee Stabilisation Fund).

- A second devaluation, in the middle of the civil war, caused further increases in the price of fuel and consumer goods.

- Coffee production reduced by another 25 per cent, alongside a second currency devaluation ordered by the IMF in 1992.

Crucially, economic pressures brought about by the terms of the SAP exacerbated underlying social tensions within, and between ethnic groups. In 1990, Tutsi refugees grouped under the umbrella called the Rwanda Political Front (RPF) had begun to launch military attacks into Rwanda, which escalated into a three-year civil war. Funds obtained from World Bank and IMF loans were diverted towards the procurement of weapons by the Hutu-dominated Government. Chossudovsky \& Galand (2004) state that despite the SAP, the Government obtained IMF approval to grow the size of the army: "following the "green light" given by the IMF in November 1990, the army suddenly swelled from 5,000 to 40,000 men, thus supposing external financing despite budgetary austerity. Juvenile delinquents, resulting from an impoverished society were enrolled by the thousands into civilian militia, responsible for the genocidal killings and massacres".

In the midst of the economic crisis, a civil war, and peace negotiations between the RPF and the Government of Rwanda, IFIs insisted on political reforms, specifically a multi-party democratic system of governance (Andersen, 2000). In spite of these re- 
forms, Hintjens (1999) suggests during the period of economic crisis and reforms, a section of the Hutu elite began to prepare plans for a genocide of Tutsis. In 1990, Kagura Magazine published The 'Ten Commandments of the Hutu', which stated "The Batutsi are bloodthirsty and power-hungry and want to impose their hegemony on the people of Rwanda using armed force" (Rwandafile, n.d.)". The Commandments allude to strategies employed by the Tutsi to dominate the country, and outline measures through which Hutus could contain, and eventually thwart Tutsi domination (ibid). In 1993, the Arusha Peace Accords, brokered by the OAU, France and the United States of America, were signed between the Government of Rwanda and the RPF. These Accords established a transitional Government which included representatives of the RPF and five political parties, even as it spoke to changes in the political, economic and military structures of Rwanda. On 6 April 1994, the Rwandan genocide, in which more than 800,000 people died, was triggered when the plane carrying President Habyarimana of Rwanda was shot down near Kigali airport. Following the plane crash and death of President Habyarimana, the BBC reports that "within hours a campaign of violence spread from the capital throughout the country, and did not subside until three months later" (British Broadcasting Corporation, 2011).

While it was underlying ethnic and social problems which fostered violence, and ultimately the genocide, it can be argued that insensitivity to and minimal consideration of these problems by the IMF and the World Bank in the prescription and implementation of the SAPs, contributed to the economic conditions which enabled the escalation of conflict. Specifically, the loans Rwanda obtained prior to the SAPs have been described as irresponsibly conceived and disbursed. Chossudovsky \& Galand (2004) state that "the debts of the former Government (1990-1994) were mainly used to finance the armed forces and civilian militia". This position is corroborated by Toussaint (2004) who argues that;

"At the beginning of the 1980s, when the Third World debt crisis broke out, Rwanda (like its neighbour Burundi) had an extremely low level of indebtedness. Elsewhere, the World Bank and the IMF jettisoned their policy of active lending, preaching austerity instead. In Rwanda, however, they adopted a different approach, and began to lend large sums. Rwanda's foreign debt increased twenty fold between 1976 and 1994. In 1976, it stood at 49 million dollars; by 1994, it was more than a billion dollars. Most of this growth took place after 1982. The country's main lenders were the World Bank, the IMF and related institutions". The table below shows the increase in Rwanda's debt obligations between 1976 and 1994. 
Table 6 Rise in Rwanda's external debt obligations between 1976 and 1994

\begin{tabular}{lll}
\hline 1976 & 1994 & Percentage Increase \\
\hline US\$49,000,000 & US\$1,000,000,000 & $1941 \%$ \\
\hline
\end{tabular}

In July 1994, the RPF in coalition with four political parties formed a Government of National Unity. The new Government also assumed the responsibility of debt obligations of up to US\$1billion. Toussaint (2004) notes that the World Bank and IMF refused to cancel debts incurred by the Habyarimana regime, but promised debt relief for the future. Instead, the Government undertook SAP II (1998-2001), comprising macroeconomic policy and structural reforms which were developed and implemented in "close consultation with" the World Bank and IMF (International Monetary Fund, n.d.).

In summary, the purpose and design of the SAPs were flawed in the sense that in insisting on political reform, the IMF did not account for evident and relevant socioeconomic factors, such as the displacements to power structures of the elite and resultant reactions, as well as the open conflict between the Rwanda Patriotic Front and Government of Rwanda. Furthermore, the IMF was able to direct the flow of SAP funds; for example, it was able to prevent the transfer of state funds to the Coffee Stabilisation Fund, but it either did not observe or effectively prevent the diversion of funds towards the purchase of armaments.

\subsection{The Failures of Structural Adjustment Programs}

Nigeria and Rwanda undertook SAPs to address economic contractions, which were exacerbated by debt problems. These Programs were intended to rectify perceived faults in macroeconomic, regulatory, and administrative systems which were considered impediments to positive economic performance and effective economic management. However, it was the case that the SAPs, in both countries, weakened economies, and resulted in deleterious effects on large sections of the population. Crucially, SAPS did not prevent, and may have aided the rapid increase of the debt profiles of Nigeria and Rwanda.

SAPs have been criticised for many reasons, including the 'standard-form' approach: in Nigeria and Rwanda, these Programs eroded the policy-making and economic management capacities of governments, in favour of market-driven mechanisms. The Washington Consensus (the World Bank and the IMF), which developed SAPs sought to prescribe a set of policies without due consideration for the subjective contexts of implementation. Stiglitz (2008) explains this approach: "whatever, its original content and intent, the term "Washington Consensus", in the minds of most people around the world, has come to refer to development strategies focusing around privatization, liberalization, and macro-stability (meaning mostly price stability); a set of policies predicated upon a strong faith - stronger than warranted --in unfettered markets and aimed at 
reducing, or even minimizing, the role of government" (Stiglitz, 2008, p. 41). In both Nigeria and Rwanda, market mechanisms were not developed to the extent that they could replace government or state-backed administrative systems. Additionally, in dealing with borrower countries, the reluctance of IFIs to adequately consider the political and social consequences of economic changes has been evidenced as problematic.

Furthermore, reforms led by the World Bank and IMF are often interpreted as impositions which infringe upon state sovereignty (Soludo \& Ogbu, 2004). The World Bank and IMF often attached conditionalities to the provision of finance, such as reforms discussed in Sections 2.2.1 (Nigeria) and 2.2.2 (Rwanda). The IMF defines conditionalities as "both the design of IMF-supported programs - that is, the macroeconomic and structural policies-and the specific tools used to monitor progress toward the goals outlined by the country in cooperation with the IMF" (International Monetary Fund, 2016). Reforms and conditions reconfigure the structures of national economies and societies, and erode upon the power and authority of the state. Importantly, the extent to which IMF credit-worthiness improves social capital with other financial institutions is highlighted by the 2006 report of the European Network on Debt and Development which states: "the IMF's 'gatekeeper' role makes the conditions the Fund attaches to its program hugely potent. If a poor country does not fulfil the conditions that the IMF attaches to its lending, then not only does it forfeit IMF development finance, it will also potentially forfeit all other sources of much-needed donor finance" (European Network on Debt and Development, 2006, p. 5). However, the IMF has justified conditionalities on the assertion that borrower countries are made to adjust their policies to tackle the problems which created the need for financial assistance in the first place (International Monetary Fund, 2016). Similarly, the World Bank has justified conditions on the premise that these are necessary for development effectiveness, and forestall the misuse of resources (World Bank, 2005). The governance structures of the World Bank and the IMF give greater voting and decision making powers to the largest shareholders, which are the Group of Seven (G7) of industrialised countries. It follows that reforms are often viewed with suspicion, and met with resistance in borrower countries. To illustrate, in Nigeria, the military dictatorship of General Babangida thought it necessary to put terms attached to an IMF Ioan facility to a public debate. While the World Bank and IMF are empowered by their respective articles of agreement to determine the terms upon which finance is provided to borrower countries, it can be argued that conditionalities reflect the inequalities of bargaining power between a borrower country and institutional creditors. In 2005, the World Bank acknowledged that conditions have been "perceived as overly excessive or intrusive", and highlighted the need for reforms to emanate from the domestic agenda of countries (World Bank, 2005, p. 1). Following reviews of policy effectiveness, and in response to growing criticisms, conditionality policies were amended towards country-led design of reform programmes. The debt-related policy changes of the World Bank and IMF are discussed extensively in Chapter 3 of this thesis. 
By the mid-1990s, the economic situation of borrower countries provoked a global campaign for debt relief. The implication of rising debt profiles was that developing countries spent the greater share of their resources on servicing debt, rather than national development. Towards the end of the 1990s, the debt burden on developing countries came to be seen as largely the invention and responsibility of creditors, whether international institutions or industrialised countries. The campaign for debt relief was implemented by a coalition of academics, activists, borrower countries, and celebrities. This movement put forward the intellectual, moral, economic and policy arguments for the outright removal or significant reduction of debt burden of borrower countries. These arguments are examined in the next section.

\subsection{The Debt Relief Movement}

From the mid-1990s, a concerted and loud campaign which sought debt relief for developing countries fused into a movement. Jubilee 2000 debt campaign, as the global movement was known, ultimately led to the cancellation of US\$100billion worth of debts owed by poor countries (Advocacy International, 2000). This movement, which drew on Old Testament principles to argue for debt forgiveness to coincide with the new millennium (Denny \& Elliot, 1999), organised a successful public information campaign opposing the costs of debt to developing countries. The campaign integrated arguments and reasoning put forward in favour of debt forgiveness or debt relief by academics, policy makers, borrower countries, charitable organisations, and other interest groups. These arguments for debt relief can be organised into three main sections, i.e., the notion of odious debt, the joint responsibility of borrowers and creditors in building debt profiles and liability of developing countries, and the idea that the imperative of development supersedes the repayment of debt obligations.

\subsubsection{Odious Debt}

By the late 1980s, the amounts required by borrower countries globally, for the purpose of debt servicing had assumed immense proportions. As borrower countries struggled to achieve economic growth, they repeatedly rescheduled payments to creditors. These reschedulings postponed the period of debt maturity, and increased the liabilities of borrower countries through increased interest rate payments. The outcome on national economies was that, in national budgets, debt servicing was often allocated a greater proportion of resources than development-related activities or social services provided by the state. During this period, the notion of odious, or repulsive debt emerged.

Odious debt is premised on the principle of international law that debt can be repudiated if it is not obtained or utilised in the best interests of the state. Odious debt is rooted in the same legal principle which protects individuals when credit is obtained in their name, but without their consent. In the same way, international law holds that 
sovereign debt incurred without the consent of the people as odious, and there is a persuasive argument that such debt should not be transferred to successor governments, especially if creditors are aware of the circumstances of debt acquisition (Kremer \& Seema, 2002). According to the United Nations Conference and Trade and Development, the concept of odious debt seeks to provide moral and legal support to sever in whole or in part, debt obligations incurred by a previous government (Howse, 2007).

From the mid-1980s, borrower countries began to seek debt relief, as their debt burdens had expanded to the extent that countries were compelled to choose between development-related spending, or satisfying obligations owed to creditors. In 1987, at a conference of the OAU, Thomas Sankara, then President of Burkina Faso stated "debt cannot be repaid, first because if we don't repay, lenders will not die. That is for sure. But if we repay, we are going to die" (Sankara, 1987). Academics and development professionals also provided intellectual arguments in favour of debt forgiveness. Writing in 1990, Paul Krugman emphasized the necessity of debt relief for borrower countries on the premise that 'debt relief is cheap'. Krugman estimated that the total value of debt owed by borrower countries amounted to less than one-third of 1 per cent of the national incomes of creditor countries (Krugman, 1990). In 1994, Kevin Watkins argued that debt reduction and cancellation was necessary to reverse developmental decline and kickstart recovery of the African continent. Watkins noted that a significant proportion of aid finance was directed towards satisfying debt obligations (Watkins, 1994). He went further to propose reforms for creditor management of debt stock including; the recommendation that the Paris Club write-off between 70 per cent and 100 per cent of debt stock owed to governments, the increase of the amounts of debt eligible for reduction and rescheduling, the establishment of debt repayment ceilings compatible with social and economic recovery, and support for more debt-for-development swaps, especially on national programmes connected to welfare improvement. In the case of the IMF, Watkins recommended that the institution acknowledge its mismanagement of the debt situation of African countries, and commit its own resources towards paying off debt obligations through the sale of gold stocks or a new issue of special drawing rights (ibid).

In Nigeria and Rwanda, debt burdens increased even after the contracting government or administration had exited office. The extent to which debt burden constricted the economies and populations of borrower countries is displayed in the cases of Nigeria and Rwanda discussed in the sections below.

\subsubsection{Nigeria's Debt Burden}

In the case of Nigeria, successive governments attempted to repudiate debt incurred by previous administrations and regimes. Under the Abacha regime, Nigeria requested debt relief from the Paris Club, and ceased its loan repayments when its request was 
not granted. A decade later, the administration of President Obasanjo obtained debt relief from the Paris Club. President Obasanjo explained the necessity of debt relief thus: "Fellow Nigerians, how did we get to the point where our debt burden became a challenge to peace, stability, growth and development? Without belabouring the point, we can identify political rascality, bad governance, abuse of office and power, criminal corruption, mismanagement and waste, misplaced priorities, fiscal indiscipline, weak control, monitoring and evaluation mechanisms, and a community that was openly tolerant of corruption and other underhand and extra-legal methods of primitive accumulation" (Teniola, 2013).

The larger share of Nigeria's debt was incurred during the 1970s and 1980s under the Obasanjo regime, Shagari administration and Buhari regime. Nevertheless, debt obligations ballooned due to high interest rates, and poor economic performance, which led to debt reschedulings. In 2000, President Obasanjo stated "all that we had borrowed up to 1985 or 1986 was around US\$5 billion and we have paid about \$16 billion yet we are still being told that we owe about US\$28 billion. That US\$28 billion came about because of the injustice in the foreign creditors' interest rates. If you ask me what is the worst thing in the world, I will say it is compound interest" (Shah, 2005). Rieffel (2005) supports the assertion that compound interest escalated Nigeria's debt profile, by stating that the ballooning of Nigeria's debt is attributable 'exclusively and directly' to the refusal of commercial creditors (Paris Club) to restructure its claims on Nigeria. Rieffel goes further to note that between 1985 and 2005, Nigeria serviced its debt obligations to international finance institution-creditors without economic restructuring. Simultaneously, the country met its obligations to other bilateral creditors in return for debt relief, even as it successfully negotiated the exchange of bank debt for bonds at a discount of 60 per cent with non-Paris Club commercial creditors (Rieffel, 2005).

Nonetheless, the country's debt obligations continued to increase. By December 2004, Nigeria's total debt obligations stood at of US\$35.994 billion, or 4.82 trillion Naira, converted at the rate of N134 Naira to $\$ 1$. This amount spread across the population of 130 million people, yielded a debt of 37 million Naira per person. At the same time, the GDP Per Capita or average annual income of Nigerians was estimated at N3,379.50. In 2005, the Debt Management Office estimated that it would take 22 years to pay off the debt to the Paris Club, if each Nigerian saved half $(\mathrm{N} 1,689.75)$ of their total annual income. (Debt Management Office, 2005).

\subsubsection{Rwanda's Debt Burden}

The greater proportion of Rwanda's debt was acquired after the fall in coffee prices on the international market. Faced with economic pressures and civil strife in the 1980s, the Habyarimana regime obtained credit facilities from the IMF and the World Bank, as well as Bilateral Creditors. By 1994, after a three-year civil war, a genocide, and with a 
new government, the country's debt had climbed to over US\$1billion. 84 per cent of this amount was owed to multilateral creditors- the World Bank (55 per cent), the African Development Bank (25 per cent) and other institutions (4 per cent). The remainder 16 per cent of Rwanda's external debt was owed to Bilateral Creditors, of which France held 8 per cent (UK Parliament Select Committee on International Development, 1998). The country's external debt was equivalent to 85 per cent of its GDP (Kayigamba, 1997), and the net present value of the debt to exports ratio was calculated at 550 per cent, expected to rise to 732 per cent by 2000 (UK Parliament Select Committee on International Development, 1998). The composition of debt owed to external creditors is shown through the figure below:

\section{4: Rwanda Creditors in 1994}

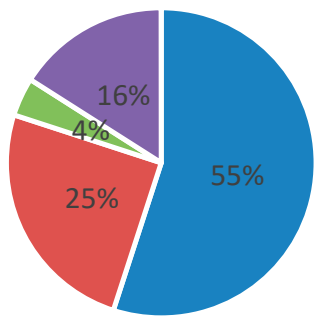

- World Bank

- African Development Bank

- Other Institutions

- Bilateral Creditors

Figure 3: Rwanda's External Creditors in 1994

For Rwanda, the argument that a country was liable for its sovereign debt, however acquired or utilised, proved more compelling than the notion of odious debt. It was often the case that borrower countries accepted liability for sovereign debt in a bid to maintain creditworthiness; the 1998 report of the UK Parliament Select Committee on International Development notes the example of Kenya which declined to apply for debt relief in order to demonstrate its ability to "stand on its own two feet" (UK Parliament Select Committee on International Development, 1998). In 1997, the then Minister of Finance and Economic Planning of Rwanda, Donald Kaberuka stated that the country accepted responsibility for debt acquired by the Habyarimana regime. He went further to state that while Rwanda was committed to servicing sovereign debts acquired under the Habyarimana regime, the country had applied to be considered under the Heavily Indebted Poor Countries (HIPC) Initiative of the IMF and World Bank (Kayigamba, 1997). As a result, the country agreed to undertake a second SAP to qualify for debt relief in 2005. 


\subsubsection{Joint Responsibility of Borrowers and Creditors}

In the 1970s, creditors often provided loans without proper due diligence. The prevailing economic conditions of the time, i.e., high levels of savings by oil exporter countries and high commodity prices made it possible for creditor institutions to provide large credit facilities to borrower countries without corresponding levels of scrutiny. Borrower countries were not required to provide justification as to the necessity or use of credit. Importantly, credit was often provided at variable interest rates, which rendered indeterminate the total amounts payable by borrower countries. The IMF has noted that much of the credit provided during the 1970s took the form of 'national interest' lending, by which Creditor Governments sought to stimulate exports, generate domestic employment and foster friendly relations with borrower countries. The implicit risk that debts would not be repaid was accepted by creditor countries (International Monetary Fund, 1999). This position is corroborated by a 1992 report of the Forum on Debt and Development (FONDAD) which highlights 'thoughtless' and 'irresponsible' overlending by private and official creditors during the commodity boom of the 1970s, as a factor which exacerbated the debt obligations of borrower developing countries. Additionally, the report points to other factors including, 'poor' and 'impractical' advice provided by IFIs, punitive terms attached to debt reschedulings and the egregious arrears which followed, as well as protectionist policies of industrialized countries (Forum on Debt and Development, 1992). By the late 1980s, the combination of institutional policy, economic shocks and SAPs served to create a difficult debt situation for borrower countries.

IFIs recognised that debt repayments often created onerous burdens on borrower countries, and therefore developed mechanisms by which borrower countries could obtain debt relief. Successive mechanisms, including the Venice Terms, Toronto Terms, London Terms, Naples Terms and Lyons Terms offered a combination of moratorium and grace periods, debt cancellation, and debt consolidation to borrower countries. Debt relief was predicated on three conditions, the first of which was documentary demonstration of its macroeconomic situation, balance of payments and debt burden. Secondly, the country would present a request for debt relief, stating its debt stock and scheduled debt service. Thirdly, the country would be required to implement a SAP supported by the IMF (Villanova \& Martin, 2001). The IMF provided the intellectual underpinning for the conditions associated with debt relief mechanisms of the Paris Club, by stating that debt relief amounted to a temporary measure in the absence of rectification of the underlying conditions which created a debt burden. Also, the IMF argued that outright debt cancellation or forgiveness would be unfair to poor countries which maintained good policies and had manageable debt. Furthermore, the IMF stressed the reality of the financial cost of debt cancellation to itself and creditor countries, as well as the necessity of ensuring continued flows of financing to borrower 
countries (International Monetary Fund, 2000). The debt relief mechanisms of the Paris Club, as aggregated by Villanova \& Martin (2001) are outlined in the table below:

Figure 4: Debt Relief Mechanisms of the Paris Club

\begin{tabular}{|c|c|c|}
\hline Debt Relief Mechanism & Year & Relief Measures \\
\hline $\begin{array}{l}\text { 1. Venice Terms for Poorest } \\
\text { Sub-Saharan African } \\
\text { Countries } \\
\text { (Lewis, 1987) }\end{array}$ & 1987 & $\begin{array}{l}\text { - US\$500million annually in extra direct aid from Western } \\
\text { countries } \\
\text { - Debt relief measures } \\
\text { - US\$500million in new IMF Loans }\end{array}$ \\
\hline 2. Toronto Terms & 1988 & $\begin{array}{l}\text { - Official Development Assistance Debt: rescheduled to } 25 y e a r \\
\text { maturity period, with 14year grace period. Moratorium } \\
\text { interest rate as low as original interest rate. } \\
\text { - Non-Official Development Assistance Debt } \\
\text { a) Partial Write-Off: Cancellation of } 33.3 \% \text { of consolidated debt. } \\
\text { Outstanding debt rescheduled for } 14 \text { year period on the basis } \\
\text { of market interest rates. 8year grace period. } \\
\text { b) Concessional Interest Rates: consolidated debt rescheduled } \\
\text { for } 14 \text { year period using below market interest rates (less than } \\
1 / 2 \text { or } 3.5 \% \text { of market value-depending on which calculation } \\
\text { gave the lower rate). 8year grace period. } \\
\text { c) Longer Repayment Period: Consolidated debt rescheduled for } \\
25 y e a r \text { period at market rates of interest. } 14 y e a r \text { grace } \\
\text { period. }\end{array}$ \\
\hline 3. London Terms & 1991 & $\begin{array}{l}\text { - Official Development Assistance Debt: rescheduled to 30year } \\
\text { maturity period, with } 12 \text { year grace period. Moratorium } \\
\text { interest rate as low as original interest rate. } \\
\text { - Non-Official Development Assistance Debt } \\
\text { a) Partial Write-Off: Cancellation of } 50 \% \text { of consolidated debt. } \\
\text { Outstanding debt rescheduled for } 23 y e a r \text { period on the basis } \\
\text { of market interest rates. 6year grace period. } \\
\text { b) Interest Rate Reduction: } 100 \% \text { of consolidated debt } \\
\text { rescheduled for } 23 y e a r \text { period. Interest rates low enough to } \\
\text { reduce present value of debt service by } 50 \% \text {. No grace } \\
\text { period. } \\
\text { c) Combination of Reduction of Interest Rate with Partial } \\
\text { Interest Payment Capitalization: Consolidated debt } \\
\text { rescheduled for } 23 y e a r \text { period at market rates of interest. } \\
\text { Interest not charged on capitalized interest. } 5 y e a r \text { grace } \\
\text { period. }\end{array}$ \\
\hline
\end{tabular}

Additional mechanisms, i.e., the Naples and Lyons terms provided further debt relief to Heavily Indebted Poor Countries who had benefited from debt relief under the Toronto or London Terms (Villanova \& Martin, 2001).

However, the notion of joint responsibility did not positively impact upon the appeals of Nigeria and Rwanda for debt relief. The larger part, i.e., 85 per cent of the external debt of Nigeria was owed to the Paris Club. The primary factors which enabled the rapid and unsustainable escalation of Nigeria's debt were the original terms of credit, particularly variable and high interest rates, which did not anticipate the economic conditions which altered the country's income, and therefore its ability to service its obligations to creditors. Thereafter, the liabilities of the country increased through 
repeated reschedulings which served to simultaneously postpone and increase its debt obligations. Subsequently, during the regime of General Abacha, the country unsuccessfully sought debt relief, and ceased payments to the Paris Club, which further escalated its external debt profile. Crucially, the country's high levels of indebtedness caused it to have a poor credit rating. Moss et al, (2004) noted that in 2003, none of the major international rating agencies gave Nigeria a sovereign commercial credit rating. Simultaneously, IMF and World Bank assessment of Nigeria's creditworthiness rendered it ineligible for IBRD assistance. Nigeria was unable to access the IDA-only list of the World Bank which made countries eligible for concession loans, grants and debt relief programs. As a result, the country was excluded from the HIPC initiative of the IMF, and the soft Paris Club Terms, e.g., Naples terms which would have reduced its debt obligations. Nigeria was the only poor country in the world which was not placed on the IDA-only list (ibid). It followed that the country embarked on several rounds of negotiations, and adopted a custom-designed range of economic, legal and structural reforms with the Paris Club and IFIs towards obtaining debt relief in 2005.

In the case of Rwanda, IFIs, specifically the World Bank and IMF have been held responsible for the country's high level of indebtedness in 1994 (Toussaint, 2004; Chossudovsky \& Galand, 2004). Debt obligations increased rapidly during the SAP implemented by the Habyarimana Government, even as conditionalities imposed by the IMF did not prevent the diversion of finance towards improper uses. Importantly, creditor institutions did not sufficiently consider the effects of economic contractions and institutional changes on the political context. Chossudovsky \& Galand (2004) conducted an investigatory visit to Rwanda at the end of the genocide and civil war, after which they recommended reparation by multilateral and bilateral creditors in the form of unconditional and total cancellation of debt incurred between 1990 and 1994. However, creditor institutions (IFIs) refused to grant debt relief to the Post-Genocide Government, and insisted upon the implementation of SAPs as a prerequisite. In 2005, Rwanda obtained debt relief after it undertook a second SAP in 1998, financed by its Bilateral Creditors, the World Bank, the IMF and the AfDB (African Development Bank Group, 2001).

\subsection{Development, not Debt Burdens}

A central argument of the Jubilee 2000 movement was that debt burdens constituted a constraint on resources of poor countries, and inhibited investments towards development. Greenhill (2002) gives the central point of the Jubilee 2000 campaign as thus: money rights should not be superior to human rights. In other words, poor countries should not be hindered from the pursuit of development by the claims made upon their resources by rich country creditors. The Jubilee 2000 debt campaign estimated that for every US\$1 low-income countries received in aid, they paid back up to US\$2.30 in debt service (Jubilee Debt Campaign, n.d.). 
Jubilee 2000 movement benefited from a change in the ideology of IFIs. The 1990s witnessed the reintroduction of governance into the development agenda through the rise of the NIE school of thought, which attributed the failures of the 1980s reforms to the absence of requisite institutions within developing countries (See 1.3). This position, i.e., that there is a direct correlation between the quality of governance and developmental outcomes was adopted by IFIs. As a result, governments were again, as in the 1970s, considered the primary drivers of economic and social progress, and the institutions responsible for the formulation and implementation of development outcomes. There were several manifestations of this ideology, including indexes to measure the quality of governance (CPIA, Doing Business), and technical assistance interventions which sought to reform governance systems, and improve the capacities of public service institutions. Furthermore, the notion that governments should deliver developmental outcomes was expressed through several mechanisms, the most notable of which is the Millennium Development Goals (MDGs), adopted by the governments of 189 countries at the United Nations General Assembly in September 2000. The MDGs outlined a comprehensive global development agenda, organised into 8 actionable and targets to cover poverty, hunger, basic education, gender equality, health, environment and technology (United Nations Millennium Project, 2006). These goals were intended to guide each country in the formulation and implementation of development policy, as well as the utilisation of resources.

The World Bank and IMF accepted the achievement of development goals as justification for debt relief. To illustrate, the IMF now posits that debt relief unlocks resources which are directed towards social services, such as health and education, even as countries are better equipped to manage public debt (International Monetary Fund, 2016). As the Governments of Nigeria and Rwanda sought debt relief, they adopted the development-related arguments put forward by the Jubilee 2000 debt campaign, and embraced the MDG agenda. In 2005, a committee of the Nigerian Senate (upper legislative house), presented some of the country's development-related arguments for debt relief, particularly that the country's debt stock severely limited programs in support of economic and human development, and threatened the country's ability to meet the MDGs by 2015. Also, the committee argued that Nigeria was a poor country, and its oil revenues which equated to 50cents per day for each citizen. As such, the annual debt service obligation of US\$3billion, which was 13 times and 5 times its spending on health and education respectively, only served to perpetuate a vicious cycle of austerity and poverty (Senate of the Federal Republic of Nigeria, 2005). In the case of Rwanda, the Post-Genocide Government accepted responsibility for sovereign debt incurred by the previous regime in exchange for international recognition (Chossudovsky, 1995). Thereafter, IFIs structured aid finance towards repayment through several mechanisms, including a Multilateral Trust Fund of US\$55.2million, which was accessible by the Government of Rwanda, (but directed towards service of debts owed to the World Bank), the AfDB and the International Fund for Agricultural Development (IFAD). The outcomes 
of continued debt service included a drastic fall in wages for civil servants, the sale of state-owned assets, and the collapse of per capita income from US\$360 before the war to US\$140 in 1995 (ibid).

Nigeria and Rwanda leveraged on the Jubilee 2000 debt campaign, and the refocus within IFIs on government delivery of economic and social improvement. Both countries integrated the achievement of the development objectives, particularly the MDGs into requests for debt relief. It followed that debt relief obtained by both countries in 2005 was contingent on the achievement of clearly specified and measurable developmental goals.

\subsection{Analysing the Relationship between Law and Economic Development through the Debt Burden Experiences of Nigeria and Rwanda}

This chapter has presented the evolution of the economic, policy, and institutional arrangements of Nigeria and Rwanda which led to the acquisition and escalation of debt obligations in the 1970s and 1980s. Also, the chapter discussed the arguments which were put forward for debt relief by borrower countries, and the coalition which campaigned for debt relief in the 1990s and early 2000s. An examination of the political and institutional arrangements of Nigeria and Rwanda in the 1980s and 1990s gives credence to the school of thought which holds that there is a direct correlation between the quality of governance and development outcomes. The arguments of institutional economists, i.e., North, Acemoglu, Robinson, De Soto and others are validated (See Sections 1.2, 1.2.3, 1.2.4, and 1.3).

The Governments of Nigeria and Rwanda prosecuted developmental agendas which were interpreted by, and reflective of the ideological systems which underpinned the models of governance of both countries. During the 1970s and 1980s, Nigeria and Rwanda were governed by military dictatorships (apart from five years of civilian administration in Nigeria between 1979 and 1983). These dictatorships consolidated state power at the highest level of government, from whence they determined and implemented the national development agenda. As explained by Okonjo-Iweala (2012), in the 1970s, many African Governments placed the public sector as the primary driver of activities related to economic development (See 1.2.2). Nigeria and Rwanda typified this approach, in that loans obtained by Governments were often justified on the basis of the pursuit of nationalistic developmentalist visions. Following the debt crisis, IFIs encouraged borrower countries to adopt policies which expressed a particular vision of development, particularly the pursuit of measurable economic development, led by the private sector. Thus, SAPs, supported by lending, sought to reduce the power and influence of the state in some areas of the economy and in social welfare. However, follow- 
ing the failures of SAPS, and the rise of NIE, governance re-entered the international development discourse.

Thus, while it is clear that there is a correlation between governance and development, the preceding study of Nigeria and Rwanda suggests that economic development is dependent on the vision and outcomes desired, as well as the model of governance which drives the implementation of this vision. This study concurs with the assertion of Chang (1999), that the state is the most important actor in development, especially as it is the coordinator for change. The dictatorships which governed both countries in the 1970 s and 1980s pursued nationalistic development agendas, such as the establishment of state-owned enterprises, and to some extent, were successful in implementation. It can be argued that the private sector agenda pursued by SAPs did not effectively take root due to the absence of political will and the weak adoption of this vision by governments. Indeed, IFIs often attributed the failures of SAPs to the abandonment or feeble implementation of reforms by governments (World Bank, 1994). The experiences of the 1970 s to the mid-2000s, i.e., commodity boom, debt crisis, SAPs, debt burden, and debt relief, were largely shaped by policy positions and institutional arrangements. As such, the argument that governance is critical for development is reinforced. However, what becomes evident is the necessity of objectives which are crafted with a robust and clear understanding of the political and social contexts, and directed by a vision that truly is in pursuit of beneficial and tangible results. Governments are imbued with the power and authority to direct and determine economic activity, and thus are able to design political, economic, institutional and social systems towards the realization of the objectives of economic development. Furthermore, several observations can be made on the relationship between legal systems and economic development can be gathered from the experiences of Nigeria and Rwanda:

Firstly, the experiences of both countries clearly emphasise the centrality of law to economic development. At a simplistic level, debt finance was obtained, and debt obligations created by the contractual agreements which were made between creditors, and Nigeria and Rwanda. These agreements were governed by international law, and upheld by international institutions. In a similar vein, the interventions of international institutions, particularly the World Bank and the International Monetary Fund were supported by the Articles of Agreement which establish both institutions. Similarly, in both Nigeria and Rwanda, legal frameworks served as instruments of economic management in military dictatorships and civilian administrations. To illustrate, in Nigeria, to obtain loans from international creditors, the military dictatorships of General Obasanjo and General Babangida both repealed substantive legislation which stipulated the national debt ceiling. In Rwanda, the Government was constrained, to some degree, by the terms of the IMF SAP which controlled the use of government finance.

Secondly, the relationship between law and economic development is shaped by the vision of development, and model of governance operated by countries. Specific political-economic-social contexts determine the nature of interaction between laws, institu- 
tions and economic systems. The perception and deployments of laws and institutions are dependent on the fundamental ideology of the governance system. To illustrate, in Rwanda, the Government was able to provide the military with resources during a SAP which contracted economic resources and negatively impacted upon social conditions. Legal instruments, e.g., policies, legislations or regulations reflect and underpin the vision, agenda, objectives and assumptions of governments. The powers and capacities of institutions which supervise and implement the vision of governments, are to a significant degree determined by the ideals and priorities of the governance system.

Thirdly, the effectiveness of laws is dependent on the existence of strong and independent institutions for enforcement. While it is accepted that a plurality of factors that contributed to the economic problems of the 1970s and 1980s, it is clear that governance systems in Nigeria and Rwanda were instrumental to the rapid economic decline suffered by both countries. To illustrate, IFIs deployed considerable political, intellectual and economic resources towards the enforcement of contractual agreements. It followed that the Governments of Nigeria and Rwanda were held accountable and liable for financial obligations accrued under international law. Conversely, at national level, state and social institutions did not possess the requisite strength or independence to judiciously utilise debt finance, manage the developmental process, or hold governments to account. While the terms of SAPs implemented by the World Bank and IMF attempted to control the use of funds obtained from creditors, the mechanisms of domestic legal systems were not sufficiently robust to adequately govern the disbursement of funds. Thus, the debt problems of Nigeria and Rwanda highlight the critical importance of well-functioning legal systems and supporting institutions for economic management.

Fourthly, while it is necessary to have laws and legal instruments to underpin the institutions which function for economic development, the political economy in which these institutions function is of equal importance. Political, economic, social, and cultural factors must be accounted for in the design or reform of institutions. These factors form the realities and the environment in which institutions will function. As such it is important not to rely upon assumptions, but to properly interrogate the dynamics of environment to identify challenges and opportunities which can determine the functions and operations of institutions.

\subsection{Summary}

This chapter has attempted to outline the objectives of Nigeria and Rwanda in the pursuit of debt relief. Both countries sought relief for the debt burdens which had built from the 1970s, and to rectify the institutional weaknesses which enabled the accumulation of debt. The experiences of Nigeria and Rwanda show that there is an important nexus between legal systems, institutions and economic development. The debt crises 
of the 1980s which followed the commodity boom of the 1970s were triggered by the interplay of policies, policy responses and institutions at international and country levels. In recognition of the role of governance in driving economic development, towards the end of the 1990s and early 2000s, the Governments of Nigeria and Rwanda undertook significant reforms of the legal mechanisms of economic management, through the repeal or enactment of legislation, and the establishment of institutions to manage economic activities. Also, with the emergence of a global development agenda, as expressed through the MDGs, the importance of governance in delivering development has been reinforced.

At international level, IFIs revised the procedures by which they undertook interventions in national economies. From the mid-1990s, the burden of design and implementation of reform programs shifted to borrower countries, as the institutions were more concerned with supervision of reform implementation and the provision of technical assistance. The next chapter examines the reforms undertaken by governments and multilateral institutions in the area of debt management. 

Chapter

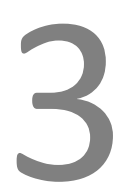

Reforms for Debt Relief 
The rapid increase in the debt profiles of Nigeria and Rwanda in the 1970s and 1980s can be attributed to a multiplicity of institutional factors at international and national levels. The changes in the international economic system, and the policies prescribed by multilateral agencies established the framework for the provision of debt finance, and dictated economic and institutional reforms intended to improve the economies of borrower countries. At domestic level, it was the political, economic and social arrangements of borrower countries that determined the sources, composition and utilisation of debt finance. These arrangements, or governance systems encouraged the irresponsible acquisition of debt and the misuse of debt finance in the 1970s and 1980s. By the 1990s, outstanding debt obligations accumulated to the extent that the bulk of public resources were directed towards the repayment of debt. As a result, Nigeria and Rwanda sought and obtained relief on external public debt in 2005.

This chapter seeks to answer the second research question, i.e., in what ways did the Governments of Nigeria and Rwanda deploy laws and institutions as instruments for debt relief? The adoption of the good governance agenda and the MDGs by IFIs, as well as the successful Jubilee debt campaign led to a wave of policy and institutional reforms within IFIs and the governance systems of developing countries. Policy reforms were centred on the integration of developmental objectives and good governance into the agenda of the IMF, the World Bank and governments of developing countries. Also, institutional reforms were prescribed by IFIs to enhance the capacity of governments to deliver developmental outcomes. Naturally, reforms underpinned by the 'governance agenda' extended to the introduction of laws to manage public finance, particularly the debt management systems of governments. Furthermore, these laws function as tools for economic management, as they stipulate debt management functions to be adopted and implemented by government institutions.

Thus, this chapter begins with an overview of the policy reforms undertaken within the IMF and World Bank in support of debt relief for developing countries. Thereafter, reforms, as prescribed by these IFIs, and implemented by the Governments of Nigeria and Rwanda to obtain debt relief are outlined. Specifically, budgetary reforms underpinned by legislation, and the resultant institutional systems for managing public finance are presented. Economic outcomes are the result of numerous and dynamic variables, which cannot be attributed solely to reforms or government intervention in the economy or policy environment. As such, this chapter concentrates on those reforms of public finance, particularly debt management, which sought to use law as a tool to supervise government functions, regulate government behaviour, and create policy environments conducive to the pursuit of stated economic objectives. The examination of reforms implemented in Nigeria and Rwanda reveal the influence of World Bank and IMF policy on the economic performance of borrower countries. Also, the reforms present the ideological agenda of the Bank and the Fund, and how these are manifested in the institutional and legal systems of borrower countries. Finally, the chapter concludes with an analysis of the ways by which laws and institutions were placed to interact with, and regulate governments in the management of public debt. 


\subsection{International Finance Institutions and Policy Reforms for Debt Relief}

In the 1990s, the work of NIE and the adoption of the governance agenda by IFIs positioned governments as the drivers of economic development. Concurrently, the successful Jubilee 2000 campaign for debt relief was premised on the argument that debt burdens impeded development. The campaign argued that developing countries were faced with a choice: to either service debt obligations, or to spend on critical infrastructure and social services. This decade also birthed the MDGs (2000-2015), which articulated the shared global objectives of poverty eradication and improvements in the quality of social conditions. Additionally, the Goals were set as a development benchmark, i.e., the economic and social progress of countries were measured against the MDGs. Furthermore, the MDGs fostered cooperation between governments, multilateral agencies and social sectors as they served to harness resources, and coordinate efforts of these actors towards common goals (See 2.5).

The World Bank and the IMF are the institutions which manage the international finance system, even as they spearhead discourse and policy approaches within international development practice (See 2.1 and 2.2). According to Oxfam, "the Fund's view of what defines the macroeconomic stability of a country is the authoritative one for all development partners. Given this, the Fund could and should be playing a dynamic, proactive role in establishing the financing conditions for achieving the Millennium Development Goals" (Oxfam, 2003). Joseph Hanlon goes further to describe the World Bank as an international debt collector, and states that "all foreign aid and all debt relief is conditional on countries that have Bank and Fund programmes" (Hanlon, 1998, p. 489).

The World Bank and IMF recognised that debt burdens were an impediment to the progress of developing countries, and that debt relief was necessary to release resources for investment into development needs. From the late 1980s, both institutions provided technical assistance and endorsement for debt relief mechanisms offered by commercial creditors, e.g., the Toronto terms (1988), London Terms (1991), Naples terms (1994), and Lyons terms (1996) (See 2.4.4.). To qualify for debt relief under these mechanisms, borrower countries were required to implement an IMF SAP. In 1996, the World Bank and IMF further expanded debt relief mechanisms through the Heavily Indebted Poor Countries (HIPC) Initiative.

\subsubsection{The Heavily Indebted Poor Countries Initiative}

The HIPC Initiative was launched by the IMF and World Bank "with the aim of ensuring that no poor country faces a debt burden it cannot manage" (International Monetary Fund, 2016, p. 1). The achievement of this aim requires that debt is reduced to sustainable levels, measured by the capacity of a country to satisfy current and future debt obligations in full, without resort to rescheduling, accumulation of arrears, or compro- 
mise of its economic growth (International Development Association and International Monetary Fund, 2001). In 1997, the then General Counsel of the World Bank, Ibrahim Shihata, stated that the HIPC was intended for the resolution of external public debt owed to official creditors. The World Bank had identified 20 countries suffering from unsustainable debt. 80 per cent of this debt was owed to official creditors, 58 per cent of which was owed to foreign governments and government agencies (bilateral debt), and the remainder 22 per cent to international financial institutions (multilateral debt) (Shihata, 1997).

In practice, the HIPC Initiative retained features of SAPs, i.e., borrower countries were required to demonstrate good policies as determined by the IMF and World Bank, and implement structural reforms to be eligible for concessional loans from the IMF and World Bank. Isar (2012) states that reforms were contingent on the ability of borrower countries to:

1) Secure a flow-rescheduling agreement with Paris Club Creditors, which would be applicable when there was a reduction in stock-of-debt over a 3year period;

2) Maintain a good track record of meeting IMF arrangements and rescheduling agreements;

3) Seek comparable debt terms from private and bilateral creditors outside the Paris Club;

4) Seek bilateral debt relief in form of official development assistance.

Also, the SAP emphasis on good macroeconomic performance, as assessed by the IMF, was retained in the HIPC Initiative. Countries reached the decision point, i.e., eligibility to participate in the Initiative after they maintained macroeconomic policies supported by IMF programs and loans for 6 years. To reach the completion point, at which they would receive a permanent reduction in debt stock, countries were required to maintain good policies for a further 3 years (Birdsall, et al., 2002). While up to 80 per cent of the Net Present Value (NPV) of a country's external debts could be relieved by Paris Club Creditors, exact amounts to be relieved were to be decided on a case by case basis (Isar, 2012). According to the United Nations Development Program (UNDP), NPV is an estimate of all annual debt payments in the coming years and valuation according to current rates (United Nations Development Program, 2003). Debt sustainability analysis was conducted using a framework which incorporated elements including: an NPV of debt-to-exports ratio in the range of 200-250 per cent, a debt service ratio in the range of 20-25 per cent. Countries with a large export base were assessed on the additional indicators of: a revenues-to-GDP ratio above 20 per cent, an exports-to-GDP ratio above 40 per cent and an NPV of debt-to-revenues ratio of 280 per cent (International Development Association and International Monetary Fund, 2001). The criteria and indices by the World Bank and the IMF assessed debt sustainability under the HIPC Initiative are presented in the table below. 
Table 7: Debt Sustainability Analysis of the HIPC Initiative

\begin{tabular}{ll}
\hline Element & Assessment \\
\hline Debt Relief & $\begin{array}{l}\text { Up to } 80 \% \text { of NPV of External Debt (Exact value decided on case-by-case } \\
\text { basis) }\end{array}$ \\
NPV of debt-to-exports ratio & $200-250 \%$ \\
Debt service ratio & $20 \%-25 \%$ \\
Revenues- to-GDP ratio & Above $20 \%$ \\
Exports to-GDP & Above $40 \%$ \\
NPV of debt-to-revenues ratio & $280 \%$ \\
\hline
\end{tabular}

However, a few years after the launch of the Initiative, it was evident that the original framework would not enable the permanent exit of HIPC countries from repeated debt reschedulings (G-24, 2003). The IMF stated that "early progress with the Initiative did not meet public expectations, with seven countries qualifying for assistance in the first three years" (International Monetary Fund, 2000). In response, the Enhanced HIPC, or HIPC II, was launched in 1999 to provide deeper and broader relief, faster relief, and a stronger link between debt relief and poverty reduction (World Bank, 2004). The Enhanced HIPC introduced 'interim debt relief' between decision point and completion point, in order to reduce debt service costs from the commencement of participation in the Initiative. Also, completion points were made 'floating'- to be determined by implementation of reforms to aid poverty reduction and growth, rather than by specific duration (International Monetary Fund, 2000).

Importantly, the Enhanced HIPC addressed poverty reduction through the inclusion of the requirement that countries present a Poverty Reduction Strategy Paper (PRSP). PRSPs describe how "macroeconomic, structural, and social policies and programs can promote growth and reduce poverty, and outline external financing needs and the associated sources of financing" (International Monetary Fund, 2017). Also, developmental issues are addressed: country PRSPs speak to poverty diagnostics, targets and indicators, monitoring and evaluation, as well as priority public actions, and planned improvements in public expenditure programs and public expenditure management systems (International Monetary Fund, 2016). In addition, the PRSP provides operational frameworks for domestic policies and development assistance (International Labour Organization, 2006). The PRSP is supported by the Poverty Reduction and Growth Facility (PRGF), also introduced in 1999 and which replaces the Enhanced Structural Adjustment Facility (ESAF), which had supported the original HIPC. Through the ESAF, the IMF provided concessional loans to low-income countries up to a maximum of 140 percent of its IMF quota over 3 years. These loans were provided at the rate of 0.5 per cent, repayable over a period of 5 to 10 years (International Monetary Fund, 2004). In contrast, while it retains the rate of 0.5 per cent and the repayment duration of the ESAF, the PRGF dispensed with the quota requirement. Instead the facility is directly linked to 
the provisions of the PRSP submitted by countries, (International Monetary Fund, 2009).

In 2005, the World Bank and IMF, introduced an additional mechanism- the Multilateral Debt Relief Initiative (MDRI) to alleviate debt burdens and assist countries as they worked towards the achievement of the MDGs. Through the MDRI, the IMF, World Bank and African Development Fund offered 100 per cent relief on eligible debt (International Monetary Fund, 2016).

To obtain debt relief under the HIPC and MDRI mechanisms, borrower countries pass through two milestones. Firstly, at the decision point, the World Bank and IMF determine whether countries are eligible for debt relief under strict criteria, which the International Monetary Fund (2016) sets out as:

1) Eligibility to borrow from the IDA

2) Face an unsustainable debt burden

3) Have a track record of reform and sound policies through IMF and World Bank supported programs

4) Have developed a Poverty Reduction Strategy Paper

According to the United Nations Development Program (UNDP), under the Enhanced HIPC, the evaluation of debt sustainability is simplified and calculated on the basis of 1) whether NPV of external debt exceeds 150 per cent of export revenues, or 2) whether NPV of external debt exceeds 250 per cent of budget revenue (in the event that exports of goods and services exceed 30 per cent of GDP and budget revenues exceed 15 per cent of GDP) (United Nations Development Program, 2003).

If a country satisfies these criteria, the international community commits to levels of debt relief, some of which may be provided upon commencement of the HIPC program. Also, the recipient countries commit to the implementation of policy reforms intended to improve economic standing and reduce poverty. Bhattacharya (2004) observes that in addition to debt relief, the HIPC Initiative seeks to support policy and institutional reforms which should form the foundation for sustained growth and accelerated poverty reduction. Secondly, countries reach a completion point, at which they exit the program, and receive the balance of debt relief promised by the international community at the decision point. Countries exit the HIPC Initiative if they present a 1) further track record of good performance under programs supported by loans from the IMF and the World Bank, 2) satisfactory implementation of key reforms agreed at decision point, and 3) adoption and implementation of the PRSP for a minimum of one year (International Monetary Fund, 2016). By 2014, of the 39 countries eligible for debt relief through the HIPC, 36 received full debt relief worth US\$99billion after reaching completion points. 3 countries are yet to reach their completion points (World Bank, 2014; International Monetary Fund, 2016). The HIPC, Enhanced HIPC and MDRI are the mechanisms by which the majority of developing countries obtained relief on public debt 
between 1996 and 2014. The table below outlines the different mechanisms of the three systems:

Table 8: $\quad$ IMF and World Bank Debt Relief Mechanisms 1999-2014

\begin{tabular}{|c|c|c|c|}
\hline & HIPC & Enhanced HIPC & MDRI \\
\hline Objective & $\begin{array}{l}\text { Reduce external debt to } \\
\text { sustainable levels }\end{array}$ & $\begin{array}{l}\text { To ensure deep, broad and fast } \\
\text { debt relief and thereby } \\
\text { contribute toward growth, } \\
\text { poverty reduction, and debt } \\
\text { sustainability in the poorest, } \\
\text { most heavily indebted countries. }\end{array}$ & $\begin{array}{l}\text { To provide additional } \\
\text { support for HIPC countries } \\
\text { to achieve the MDGs }\end{array}$ \\
\hline Qualification & IDA-only & IDA-only & $\begin{array}{l}\text { HIPC countries which have } \\
\text { reached completion point }\end{array}$ \\
\hline $\begin{array}{l}\text { Extent of and } \\
\text { Prerequisite for } \\
\text { Debt Relief }\end{array}$ & $\begin{array}{l}\text { - Up to } 80 \text { per cent of the } \\
\text { Net Present Value (NPV) } \\
\text { external debts }\end{array}$ & $\begin{array}{l}\text { - Interim Debt Relief between } \\
\text { decision point and completion } \\
\text { point } \\
\text { - Poverty Reduction Strategy } \\
\text { Paper }\end{array}$ & $\begin{array}{l}100 \text { per cent debt relief on } \\
\text { eligible debt }\end{array}$ \\
\hline Finance Facility & $\begin{array}{l}\text { Enhanced Structural } \\
\text { Adjustment Facility }\end{array}$ & $\begin{array}{l}\text { Poverty Reduction and Growth } \\
\text { Facility }\end{array}$ & \\
\hline Decision Point & $\begin{array}{l}\text { - Debt sustainability } \\
\text { analysis by IMF and World } \\
\text { Bank } \\
\text { - Good macroeconomic } \\
\text { policies and IMF programs } \\
\text { for } 6 \text { years }\end{array}$ & $\begin{array}{l}\text { - Debt sustainability analysis by } \\
\text { IMF and World Bank } \\
\text { - PRSP }\end{array}$ & $\begin{array}{l}\text { Completion of Enhanced } \\
\text { HIPC cycle }\end{array}$ \\
\hline Completion Point & $\begin{array}{l}\text { Implementation of IMF- } \\
\text { supported macroeconomic } \\
\text { policy programs and loans } \\
\text { for } 3 \text { years }\end{array}$ & $\begin{array}{l}\text { Floating: } \\
\text { - Good economic policies and } \\
\text { performance } \\
\text { - Successful implementation of } \\
\text { reforms agreed at decision point } \\
\text { Implementation of PRSP for } 1 \\
\text { year }\end{array}$ & $\begin{array}{l}\text { Completion of Enhanced } \\
\text { HIPC cycle }\end{array}$ \\
\hline $\begin{array}{l}\text { Beneficiary } \\
\text { Countries }\end{array}$ & 7 countries & 36 Post-decision HIPC countries & $\begin{array}{l}36 \text { Post-HIPC completion } \\
\text { countries }\end{array}$ \\
\hline $\begin{array}{l}\text { Debt Eligible for } \\
\text { Relief }\end{array}$ & $\begin{array}{l}\text { Up to } 80 \text { per cent of NPV of } \\
\text { external public debt owed } \\
\text { to official and multilateral } \\
\text { creditors }\end{array}$ & $\begin{array}{l}\text { External public and publicly } \\
\text { guaranteed debt is reduced to } \\
\text { the HIPC Initiative thresholds, as } \\
\text { calculated at the time of the } \\
\text { decision point }\end{array}$ & $\begin{array}{l}\text { Debt disbursed before end- } \\
\text { December } 2004 \text { (IMF, AfDF } \\
\text { and the IADB) and end- } \\
\text { December } 2003 \text { (IDA) and } \\
\text { still outstanding at the time } \\
\text { of qualification (after HIPC } \\
\text { Initiative debt relief) is } \\
\text { cancelled }\end{array}$ \\
\hline $\begin{array}{l}\text { Participating } \\
\text { Creditors }\end{array}$ & $\begin{array}{l}\text { Bilateral, official and } \\
\text { multilateral creditors. }\end{array}$ & $\begin{array}{l}\text { All multilateral, official bilateral } \\
\text { and commercial creditors }\end{array}$ & $\begin{array}{l}\text { International Development } \\
\text { Association (IDA), } \\
\text { International Monetary } \\
\text { Fund (IMF), African } \\
\text { Development Fund (AfDF), } \\
\text { and Inter-American } \\
\text { Development Bank (IADB) }\end{array}$ \\
\hline
\end{tabular}

Source: (World Bank , 2016) 
The HIPC and MDRI can be described as reforms of instruments used by the World Bank and IMF in their engagements with borrower countries. These instruments display the change in rationale and objective of these institutions in the area of debt management, and are a response to the criticisms levelled at SAPs. In the 1970s and 1980s, technical assistance was premised on the objective of debt repayment, and structural adjustment programs sought the correction of weaknesses in developing economies, as determined by IFIs. These programs were criticised for their interference in the economies and political arrangements of sovereign states, and for their blanket approach to economic liberalization, which did not consider the particular circumstances and capacities of borrower countries (See 2.3). Importantly, the focus on debt repayment and rectification of economic imbalances did not account for social problems which emanated from the reduction of government participation in the economy (See 2.2.1 and 2.2.2). Conversely, the Enhanced HIPC and MDRI support the capacity and commitment of countries towards the achievement of developmental goals, particularly the MDGs. Also, these instruments can be interpreted as an attempt to reduce impositions by IFIs on borrower countries. The IMF states that PRSPs are intended to enable country-driven, results-oriented, comprehensive, partnership-based and long-term approaches to the achievement of developmental objectives (International Monetary Fund, 1999). This approach is a means to ensure that strategies are tailored to the present realities and ambitions of countries. Additionally, debt relief, rather than structural adjustment is an incentive which steers countries towards completion, rather than abandonment of the program. These reforms notwithstanding, criticisms of the World Bank and IMF persist, often from international nongovernmental organizations and the scholarly community. These criticisms range from arguments that reforms of instruments are insufficient to achieve developmental impact, to allegations that the World Bank and IMF actively impede the development of poor countries. These criticisms are outlined in the next section.

\subsubsection{Criticisms of the Heavily Indebted Poor Countries Initiative}

The IMF claims that HIPC eligible countries spend on the average, up to 5 times more on social services, than they do on debt service payments (International Monetary Fund, 2016). However, Todd Moss has argued that this claim is not tenable in light of the fact "aid inflows average nearly 60 per cent of total public expenditure in 14 sub-Saharan African countries" (Moss, 2006, p. 289). Also, Moss noted that in 2004, 14 African HIPCs paid, on average, US\$19million to the IDA, while they received US\$204million in new IDA credits, and US\$959million in total aid. Additionally, he asserted that the MDRI does not deliver financial windfall to countries, as savings from forgiven debt are subtracted from future IDA flows (Moss, 2006). Similarly, in a 2004 publication, FONDAD noted that savings from debt relief under the HIPC mechanism are subject to negotiations with the 
IMF and World Bank, and thus may not necessarily be directed towards poverty reduction (Martin, 2004).

Country-ownership of the debt relief process is successfully challenged on several fronts; firstly, country ownership is limited to the preparation of the strategy document, i.e., the PRSP. It is the World Bank and IMF that establish the thresholds by which countries qualify for debt relief, and the extent of relief to be provided. Secondly, the HIPC has resulted in increased surveillance of political and economic processes of borrower countries, thereby increasing the depth of conditionality. Harrison Graham alleges that "conditionality based structural adjustment lending has been replaced with another reform agenda, perhaps best summarised as governance" (Harrison, 2004, p. 125). HIPC status is dependent on external, i.e., donor evaluations of indebted countries, and given only to those countries eligible to borrow from the IDA (Harrison, 2004). The PRSPs are a comprehensive presentation of the 'as-is' political, economic, social arrangements of countries, and a statement of undertaking for planned reforms of these arrangements.

Furthermore, the metrics by which debt sustainability is assessed does not bear any direct correlation with poverty reduction. Jeffrey Sachs argues that it is possible for a country to have sustainable debt as defined by the IMF and World Bank, and its people affected by very high levels of hunger and disease. He states that "with creditors determining what was or was not sustainable, the flagrantly excessive demands on the impoverished debtor nations could not be challenged in the corridors of power" (Sachs, 2002 , p. 277). Also, NPV calculations are based on forecasts of future economic positions that are impossible to know. Hanlon (1998) criticises the metrics by which debt relief is assessed and granted under the HIPC, on the argument that IFIs are insincere about debt relief, and have constructed the international financial system to ensure that borrower countries remain in perpetual debt. He refers to the work of economists such as Charles Kindleberger to surmise that lenders do not want debt repaid. Instead, lenders want for debt to remain on the books, and to be serviced if possible. If debts will not be serviced, then lenders try to organise an orderly exit. Importantly, he asserts that lenders prefer for debt to persist, in order to exert maximum leverage over debtors. As an example, Hanlon presents the case of Mozambique under the HIPC process: pre-and post HIPC, its average annual debt service payment was US\$113million (Hanlon, 1998). Pettifor and Greenhill corroborate this position as they argue that the term debt relief, as used by the IMF and the World Bank, is a simply a euphemism for debt-rescheduling. They go further to claim that the HIPC Initiative is a failure which does not seek development, but a mechanism to force countries to adopt IMF conditionality in order to ensure the transfer of assets from debtor countries to creditor countries (Pettifor \& Greenhill, 2002). The table below summarises the arguments against the HIPC Initiative: 
Table 9: Criticisms of WB/IMF HIPC Claims

\begin{tabular}{ll}
\hline IMF/World Bank Claim & Criticism \\
\hline HIPC releases resources for development in & Debt relief sums are not significant when considered against \\
borrower countries & other sources of inflow, i.e., aid and credit. \\
& - Use of resources or savings gained from debt relief is \\
& determined by IMF/World Bank. Resources can be retained in \\
& IFIs or spent on other projects. \\
HIPC allows borrower countries own & - Benchmarks are determined by IMF/World Bank. Country \\
reforms implemented for debt relief & qualification for HIPC are assessed by staff according to criteria \\
HIPC reduces debt to sustainable levels & - Set. \\
& redustainable debt analysis does not impact upon poverty \\
& Multilateral agencies do not seek debt sustainability, but debt \\
& rescheduling at best, and permanent indebtedness at worst. \\
\hline
\end{tabular}

These criticisms notwithstanding, the HIPC Initiative is an influential mechanism, which has served as the system by which many developing countries obtained relief on external debts. For the preparation of PRSPs, the Governments of Nigeria and Rwanda undertook comprehensive evaluations of their economies, and identified weaknesses which inhibited the capacity of the public sector to deliver developmental benefits. Thereupon, the PRSPs guided the adoption and implementation of wide-ranging reforms in both countries. The following sections outline reforms adopted and implemented by the governments of Nigeria and Rwanda in the area of public debt management.

\subsection{Institutional and Legal Reforms driven by the Poverty Reduction and Strategy Papers}

During the debt crisis of the 1980s, IFIs attributed the debt burdens of Nigeria and Rwanda to poor governance, particularly the weak capacity of the governments of both countries to manage economic systems (See 2.2). This position is validated in the context of external debt, as it can be argued that it was weaknesses in the public sector that, at country level, caused the accumulation of debt. It can be argued that both countries did not possess the requisite policies and well-functioning institutions to drive the development of their economies through debt finance, or to effectively manage reductions to national income which originated in the international economic system.

PRSPs can be considered as mechanisms utilised by the Governments of Nigeria and Rwanda to execute reforms which would change the 'rules of the game' (See 1.2.4), or the environment in which economic activities would be undertaken, and establish a system to ensure that outcomes were achieved. The PRSPs developed by the governments of Nigeria and Rwanda reflected the good governance agenda and institutional thinking which had come to dominate development economics from the middle of the 1990s. 
Furthermore, the role of government in ensuring macroeconomic stability was emphasized in PRSPs. To ensure macroeconomic stability, the Governments of Nigeria and Rwanda undertook a number of reforms to improve the management of public finance. National budgets, underpinned by legislation and managed by public sector institutions became the system for determining the sources of, and utilisation of government revenue. Through budget-related reforms, the Governments of Nigeria and Rwanda sought to introduce transparency, predictability and accountability into public finance systems.

The use of legal instruments to manage public finance is a model adopted from budgetary legislations and regulations used by western economies, particularly those of federal systems, i.e., where public finances are managed by several hierarchies and units of government. A common feature of these budgetary legislations are reference values, or benchmarks by which economic health and debt sustainability are measured. For example, the Stability and Growth Pact of the European Union was established in 1997 to uphold fiscal responsibility, which is considered fundamental (by EU countries) for the sustainability of public finances and for financial stability in the European Union (European Commission, 2015). The Pact is underpinned by Article 136 of the Treaty on the Functioning of the European Union (2007), which empowers the Council to adopt measures to coordinate and conduct surveillance on budgetary discipline of, and provide economic policy guidelines, to those Member States which have adopted the Euro currency. Sustainable debt is presented as critical to financial stability: Article 126(1) of the Treaty states that Member States shall avoid excessive deficits. Compliance is calculated with reference to a matrix, which measures public debt levels against GDP. This matrix also prescribes actions for individual, and all member states in the event of negative changes in the financial position of a Member state. Collignon (2012) gives these reference values as i) ratio of planned or actual government deficit at a maximum of 3 per cent of GDP, and b) ratio of government debt to GDP is capped at a reference value of 60 per cent.

Fiscal Rules, particularly limits and constraints on debts, borrowing and fiscal deficits as used in federal systems, particularly India, Brazil and the USA, are thought to contribute to transparency and accountability in the management of public finances (Yelwa, 2010). The PRSPs implemented in Nigeria and Rwanda embrace the necessity of fiscal rules, embedded in the form of legislation. According to Ighodaro Omoigui of the World Bank, budget laws and tax reforms of the HIPC process were used to prevent the buildup of unsustainable debt situations (Omoigui, 2017). Similarly, Ushie (2010) states that Fiscal Responsibility Acts (FRAs) are intended to subject governments to rules which stipulate transparent fiscal and budget practices. She goes further to discuss two types of FRAs, i.e., numerical rules which guide and benchmark performance against quantitative indicators, and procedural rules which establish transparency, coverage and accountability requirements (ibid).

The following sections present budget-related reforms implemented by the Governments of Nigeria and Rwanda. It is important to note that is difficult to evaluate the 
effect of reforms on economic outcomes, as these are the result of a variety of factors. However, the effect of reforms on the functionality of government institutions and processes of economic management can be investigated. Also, it is possible to evaluate the effects of reforms in the transformation of the policy environment and behaviour of economic actors. In this case, the effectiveness of legislation and institutions in regulating government behaviour in the area of public finance will be examined.

\subsection{Nigeria Poverty Reduction Strategy Paper}

While Nigeria did not satisfy the IDA-only criterion, and thus could not participate in the HIPC program, its debt relief process was modelled closely on the HIPC. In 2003, the Federal Government adopted a 4year development plan titled National Economic Empowerment and Development Strategy (NEEDS) (Peterside, 2003). The NEEDS Strategy Paper, titled 'Meeting Everyone's Needs' was modelled on the PRSP, and served to articulate Nigeria's process of development anchored by a clear vision, sound values and enduring principles. NEEDS was the first time that a development plan was based on an "investigation of how ordinary Nigerians live, and underpinned by a "sound knowledge of the causes of poverty" (Nigerian National Planning Commission, 2004, pp. xii-xiii). NEEDS proposed bold steps to achieve macroeconomic stability and more efficient use of resources to grow the economy (Nigerian National Planning Commission, 2004).

In devising an economic strategy for Nigeria, the National Planning Commission acknowledged that the root of Nigeria's economic problems lay in the Import Substitution Industrialization model embraced in the 1970s. This model expanded the role of government in the economy, which fostered corruption and mismanagement: "for decades, Nigeria's economy was characterised by the growing dominance of the public sector, over reliance on a single commodity (oil) and the pursuit of a high import dependent, import substituting industrial strategy" (Nigerian National Planning Commission, 2004, p. 52). Also, the Commission attributed the weaknesses of government institutions to military dictatorships. NEEDS was intended to correct these foundational problems through a three-pronged reform agenda which would 1) Empower People 2) Promote Private Enterprise and 3) Change the Ways by Which Government Worked. The developmental thrust was emphasized through budgetary allocation; sectors key to poverty reduction- health, education, electricity, roads and water received highest priority of resource allocation, which amounted to over 60 per cent of the capital budget for 2004. The implementation of NEEDS was estimated to cost up to US\$4.5billion, to be financed by the Nigerian Government, and supported by Official Development Assistance which the government sought from IFIs. The NEEDS model was designed to reward success of reforms, as the government expected development agencies to direct their interventions into areas of good performance. Additionally, the government expected private-sector related reforms to attract up to US\$1.5billion in foreign direct 
investment. Through reforms, the Nigerian Government expected to foster economic and social development, even as it avoided previous mistakes of direct interventions in the economy (Nigerian National Planning Commission, 2004).

NEEDS was described by the then President of Nigeria, Olusegun Obasanjo as a home-grown reform program. According to President Obasanjo, the characteristic of national ownership, combined with results already visible would ensure sustainability beyond 2007. The document presented Nigeria's case for debt relief, which was premised on the argument that "only substantial debt relief will allow Nigeria to pursue a meaningful development programme" (Nigerian National Planning Commission, 2004, p. 116). This assertion was based on a 2002 investigation of the IMF, which found that the resolution of Nigeria's debt problem would necessitate the rescheduling of up to 67 per cent of NPV of debt, followed by a reduction of the NPV of up to 67 per cent of stock-of-debt. The country's annual debt service was estimated at US\$3billion which was made at an immense cost to social development: debt service payments made between 2001 and 2003 were 5 times as high as the recurrent Federal Government budgetary allocation to education, and 6 times as high as the recurrent budgetary allocation to health. The document affirmed the correlation between reforms and debt relief through its optimistic assertion that reform implementation, policy consistency, as well as improvements in the management of public resources would result in substantial reduction in external debt service payments. Debt relief would then allow increased spending in the social sectors, particularly health, education, water and infrastructure (Nigerian National Planning Commission, 2004). Ngozi Okonjo-Iweala, the then Minister of Finance notes that Nigeria was the first country to have a home-grown program articulated as a Policy Support Instrument (PSI) approved by the IMF board (in 2005). NEEDS was the first time that the IMF had served as an institutional monitor for a reform program conceived, designed and implemented by a borrower government. She states that the reform program was implemented for 15 months, after which the government approached the Paris Club for debt relief (Okonjo-Iweala, 2012). In 2005, the Paris Club welcomed the ambitious reforms implemented by Nigeria and entered into a debt relief agreement with the government of Nigeria. Under the agreement, the Paris Club provided debt reduction under the Naples Terms, and allowed Nigeria to buy back the remainder of eligible debts. This was implemented in two (2) stages:

1) The government of Nigeria cleared its arrears (US\$6.3billion) with the Paris Club on all debts, and obtained a 33 per cent cancellation of eligible debts; and

2) After a review of implementation of the PSI, i.e., NEEDS in 2006, the government cleared amounts due (US\$6.1billion), obtained relief on further 34 per cent on eligible debts, and the bought back the remainder of debts.

Through this agreement, Nigeria obtained debt cancellation estimated at US\$18 billion (including moratorium interest) which represented an overall cancellation of about 60 per cent of its debt to the Paris Club of around US\$30 billion. The Paris Club stated that 
its 'exceptional' treatment of Nigeria's debt offered a "fair, sustainable and definitive" solution to Nigeria and her Paris Club Creditors (Paris Club, 2005).

In 2007, the IMF published a progress report on NEEDS, in which it noted that implementation had been remarkable, and that results had surpassed expectations. However, the report noted that the government had not yet reached the goals it set out in the areas of poverty reduction and employment generation (International Monetary Fund, 2007). This position is corroborated by Eze (2014), who argues that living conditions worsened as a result of NEEDS. Similarly, Ogundele et al (2011) assert that upon termination of the program in 2007, there was little to show in terms of targeted achievement. However, the IMF identified areas of success, including macroeconomic stabilisation, budgetary process improvements, banking consolidation, civil service reforms, emergence of the non-oil sectors, enactment of new legislations and some improvements in development indicators (health and education) (International Monetary Fund, 2007).

\subsubsection{Implementation of the National Economic Empowerment and Development Strategy}

An implementation, monitoring and evaluation framework which reflected the political and administrative architecture of governance in Nigeria was integrated into NEEDS. The three levels of Executive Government- Federal, State and Local, were responsible for direct implementation of NEEDS. Also, the implementation framework required cooperation between the Executive and Legislative Arms of Government as outlined below;

a) Executive:

i. State and Local Governments were encouraged to create State Economic Empowerment and Development Strategies (SEEDS), and Local Economic Empowerment and Development Strategies (LEEDS) respectively. Local Governments especially were encouraged to develop "medium-term development programmes, specifying programmes, benchmarks and targets, deliverables, timelines, and implementation guides" (Nigerian National Planning Commission, 2004 , p. 103). Note that in the federal system of government in Nigeria, the 36 State Governments control over half of national revenue (Yelwa, 2010), and retain independence to determine expenditure priorities and accumulate debt (Ushie, 2010). Public revenue, from all sources, e.g., sale of crude oil and taxes, is distributed from the Federal Account Allocation Committee (FAAC) to the Federal, State and Local Governments according to an agreed formula. In 2016, public revenue was allocated as follows: the Federal Government was allocated 54 per cent, State Governments (36) were assigned 26 per cent, and Local Governments (774) shared 20 per cent (Salaudeen, 2016). 
ii. NEEDS-related activities were formulated and overseen by the Federal Executive Council, (composed of the President, Vice-President and Cabinet Ministers), and the National Economic Council (comprising State Governors, the Central Bank and the Vice-President). Both Councils were required to present periodic reports to the National Assembly.

iii. The National Planning Commission (Federal Agency) was the designated secretariat of NEEDS, and supervised the Service Delivery Unit. Similarly, the Central Bank and Federal Ministry of Finance were responsible for mobilization and supervision of Federal Agencies responsible for the implementation of aspects of NEEDS.

iv. An Independent Monitoring Committee, was established to monitor and evaluate progress. This committee, chaired by the Secretary to the Government of the Federation, comprised representatives of the Private Sector and Government Agencies. On a quarterly basis, this Committee was mandated to inform the National Assembly (legislature) of its findings, and report to the Presidency and National Economic Council, even as it coordinated a Peer-Review Mechanism which incorporated the private and social sectors into the monitoring and evaluation process.

\section{b) Legislature:}

The National Assembly, i.e., the House and Representatives (lower chamber) and Senate (upper chamber), was to contribute to the implementation of NEEDS through:

i. Enactment of relevant laws necessary for the implementation of NEEDS, and responsibility to ensure that budgetary appropriations are consistent with objectives of NEEDS;

ii. Supervision of relevant Agencies to ensure that NEEDS is implemented; and

iii. Public awareness as to NEEDS and mobilization of public support

\subsubsection{Budget Reform in Nigeria: The Fiscal Responsibility Act 2007}

The PRSP states that budgeting process had "reached the point of near collapse" prior to the transition to civilian government in 1999 (Nigerian National Planning Commission, 2004, p. 17). To correct this, the Fiscal Responsibility Act 2007 was enacted to achieve a three (3) fold purpose:

1) Provide for prudent management of the nation's resources, ensure long-term macroeconomic stability of the national economy,

2) Secure greater accountability and transparency in fiscal operations within a medium-term fiscal policy framework, and

3) Establish the Fiscal Responsibility Commission to ensure the promotion and enforcement of the nation's economic objectives; and for related matters. 
Nigeria's budgetary legislation introduced both quantitative and procedural rules for the management of public finances. Quantitative rules include the oil-based rule, the size of fiscal deficit, limits of public debt, and conditions/qualifications for public borrowing. Procedural rules cover government adherence to medium-term fiscal framework, governance of the budget process, savings and asset management, provisions on audits and reporting requirements for government, and transparency and accountability standards (Ushie, 2010). Organized into 13 Parts and 57 Sections, the Act seeks to establish the formulae and framework by which the Federal Government manages financial resources. An independent institution, the Fiscal Responsibility Commission was created by this legislation to supervise budget creation and implementation, even as it was empowered to monitor government compliance with the provisions of the Act. Additionally, the Act assigns functions to and creates obligations for other Agencies of Government and the National Assembly. To illustrate, S44(5) FRA 2007 mandates the Debt Management Office to "maintain comprehensive, reliable and current electronic database of internal and external public debts, guaranteeing public access to the information". Similarly, S30(1) of the FRA 2007 obligates the Budget Office to "monitor and evaluate the implementation of the Annual Budget, assess the attainment of fiscal targets and report there on a quarterly basis to the Fiscal Responsibility Council and the Joint Finance Committee of the National Assembly". The Fiscal Responsibility Act was amended in 2011 to increase the powers of the Commission to enhance the execution of its functions. The provisions concerning the budget and debt management are not affected or altered by the Amendments. Also, the Fiscal Responsibility Commission operated until a 2014 administrative (downsizing) reform of the public sector, when its functions were absorbed by the Revenue Mobilisation, Allocation and Fiscal Commission (Premium Times, 2014).

\subsubsection{The Fiscal Responsibility Act and Government Borrowing}

A review of the provisions reveals that the government of Nigeria sought to avoid the outcomes which emanated from the borrowing practices of the 1970s and 1980s. Parts IX (SS41-43) and X (SS44-47) of the Act stipulate the processes and purposes by which all tiers and arms of government may acquire and manage debt.

\section{Debt Acquisition and Use}

S41(1)(a) of the Act states as follows: "Government at all tiers shall only borrow for capital expenditure and human development, provided that, such borrowing shall be on concessional terms with low interest rate and with a reasonably long amortization period subject to the approval of the appropriate legislative body where necessary". In effect, this section confines the purposes for which the Government may borrow to Capital Expenditure and Human Development. The introduction of human development as a condition for borrowing seems to compel the government to ensure that borrow- 
ing is undertaken for the betterment of the Nigerian people. This is in direct contrast to the approach of the 1970s and 1980s, where the government could borrow for any purpose it determined necessary. Importantly, the government is restricted to seeking concessional loans provided at low interest rates. This condition may be construed as a reaction to the rapid escalation of obligations which arose from the terms of commercial loans of the Paris Club in the 1970s and 1980s. Should the government satisfy requirements for borrowing as stated in this section, it must then secure the approval of the legislature, i.e., the National Assembly prior to debt acquisition.

However, S41(2) provides a caveat to the sections above, as it allows the Federal Government obtain loans from the capital market, should such an undertaking receive approval from the National Assembly. This section suggests that State Governments and Government Agencies are precluded from obtaining commercial loans, and are restricted to obtaining concessional loans. Also, it would be assumed that loans obtained from the capital market would be subjected to the justifications of S41(1)(a), i.e., loans should be for the purposes of capital expenditure and human development, prior to approval by the National Assembly.

The FRA 2007 requires that public sector borrowers engage in rigorous economic analysis in order to justify the proposed acquisition of debt. S44(1) states "Any Government in the Federation or its agencies and corporations desirous of borrowing shall, specify the purpose for which the borrowing is intended and present a cost-benefit analysis, detailing the economic and social benefits of the purpose to which the intended borrowing is to be applied".

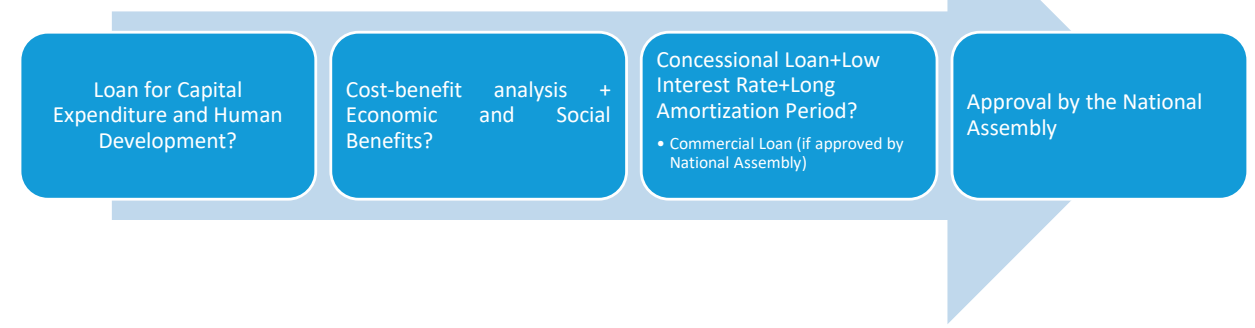

Figure 5: Debt Acquisition Process under the Fiscal Responsibility Act 2007

\section{Debt Limits}

S42(1) empowers the President, as advised by the Minister responsible for Finance, and as approved by the National Assembly to set limits of consolidated debt for all tiers of Government: Federal, State and Local. This section stipulates that limits are consistent with the provisions of the Act generally, and with the medium-term fiscal framework. Per S12(1) of the FRA 2007, government expenditure in each financial year is capped at the level of its estimated revenue, plus a maximum deficit level of 3 per cent of GDP. To 
ensure that government borrowing is maintained within these limits, $\$ 42(3)$ requires that the Commission investigate compliance of government agencies, on a quarterly basis. S42(4) mandates the Commission to "publish, on a quarterly basis, a list of the Governments in the Federation that have exceeded the limits of consolidated debt, indicating the amount by which the limit was exceeded". Where the set limits of borrowing have been exceeded, $\$ 42(5)$ requires that the excess be reduced by a minimum of 25 per cent in the following quarter, and brought within stated limits in the course of three (3) subsequent quarters.

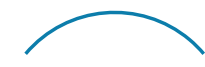

2a. President-set limits on all government borrowing (in a manner consistent with Medium Term Fiscal Framework).

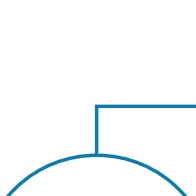

1. Advice from Minister of Finance

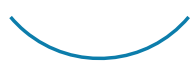

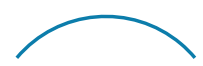

2b. National Assembly-approve government borrowing limits

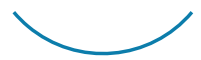

Figure 6: Institutional Matrix to Govern Borrowing Limits

The Minister responsible for Finance is empowered by $S 47(1)$ to provide guarantees on behalf of any Government in the Federation. S47(2) makes federal guarantees on debt acquired by other levels of Government contingent on a counter-guarantee in an amount equal to or higher than the guarantee obligation, if there are no obligations outstanding from the requester to the guarantor and its controlled corporations. Additionally, S47(2)(a) limits the recipients of guarantees to State and Local Governments,

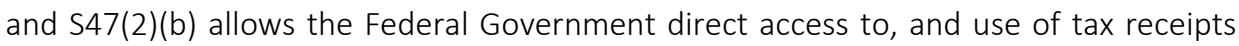
and statutory transfers of the recipient.

Importantly, S47(3) prohibits the acquisition of external or foreign currency denominated debt by State or Local Governments, or Federal Agencies, without a federal guarantee. Even so, the extent of guarantees provided by the Federal Government are subject to the limits on borrowing as set by the President. S47(4) renders unlawful guarantees by the Federal Government which exceed debt limits: "Any guarantee provided in excess of the debts limits set pursuant to section 44(1) of this Act shall be an offence". However, the Act does not specify the penalties for the offence, nor does it stipulate processes or institutions responsible for the enforcement of this provision. It seems that the Act serves as a tool of risk management, and as a deterrent, in order to manage the overall debt profile of the government and maintain public debt at sustainable levels. 
While the definition and level of sustainability are not prescribed, the National Assembly and Minister responsible for Finance are placed as the institution and official responsible for debt sustainability: S41(1)(c) states that "Government shall ensure that the level of public debt as a proportion of national income is held at a sustainable level as prescribed by the National Assembly from time to time on the advice of the Minister".

\section{Enforcement of Debt Management Rules}

a) Debt Acquisition and Use:

i. The provisions of S41 (purpose and procedure for government borrowing) create binding obligations on the Government, as seen in S41(3) which states "Noncompliance with the provisions of this section shall make the action taken an offence".

ii. S45(1) requires that Banks and Financial Institutions demand and obtain proof of compliance with the provisions of the Act concerning government borrowing, prior to the provision of debt finance to government. Failure to do so is created

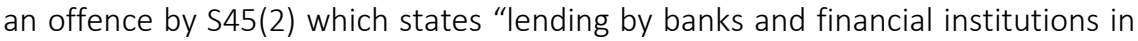
contravention of this Part shall be unlawful".

b) Debt Management:

i. S42(6)(a) stipulates that those arms or tiers of Government which do not comply with the stipulations which govern the limits of borrowing (S42(1)), are precluded from further borrowing, whether from internal or external sources, unless such borrowing is for the refinancing of existing debt.

ii. Also, S42(6)(b) states that violators of $\mathbf{S 4 2 ( 1 )}$ are required to "bring the debt within the established limit by restricting funding commitments accordingly".

iii. Where a tier or arm of Government fails to reduce the excess in borrowing limits within the time-period stipulated in S42(5), i.e., 3 quarters, S42(7) stipulates that the offending arm of Government is prohibited from receiving grants from any Government in the Federation.

c) Debt Repayment:

i. S43(1) stipulates that the burden of loan repayments will be borne by the tier of Government that obtained the loan: "Servicing of external debts shall be the direct responsibility of the Government that incurred the debt". Also, S43(2) states that the cost of servicing loans obtained by other tiers or arms of Government which are guaranteed by the Federal Government, are to be taken at source from the federation account.

ii. $S 47(2)(b)$ states that "the counter-guarantee required by the Federal Government from State or Local Government or by State from Local Government, may consist in the appropriation of tax revenue directly collected and resulting from statutory transfers and the guarantor shall be authorised to retain such revenue and use the respective amount to repay overdue debts". 


\subsubsection{Institutional Supervision of Fiscal Rules}

The first part of the Act deals with the establishment of the Fiscal Responsibility Commission: S1(1) of the FRA 2007 creates the Fiscal Responsibility Commission, which is designed to operate as a hybrid think-tank, economic watchdog, investigator and rulemaking institution. S3 of the Act states the responsibilities of the Commission;

3.-(1) The Commission shall:

(a) monitor and enforce the provisions of this Act and by so doing, promote the economic objectives contained in section 16 of the Constitution;

(b) disseminate such standard practices including international good practice that will result in greater efficiency in the allocation and management of public expenditure, revenue collection, debt control and transparency in fiscal matters;

(c) undertake fiscal and financial studies, analysis and diagnosis and disseminate the result to the general public;

(d) make rules for carrying out its, functions under this Act; and

(e) perform any other function consistent with the promotion of the objectives of this Act.

The independence of the Commission is explicitly stated in S3(2) of the Act. The composition of the governing board is prescribed in S5(1) which provides for broad representation of interest groups, including the Private Sector, Civil Society, Labour, the Federal Ministry of Finance, and Representatives of Geopolitical Zones. S10 implies that the Commission should operate as a Federal Agency supervised by the National Assembly: "The Commission shall prepare and submit to the National Assembly not later than 30th June in each financial year; a report of its activities including all cases of contravention investigated during the preceding financial year, and shall include in the report a copy of its audited accounts for the preceding financial year".

The work of the Fiscal Responsibility Commission in supervising the debt management provisions of the Fiscal Responsibility Act was to be complemented by the Debt Management Office (DMO). Legal underpinning for the DMO is the Debt Management Establishment Act of the National Assembly 2003. This Act amalgamated 7 government departments and agencies which managed external debt in Nigeria (Okonjo-Iweala, 2012).

S6 of the DMO Act empowers the DMO to discharge the technical functions of debt management within the Nigerian Government, including advising the Government on amounts to be borrowed, as well as the terms on which loans are to be obtained. The DMO is also mandated to supervise the issue of guarantees by the Federal Government, and is responsible for the execution of loan repayments on behalf of Governments in Nigeria. SS 21 and 22 of the DMO Act emphasize the function of the National Assembly in approving external loans, and prohibit the Minister responsible for Finance, and Federal Government Agencies from providing guarantees for external loans without the necessary approval of the National Assembly. The functions of the DMO, for the purpose of debt management (as stated in the DMO Act) are presented in the table below. 
The Fiscal Responsibility Act 2007 and the Debt Management Office Act 2003 are emphatic and deliberate in the restriction of the powers and abilities of the Nigerian Government, at all levels, to obtain debt finance. The Acts establish independent institutions, within government, to supervise, monitor and enforce legal stipulations which govern public debt management. Importantly, the Acts require that the government undertake technical, economic and social analyses, and present justifications for the acquisition of debt. These Acts detail the conditions, processes and circumstances which the government must follow, even as it disperses the decision making across different arms and tiers of government, in order to ensure that the acquisition, use and management of debt finance are prosecuted for the benefit of Nigerians; the National Assembly, as the arm of government which represents the Nigerian population, is designated as the final approval point for the acquisition of debt finance. In this way, the decision to acquire debt is decided by the Nigerian people. The Minister responsible for Finance is advised by the Budget Office and the Debt Management Office on the economic factors to consider in seeking debt finance. The President sets the limits for debt in a manner consistent with the medium-term fiscal framework, as approved by the National Assembly. All of these processes are governed by law, to ensure predictability, accountability and transparency in the acquisition, use and management of debt finance. The effectiveness of these Acts in regulating government behaviour are evaluated in Chapter 4.

Table 10: DMO Act- Functions of DMO for Debt Management

\begin{tabular}{|c|c|c|}
\hline Function & DMO Act S6 & DMO Act Other Sections \\
\hline $\begin{array}{l}\text { Debt } \\
\text { Acquisition }\end{array}$ & $\begin{array}{l}\text { (h) advise the Minister on the terms and } \\
\text { conditions on which movies, whether in the } \\
\text { currency of Nigeria or in any other currency, are } \\
\text { to be borrowed; } \\
\text { (i) submit to the Federal Government, for } \\
\text { consideration in the annual budget, a forecast } \\
\text { of borrowing capacity in local and foreign } \\
\text { currencies; }\end{array}$ & $\begin{array}{l}\text { 19.-(1) The Office shall annually advise the } \\
\text { Federal Government on the financing gap } \\
\text { for the succeeding financial year and the } \\
\text { amounts to be borrowed for bridging the } \\
\text { gap both internally and externally. } \\
\text { (2) Any advice issued by the Office under } \\
\text { subsection (1) of this section shall, among } \\
\text { other things, form the basis of the national } \\
\text { borrowing programme for the succeeding } \\
\text { financial year as may be approved by the } \\
\text { National Assembly. } \\
\text { (3) The Office shall participate in the } \\
\text { negotiation and acquisition of such loans } \\
\text { and credit referred to in Subsection (I) of } \\
\text { this Section. }\end{array}$ \\
\hline
\end{tabular}

Debt (b) prepare and submit to Federal Government a

Repayment forecast of loan service obligations for each financial year;

(d) verify and service external debts guaranteed or directly taken by the Federal Government;

(e) on agency basis, service external debts taken by State Governments and any of their agencies: where such debts are guaranteed by the Federal Government; 


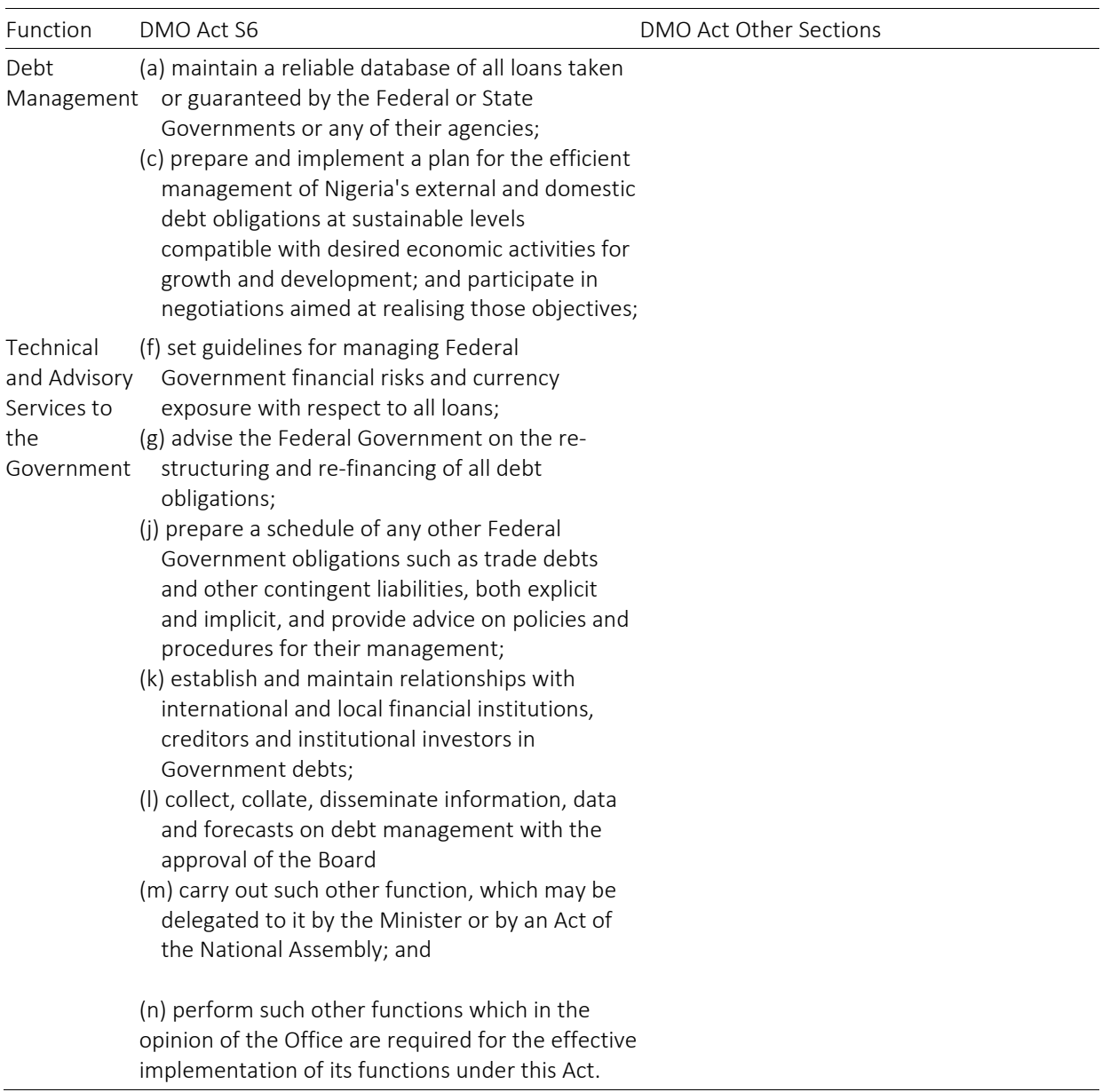

\subsection{Rwanda Poverty Reduction Strategy Paper}

The Government of Rwanda attributed progress recorded after the war and genocide to radical reforms (Ministry of Finance and Economic Planning, 2002). Thus, the Rwanda PRSP of 2002 was premised on the necessity of a coherent strategy for sustainable development and poverty reduction, which would avoid the economic stagnation the country had endured in its recent past (ibid). In this way, the PRSP can be considered as an expansive agenda of reforms, and an implementation approach for the country.

The Rwanda PRSP was a 10year development strategy intended to guarantee poverty reduction and economic growth. The Ministry of Finance and Economic Planning (MINEFCON), through the National Poverty Reduction Programme prepared the PRSP between 2000 and 2002. The development strategy presented by the Government was also a system for mobilization of Communities, the Private Sector, Civil Society and 
External Donors towards rebuilding the country. Through a national consultative process, the Government asserted that the priorities adopted addressed the needs of the poor, which would be tackled through actions guided by technical analysis (Ministry of Finance and Economic Planning, 2002). 6 areas were identified for priority interventions:

- Rural development and agricultural transformation

- Human development

- Economic infrastructure

- Governance

- Private sector development

- Institutional capacity-building

\subsubsection{Reform Agenda and Implementation}

The Government of Rwanda attributed poverty to two main factors, firstly, the failure to increase productivity as the population grew. The government refers to the "massive terms of trade shock" caused by the crash of the price of coffee on the international market in the 1980s (Ministry of Finance and Economic Planning, 2002, p. 6). The fallout was microeconomic problems which included: low agricultural productivity, low human resource development, limited opportunities for employment with an oversupply of unskilled workers, high population density and growth. Also, the country's landlocked position created high transport costs, even as the country suffered from environment degradation, chronic decline in soil fertility, poor water management, and deforestation (ibid).

Secondly, the war and genocide of 1994 "left a horrific legacy", and further impoverished the country (Ministry of Finance and Economic Planning, 2002, p. 6). It was estimated that up to 1 million people were killed, and 3 million fled to neighbouring countries. Infrastructure across the country was destroyed, and social links in rural and urban areas were damaged, which impeded internal commerce. Social problems abounded: 107,000 people in prison awaited trial for crimes related to genocide. These people created a significant economic burden on the state, as well as the women and children who provided their upkeep. Also, health problems were rife, including the prevalence of HIV due to the combination of large-scale population movements, and the use of rape as a weapon (ibid).

The Government embraced the challenge of rebuilding the country, and chose to revive and rely upon traditional social organisations, including:

- Umuganda: the tradition of work on public projects

- Ubudehe: the tradition of mutual assistance

- Gacaca: communal resolution of disputes

- Umusanzu: support for the needy and contribution to the achievement of a common goal 
Furthermore, linguistic homogeneity and high population density were also identified by the government as positive features to be utilized in the implementation of the national development strategy.

The Post-Genocide Government put forward its achievements, including stability, security, and a major programme of liberalisation, through which the country had recorded significant growth. Decentralization of governance and popular participation had been fostered by the establishment of political and administrative structures. These successes notwithstanding, the government highlighted challenges in the areas of shelter, demobilization, the legal system and restructuring of political institutions. To tackle these challenges, it was imperative for the Government to provide infrastructure and other basic services to support sustained economic growth. Indeed, the Government assumed primary responsibility for economic improvement: "without energetic public action, growth would be likely to falter, making poverty reduction impossible. Energetic public action to accelerate economic growth is therefore central to the PRSP" (Ministry of Finance and Economic Planning, 2002, p. 8).

The PRSP was coordinated by the National Poverty Reduction Programme, domiciled in the Ministry of Finance and Economic Planning, and implemented through the actions of Government and other parties. Actions undertaken under the PRSP were placed in the larger context of Rwanda's specific goal to become a middle-income country by 2020. In the area of public debt, the objective of the government was to maintain debt at sustainable levels, measured by NPV of debts-to-exports ratio of 150 per cent.

The country's overall long-term objectives were given in the PRSP (Ministry of Finance and Economic Planning, 2002) as:

1. Good political and economic governance

2. Rural economic transformation

3. Development of services and manufacturing

4. Human resource development

5. Development and promotion of the private sector

6. Regional and international economic integration and;

7. Poverty reduction

The preparation of the PRSP was central to the process of achieving debt relief. Government action to achieve the goals of the PRSP was directed toward 6 areas:

1. Institutional and legal changes

2. Resolution of regional conflict

3. Prioritization of public Expenditure in a coherent programme, in keeping with the Medium-Term Expenditure Framework

4. Development of sector strategies to define sector action plans

5. Development of decentralized and participatory structures and capacities of province, district and cellule level 
6. Establishment of principles, indicators and institutional mechanisms for development monitoring

A 2005 review of progress towards achieving the goals of the PRSP showed that the country's external debt profile remained high: its total obligations were projected to increase from US\$1.336billion in 2001 to US\$1.485billion in 2003 (International Monetary Fund, 2005). The objective of achieving debt sustainability, particularly NPV of debts-to-exports ratio of 150 per cent had not been achieved. Rather, in 2003, this stood at 299.9 per cent. Nonetheless, the IMF noted that debt relief which should have been granted at the HIPC expected completion point (2004), would have released funds to kick-start new productive investments in the economy. Notwithstanding the country's inability to reach the HIPC completion point, IFIs provided debt relief to the value of US\$22.93 million in 2003 (International Monetary Fund, 2005). Note that the HIPC Completion was determined by successful implementation of reforms by borrower countries (See 3.1.1). The 2005 report notes that the country had awaited US\$452million in relief since 1999. This position is corroborated by a 2001 report of the African Development Bank which states that Rwanda qualified for debt relief to the value of US\$452million at the end of 1999 (African Development Bank, 2001). This report also refers to the HIPC decision point of 2000, i.e., the point at which IFIs decided to provide debt relief to Rwanda. Also, the report speaks of the expected completion point, i.e., 2003, at which the country was expected to have implemented the PRSP for one year, maintained a balanced macroeconomic environment support by an IMF loan facility, economic reforms, including privatisation of state-owned firms, and improvements in social development (ibid).

In April 2005, upon reaching the HIPC completion point, the IMF and World Bank cancelled Rwanda's external debt to the value of US\$1.4billion. Pedro Alba, then World Bank Country Director for Rwanda stated that the completion point reflected "major and sustained efforts" the country had made towards implementation of reforms and the delivery of social services. Similarly, Kristina Kostial, then IMF Mission Chief in Rwanda noted that the country had largely achieved macroeconomic stability, and established a good track record of policy implementation in 2004 (News 24, 2005). Several months later, in December 2005, the IMF announced debt relief under the MDRI for Rwanda (along with 19 other countries), i.e., a 100 per cent cancellation of the balance of Rwanda's external debt, which was valued at US\$76million. This was provided to support the country towards the achievement of the MDGs. The country qualified to benefit from the HIPC as a result of its "overall satisfactory recent macroeconomic performance, progress in poverty reduction, and improvements in public expenditure management" (International Monetary Fund, 2005). Also, the IMF noted that the Organic Budget Law had been submitted to Parliament. The 2006 PRSP progress report notes that the country reached the HIPC completion point in 2005, and debt relief was expected to allow Rwanda save resources that would have been spent on debt service, 
estimated at US\$48million annually for a period of 10years (International Monetary Fund, 2006). Following debt relief, the country reached a sustainable debt position where the NPV of debt-to-exports ratio was recorded at less than 60 per cent (International Monetary Fund, 2008).

\subsubsection{Budget Reform: The Organic Laws on State Finances and Property}

In 2006, the Organic Law on State Finances and Property No 37/2006 of 12/09/2006 was enacted. This instrument was referred to in the 2002 PRSP as the forthcoming Finance Law (Ministry of Finance and Economic Planning, 2002). In 78 Articles, this legislation combines procedural and quantitative rules to supervise government use and management of public resources. Article 3 states: "This Organic Law relates to the composition, preparation, adoption and implementation of the budget of central administration, local administrative entities and other public entities, which is the general budget of state finances". The Organic Law provides various government offices and institutions with powers and responsibilities to execute its provisions. Macroeconomic stability is stated as the objective of government in Article 4, which stipulates that "the preparation and implementation of central Government and Local Administrative Entities budgets shall be made with the aim of attaining macroeconomic stability, by respecting budgetary and economic policies that ensure a sustainable and stable national economic development". Accordingly, public debt management is governed in Chapter $\mathrm{V}$, Articles 54 to 65.

The Law was revised in 2013 as the Organic Law No 12/2013/OL of 12/09/2013 on State Finances and Property. The 2013 Law is applicable to all levels of government per Article 2: "This Organic Law shall relate to public financial management of Central Government, Local Administration, Public Institutions and Parastatal Organizations". This implies the removal of the autonomy of decentralised authorities to prepare and adopt budgets; under Article 5 of the 2006 Law, local administrative authorities were authorised to implemented budgets to be approved by their respective councils. Furthermore, Article 5 of the 2013 Law creates an obligation on public institutions to comply with its general principles and provisions in the classification, preparation and approval of their budgets. Articles 50 to 61 of the 2013 Law govern public debt management, and are presented below, alongside the relevant provisions of the 2006 Law.

\section{Debt Acquisition and Use}

The Law states clearly the purposes for which the Government of Rwanda may borrow, i.e., economic stability and improvement. These purposes are stated in the table below: 
Table 11: $\quad$ Purposes for which the Government of Rwanda may borrow under the Organic Budget Laws

\begin{tabular}{|c|c|}
\hline 2013 Law: Article 51 & 2006 Law: Article 57 \\
\hline $\begin{array}{l}51 \text { On the basis of a funding proposal prepared and } \\
\text { presented by the Minister to the Chamber of Deputies } \\
\text { for approval, the Government may borrow money: } \\
\text { 1. to finance annual budget deficits; } \\
\text { 2. to refinance maturing debt or a loan paid before the } \\
\text { redemption date; } \\
\text { 3. to boost foreign currency reserves; } \\
\text { 4. to maintain credit balances on a bank account of the } \\
\text { consolidated Fund; } \\
\text { 5. to regulate monetary conditions should the necessity } \\
\text { arise; } \\
\text { 6. for any other purpose necessary for sound fiscal policy } \\
\text { and effective debt management. } \\
\text { The Minister shall have the powers to select, after } \\
\text { consultations with the National Bank of Rwanda, the } \\
\text { form, terms and conditions of borrowing, with the aim of } \\
\text { maintaining and improving national sovereign debt } \\
\text { ratings. }\end{array}$ & $\begin{array}{l}\text { 57 Upon proposal by the Minister, the Government } \\
\text { may borrow loans: } \\
\text { 1. to finances budget deficits; } \\
\text { 2. to repay the maturing debt or a loan prior to its } \\
\text { redemption date; } \\
\text { 3. for any other purpose necessary for sound fiscal } \\
\text { policy and effective debt management. }\end{array}$ \\
\hline
\end{tabular}

The 2013 Law expands the purposes for which the government may borrow from 3 to 6 , and directs the Minister responsible for Finance to consult with the National Bank on the nature and terms of loans to be obtained by the Government.

1.1. Authority to borrow is vested in the Minister responsible for Finance, with other levels of Government requiring the approval of the Minister prior to the acquisition of debt. While the 2006 law allowed Local Administrative Entities to obtain loans if these complied with relevant laws, the 2013 Law constrains the powers of these Entities to acquire debt, and introduces the approval of the Minister as a condition for borrowing. Also, the Minister is empowered to set a limit on amounts to be borrowed.

Whereas the 2006 Law stipulated that approval of Parliament is required to obtain external loans, the 2013 law does not expressly refer to conditions or approvals necessary to obtain foreign debt. The table below presents the provisions which state the authority of government agencies to acquire debt. 
Table 12: Authority to Borrow under the Organic Budget Laws

\begin{tabular}{ll}
\hline 2013 Law: Article 50 & 2006: Article 54 \\
\hline $\begin{array}{l}50 \text { The Minister shall be the sole person with the } \\
\text { authority to borrow or to permit borrowing for }\end{array}$ & $\begin{array}{l}54 \text { In accordance with the decisions taken by Cabinet, } \\
\text { the Minister shall be the sole authority to borrow or to }\end{array}$ \\
$\begin{array}{l}\text { purpose of financing the Central Government } \\
\text { budget deficit or to raise loans for other public }\end{array}$ & $\begin{array}{l}\text { permit borrowing public money from any legal entity or } \\
\text { from an individual for financing the central Government } \\
\text { entities. }\end{array}$ \\
budget deficit, or, to raise loans, for other public bodies.
\end{tabular}

The Minister shall also be the sole authority to give and approve guarantees and security for the loans granted to public institutions by financial institutions.

For decentralized entities, the Council of each entity may borrow loans only for development projects upon authorization of the Minister. However, the Minister shall, by use of instructions, determine the maximum amount that the Council may borrow without prior authorization from the Minister.

The members of organs of decentralized entities shall not have powers to give guarantees but may pledge securities for a debt. An Order of the Minister shall determine the procedures for giving and approving guarantees and pledging securities by decentralised entities.

Public institutions may borrow, but with authorization of the Minister.
The Minister shall also be the sole authority to give or approve securities for the borrowing, such as public enterprise and financial institutions. The powers may be delegated to other public officers.

In local administrative entities, the local council of each entity may borrow loans for development projects only in accordance with the law establishing the source of finances and property of Districts and the City of Kigali and their use.

As for loans from external sources, the approval shall be granted by Parliament.

Public enterprises may borrow, but with the approval of the Minister.

Autonomous, public entities, constitutional public bodies and extra budgetary institutions shall not borrow loans.

\section{Debt Management}

Like its precursor, the 2006 Law, the 2013 Law provides measures for the management of public debt, including an obligation for the Government to maintain a debt profile database. All levels of Government are required to keep detailed records of debt obligations and repayments. The provisions which govern debt management are presented the table below:

Table 13: Debt Management under the Organic Budget Laws

\begin{tabular}{ll}
\hline 2013 Law: Article 56 & 2006 Law: Article 60 \\
\hline $\begin{array}{ll}56 \text { The Minister shall, in consultation with the National } 60 \text { The Minister shall, in consultation with the National } \\
\text { Bank of Rwanda, maintain a detailed record of all } \\
\text { public debt and Government securities or guarantees } \\
\begin{array}{l}\text { on third party debt, as well as the repayment plan } \\
\text { under that debt. }\end{array}\end{array}$ & $\begin{array}{l}\text { public debt and Government securities on third party } \\
\text { debt, as well as the schedule of payments obligated } \\
\text { under that debt. }\end{array}$ \\
$\begin{array}{ll}\text { The Minister shall also maintain a detailed record of } \\
\text { Government loans to public entities and repayment } \\
\text { plan of such loans. }\end{array}$ & $\begin{array}{l}\text { The Minister shall also maintain a detailed record of } \\
\text { Government loans to public enterprises, local } \\
\text { administrative entities and extra budgetary funds, as } \\
\text { well as the payment schedule to Government of such } \\
\text { lnterest and principal payments to the Government } \\
\text { shall be recorded in an appropriate register monitored } \\
\text { and recognized as State revenues. }\end{array}$ \\
\hline
\end{tabular}


2013 Law: Article 56

Public entities shall maintain detailed records and accounts of borrowing and debt servicing, as prescribed by the Minister's instructions, to enable disclosure of liabilities to the State and other parties.
2006 Law: Article 60

In the following budget year, interest and principal payments to the Government shall be recorded in an appropriate register and shall be monitored in the context of the annual budget revenues.

Local administrative entities, public enterprises and extra budgetary funds shall maintain detailed records and accounts of borrowing and debt servicing, as prescribed by the Minister's Instructions.

Additionally, the Government is required to develop and publish a debt management strategy which specifies limits on public borrowing, as well as the types of loans which may be obtained by Government. Thereafter, the National Bank is mandated to execute the assignments necessary to implement the strategy. The relevant provisions are outlined in the table below:

Table 14: Debt Management Strategy under the Organic Budget Laws

\begin{tabular}{|c|c|}
\hline 2013 Law: Article 57 & 2006 Law: Articles 61 and 62 \\
\hline $\begin{array}{l}57 \text { The Minister shall prepare and publish each year } \\
\text { the public debt management strategy. He shall enact } \\
\text { instructions on any borrowing and loans the } \\
\text { Government may from time to time guarantee. } \\
\text { In formulating debt management guidelines and } \\
\text { implementing the annual debt management strategy, } \\
\text { the Minister shall, each year, consult with the National } \\
\text { Bank of Rwanda, so as to avoid any possible conflicts } \\
\text { among the objectives of fiscal, debt management, } \\
\text { trade, monetary and exchange policies. } \\
\text { In accordance with written agreement with the } \\
\text { Minister, the National Bank of Rwanda shall provide all } \\
\text { the services required for the execution of decisions on } \\
\text { effective management of public debt. }\end{array}$ & $\begin{array}{l}\text { 61The Minister shall prepare and publish a public debt } \\
\text { management strategy each year. He/she shall publish } \\
\text { the terms and conditions of any borrowing, as well as } \\
\text { those of loans the Government may guarantee from } \\
\text { time to time. } \\
62 \text { In formulating debt management guidelines and } \\
\text { I implementing the annual debt management strategy, } \\
\text { the Minister shall, each year, consult with the National } \\
\text { Bank of Rwanda, so as to avoid any possible conflicts } \\
\text { between the objectives of fiscal policy, debt } \\
\text { management policy, trade policy and exchange rate } \\
\text { policy. } \\
\text { In accordance with written agreement with the } \\
\text { Minister, the National Bank of Rwanda shall provide all } \\
\text { the services required for the execution of decisions on } \\
\text { effective management of public debt. }\end{array}$ \\
\hline
\end{tabular}

\section{Debt Limits}

The 2013 law introduces a mechanism to set limits on public debt. This responsibility is assigned to the Chamber of Deputies (lower legislative house), which is mandated to set the limits for Government borrowing on an annual basis. This provision dilutes the power of the Central Government to borrow, and requires the Government to review limits on public debt annually.

Article 52 of the 2013 Law states:

"While voting the annual budget, basing on the recommendations of the Central Government, the Chamber of Deputies shall set the overall general limit of the 
source of new borrowing as well as the securities that may be given by Central Government. Debt of third parties to be taken over by the Central Government shall be included within this limit. Subject to the approval of the Chamber of Deputies, the Minister may recommend different limits on:

1. total domestic borrowing, including short term overdrafts;

2. total foreign borrowing".

Furthermore, Article 53 of the 2013 Law specifies the process for debt monitoring and repayment: "The Minister or the Chairperson of the Executive Committee of the decentralized entity shall be the sole authorities to ensure that all payments required to meet debt obligations emanating from loans approved by the Chamber of Deputies or Council of the decentralized entity are budgeted for and payments made to creditors according to the repayment provisions of the loan agreements".

Through these provisions, the Organic Budget Law supervises and regulates the Government in the acquisition, use and management of public debt. The Law places the Minister responsible for Finance, and to a lesser degree, the National Bank of Rwanda as the official and institution responsible for public debt. Their functions include technical and economic analyses, as well as monitoring and reporting of other arms and agencies of government. The 2013 Law introduces restrictions on the powers of decentralized authorities to assume debt obligations, even as it expands the reasons for which the central government may borrow. The effectiveness of the Organic Budget Law in supervising the functions of the government of Rwanda in the area of debt management are evaluated in Chapter 4.

\subsection{Reforms: Laws and Institutions for Debt Relief}

The mechanisms and processes for debt relief necessitated the implementation of reforms which altered the fundamental systems for public finance management in Nigeria and Rwanda. These reforms reflect the influence and dominance of IFIs in the international finance system. As seen through the case-studies of both countries, the PRSPS were the basis for wide-ranging reforms in borrower countries. While the World Bank and IMF are quick to emphasize the 'country-driven' nature of the reform process, a review of the Nigeria and Rwanda experiences reveal striking similarities in reform agenda and execution. Both countries state macroeconomic stability as the overarching objective of economic reforms (See 3.3. for Nigeria and 3.4. for Rwanda). This is reflective of the influence possessed and exerted by international finance institutions on borrower countries. During the SAPs of the 1980s, the IMF was criticized for its focus on short-term economic improvement, particularly with the balance of payments situa- 
tion of borrower countries. However, the PRSPs, while centred on economic indicators, speak to the political, institutional and social aspects of national development. In this regard, Harrison's assertion that the PRSP and HIPC are upgraded versions of SAPs seem justified (See 3.1.2).

Also, the governance agenda of IFls can be observed in the roles and functions assigned to government in the reform agenda. In both countries, government (in consultation with stakeholders) determined the goals of development, the metrics by which achievement would be measured, and the implementation. In this regard, the argument put forward by Chang is validated, i.e., that the state coordinates change, provides vision, manages conflict and builds institutions (Chang, 1999). Importantly, the institutions approach is central to the reform agenda in both Nigeria and Rwanda. Both PRSPS articulated the institutional and governmental structures to manage the reform process. The Ministries of Finance in the national governments were assigned functions of supervision, coordination and mobilization in the execution of the reform agenda (See 3.3.3 and 3.4.2).

Legal reforms, specifically legislations were introduced to ensure the achievement of macroeconomic stability. These legislations are similar to and replicate rules which exist in other political and economic systems, both western and emerging economies (See 3.2). Legal instruments to guide and regulate government management of state revenue and expenditure, i.e., budgetary legislation were enacted in both countries: the Fiscal Responsibility Act 2007 in Nigeria and the Organic Finance Laws (2006 and 2013) in Rwanda. The provisions of these laws are extensive, as they stipulate the roles, functions and operations of government and its institutions. The laws also serve as tools to guide the behaviour of government in the performance of its functions and obligations: processes, timelines and standards for economic management are prescribed.

For the purpose of debt management, the provisions of the laws clearly stipulate the importance of prudence. Mechanisms are established to ensure that the powers and authority to acquire debt are restricted to specific arms of government. In the case of external debt, the approval of national parliaments is required prior to the acquisition of debt obligations. Furthermore, the justifications and reasons for which debt can be acquired are provided: for example, in Nigeria, borrower governments are required to present undertakings which directly benefit the Nigerian population. In Rwanda, the Government is allowed to borrow for the purposes of economic improvement, as qualified under the Budget Laws.

Importantly, budgetary legislations demand that governments undertake economic and technical analyses to manage the economy. Both countries adopted the mediumterm expenditure framework, through which 3year forward planning is undertaken, as well as annual calculations/reviews of revenue and expenditure. Debt management is given as a central responsibility of Government, assigned to the Ministers of Finance. While the definitions of debt sustainability are subjective, the budgetary legislations in both countries speak to sustainability, which can be interpreted as an attempt to avoid 
situations of unmanageable debt, as experienced in the 1980s and 1990s. Also, these legislations empower government institutions to undertake supervisory functions to ensure compliance with legal obligations concerning debt management. There is a clear connection between budgetary reforms and debt relief; the PRSPs of Nigeria and Rwanda referred to the necessity of legal instruments to manage public finance, and direct government management of public finances. The table below presents the relief obtained and budget-related reforms undertaken by the Governments of Nigeria and Rwanda.

Table 15: Debt Relief and Legal Reforms

\begin{tabular}{|c|c|c|c|c|}
\hline Country & Creditor & Amount Cancelled & $\begin{array}{l}\text { Proportion of debt (cancelled) } \\
\text { owed to Creditor }\end{array}$ & Budgetary Reform \\
\hline Nigeria & Paris Club & US\$18billion & 60 per cent & $\begin{array}{l}\text { Fiscal } \\
\text { Responsibility Act }\end{array}$ \\
\hline Rwanda & $\begin{array}{l}\text { Multilateral } \\
\text { Institutions }\end{array}$ & US\$1.5billion & $\begin{array}{l}\text { - To sustainable level- as } \\
\text { agreed under Enhanced HIPC } \\
\text { - } 100 \text { per cent under MDRI }\end{array}$ & $\begin{array}{l}\text { Organic Budget } \\
\text { Laws }\end{array}$ \\
\hline
\end{tabular}

These reforms provide the opportunity to examine the relationship between laws and economic development, particularly the ways in which institutions interact with the processes and outcomes of economic development. The PRSPs and Public Finance Laws in Nigeria and Rwanda (Fiscal Responsibility Act 2007 and Organic Budget Laws of 2006 and 2013, respectively) serve as strategy and management systems, speak to specific goal of macroeconomic stability, and explicitly seek to supervise the behaviour and functions of government in the area of public finance management. As such, it is possible to evaluate whether, and to the extent that laws and institutions have served to regulate government behaviour. Furthermore, these reforms, as prescribed by IFIs are intended to create conducive policy environments in which economic development can be achieved. It follows that the effectiveness and adequacy of these reforms for the purpose of the management of the process of economic development can be examined.

\subsection{Summary}

The experiences of Nigeria and Rwanda in obtaining debt relief reveal the political economy of the international finance system. Both countries received relief following the implementation of policy and institutional reforms. It can be argued that the borrower countries are in a weaker bargaining position, and as such, are constrained to adopt reforms, whether these are prescribed or recommended by creditors. The superior power of creditors in setting standards and measurements of economic performance, as well as the extent of influence these have in the economic position of bor- 
rower countries is exemplified in the case of Rwanda: the country's NPV of debts-toexports ratio drastically reduced as a result of debt relief granted, not necessarily as an outcome of economic improvement (See 3.4.1).

Nonetheless, reforms undertaken towards the implementation of PRSPs delivered benefits including; the establishment of procedures and systems to manage economic development. Budgetary legislations require governments to engage in planning, evaluations, forecasting and justifications, especially as these concern public debt management. Also, legal instruments regulate government behaviour, and establish a framework for institutional supervision of government behaviour, compliance with the stipulations of legislation, and performance of government functions. These reforms undertaken for the purpose of macroeconomic stability were intended to foster transparency, predictability and accountability in government, a stable policy environment, and debt sustainability. The effectiveness of these policy and institutional reforms in regulating government behaviour, and the adequacy of the provisions of budgetary legislation for the management of public debt are examined in Chapter 4. 

Chapter

Evaluating the Effectiveness of Legal Reforms to Regulate Government Management of Public Debt and Foster Debt Sustainability 
PRSP-led reform programs led to the enactment of budgetary legislations in Nigeria and Rwanda. These legal instruments regulate government management of public debt, to prevent the build-up of unsustainable debt portfolios. Importantly, these instruments stipulate the purposes for, and mechanisms by which the governments of both countries may acquire debt finance.

This chapter addresses the third question of this thesis- To what extent, have legal reforms contributed to the achievement of the objectives of debt relief? To answer this question, this chapter evaluates the effectiveness of budgetary legislations as they supervise government management of public debt, as well as the extent to which legal frameworks have contributed to the sustainability of debt portfolios in Nigeria and Rwanda. These evaluations are undertaken through the examination of the provisions of budgetary legislations, on the basis of two questions; firstly, have budgetary legislations affected government behaviour, and how? Secondly, have changes in government behaviour led to sustainable debt portfolios?

The case-study of Nigeria and Rwanda presents three important lessons for the use of law as an instrument of economic development. Firstly, laws have improved institutional practices in the management of public debt in both Nigeria and Rwanda. The examination of budgetary legislations in both countries highlight the importance of proper conceptualization of legal instruments which enable improved economic outcomes.

Secondly, the interplay of law and institutions, as considered through the evaluation the effectiveness of budgetary legislation in Nigeria and Rwanda portrays the reality of political systems as strong determinants of the success of legal reforms.

Thirdly, the World Bank and IMF continue to influence the debt management systems, and economic development paths of borrower countries through reform programmes, as well as ownership of the tools, and frameworks by which sustainable debt, and economic development are measured. As a result, the World Bank/IMF agenda are reflected and replicated in the governance systems of Nigeria and Rwanda, which has led to stronger governments, as well as increased capacity of state institutions to monitor and manage public debt portfolios. 


\subsection{Legal Reforms, Public Debt Management and Debt Sustainability}

The precarious position of borrower countries in the mid to late 1990s led to a series of reform initiatives within IFIs, including the debt relief mechanisms of the World Bank and IMF (HIPC and MDRI). These reforms provided relief on existing debt, and integrated the principle of debt sustainability into the policy and operations of governments, to avoid a repeat of the debt build-up of the 1970s and 1980s, and to foster the responsible use of debt finance.

The late 1990s ushered in an emphatic drive towards global development, i.e., tangible and measurable improvements in economies, social standards of living, and institutions or governance arrangements. The international development agenda was expressed through the Millennium Development Goals (MDGs), a fifteen-year (2000-2015) international partnership of 189 signatory countries to achieve 8 goals (United Nations Millennium Project, 2006). The MDG partnership and agenda terminated in 2015, whereupon the Sustainable Development Goals (SDGs) were agreed upon by 193 countries, as part of the 2030 Agenda for Sustainable Development. The SDGs expand the areas of concern to 17 , with achievement to be measured against a list of indicators for each goal (United Nations, 2015).

Debt sustainability is embedded into the wider international development policy and practice as an indicator of SDG 17, which presents the institutional, partnership and financing framework to support the achievement of the Goals. This framework includes official development assistance, debt relief, trade, capacity building, data monitoring and accountability, and technology. Specifically, Goal 17 seeks to "assist developing countries in attaining long-term debt sustainability through coordinated policies aimed at fostering debt financing, debt relief and debt restructuring, as appropriate, and address the external debt of highly indebted poor countries to reduce debt distress" (United Nations, n.d.).

Chapter 3 of this thesis presents the ways by which debt sustainability was used as the threshold to calculate and determine the eligibility of borrower countries for debt relief at international level. International institutions, particularly the World Bank and IMF which own the benchmarks, frameworks, metrics and tools by which debt sustainability is analysed, continue to influence the debt management systems of borrower countries. These analyses enable the evaluation of present financial health, calculation of risk of debt distress, and development of risk mitigation strategies. Some of these tools used for analysis of debt sustainability are presented in the table below: 
Table 16: Tools for Debt Sustainability Analysis

\begin{tabular}{|c|c|c|c|}
\hline Tool & Function & Owner & Source \\
\hline $\begin{array}{l}\text { Debt Management and } \\
\text { Financial Analysis System }\end{array}$ & $\begin{array}{l}\text { Build Capacity for Government } \\
\text { Management of Debt }\end{array}$ & $\begin{array}{l}\text { United Nations } \\
\text { Conference on Trade } \\
\text { and Development }\end{array}$ & $\begin{array}{l}\text { United Nations } \\
\text { Conference on Trade and } \\
\text { Development } \\
\text { (United Nations } \\
\text { Conference on Trade and } \\
\text { Development, 2016) }\end{array}$ \\
\hline $\begin{array}{l}\text { Debt Management and } \\
\text { Performance Assessment }\end{array}$ & $\begin{array}{l}\text { Strengthen Capacity and } \\
\text { Institutions to Manage } \\
\text { Government Debt in an } \\
\text { Effective and Sustainable } \\
\text { Manner in the Medium to Long } \\
\text { Term }\end{array}$ & World Bank & $\begin{array}{l}\text { World Bank } \\
\text { (World Bank, 2015) }\end{array}$ \\
\hline $\begin{array}{l}\text { Debt Sustainability } \\
\text { Framework }\end{array}$ & $\begin{array}{l}\text { Mobilize Resources for } \\
\text { Borrower Countries and Reduce } \\
\text { the Incidence of Excessive Debt } \\
\text { Build-Up. }\end{array}$ & IMF/World Bank & $\begin{array}{l}\text { International Monetary } \\
\text { Fund and World Bank } \\
\text { (International Monetary } \\
\text { Fund, 2016) }\end{array}$ \\
\hline & $\begin{array}{l}\text { Classify country position vis a vis } \\
\text { risk of debt distress }\end{array}$ & & (World Bank, 2014) \\
\hline
\end{tabular}

The Debt Sustainability Framework (DSF) of the IMF has been adopted by Nigeria and Rwanda to monitor their debt portfolios and measure sustainability, as will be seen in the sections below. This Framework analyses both external and public sector debt, and compares debt burden indicators to indicative thresholds over a 20year period (International Monetary Fund, 2016). The analysis results in 1 of 4 possible ratings, as outlined in the table below:

Table 17: Ratings under the IMF Debt Sustainability Framework

\begin{tabular}{ll}
\hline Rating & Description \\
\hline Low Risk & Debt burden indicators are well below the ratings \\
Moderate Risk & $\begin{array}{l}\text { Debt burden indicators are below ratings, but are at risk of change from macroeconomic } \\
\text { pressures or external shocks }\end{array}$ \\
High Risk & $\begin{array}{l}\text { Country does not face immediate repayment difficulties, but baseline scenario and stress } \\
\text { tests indicate a protracted breach of debt or debt service thresholds } \\
\text { Debt Distress }\end{array}$ \\
\hline
\end{tabular}

Source: (International Monetary Fund, 2016)

Ighodaro Omoigui, a Strategy Officer in the Development Finance Vice-Presidency of the World Bank explains that Debt Sustainability Assessments (DSA) are used by the IMF and International Development Association to determine policies for borrower countries, and influence the final DSA ranking of a country (Omoigui, 2017). The DSF also evaluates the policies of countries, using the Country Policy and Institutional Assessment tool of the World Bank. The IMF asserts that those countries with strong policies 
on the CPIA index are less likely to accumulate debt (International Monetary Fund, 2016). The DSF policy assessment is presented in the table below:

Table 18: Debt Burden Thresholds under the DSF

\begin{tabular}{llllllll}
\hline & \multicolumn{2}{l}{ Present Value of debt in per cent of } & & \multicolumn{2}{l}{ Debt service in percent of } \\
\cline { 2 - 3 } & Exports & GDP & Revenue & & & Export & Revenue \\
\hline Weak Policy & 100 & 30 & 200 & & & 15 & 18 \\
Medium Policy & 150 & 40 & 250 & & 20 & 20 \\
Strong Policy & 200 & 50 & 300 & & 25 & 22 \\
\hline
\end{tabular}

Source: (International Monetary Fund, 2016)

The DSF and Debt Burden Policy Evaluation reveal that sustainability, from the perspective of the World Bank and the IMF, is examined by macroeconomic performance. At domestic level, the PRSP-led debt relief process introduced budgetary legislations, which explicitly require the Governments of Nigeria and Rwanda to integrate debt sustainability analyses into economic planning. These analyses are conducted at regular intervals, usually on an annual basis, by governments of both countries, and IFIs. The following sections discuss the current external debt situations, and evaluate the extent to which legal and institutional reforms have contributed to sustainable debt portfolios.

\subsection{Nigeria: The Fiscal Responsibility Act 2007 and Nigeria's External Debt Portfolio}

S41(c) of the Fiscal Responsibility Act 2007 requires the Nigerian Government to ensure that debt is held at sustainable levels as prescribed by the National Assembly, on the advice of the Minister responsible for Finance. In practice, the Debt Management Office (DMO), located in the Presidency, is the Government Agency which performs the function of debt management through its technical and economic analyses, debt monitoring, and advice to the Government. The DMO publishes the national 3year Debt Management Strategy, as well the Annual Debt Sustainability Analysis. In June 2016, the DMO published the Nigeria Debt Management Strategy (2016-2019), which was developed using the Debt Management Strategy Analytical Tool of the World Bank and the IMF (Debt Management Office, 2016). Similarly, the 2016 Annual Debt Sustainability Analysis was conducted using the World Bank/IMF Debt Sustainability Framework for Low Income Countries (DSF-LIC) Analytical Tool (Debt Management Office, 2016). The 2016 Debt Sustainability Analysis covers all public debt, i.e., debts of the Federal Government, State Governments (external and domestic), and the Federal Capital Territory (ibid).

The evaluation of the effectiveness of legislative and institutional reforms on government borrowing must be preceded by a presentation of the current debt position of 
Nigeria. The table and figure below outline the evolution of Nigeria's public debt between 2011 and 2015.

Table 19: Nigeria Public Debt: 2011-2015

\begin{tabular}{|c|c|c|c|c|c|}
\hline & 2011 & 2012 & 2013 & 2014 & 2015 \\
\hline \multicolumn{6}{|c|}{ External Debt Stock (Federal and State Governments) } \\
\hline USD Millions & $5,666.58$ & $6,527.07$ & $8,821.90$ & $9,711.45$ & $10,718.43$ \\
\hline$\%$ of total & $(11.47)$ & $(11.17)$ & $(13.69)$ & $(14.58)$ & $(16.75)$ \\
\hline$\%$ of GDP & 2.36 & 2.50 & 1.73 & 1.84 & 2.18 \\
\hline \multicolumn{6}{|c|}{ Domestic Debt Stock } \\
\hline USD Millions & $35,882.86$ & $41,969.16$ & $45,722.41$ & $47,047.77$ & $44,857.85$ \\
\hline$\%$ of total & $(72.61)$ & (71.79) & $(70.98)$ & $(70.63)$ & $(70.11)$ \\
\hline$\%$ of GDP & 14.94 & 16.10 & 8.98 & 8.93 & 9.13 \\
\hline \multicolumn{6}{|c|}{ States Domestic Debt Stock } \\
\hline USD Millions & $7,870.42$ & $9,961.16$ & $9,874.58$ & $9,852.25$ & $8,401.92$ \\
\hline$\%$ of total & $(15.93)$ & $(17.04)$ & (15.33) & (14.79) & (13.13) \\
\hline$\%$ of GDP & 3.28 & 3.82 & 1.94 & 1.87 & 1.71 \\
\hline \multicolumn{6}{|c|}{ Nigeria Total Debt Stock } \\
\hline USD Million & $49,419.86$ & $58,457.39$ & $64,418.89$ & $66,611.47$ & $63,978.20$ \\
\hline$\%$ of GDP & 20.58 & 22.43 & 12.65 & 12.65 & 13.02 \\
\hline
\end{tabular}

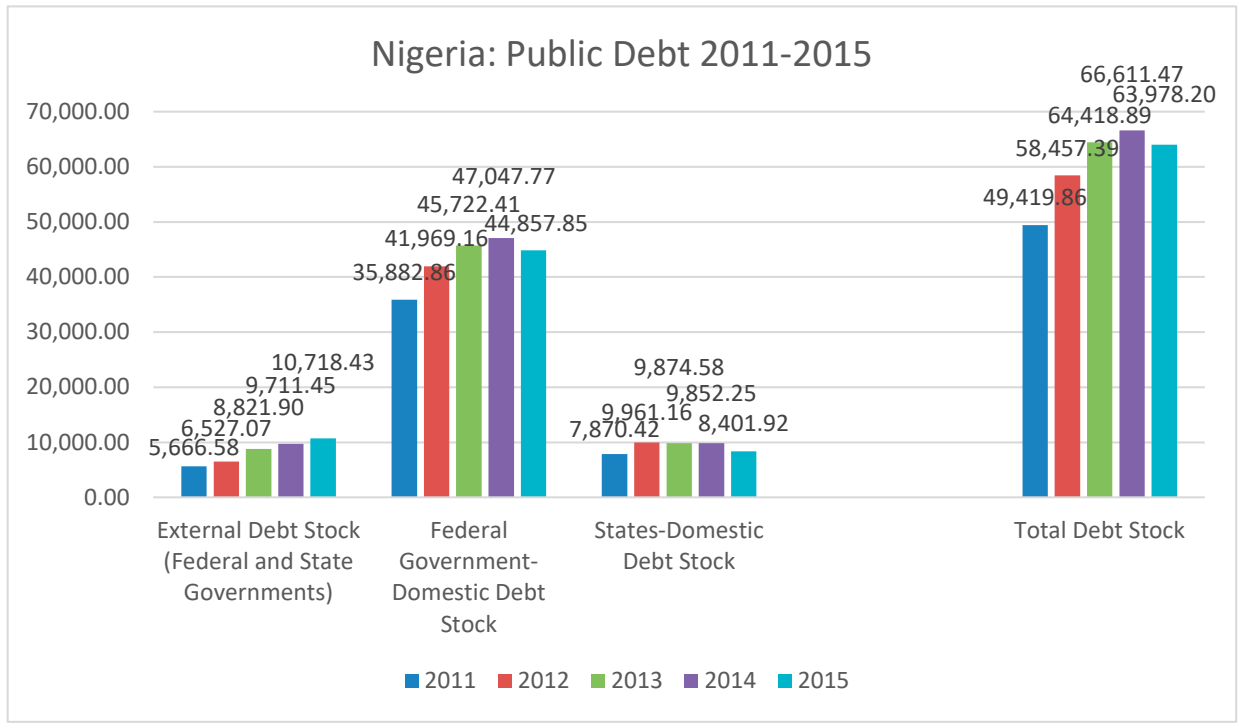

Figure 7: $\quad$ Nigeria: Public Debt 2011-2015 (US\$ millions)

At first glance, it can be argued that the FRA 2007 has influenced the debt management system of Nigeria: while the acquisition of external debt has generally been restrained, the Government has accumulated large domestic debts, with the Federal Government holding the greater share of liabilities. Currently, the national debt portfolio is divided 
between domestic and external debts on the ratio of 84:16 (Debt Management Office, 2016).

S41(1)(a) of the FRA directs the Government to seek concessional, rather than commercial external finance. Accordingly, the larger share of external debt finance has been acquired from concessional sources, as shown in the chart below.

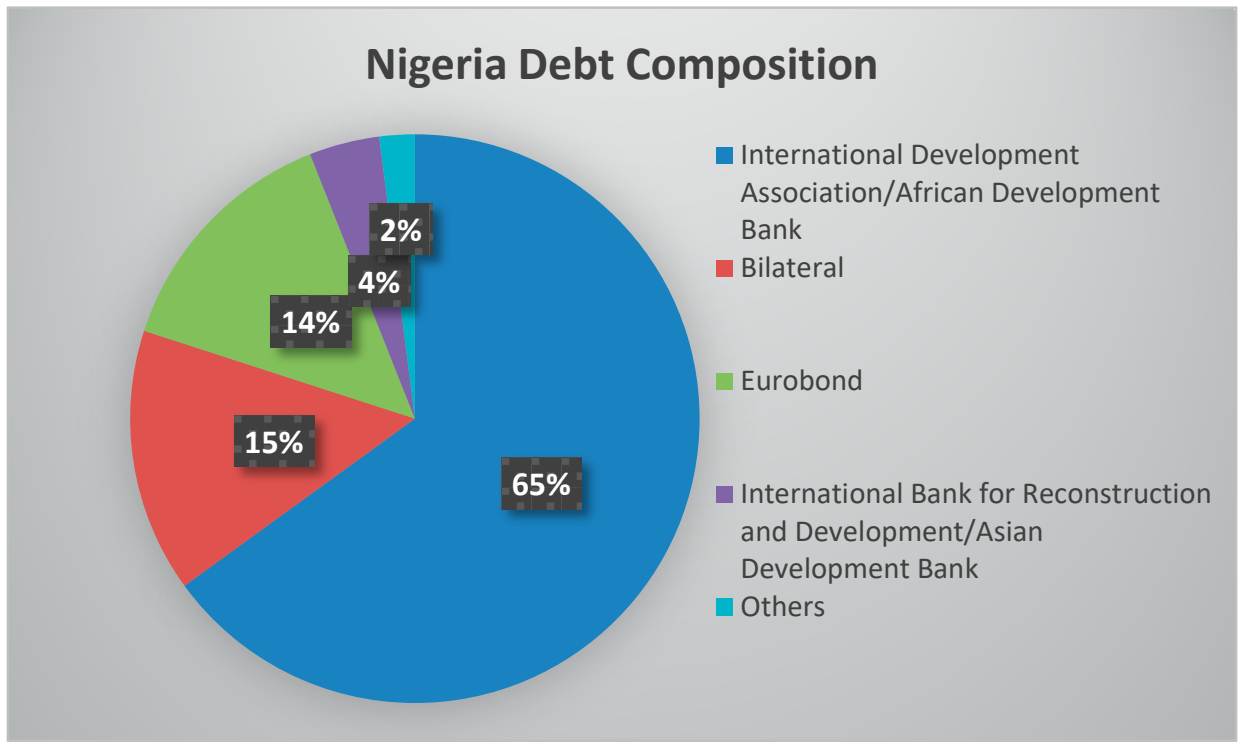

Figure 8: Nigeria: External Debt Composition in 2015

Furthermore, the preference for long-term debts as expressed in SS 41(1)(a) and 44(2)(b) of the FRA 2007 has guided government acquisition of debt, as the ratio of long-term to short-term debt stands at the ratio of 69:31 (Debt Management Office, 2016). The DMO does not distinguish between debts acquired by the Federal Government and State Governments in its calculation of external debt liabilities, and as such it is difficult to determine the proportion of debt owed by either level of government.

In March 2017, a former governor of the Central Bank of Nigeria, Professor Charles Soludo stated that the current administration (2015-2019) and previous administration (2011-2015) spent over 100per cent of its revenue on recurrent expenditure, and borrowed all its capital expenditure (Soludo, 2017). Professor Soludo also argued that Nigeria's economic problem is rooted in the ease of obtaining income from oil rents, and warned that imminent oil/commodity shocks will reveal, yet again, the importance of ending dependence on oil and commodities (ibid). In similar vein, the DMO noted in the 2016 Debt Management Strategy that the combination of a volatile macroeconomic environment and uncertain global economic outlook, caused by a structural collapse in the international price of crude oil, places the country under severe revenue pressure (Debt Management Office, 2016). In 2016, for the first time since the Paris Club debt 
relief process, the country's debt position dropped from low risk to medium risk of distress (Debt Management Office, 2016). Also, the country's debt portfolio remains vulnerable to shocks associated with revenue, exports and currency depreciation (ibid).

In view of the foregoing, it is necessary to examine the factors which allowed the accumulation of debt obligations by the Nigerian Government. The FRA 2007 is designed to regulate and direct government management of public finance, especially debt management. Thus, it can be argued that the country's debt portfolio can be interpreted in the context of this legal instrument, especially its conceptualisation and effectiveness. Accordingly, the next section investigates the interaction between the legal framework which supervises public debt management and government institutions in Nigeria.

\subsection{The Fiscal Responsibility Act 2007 and Public Debt Management}

The debt management provisions of the FRA 2007 can be organised into the following categories: debt acquisition and use, and debt management.

\subsubsection{Debt Acquisition and Use}

1. Economic Analyses: S44(1) of the FRA 2007 requires that Governments which seek to borrow must state the purpose of borrowing, and present a cost-benefit analysis which details the economic and social benefits of the debt acquired. Additionally, S45(1) requires Banks to seek and obtain confirmation of Part X of the Act (SS 44-47) prior to the provision of loans. According to BudgIT (2017), Ngozi Okonjo-Iweala, during her tenure as Minister of Finance (2003-2006, 2011-2015), "mandated all banks to seek approval before lending to State Governments. Some states were abusing their ability to borrow from banks". Currently, "the banks mostly ask that revenue allocations be domiciled in their banks for deduction at source" (BudgIT, 2017).

2. External Borrowing: the FRA 2007 requires Governments to obtain the approval of the National Assembly prior to the acquisition of external debt. The requirement of parliamentary approval, as well as the obligation to prepare technical analyses has created an effective preventative mechanism. The National Assembly has been effective in supervising the activities of the Executive arm of Government in this regard: in 2010, 5 years after debt relief was obtained from the Paris Club, and 3 years after the enactment of the FRA 2007, there was public outcry over the unsustainability of public debt, borrowing without due process, borrowing of non-concessional loans, and use of debt finance for purposes other than those for which they were obtained. This outcry led to the constitution of an ad-hoc committee of the House of Representatives (lower house), to investigate the borrowing practices of Govern- 
ments, and build the capacity of the National Assembly to effectively engage the Executive (Yelwa, 2010). Similarly, in 2016, the National Assembly referred to the procedural requirements of the FRA 2007, i.e., the requirement of economic analysis per S44(1), to withhold approval for the acquisition of external debt by the Federal Government (Tadaferua, 2016). Importantly, the FRA 2007 has changed the composition of Nigeria's debt stock. Prior to 2005 and debt relief, the bulk of Nigeria's debt was obtained from commercial creditors (See 2.2.1). However, by 2016, the larger share of external public debt (over 70per cent) had been obtained on concessional terms (see 4.2).

3. Borrowing by Sub-National Governments: under S47(3) of the FRA 2007, SubNational Governments are prohibited from the acquisition of foreign currency denominated debts without a Federal Government guarantee. BudgIT (2017) states that there are 4 levels of approval required for State Governments to acquire external debt: the proposed borrowing must be in accordance with the (1) multi-year debt plan of the Federal Executive Council and the (2) multi-year debt plan of the National Assembly. Also, external borrowing by State Governments must be absorbed into the (3) executive budget proposal for the fiscal year of the Federal Executive Council, as approved by (4) the National Assembly. To obtain a Federal Government Guarantee for external borrowing, State Governments follow a lengthy procedure, as outlined by BudgIT (2017):

"The State Government sends in their proposed external debt borrowing to the DMO/Ministry of Finance. After approval by the Federal Executive Council, the approved amount in line with the external debt cap is determined. Information is limited as to how the limit is reached. However, projected foreign exchange based revenue, existing liabilities and projected yield are considered. After the exit from the Paris Club of Creditors, Nigeria has turned to dipping into the domestic market. It is unclear how it is calculated but recent debt is tied to capital projects. The Federal Government after computing government projected deficit size for 3 years (as contained in the medium-term expenditure framework) decides based on the medium-term sector strategy whether domestic borrowing or external borrowing should be used. The final amount is subsequently decided based on series of complicated calculations, and the approval of the Federal Executive Council. Inputs and needs at Sub-National level are also considered and a final report is sent to the National Assembly for approval. After approval, the DMO draws out a plan to raise funds based on tranches in line with the supervising ministry, i.e. Ministry of Finance".

It can be argued that the FRA 2007 has limited the accumulation of external debt in Nigeria. Nonetheless, Nigeria's debt obligations, external and domestic, have steadily increased (See 4.2). External public debt stock was reduced from over US\$20billion to 
US\$3.5billion in 2006, after debt cancellation and the buy-back process with the Paris Club. In 2016, external debt liability had risen to US\$10billion, and is projected to rise further (Debt Management Office, 2016). Moreover, the domestic debt stock of the Government has accumulated rapidly, in part due to the ability of State Governments to obtain domestic loans without recourse to the Federal Government. It has been argued that "the high level of fiscal profligacy at sub-national level poses immense challenges for overall macroeconomic stability, debt management and public financial management" (Ushie, 2010, p. 4). The IMF corroborated this argument in its 2012 debt sustainability analysis for Nigeria, in which it highlighted the risks for debt management which emanate from the unavailability of data for loans procured by State Governments, as well as the ability of Sub-National Governments to acquire credit in the domestic market (International Monetary Fund, 2012).

Furthermore, the FRA 2007 does require the Government to account for the use of debt finance. According to BudgIT (2007), a civic society organisation which monitors the use of public funds in Nigeria, the technical analyses conducted by the DMO assess the ability of State Governments to meet obligations, but do not extend to supervision of debt finance once acquired. This approach can be described as reflective of the provisions of the Act which emphasize government computation and monitoring of obligations and liabilities, as well as enforcement of the prescribed procedure for external debt acquisition. Thus, it is difficult to hold the government accountable for the proper use of debt finance, i.e., for the purposes put forward in the borrowing request.

\subsubsection{Debt Management}

The FRA 2007 stipulates procedures and documentation systems for government management of public finance, and especially public debt. These can be categorised as rules which govern debt limits, debt monitoring and debt repayment.

1. Debt Limits: S42(1) requires the President, within 90 days of enactment of the FRA 2007, to set annual limits on the amount of debt that the Government can acquire. In 2017, 10 years after the enactment of the FRA 2007, BudgIT (2017) states that the practical debt ceiling is informed by S12(1) of the FRA 2007 which caps Government expenditure for a financial year at the total amount of revenue expected by government, plus a deficit 3per cent of GDP. However, S12(2) allows expenditure to exceed the stated caps if deemed necessary for national security or sovereignty by the President. Yelwa (2010), argues that the inability of the Nigerian Government to set limits on borrowing, especially on amounts which can be borrowed by Sub-National Governments is a principal cause of debt accumulation. In practice, it is the DMO that attempts to place limits on government borrowing. To illustrate, the Agency, in compliance with S6(i) of the DMO Act 2003, which mandates it to provide a forecast of borrowing capacity to the Federal Government, recommended a borrowing limit 
of US\$22billion from domestic and external sources in 2017. (Debt Management Office, 2016). While S19(2) of the DMO Act states that DMO calculations of borrowing needs should form the basis of the national borrowing plan, DMO recommendations are not necessarily binding on Federal and State Governments, or on Government Agencies. The DMO noted in its 2016-2019 Debt Management Strategy that State Governments calculate financing and borrowing needs based on their particular contexts (Debt Management Office, 2016). Also, State Governments have on occasion, procured loans in the domestic market without providing information to the Ministry of Finance (BudgIT, 2017).

2. Enforcement of Debt Limits: S42(3) of the FRA 2007 mandates the Fiscal Responsibility Commission to publish, on a quarterly basis, a list of Governments which have exceeded the consolidated debt limits. S42(5) requires debt to be brought within limits over the course of 1 year. However, these provisions cannot be enforced against Sub-National Governments and Agencies, as debt limits have not been set by the Federal Government. Similarly, S47(4), the provision which precludes the Federal Government from the provision of guarantees which exceed debt limits, cannot be enforced. Also, S42(6) which precludes governments from borrowing if their portfolios exceed limits cannot be enforced. Furthermore, the Fiscal Responsibility Commission has been scrapped, and its functions absorbed into the Revenue Mobilisation Allocation and Fiscal Commission.

3. Debt Monitoring: S6(a) of the DMO Act 2003 mandates and empowers the DMO to maintain a reliable database of all loans acquired by all Governments in the Federation. The Agency performs this function through its consolidated debt database, made public on its website (www.dmo.gov.ng), and updated on a quarterly basis.

4. Debt Repayment: the Federal Government enforces S43(2) of the FRA 2007 which authorises the deduction of debt service amounts, i.e., external debt owed by State Governments and guaranteed by the Federal Government, from revenue allocations. BudgIT (2017), states that applications (from State Governments to the Ministry of Finance) to acquire external debts are accompanied by an Irrevocable Standing Payment Order (ISPO), which allows outstanding funds, cost of debt and capital repayment on all external debt payments to be deducted from source. State allocations are generated from revenues which accrue from government receipts (sale of crude oil, tax, etc.), and disbursed by the Federal Government per an agreed formula (See 3.3.1). Where governments borrow in the domestic market and independently of the Federal Government, repayments are managed by the Banks. According to Patrick Okosodo, an officer with Diamond Bank Plc (Nigeria):

"Commercial banks handle diverse tax collections on behalf of State Governments, some of which include personal income tax, withholding tax (individual), road taxes, capital gain taxes etc. Based on the average balance in government accounts, banks usually advance loans to State Governments to finance capital 
projects and for their day to day expenses. Repayment of these loans are tied to the average minimum balances in government accounts, which can be structured for years until the principal loan sum and accrued interest have been fully liquidated". (Okosodo, 2017)

Okosodo (ibid) emphasises that loans are structured so that the minimum balance in the collections account is sufficient to service principal and interest due on a monthly basis. In this way, banks ensure repayment and avoid sub-prime loans to government.

High debt obligations necessarily yield high debt service payments. The figure below presents the cost of Nigeria's debt service between 2011 and 2015.

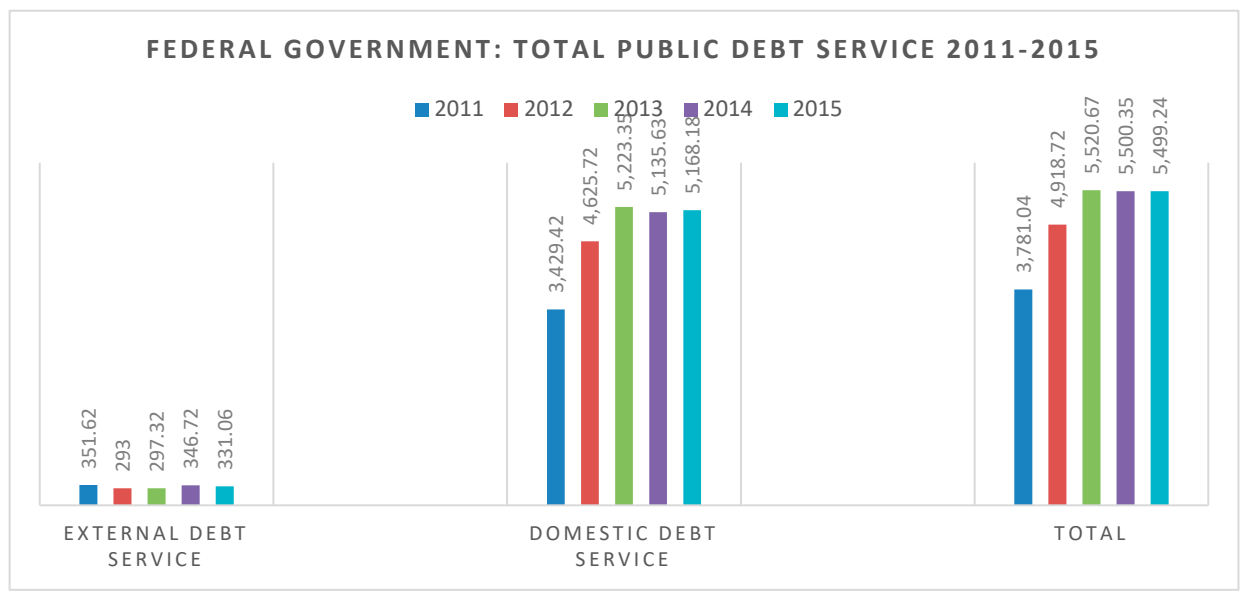

Figure 9: $\quad$ Federal Government: Total Public Debt Service 2011-2015 (US\$ millions)

(Debt Management Office, 2016)

Nigeria's debt obligations and debt service payments are expected to rise over the near, medium and long term. The DMO has recommended that the government acquire additional external, long term debt, and reduce the ratio of domestic to external debt to 60:40, from 84:16 (Debt Management Office, 2016). A decade after debt relief from the Paris Club, the current administration (2015-2019) sought the approval of the National Assembly to borrow US\$29billion and increase Nigeria's debt stock by 150per cent, and the external debt stock by 62 per cent over 2 years. These funds were to be designated for the prosecution of capital projects, "with special emphasis on infrastructure, agriculture, health, education, water supply, growth and employment generation, poverty reduction through social safety net programmes and governance and financial management reforms among others" (Nwachukwu, et al., 2016). The National Assembly rejected the request of the government on the basis that it was not supported by a borrowing plan (Tadaferua, 2016). Again in 2017, the Presidency submitted to the National Assembly a request for approval to obtain a US\$5billion loan to be used to up- 
grade transport infrastructure. This loan was to be obtained from the China-Africa Fund through the China EXIM Bank (Opejobi, 2017). This request was still under review as at June 2017.

\subsection{Evaluating the Fiscal Responsibility Act 2007}

The Fiscal Responsibility Act 2007 has introduced procedures which have streamlined the acquisition of external debt, even as they guide government management of finance, and public debt. The measures introduced ensure that the Ministry of Finance, through the Debt Management Office is the sole channel for the computation, acquisition and repayment of external public debt. Also, borrowing requests are approved by multiple authorities, which evaluate the request against the parameters provided by the Act, and instituted by the DMO. These parameters include the purpose of the loan, the justification of the loan, and the type of finance sought. Importantly, external debt acquisition is integrated into the wider economic planning/management framework, i.e., medium-term fiscal/expenditure frameworks and annual forecasts. This system has reduced the opportunity for, and incidence of external borrowing. Thus, the Act creates a framework which directs the Nigerian Government in economic planning and management. Ushie (2010) asserts that the FRA 2007 has introduced a planned approach to government spending which reduces exposure to exogenous factors. Also, she has argued that the rule-based method for revenue calculation, and the Excess Crude Account enabled the country weather the global economic crisis of 2010 (ibid).

The Act supports a Government Institution, i.e., the Debt Management Office in the performance of its functions. The Agency fulfils its functions, as prescribed by its enabling Act, as well as the FRA 2007, especially those of technical and economic analysis, as well as debt monitoring. Similarly, the National Assembly, which approves government borrowing from external sources, has relied upon the provisions of the FRA 2007 for the interpretation and discharge of its functions. Furthermore, the legal framework governs the relationships between institutions in the management of public finance, e.g., the Executive and the Legislature, Government Agencies and Government Ministries, and Federal and Sub-National Governments.

All these notwithstanding, the FRA 2007 has not effectively constrained government borrowing, or contributed to ensuring the sustainability of public debt. Several important realities are not addressed in or through the Act, especially as these concern the functions of government. These realities include: the political and administrative system of Nigeria, and the vulnerability of the Nigerian economy to external shocks. Additionally, government use of debt, particularly as it is deployed for developmental purposes, is not supervised by the Act. Furthermore, public debt management is made entirely the preserve of government, and does not incorporate other actors or institutions. 


\section{Political and Administrative System of Nigeria}

S41(1) of the FRA 2007 (procedure for acquisition of external debt) is binding on all levels of the Nigerian Government. However, other levels of Government, including State Governments and Public Agencies can acquire loans from the domestic market, without necessarily seeking the approval of the DMO or the Ministry of Finance. Thus, in effect, the provisions of the Act are enforceable against the Federal Government and its agencies, only. Ushie (2010) notes that 20 of Nigeria's 36 State Governments have adopted Fiscal Responsibility Laws. While state-level fiscal responsibility rules may serve to guide State Governments in their management of public finance, they do not end the disparate approach to overall government borrowing in Nigeria, and may not influence Governments to operate to common standards or objectives. In this regard, the usefulness of the FRA 2007 as a benchmark and guide for government borrowing is severely diluted. The result is a national debt stock which remains subject to the variant and fluctuating behaviour of different Governments.

To enable prudent debt management in the context of Nigeria's federal system, Yelwa (2010) outlines measures to improve fiscal discipline and compliance with the Act, e.g., the establishment of debt limits, suspension of allocations to states which do not comply with borrowing limits, denial of guarantees, technical assistance for State Government-owned FRAs, as well as prosecution for public officials who flout the provisions of the Act. These measures are dependent on political will, and would likely be subjected to legal challenges, as they affect the autonomy of State Governments within the federal system.

\section{Structura/ Change and Economic Development}

The Nigeria PRSP, and the Fiscal Responsibility Act 2017 were conceived and adopted as instruments of economic transformation. The PRSP was presented as a home-grown action plan to drive economic development through structural change and institutional reforms (See 3.3). However, 70 per cent of government revenue in 2017, three decades after SAPs of the 1980s, is based on receipts from the sale of crude oil (Debt Management Office, 2016). Recent events, including sabotage by militant groups in the oil producing Niger-Delta region have significantly reduced levels of oil production (Jannah, 2017). These occurrences reduce government revenue, and lead the government towards the acquisition of debt finance. Also, the Act has not contributed to significant improvements in accountability of public revenue, or curtailment of high recurrent expenditure (Ushie, 2010; See 4.2).

This situation exposes a subtle disparity between the PRSP, which focused on futuristic economic, institutional and social transformation, and the budgetary legislation, which was developed to manage present economic and political realities. From a legal perspective, it raises a question- to what extent, if any, can legal instruments incentivise and drive economic diversification? Also, how can Nigeria's budgetary legislation be 
made more responsive to the dynamisms of economic change? Certainly, in the case of Nigeria, the exploration of these questions will contribute to the refinement of the legal framework which governs public finance management, to foster beneficial structural economic changes.

\section{Debt for Development}

While the FRA 2007 controls external borrowing through a combination of quantitative and procedural rules, it does not directly address the use of debt finance in Nigeria. The provisions of the FRA 2007 reflect the World Bank/IMF concern with debt sustainability from a macroeconomic perspective, and as such prescribe economic analysis and procedural tools for debt management. However, the use of debt finance, particularly as deployed towards developmental purposes is not addressed. The Nigeria PRSP, and debt relief campaign was premised on the argument that debt servicing diverted government resources away from social development. It followed that debt relief would increase resources available for government to expend on the delivery of social services. However, borrowing patterns over the last decade have resulted in a significant proportion on national revenue being spent on debt service (See 4.2). Importantly, there is not yet established a mechanism to track government utilisation of debt finance. If the misuse of borrowed funds contributed to the build-up of debt portfolios in the 1970s and 1980s (See 2.2.2 and 2.4.2), then it is conceivable that legal instruments which stipulate justifications for government borrowing, can create mechanisms by which governments account for the utilisation of debt finance.

\section{Public Debt Management: A Need to Review the Functions of Government Institutions}

The Act does not create participatory roles and functions for other actors in the management of public debt. While Banks are required to ask Governments for evidence of

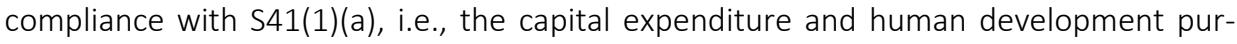
pose of borrowing, the Act does not detail how compliance should be ascertained, and to whom compliance should be communicated. The burden of investigating the compliance of Governments with the provisions which govern public borrowing is placed on a Government Agency, i.e., the Fiscal Responsibility Commission, which has been absorbed into the Revenue Mobilisation Allocation and Fiscal Commission (See 3.3.2). It is impossible to evaluate the effectiveness of these Agencies in performance of debt monitoring, as debt limits are yet to be set. It may be beneficial for the Government of Nigeria to investigate the means by which other actors, e.g., financial institutions and civil society organisations, can support the monitoring of debt finance as used by Governments.

10 years after the enactment of the FRA 2007, the Government is yet to set debt limits (BudgIT, 2017), which has allowed the accumulation of a large domestic debt stock. The Act places the greater share of debt management responsibility on the Executive Arm of Government, i.e., the President, Minister of Finance and the Debt Man- 
agement Office. However, the current state of Nigeria's debt stock demands a review of the legal framework. While there are consequences for Agencies and Governments which fail to comply with the provisions of the Act, there is no measure, whether punitive or incentive for the President to set debt limits. The Act seems to assume that the President will be disposed to, and capable of setting debt limits. However, this assumption has been disproved, as debt limits are yet to be established.

Interestingly, the FRA 2007 assigns the function of setting debt limits to a Person holding an office, not an institution. It can be argued that the political nature of this office creates difficulties for the performance of this function. Firstly, it is unlikely that other arms of Government, e.g., the National Assembly and the Judiciary will take legal action against the President on the matter of debt limits. The President is nominally the most powerful person in the Government. Secondly, it may be that the President may find it easier to allow, rather than prevent uninhibited borrowing by Governments within the Federation. Attempts by the President to set borrowing limits may be interpreted by other Governments as measures to constrain their power, and reduce their effectiveness. This interpretation can engineer animosity and altercations between Federal and State Governments. Thirdly, the President may not necessarily possess the capabilities for this function, i.e., the capacity to conduct independent economic and situational analyses.

Based on this situation, it would seem expedient that obligations, accompanied by measures to ensure compliance, are placed on institutions, not on persons within Government. Also, compliance should be supervised by another arm of Government imbued with the requisite powers and authority to enforce legal obligations. To illustrate, Section 4.3.1 above discusses the function of the National Assembly in public debt management, i.e., review of Government Borrowing requests against the benchmarks of the FRA 2007, and how this function of the Parliamentary Institution has curtailed government borrowing (Tadaferua, 2016).

\section{Possible Remedy: Centralisation of Government Borrowing}

The Federal Account Allocation Committee (FAAC) distributes revenue between Federal, State and Local Governments according to an agreed formula (See 3.3.1). In the same vein, borrowing of Federal and State Governments can be coordinated at the Federal level. A central body, such as the FAAC can adopt the overall borrowing limit recommended by the DMO, and allocate borrowing limits/levels between Sub-National Governments, depending on a number of considerations including, indebtedness, revenue generation, purpose of borrowing, etc. The DMO engages in the necessary economic and technical analyses for debt management, monitors the government debt portfolio, and recommends caps on government borrowing on an annual basis. Thus, the FAAC, or a similar body at Federal level, can develop a ratings or ranking system to determine the creditworthiness of Sub-National Governments. Importantly, domestic 
borrowing above set thresholds (amount and/or loan tenor) would be undertaken through central mechanisms, as done for external borrowing by the DMO.

While the centralisation of borrowing will create political contestations, the comparatively lower level of Nigeria's external debt portfolio illustrates the efficacy of legal and procedural constraints on Government borrowing (Tadaferua, 2016). Also, the centralisation of borrowing can reward good performers, and limit the liabilities created by poor management of debt portfolios by State Governments, as there would be ongoing scrutiny of debt management against the revenue obtainable by these Governments. Furthermore, the constraints created by the centralisation of borrowing may well incentivise Governments to improve their economic performance and debt portfolios, in order to access loans.

In effect, this would be a 'light-touch' approach to qualitative monitoring of the use of debt finance and management of debt portfolios by the Federal and State Governments. Legal underpinning for this approach can be obtained via an amendment of the FRA 2007. It may be argued that the Presidency is best suited to put forward the rationale for the amendment of this legal instrument by the National Assembly.

Note that the centralisation of borrowing is based on the premise that the bulk of revenue of the Nigerian Government is obtained from the FAAC distributions, which are financed largely by oil receipts. Should there be successful economic diversification in the future, it will be necessary to reform the centralised approach. In addition, increased revenue generation by individual State Governments will weaken the effectiveness of centralisation, as these Governments will have access to alternative sources of revenue, which would reduce their dependence of FAAC allocations.

\subsection{Rwanda: The Law on State Finances and Property 2013 and Rwanda's Debt Portfolio}

In 2016, the IMF Debt Sustainability Analysis of Rwanda ranked the country at low risk of debt distress. This ranking resulted from an evaluation of the country's policy environment and good economic performance (International Monetary Fund, 2016). In similar vein, the 2015 Debt Sustainability Analysis conducted by the Rwanda Ministry of Finance and Economic Planning concluded that country's debt levels were sustainable and well below the indicative thresholds for debt distress (Ministry of Finance and Economic Planning, 2015). The sustainable perception of Rwanda's public debt stock has led to a change in the types of finance obtained from IFIs, i.e., the country's favourable ranking has caused an increase in loans, and a decrease in grant finance (Ministry of Finance and Economic Planning, 2015). The proportion of loans in multilateral official development assistance to Rwanda increased from 20per cent between 2006 and 2013, to 45per cent in 2014 (Cassimon, et al., 2016). The HIPC and MDRI processes led to debt relief in 2005, which reduced Rwanda's debt portfolio to sustainable levels. In monetary 
terms, its external debt portfolio was reduced to less than US\$500million from US\$1.5billion (Murenzi, 2010). However, public debt levels began to rise as the country sought debt finance to drive the achievement of its developmental goals. In 2006, its total debt stock stood at US\$750 million, of which external debt accounted for US\$479million. In the same year, budgetary legislation was enacted to regulate government management of public debt. By 2015, total public debt had increased to US\$2.4billion, with external debt obligations at US\$1.8billion (Cassimon, et al., 2016). The sections below consider the effectiveness of the Law on State Finances and Property 2013 in the regulation of the acquisition and management of public debt, through a review of the provisions which govern debt acquisition and debt management.

\subsubsection{Debt Acquisition and Use}

1. Authority to Borrow: Article 50 of the Organic Budget Law 2013 vests authority to borrow, and authority to approve borrowing in the Minister responsible for Finance - whether loans for the Central Government deficit or loans for other Public Entities. Also, the Minister is the sole authority to give and approve guarantees and securities for loans obtained by Public Institutions from Financial Institutions. Article 50 goes further to explicitly prohibit government borrowing without the approval of the Minister: "Public institutions may borrow, but with authorization of the Minister".

Furthermore, Article 50 is specific as to the powers and authorities of different levels of Government as these pertain to public borrowing. For example, while Decentralised Authorities may pledge securities for a debt, they may not give guarantees. This provision centralises government borrowing in the office of the Minister responsible for Finance, which suggests that there is a coordinated and structured approach to government borrowing. This suggestion is validated by Gerard Gakunzi of the Debt Management Unit, a department supervised by the Office of the Chief Economist in the Ministry of Finance. Gakunzi (2017) also provides the multilevel process of approval and analysis required for the Government to seek and manage external debt, which is shown below:

a) Preparation of preliminary project proposals by the line ministries which will be submitted to the National Investment Planning Unit (NIPU) in the Ministry of Finance.

b) Review of the Financing Options by the Investment Committee

c) Review of the project proposal and preparation a draft concept paper by the External Finance Unit which will include loan terms and conditions that will be sent to the Debt Management Unit.

d) The Debt Management Unit shall undertake a Stress Test Analysis, on the basis of the information contained in the concept paper drafted by the External Finance Unit. 
e) The Debt Management Committee shall ensure that the total envelop of projects subject to external financing is in line with the existing Rwanda Debt Strategy and therefore advise the Executive Management.

f) The Executive Management on the basis of the guidance provided by the Debt Management Committee will review the loan and submit it to Minister's office for his approval.

g) Minister's Approval

h) The External Finance Unit starts negotiation with Creditors.

i) After the signature of any loan agreement between the Government of Rwanda and one of its Development Partners, the Ministry of Finance follows up the effectiveness of the signed Agreement through Ratification process.

j) When the loan is contracted, the agreement is sent to the Debt Management Unit to be recorded in the debt database.
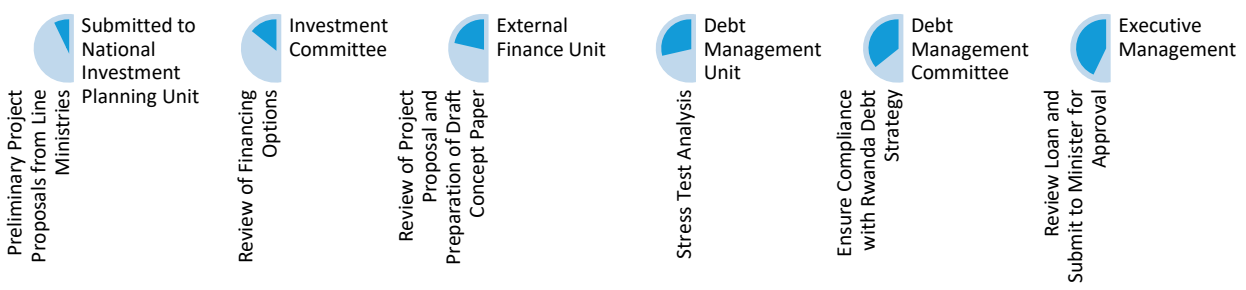

Figure 10: Rwanda External Debt Acquisition Process

From the foregoing, there are up to 6 levels of computation and review within the Central Government, prior to the approval of the Minister of Finance. These processes combine procedural rules with economic analyses, and integrate the use of benchmarks, e.g., the Rwanda Debt Strategy to ensure prudence in debt acquisition. Borrowing by State-Owned Enterprises, e.g, RwandAir, are reflected in the debt portfolio of the Central Government (International Monetary Fund, 2016).

2. Purpose of Borrowing: per Article 51 of the Law, the Government of Rwanda may borrow for up to 6 clearly stated objectives; to finance the annual budget deficit, to refinance maturing debt or a loan paid before redemption date, to boost foreign currency reserves, to maintain balances on a bank account of the consolidated fund, to regulate monetary conditions should the need arise, and for any other purpose necessary for sound fiscal policy and effective debt management. These conditions are necessarily macroeconomic in nature, and do not speak to a developmental purpose, as in the case of Nigeria. However, the wording of Article 51 seems to require the approval of the Parliament for all borrowing, on an annual basis: the Government may borrow money "on the basis of a funding proposal prepared and presented by the Minister to the Chamber of Deputies for approval". Thus, in addition to a single channel, i.e., the Minister of Finance for borrowing, there is an additional 
layer of approval, i.e., the Chamber of Deputies, for acquisition of all types of public debt. In this regard, the Executive and the Legislature are mandated to cooperate in a holistic manner to manage government debt. Additionally, per Article 51, the Minister is obligated to consult with the National Bank of Rwanda to determine the form and terms of borrowing. Both parties are obligated to work towards "improving national sovereign debt ratings".

The Law on State Finances and Property 2013 does not require disclosure of the use of debt finance, and the Government does not necessarily account for the particular use of its borrowing. Nonetheless, significant projects, e.g., the Kigali Convention Centre, as well as purchase of aircrafts for RwandAir feature prominently in its Debt Sustainability Analyses. However, it may be surmised that debt finance is integrated primarily into budgetary expenditure, which is supported by the legal framework. Indeed, the Law seems to anticipate that the bulk of borrowed finance will be used for general budgetary purposes. As such, the Minister of Finance, with the approval of the Chamber of Deputies is provided the freedom to coordinate government borrowing. In the 2016/17 fiscal year, 18.9per cent of the annual budget was sourced through external financing (Rwanda Eye, 2016). This rose from a budget deficit of 16per cent in the 2014/5 fiscal year, sourced through domestic and external borrowing (Uwiringiyimana, 2015).

Following debt relief in 2005, the Government of Rwanda has steadily increased the country's public debt portfolio. In 2017, the Government's total debt stock stood at US\$2.5billion (Gakunzi, 2017). The table and figure below present the progressive accumulation of public debt between 2006 and 2014.

Table 20: Rwanda: Accumulation of Public Debt 2006-2014

\begin{tabular}{lccccccccc}
\hline & 2006 & 2007 & 2008 & 2009 & 2010 & 2011 & 2012 & 2013 & 2014 \\
\hline Total (million USD) & 748.0 & 901.0 & 941.2 & 1060.7 & 1168.5 & 1414.6 & 1553.2 & 2068.2 & 2398.6 \\
$\begin{array}{l}\text { Foreign currency } \\
\text { (million USD) }\end{array}$ & 479.5 & 569.8 & 665.7 & 736.5 & 777.3 & 984.7 & 1062.3 & 1555.7 & 1760.8 \\
$\begin{array}{l}\text { Domestic currency } \\
\text { (million USD) }\end{array}$ & 268.6 & 331.2 & 275.6 & 311.2 & 368.2 & 301.9 & 387.9 & 465.9 & 562.6 \\
$\begin{array}{l}\text { Guaranteed by the } \\
\text { government }\end{array}$ & 0.0 & 0.0 & 0.0 & 13.0 & 23.0 & 128.0 & 103.1 & 46.7 & 75.2 \\
\hline
\end{tabular}

(National Bank of Rwanda, 2015) 


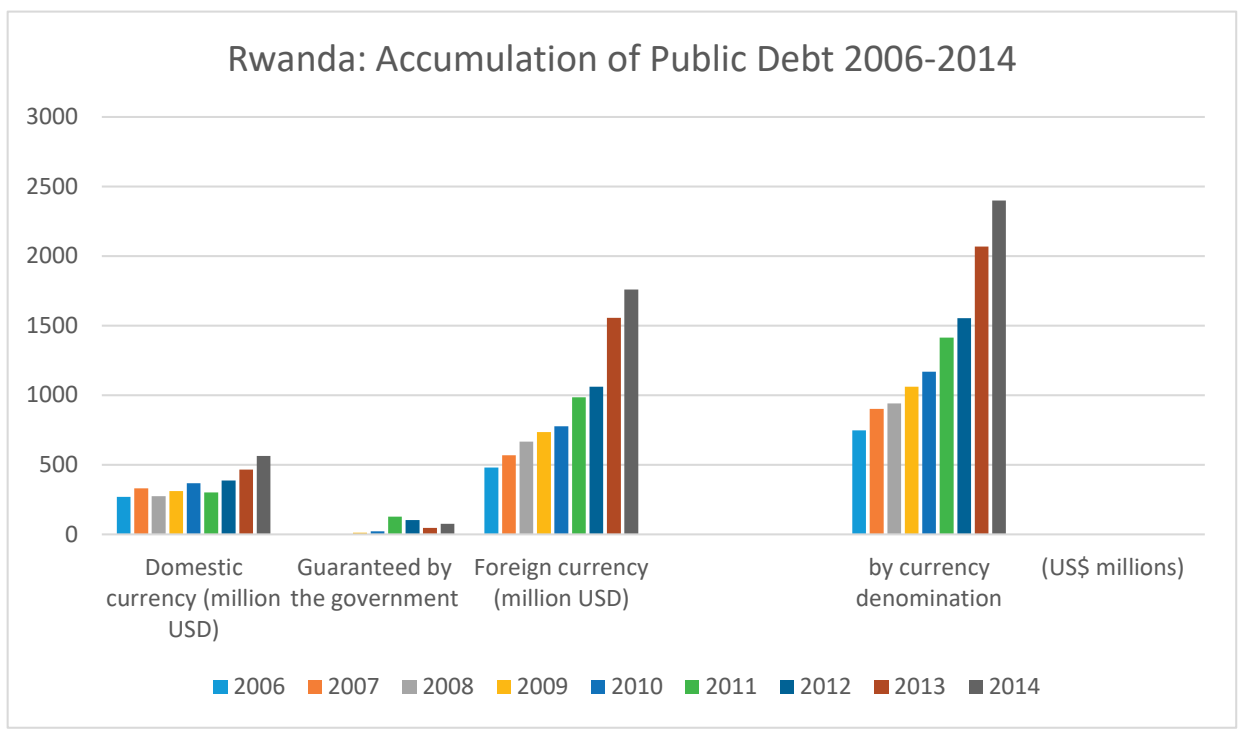

Figure 11: Rwanda: Accumulation of Public Debt 2006-2014

The IMF states that the rise in Rwanda's public guaranteed debt is due to fleet expansion of the State-Owned Airline, RwandAir (International Monetary Fund, 2016). According to the Ministry of Finance and Economic Planning, government guarantees for borrowing are provided only to RwandAir and Rwanda Energy Group (Cassimon, et al., 2016). The Ministry states that between 2012 and 2015, debt finance was deployed into transport, construction, energy, poverty reduction and rural development (Ministry of Finance and Economic Planning, 2015). In 2016, the Government requested a US\$204million, 18month loan from the IMF, to be drawn under the Standby Credit Facility Arrangement. This loan was obtained to buffer foreign reserves (International Monetary Fund , 2016), and ensure the implementation of medium-term policies aimed at addressing external imbalances (New Times, 2016). To obtain this facility, the Government of Rwanda maintained macroeconomic policy performance which aligned with the Policy Support Instrument of the IMF up to the end of 2015, and agreed to higher exchange rate flexibility, a more restrained fiscal policy, and import compression (International Monetary Fund, 2016).

\subsubsection{Debt Composition}

Rwanda's debt stock is sourced mainly from external sources. Domestic debt levels increased between 2006 and 2007, not necessarily due to increased government borrowing, but as a result of reduction of the country's external debt obligations through the HIPC and MDRI processes. The composition of Rwanda's external and domestic debt obligations between 2003 and 2014 are presented in the chart below. 


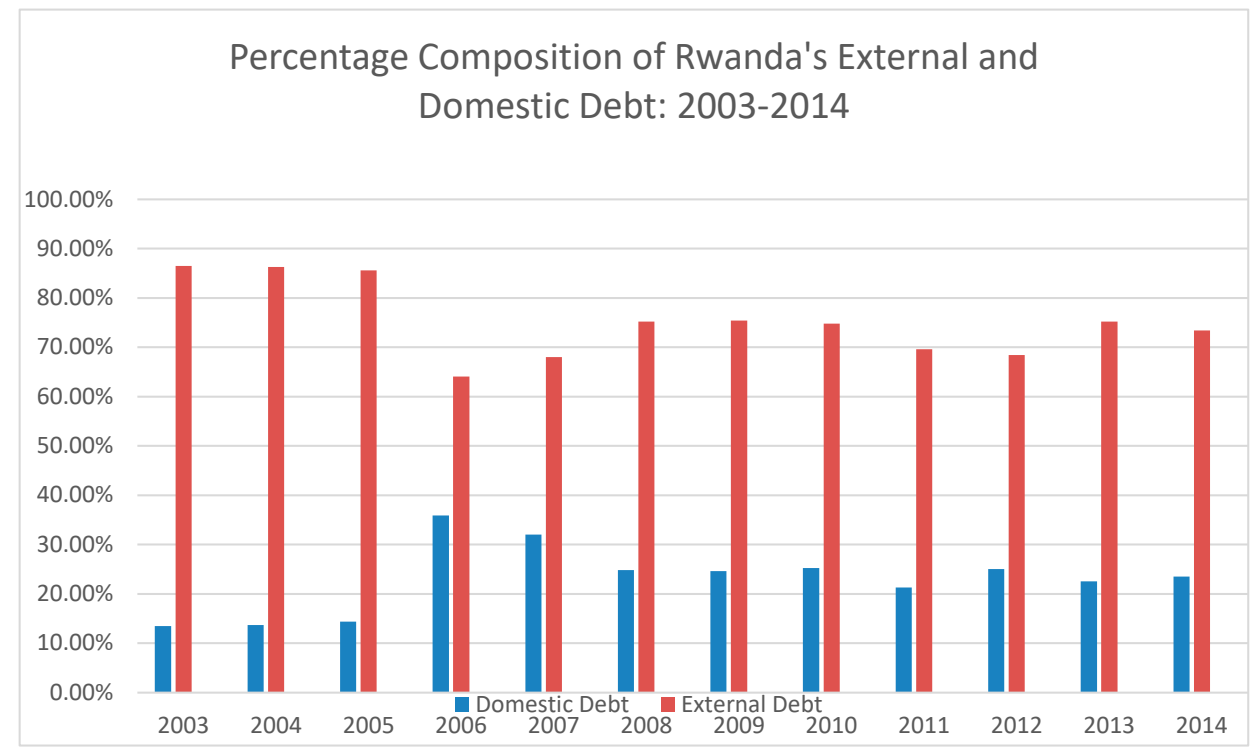

Figure 12: Percentage Composition of Rwanda's External and Domestic Debt: 2003-2014

(National Bank of Rwanda, 2015)

The bulk of Rwanda's external debt obligations are owed to multilateral creditors as shown in the chart below.

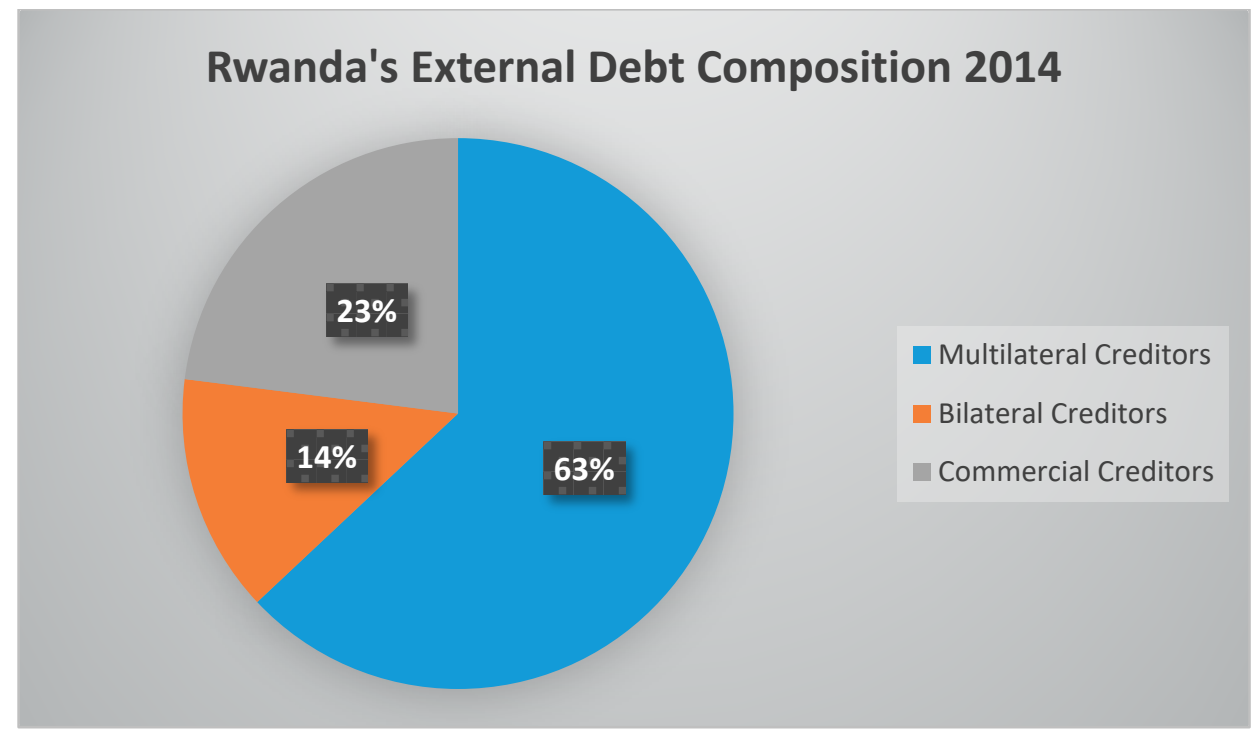

Figure 13: Composition of Rwanda's External Debt 2014

(National Bank of Rwanda, 2015) 
While the Law is silent on the source of debt finance, the Government of Rwanda displays a preference for credit from multilateral sources. This may be due, in part, to historical association, as well as the concessional and long-term character of multilateral debt: in 2015, the International Development Association held 57 per cent of debt, the African Development Bank 22 percent, and the International Fund for Agricultural Development held 8 percent (Cassimon, et al., 2016).

This preference for multilateral debt notwithstanding, Rwanda's portfolio includes credit obtained from bilateral and commercial creditors. Bilateral credit levels increased from US\$89million in 2006, to US\$269million in 2015 (Cassimon, et al., 2016). Prior to the HIPC and MDRI processes, Paris Club creditors held up to 40 percent of bilateral claims on Rwanda. However, since 2006, bilateral credit has been sourced from nonParis Club creditors, such as China and Kuwait, for Government undertakings cofinanced by multilateral and bilateral donors in the infrastructure and energy sectors (ibid).

In 2013, Rwanda entered the commercial debt market through its issuance of a 10year US\$400million Eurobond (Business Day, 2013). Eurobond finance was allocated as follows: US\$120million designated to repay outstanding balances on loans, US\$80million to settle public guaranteed debt owed by RwandAir, US\$150million for the construction of the Kigali Convention Centre, and US\$50million to co-finance a hydropower project.

\subsubsection{Repayments}

A 2014 review by the Ministry of Finance and Economic Planning presents the longterm nature of Rwanda's debt obligations, with the average time to maturity calculated at 11 years. Importantly loans contracted are those with fixed interest rates, which eliminates the incidence of fluctuating or variable obligations (Ministry of Finance and Economic Planning, 2015).

Cassimon, et al., (2016) state that since 2006, bilateral debt service has cost Rwanda less than US\$7million annually, expect for 2013-2014 when it cost US\$10.8million. In the same period, multilateral debt service has been limited due to the grace period and low interest rates of concessional loans. Between 2017 and 2020, it is expected that debt service to multilateral agencies would cost, on average, US\$13.6million annually, which would increase to US\$37.8million annually between 2021 and 2030, and terminate after 2040. Existing commercial (Eurobond) debt service will cost US\$26.5million annually until 2022, and US\$400million in 2023 when the bond reaches maturity.

\subsubsection{Debt Limits}

1. Limits on Borrowing: Article 52 of the Law mandates the Chamber of Deputies to set the annual debt limit while voting in the annual budget. During the budget approval 
process, the Chamber shall also determine the securities that may be given by the Government. Notwithstanding the borrowing limit set by the Parliament of Rwanda, the Minister responsible for Finance may set limits for domestic and external borrowing.

In practice, borrowing limits are set triennially, dependent on the country's debt stock, with reference to the Debt Sustainability Analysis, and based on agreements with the IMF (Gakunzi, 2017). While the Law does not specify measures to enforce government compliance with borrowing limits, it can be argued that the single channel for borrowing (the Ministry of Finance and Economic Planning), as well as the internal mechanisms for public finance management have contributed to the effectiveness of debt limits. Gakunzi (2017) confirms this proposition in stating that debt limits are integrated into the Government's economic planning through the macro framework projection of 3 years agreed with IMF in its Policy Support Instrument program.

2. Debt Monitoring: the Minister responsible for Finance and the National Bank of Rwanda are obligated by Article 56 to "maintain a detailed record of all public debt and Government securities or guarantees on third party debt, as well as the repayment plan under that debt". Additionally, this provision requires the Minister to instruct Public Institutions on the manner by which details and accounts of their borrowing and debt servicing are maintained. Article 53 places the Minister or Chairperson of a Decentralised Entity as the authorities responsible for the service of debt (budget and repayment), as stipulated in the relevant loan agreements. In practice, the Debt Management Unit in the Office of the Chief Economist manages the debt profile database, which is updated on a monthly basis, following consultations with project management units and creditors (Gakunzi, 2017).

3. Debt Management: the responsibility of preparation and publication of a national Debt Management Strategy is given to the Minister by Article 57. This provision mandates the Minister to consult the National Bank of Rwanda in the performance of the debt management function, to avoid conflicts in fiscal, debt management, trade, monetary and exchange policies. The Bank is the designated service provider for the execution of decisions on effective management of public debt. Gakunzi (2017) states that the Debt Management Unit in the Ministry of Finance spearheads the preparation of the annual Debt Management Strategy, and confirms collaboration with the National Bank.

\subsection{Evaluating the Law on State Finances and Property 2013}

The Law on State Finances and Property 2013 can be said to have introduced discipline and accountability into government management of public debt. The Law vests authority to borrow in a single channel, i.e., the Minister of Finance. Also, the government has acquired the competencies and capacity to deliver debt management functions; the 
relevant Government Institutions, i.e., the Debt Management Unit within the Ministry of Finance collaborates with the National Bank of Rwanda throughout the debt management process. It seems that the centralisation of debt management functions has enabled the enforcement of debt management rules: the Ministry of Finance determines government finance needs, recommends debt limits to the Chamber of Deputies, and coordinates activities related to government borrowing. Additionally, the Ministry has further developed regulations and processes which support the Government's approach to public debt management. For example, the Ministry has determined the types of entities and finance for which the Government will provide loan guarantees. In this way, indiscriminate borrowing for other levels of Government is prevented. Importantly, the Government is able to account for the use of debt finance: between 2012 and 2015, debt finance was deployed into transport, construction, energy, poverty reduction and rural development (See 4.5.1). However, challenges remain for Rwanda, particularly, exposure to exogenous shocks, surveillance/conditionalities implemented by creditors, and the role of government in debt management.

1. Exogenous Shocks: the PRSP and budgetary legislation have not necessarily weakened Rwanda's dependence on primary goods for government revenue and expenditure. In the late 1980s, economic contractions which led to the accumulation of public debt were triggered by the fall in international prices of commodity products, tea and coffee, the sale of which formed the larger part of government revenue (See 2.2.2). Three decades later, the 2016 Debt Sustainability Analysis conducted by the IMF noted that weak mineral prices on the international market would lower expected government revenue (International Monetary Fund, 2016). Three years previously, the 2013 Debt Sustainability Analysis jointly conducted by the International Development Association and International Monetary Fund reiterated risks to economic performance arising from the country's narrow export base (International Development Association and International Monetary Fund, 2013). Similarly, a 2012 temporary suspension of aid finance by donors caused a slump in economic growth (International Development Association and International Monetary Fund, 2013; The Economist, 2013).

Thus, while the country has made economic and developmental progress since the HIPC and PRSP processes, there remains a significant challenge of economic diversification and industrialisation. The legal framework, i.e., budgetary legislation does not restrict government use of debt finance, and is placed as a support instrument for the formulation and prosecution of the economic ambitions of the government. It follows that the questions arise to whether, and to what extent, the legal framework can direct, monitor and incubate the process of economic diversification.

2. Surveillance/Conditions of Creditors: in the 1990s, IFIs were criticised for the extent of control they wielded over Rwanda's finances. To illustrate, attached to an IMF facility in the late 1980s were conditions and restrictions as to government expendi- 
ture (See 2.2.2). Similarly, Rwanda's loan from the 2016 Standby Credit Facility from the IMF was accompanied by conditions on economic policy. Rwanda's borrowing arrangements results in its economic arrangements closely monitored and influenced by IFIs. Thus, it is necessary to question the extent to which the Government is able to determine and implement economic policy. Also, the issues on state sovereignty and consent of the citizenry can be raised, especially as these concern public borrowing (See 2.3 and 2.4.1).

3. Government-Heavy Debt Management: per the Law, the institutions which perform debt management functions are those of the Government, and those directly concerned with public finance management, i.e., the Ministry of Finance and the National Bank of Rwanda. The role of Parliament is limited to the review and approval of borrowing requests. The Law does not incorporate stakeholders, e.g., communities, or the private sector into the system for public debt management. Thus, it becomes necessary to investigate the strategies which would allow other actors contribute to functions of public debt management. It may be useful for the Ministry of Finance to establish a system to evaluate the impact of debt finance within sectors of the economy. Impact evaluation which incorporates Private Sector and Civil Society comments on the impact, benefits and limitations of undertakings financed by debt, will provide useful insights on the acquisition and deployment of debt finance.

\subsection{Discussion: Legal Reforms for Debt Management and Debt Sustainability}

Budgetary legislations have led to the integration of transparent and systematic mechanisms for the management of public debt in Nigeria and Rwanda. The legislations in both countries (Fiscal Responsibility Act 2007 in Nigeria, and the Law on State Finances and Property 2013 in Rwanda) are similar in prescription, i.e., rules to govern debt acquisition, and to direct government management of debt portfolios. Also, the laws place the Minister, and by extension, the Ministry of Finance as the 'engine-room' of debt management and economic development. Additionally, the tools and approaches for public debt management are identical, e.g., Debt Sustainability Analyses and debt monitoring databases. The similarities in the debt management systems of Nigeria and Rwanda are presented in the table below: 
Table 21: Public Debt Management Provisions of Budgetary Legislation in Nigeria and Rwanda

\begin{tabular}{|c|c|c|}
\hline Rule-Type & Nigeria & Rwanda \\
\hline \multicolumn{3}{|l|}{ Positive Obligations } \\
\hline 1. Debt Limits & Yes & Yes \\
\hline $\begin{array}{l}\text { Establish Limits for } \\
\text { Government Borrowing }\end{array}$ & $\begin{array}{l}\text { Assigned to: President (not an } \\
\text { institution) } \\
\text { Implemented by: } \\
\text { Debt limits have not been established } \\
\text { Debt Management Office which } \\
\text { recommends limits in the annual Debt } \\
\text { Sustainability Analysis. These } \\
\text { recommendations are not binding. }\end{array}$ & $\begin{array}{l}\text { Assigned to: Chamber of Deputies when } \\
\text { voting in annual budget } \\
\text { Implemented by: Ministry of Finance which } \\
\text { sets limits triennially } \\
\end{array}$ \\
\hline $\begin{array}{l}\text { Enforcement of } \\
\text { Compliance }\end{array}$ & $\begin{array}{l}\text { Assigned to: Fiscal Responsibility } \\
\text { Commission }\end{array}$ & Not assigned \\
\hline 2. Debt Monitoring & Yes & Yes \\
\hline $\begin{array}{l}\text { Database of Government } \\
\text { debt }\end{array}$ & $\begin{array}{l}\text { Assigned to: National Assembly, } \\
\text { Central Bank and Debt Management } \\
\text { Office } \\
\text { Implemented by: Debt Management } \\
\text { Office }\end{array}$ & $\begin{array}{l}\text { Assigned to: Ministry of Finance and } \\
\text { National Bank of Rwanda } \\
\text { Implemented by: Debt Management Unit in } \\
\text { the Ministry of Finance and Economic } \\
\text { Planning }\end{array}$ \\
\hline 3. Debt Management & Yes & Yes \\
\hline $\begin{array}{l}\text { Debt Sustainability } \\
\text { Analysis }\end{array}$ & Silent & $\begin{array}{l}\text { Assigned to: Minister of Finance } \\
\text { Implemented by: Debt Management Unit in } \\
\text { Ministry of Finance and Economic Planning }\end{array}$ \\
\hline Repayments & $\begin{array}{l}\text { Federal Government and Contracting } \\
\text { Government }\end{array}$ & $\begin{array}{l}\text { Minister of Finance and National Bank of } \\
\text { Rwanda }\end{array}$ \\
\hline \multicolumn{3}{|l|}{ Procedural Rules } \\
\hline \multirow[t]{2}{*}{ 4. Authority to Borrow } & Yes & Yes \\
\hline & $\begin{array}{l}\text { External debt: Ministry of Finance } \\
\text { Domestic debt: other Governments }\end{array}$ & All debt: Minister of Finance \\
\hline $\begin{array}{l}\text { Approval of government } \\
\text { borrowing }\end{array}$ & External debt: Parliament & All debt: Parliament \\
\hline Compliance & Ministry of Finance and Parliament & Ministry of Finance and Economic Planning \\
\hline \multirow[t]{2}{*}{ 5. Purpose of Borrowing } & Yes & Yes \\
\hline & $\begin{array}{l}\text { Capital expenditure and human } \\
\text { development }\end{array}$ & $\begin{array}{l}\text { To finance the annual budget deficit, to } \\
\text { refinance maturing debt or a loan paid } \\
\text { before redemption date, to boost foreign } \\
\text { currency reserves, to maintain balances on } \\
\text { a bank account of the consolidated fund, to } \\
\text { regulate monetary conditions should the } \\
\text { need arise, and for any other purpose } \\
\text { necessary for sound fiscal policy and } \\
\text { effective debt management }\end{array}$ \\
\hline
\end{tabular}

While it is the National Parliaments of Nigeria and Rwanda that enacted the budgetary legislations, the similarity of these laws, both birthed through the PRSP process gives 
credence to claims that the World Bank and IMF prescribe uniform policies on borrower countries without due regard for circumstances and context (See Chapter 3). Also, these similarities validate a criticism of NIE-inspired legal reforms, i.e., that reforms are benchmarked against 'ideal' or 'good' legal systems (Milhaupt, 2009; Siems, 2011; See 1.4). Crucially, the limitations of this approach are manifest in both countries: debt management is government-centric, reflective of the governance and 'institutions matter' perspective of IFIs. While public finance is rightly the responsibility of government, the legal and institutional frameworks created by the PRSP and budgetary legislations do not incorporate other stakeholders into the mechanisms for the management of public debt. All functions- debt acquisition, use, management and monitoring are to be performed by governments. There is the danger that this centralization of authority, functions and responsibility can lead to insularity in government and exclusion of other parties, rather than accountability and transparency, as governments do not need to consult or engage with stakeholders over public finance or public debt. Indeed, government may rely on legal instruments to ward off queries as to the use of debt finance, provided they satisfy the obligations arising from budgetary legislation. These obligations are procedural in nature, e.g., debt databases and parliamentary approval for debt acquisition, and do not necessarily require accountability or reporting on the use of debt finance.

Interestingly, budgetary legislations do not consider the potential of other arms of government, e.g., ministries and departments responsible for the delivery of social services, to contribute to the management of public debt. This is somewhat contradictory, as the PRSPs and debt relief were premised on the utilisation of financial resources for national development. The perspectives, capacities and experiences of other arms of government, as well as stakeholders such as communities and the private sector, directly engaged in the design and management of social development undertakings would improve the efficacy in the acquisition and use of debt finance.

Economic diversification was stated as a primary objective in the PRSPs of Nigeria and Rwanda. The Governments of both countries pledged to undertake structural, institutional and policy reforms towards the structural changes of their economies. These reforms were also intended to reduce dependence on primary products for revenue (See 3.2). However, in 2015, a decade after debt relief was obtained by Nigeria and Rwanda, the economies of both countries remain vulnerable to economic shocks. Also, both countries continue to depend on revenue from the export of commodities/primary goods, for a significant proportion of government revenue (See 4.4 and 4.6). The combination of structural weaknesses and debt accumulation pose very real threat of unsustainable debt, despite IMF rankings of the debt portfolios of both countries. Put simply, if the governments of both countries continue to borrow, and significant economic transformation does not occur, then the accumulation of unsustainable debt portfolios is inevitable. From a legal perspective, it becomes imperative to interrogate the mechanisms, frameworks and rules which can effectively support the Governments 
of Nigeria and Rwanda, towards the prevention of a repeat of the debt burden of the 1980s and 1990s.

The investigation of Nigeria and Rwanda reveals the interplay of law and institutions in economic development. At international level, IFIs have consistently enforced and applied their policies on countries, while country-level institutions in Nigeria and Rwanda have reflected and implemented the values and objectives of the overarching agenda of Governments. Several observations can be made in this regard; firstly, institutions are flexible to different purposes and amenable to utilisation by divergent schools of thought. Thus, institutions, i.e., organisations, require a guiding philosophy and overall objective to shape activities and approach. Laws and legal instruments have shown to be useful mechanisms for the creation of institutional agenda and formulation of work approaches: budgetary legislations in Nigeria and Rwanda have created thematic agenda and operational maps for the Governments of both countries. Secondly, institutions do not exist in a void; they are the product of institutions, even as they create other institutions. The interplay of law and institutions present a dynamic process of interaction, creation and recreation. For example, the Governments of Nigeria and Rwanda enacted laws, which create new institutions, such as organisations, e.g., Debt Management Offices, and mental constructs, such as Debt Sustainability Analyses. In the context of public debt management, and economic development, laws can better contribute to the achievement of objectives where they consider outcomes, in addition to procedures and behaviours. An outcome-lens will galvanise institutions towards results and effectiveness. For example, legal frameworks which monitor the utilisation of debt finance can obligate governments to pursue economic transformation through measurements of the extent of economic dependence of debt finance and revenue from other sources on a regular basis. Also, legal frameworks can support the inclusion of stakeholders in debt management systems through mechanisms which consider their perspectives in the conceptualization and utilisation of debt finance in socially related undertakings.

\subsection{Summary}

Legal reforms have proved useful for the management of public debt in Nigeria and Rwanda. Budgetary legislations have created predictable and objective mechanisms, which have been adopted by the Governments of both countries. While these legal instruments have effectively directed government behaviour in the area of public debt, they have not necessarily led governments to adopt practices which would lead to sustainable debt portfolios. The accumulation of an unsustainable debt burden is a real threat for both Nigeria and Rwanda, as the structure of their economies have not fundamentally changed since debt relief, even as they continue to borrow heavily to support government expenditure. 
IFIs continue to wield significant influence in the economies, economic policies and governance systems of Nigeria and Rwanda. Through conditionalities, processes, tools for economic analyses, and templates for economic management, the ideology and agenda of the World Bank and IMF are manifested in the economies of borrower countries. Also, these institutions are rightly criticised for their prescriptive and uniform approaches, which are macroeconomic in perspective and emphasis.

The case-study of Nigeria and Rwanda presents the gap, and opportunity for law to function as a driver of economic development in Africa. Legal instruments and frameworks can direct institutions towards the conceptualization of objectives, and direct the operations and undertakings of government, as well as other stakeholders, for the purpose of economic development. To do so, laws must carefully consider the intended outcomes of economic development, and directly support activities and undertakings through the provision of frameworks and tools, as well as results-oriented guidance for institutions. The next chapter expands upon this proposition, and presents strategies by which laws can contribute to the economic development of African countries. 
Chapter

\section{Discussion: \\ Law, Institutions and Economic Development}



In the preceding chapters, I discussed the political, economic and institutional contexts in which Nigeria and Rwanda accumulated debt burdens. Also, I presented the debt management policies of the World Bank and IMF between the 1970s and mid-2000s, and the implementation of these policies in Nigeria and Rwanda as borrower countries. Thereafter, I evaluated the effectiveness of legal reforms for public debt management in Nigeria and Rwanda.

This chapter begins with an examination of the arguments made in the first chapter of this thesis, i.e., that while the NIE school of thought has had a profound influence on contemporary development practice, it has left important questions unanswered. In Section 1.4, I highlighted five gaps which limit the effectiveness of legal reforms influenced by NIE: 1) the narrowness of and investor-centric approach to NIE thinking, 2) the lack of agreement on the definition of institutions, 3) the argument as to whether institutions drive or are derived from economic development, 4) faulty benchmarking of legal reforms and 5) the insufficiency of econometric indices for proper analysis of the effectiveness of laws (See 1.4). Thereafter, in the second part of this chapter, I review the three research questions which guided the investigation of this thesis. I undertake a comparative analysis of the reforms in Nigeria and Rwanda to test the effectiveness of the policy thrust which led to the use of legislation to manage public debt. In the third section of this chapter, I propose that evaluations of laws and legal instruments are undertaken from the perspective of their outcomes and effect within economies. I submit that the debate on causation, i.e., proving a clear link between laws and economic performance, emanates from the ambiguity in the definition of legal terms, as well as the problems of benchmarking legal interventions. I argue that evaluating law on the basis of outcomes, which are determined by the stated objectives of economic development, will enhance the conceptualisation of legal reforms, and render them more suitable and relevant for contexts. Also, an outcome-focused approach will address the gaps in current assessment methods, e.g., comparative econometric indexes, which are yet to provide knowledge on how countries may undertake the conceptualisation and application of legal instruments for economic development. Whereas the current approach is to evaluate legal and institutional systems against fixed benchmarks, the outcome-based approach accepts the evidence of these constructs as a starting point- to observe and analyse the interactions of law and institutions in the pursuit of stated goals.

\subsection{Revisiting the Theoretical Point of Departure: Limitations of Legal Reforms Influenced by New Institutional Economics}

This thesis is premised on the assertion that laws and legal systems manage, influence and contribute to the developmental processes of economies. The point of departure 
was taken from observations of the limitations and criticisms of NIE, and the legal reforms which emanate from its line of thinking.

The first criticism of NIE posed in this thesis is that its perspective and concerns are narrow, and do not incorporate multiple perspectives or approaches (See 1.4). Davis and Trebilcock (2008), argue that NIE-influenced legal reforms resemble those previously promoted by modernisation theory, i.e., the creation of legal systems which aid private commercial activities, supported by institutions which are predictable and stable in the delivery of their functions. To some extent, this thesis has validated this criticism: the case-study of Nigeria and Rwanda reflects the NIE emphasis on governance/rule of law/institutions, as well as the necessity of good quality laws to aid the delivery of governance. However, NIE does not necessarily prescribe a singular route to the utilisation of laws and institutions for economic development. As stated in Chapters 1 and 2, IFIs are influenced by NIE in their implementation of the governance/rule of law agenda. However, the prosecution of this agenda by IFIs has been coloured by institutional agenda and frameworks. The case-study has shown that the IMF and World Bank, principal lenders and guarantors of debt acquired by the Governments of Nigeria and Rwanda, through the PRSPs and technical assistance, sought to create procedures which render government borrowing predictable and transparent. The debt management provisions of budgetary legislations adopt a macroeconomic bent, focused on the creation of mechanisms to regulate government borrowing, even as the provisions prescribe the use of quantitative tools, e.g., databases to monitor public debt portfolios. Debt sustainability analysis are macroeconomic and quantitative in nature, and do not focus on the qualitative utilisation or impact of debt finance on national economic development (See 3.2 ; 3.3; 3.4). However, it can be argued that monitoring the use of debt finance is the responsibility of governments, rather than IFIs. In the 1980s and 1990s, IFIs prescribed SAPs which were concerned with improvements in the economic performance of countries, and did not consider the effects of programs on societies, e.g., social dislocations caused by reduced government spending on social services. SAPs were criticised for their intrusive approach, by which conditionalities interfered with the sovereignty of national governments (See 2.2). Thereafter, the HIPC Initiative changed the policy approach of the World Bank and IMF, and emphasised a countrydriven approach to reforms. In the 2000s, under the HIPC Initiative, PRSPs guided much more wide-ranging reforms which were criticised for increasing surveillance on borrower countries. Thus, while it is countries that shaped and implemented reforms, the IFIs determined the standards by which country-led reforms were measured and assessed (See 3.1.1). The World Bank and IMF are primarily international finance institutions, concerned with global economic stability. Both institutions have adopted and facilitated the global development agenda through the MDGs and SDGs, but it has been necessary for them to stay true to their mandates, as stated in their articles of incorporation (See 2.12 and 2.1.3). 
The second problem identified with the NIE approach to economic development is the fluidity of boundaries between institutional thought and other fields. This challenge was encountered in this study: Douglass North's definition of institution is all encompassing (North, 1995), as laws, government agencies, social norms, dynamic relational mechanisms of all these, and their outcomes are all captured as institutions. However, in the prosecution of the study, it was necessary to distinguish between laws/legal frameworks/legal instruments, and institutions (organisations and mental constructs), treating each as separate, distinct entities, even as their interplay and outcomes are acknowledged and investigated. The argument made by Ulen (2011), that government power and political will are useful substitutes for a legal system was tested, and found to be accurate; in the 1980s and 1990s, the Governments of Nigeria and Rwanda adopted and implemented SAPs and PRSPs without recourse to domestic laws. These programs were prosecuted by government will and intention. Importantly, this thesis challenges the claim made by Ulen (2011) that it is not possible to show causality, i.e., direct effect of law on economic performance. The reforms in Nigeria and Rwanda show the influence of law on government behaviour, and by extension on the sustainability of public debt portfolios in Nigeria and Rwanda. This study has agreed with NIE, and Law and Development arguments that laws can be described as institutions (North, 1995; Acemoglu, et al., 2001; Acemoglu \& Robinson, 2012; Djankov, et al., 2006; Harris-White, 2003; World Bank, 2017), as they do frame the environments and thought processes which shape the pursuit and outcomes of economic development. Furthermore, laws operate as benchmarks and signposts, which guide the activities and functions of other institutions. In the case-study, budgetary legislations define the powers, responsibilities and functions of institutions in government for public debt management. The legislations also set the standards of operation for these government institutions, even as they frame the relationships between different institutions of government. Law must necessarily be definitive and take a holistic perspective of its remit. In contrast, the remit of institutions (organisations) is narrower, and tied to the delivery or supervision of specified objectives and outcomes, pursued through fluid and dynamic activities.

Disagreement as to whether institutions, such as they are defined, are the drivers or outcomes of economic development was highlighted as the third limitation of NIE. De Soto (1989) argued in 'The Mystery of Capital' that the legal system is the primary differentiator between industrialised and developing countries. Similarly, Acemoglu et al. (2001) argued that the extractive nature of institutions in former colonies have prevented economic development. In contrast Chang (2007) posited that institutional development will occur in tandem with economic development. In this study, it was shown that debt relief reduced the size of government debt portfolios, which improved the economic positions of both countries. Through the PRSP process, budgetary legislations were introduced into government systems for the management of public finance. These legislations have improved the processes and mechanisms by which governments manage public debt (See 4.4 and 4.6). In this way, law- a type of institution, has enhanced 
the functions and performance of government institutions. The interaction or workings of both institution types contribute to predictability in public debt management. Based on the investigation of Nigeria and Rwanda in the preceding chapters, it can be argued that institutions do influence the outcomes of economic development. It follows that they also can be inhibitors of economic development, as shown through the limitations of budgetary legislations (See 4.4 and 4.6). Thus, institutions matter. Nonetheless, it is perhaps more important to emphasise the suitability and effectiveness of institutions to the purposes for which they are deployed. Rather than focus only on whether institutions are good or bad, it may prove more useful to investigate whether laws and institutions do deliver outcomes which support the achievement of economic objectives.

In this regard, the fourth problem identified with NIE, i.e., benchmarking of legal systems is pertinent for law as an instrument of economic development. This thesis has agreed with Milhaupt (2009) that legal reform efforts have suffered from poor benchmarking. Budgetary legislations in Nigeria and Rwanda are near identical (See 4.7), and clearly are modelled on rules present in western systems, such as those found in the European Union (See 3.2). The debt management provisions of budgetary legislations do provide benefits for debt portfolio management, including predictability, improved portfolio management, and due process, as outlined in Chapter 4 of this thesis. However, the legislations are limited in that they do not directly address the political-economic systems of both countries: for example, in Nigeria, external borrowing is more tightly controlled than domestic borrowing, with the result that the domestic debt portfolio has increased annually since 2005, and is significantly larger than the external debt portfolio (See 4.2). Also, in both Nigeria and Rwanda, debt management stipulations do not require governments to account for the use of debt finance (See 4.7), even though misuse of loans in the 1970s and 1980s was a factor which led to the unsustainability of debt (See 2.2.1 and 2.2.2). It would prove better for legal reforms to be based on thorough evaluations of the problem(s) they seek to solve, as well as analyses of the political, economic and social elements relevant to the context of intervention. Furthermore, legal systems do create and influence changes to relationships between institutions, power structures, and economic systems. Thus, legal reformers must adopt an interdisciplinary perspective, and incorporate political and sociological tools of analysis in the conceptualisation of legal reforms, even as economists have incorporated laws and legal frameworks into NIE. However, the question then becomes- whose responsibility is it to integrate these approaches into legal reforms? In Nigeria and Rwanda, the legal underpinnings for public finance management were adopted as part of the PRSP-related reforms, and National Parliaments drafted, debated and enacted budgetary legislations. Thus, it would seem that it is at domestic level that the adaptation of 'standard-form' legal reforms for suitability and relevance can best be considered.

The fifth criticism of NIE is directed to the limitations of the econometric approach to the measurement of laws and institutions. The investigation conducted into the debt management systems of Nigeria and Rwanda validates this criticism. For example, the 
Country Policy and Institutional Assessment (CPIA) of the World Bank states that the scores given by country teams reflect a variety of indicators, values and judgment, and "higher scores can be attained by a country that, given its stage of development, has a policy and institutional framework that more strongly fosters growth and poverty reduction" (World Bank, 2017). On the CPIA, and other indexes used by the World Bank, e.g., Doing Business, countries are given scores or points according to a scale, which measures the existence and implementation of their policies (ibid). Indeed, the World Bank wrongly rates Nigeria higher than Rwanda in the area of debt policy. Rwanda's debt policy between 2006 and 2012 was ranked at 3.5. In 2005, prior to the enactment of the budgetary law in 2006, the country's debt policy scored 3.0. Note that the budget law was revised in 2013, at which point the country gained the score of 4.0 (World Bank, 2017). Between 2013 and 2016, Rwanda's debt policy has been ranked 4.0 (out of 6 ) on the Country Policy and Institutional Assessment. In contrast, Nigeria's debt policy was scored 3.5 in 2005, and in 2006 (ibid). Nigeria's debt policy since 2007, has been ranked at 4.5 out of 6, except for scores of 4.0 in 2011 and 2012 (ibid). Note that the Fiscal Responsibility Act was enacted in 2007. However, the investigation of this thesis reveals weaknesses in the management of Nigeria's public debt, as compared to those of Rwanda: State Governments in Nigeria borrow without recourse to the Federal Government, which has resulted in high domestic debt liabilities. Also, limits for government borrowing have not been set. As such, the relevant authority is unable to enforce compliance with limits on borrowing (See 3.3.3). In contrast, government borrowing in Rwanda is centralised, and the Government publishes limits on borrowing on a 3year basis. Importantly, Decentralised Authorities are not permitted to borrow without the approval of the Minister responsible for Finance (See 4.5.1). Also, the Government of Rwanda has been better able to report on the use of debt finance: the National Airline, the Kigali Convention Centre and other infrastructural projects have been kick-started through government borrowing (See 4.5.2). Thus, I would argue that reliance on indexes in themselves, as indicators of 'good' or 'bad' policy, or as evidence of good institutions/government performance is faulty, and does not capture accurate economic or policy positions. Riegner (2016) has criticised the methodology used by the World Bank to score and rank countries; he argued that the questionnaire is developed within the Bank, and does not incorporate the views of other stakeholders. As discussed in the investigation of Nigeria and Rwanda, 'good' laws and policies do not necessarily lead to good economic outcomes (See Chapter 4). Importantly, indexes do not enable a proper or holistic understanding of the context. Instead, I would posit that econometric and quantitative analyses are more useful when placed in the context of qualitative discussion.

However, in qualitative discussion, it is not straightforward to identify and resolve the gaps between policy and outcome: is the problem with NIE school of thought? Conversely is the gap in outcome created by interpretations of NIE by the World Bank and IMF, or is it implementation of IFI prescriptions within countries? 
While the original Law and Development movement was focused on education and skills provision for lawyers and judges, as well as the creation of an academic field (Trubek, 1996), NIE further extended the discourse on the role of Law in Development through its assessments of the quality of laws and institutions (Acemoglu \& Robinson, 2012; Acemoglu, et al., 2001; Djankov, et al., 2006; Kaufmann, et al., 1999). However, the governance and rule of law agenda have not specified routes for countries to successfully acquire good laws or institutions that support economic improvement (Andrews, 2013). Thus, it has been that NIE has spearheaded a school of thought which points to better performing economic systems and their legal arrangements as those which are supportive of growth. As such, NIE-inspired legal reforms have led to the transplantation of legal systems of advanced economies into developing countries.

On the other hand, the gap between good policy and good outcomes can be considered from the perspective of IFIs. NIE provides the ideological underpinning for the governance and rule of law agenda, which ignited interest and debate in governance, and reintegrated law into the international development discourse in the 1990s. The World Bank and IMF have promoted governance and the rule of law as necessary elements for development, even as they have supported, conceptualised and financed legal reforms globally. However, it may be that the adoption and utilisation of indexes by IFIs contributes to the seeming disconnect between policy/laws and economic outcomes. Indexes developed and used by the World Bank have been severely criticised: it has been reported that up to 85 per cent of global policy-makers utilised the World Bank's Doing Business Index as a reference (Biron, 2013). Nonetheless, a review panel convened by the World Bank President in 2013 recommended the removal of country rankings, and particularly the removal of aggregate tables which "cloud crucial countrylevel variations" (ibid).

The case of Zambia illustrates the importance of qualitative context in the use of quantitative indices: in 2012 that Zambia had adopted reforms based on the Doing Business Index, which led to workers being taxed at 25 per cent, and corporations taxed at 16 per cent. In 2011, Zambia was ranked $8^{\text {th }}$ on the access to credit indicator, even though 90 per cent of small and medium sized enterprises in the country reported that they were unable to access credit at interest rates lower than 25 per cent (The Guardian, 2012). In similar vein, trade unions and campaigners have lobbied for the Doing Business Report to be scrapped, on the basis of flaws in its methodology, particularly use of "flawed and controversial indicators as the basis of its rankings" (Global Policy Forum, 2014 ). Labour groups have argued that the 'employing workers indicator' promotes labour reforms which deteriorate working rights, conditions and wages, even as the indicators for corporations are described as retrogressive (ibid). Antonio Gambini, a researcher at CNCD-11.11.11, the Belgian francophone umbrella organisation for development non-governmental organisations argued thus: 


\begin{abstract}
"Against a growing realisation by the public and international organisations such as the IMF and the OECD that tax systems are increasingly dysfunctional and regressive, and that big corporations increasingly manage to avoid bearing their fair share of taxes to contribute to collective expenses, the DBR is still advocating massive tax cuts for corporations, based on questionable data provided by partial and biased actors in the tax debate such as Price Waterhouse Coopers (PWC). Corporate tax payments are, alongside job creation and technology transfer, one of the most important contributions to poverty eradication and fighting inequality that developing countries depend on. Promoting this indicator for corporate tax is setting us two steps back for every one we advance in the fight for better domestic resource mobilisation" (ibid).
\end{abstract}

From a different perspective, the weak link between legal reforms and economic may be found at country-level implementation of reform programs. During the SAP era, the World Bank asserted that economic reforms were hindered by the poor commitment of national governments (World Bank, 1994). A decade later, the HIPC process transferred the burden of reform design and implementation to countries (International Monetary Fund, 1999). The intellectual and institutional influence of IFls cannot be denied; in the context of debt relief, it was the World Bank and IMF that set the benchmarks of good policy, laws, and institutions, even as they assessed and approved reforms which qualified countries for debt cancellation (See 3.1.2). Nonetheless, it is national parliaments and legislatures that create and amend legal instruments and institutional frameworks. As such, it can be argued that countries could render legal reforms more suitable to their contexts and developmental agenda during the law-making process. However, it is necessary to ask whether countries have the intellectual resources, and opportunity to amend orthodox reform programs; how will countries overcome resistance from the intellectual stature of IFIs if they choose to deviate from widely accepted norms and approaches to legal reform? Similarly, why would developing countries choose to deviate from orthodox approaches to legal reform- the adoption of good laws and institutional arrangements lead to higher scores on the indexes (Doing Business, CPIA) which state global economic competitiveness. Higher scores result in better and improved rankings, which improve opportunities for investment and access to financial resources from the international financial system.

All these questions are relevant in the evaluation of the legal reforms adopted by Nigeria and Rwanda for debt relief. The complexity and interrelated nature of NIE, IFI and country-level implementation serve to complicate the evaluation of the effectiveness of budgetary legislations. Nonetheless, the next section proposes an approach which is intended to enhance the effectiveness of legal reforms in African economies. 


\subsection{Proposition: Evaluate Law Against Outcomes}

In this section, I expand upon the argument that the limitations of budgetary legislations can be attributed to 1) benchmarking of legal reforms, and 2) the systems for the evaluation of laws as they relate to economic performance.

\subsubsection{Problems with the Benchmarking of Legal Reforms}

As discussed in the investigation of Nigeria and Rwanda, economic and legal reforms prescribed by IFIs to borrower countries are often similar, and modelled on the laws of advanced economies. Nonetheless, the concept of legal transplants is not unique to developing countries: Watson (1991) states that legal transplants are the most common form of legal change (Watson, 1991). Helen Xanthaki has explained that western legal draftsmen will often look to countries with a similar legal system, language and legal tradition as a starting point, to assess the extent to which chosen solutions blend with international practice (Xanthaki, 2008). Additionally, the comparison of legal systems and their effects on economic performance is not a novel phenomenon. While NIE can be described as a successor to the Law and Development movement of the 1960s, comparative analysis of law and economics, or law and governance has occurred for several centuries: in the $18^{\text {th }}$ century, Adam Smith wrote 'The Wealth of Nations', a discussion of economic policies of European countries, and the implications in the international trading system (Smith, 1776). In the same century, Montesquieu explored the relationship between laws and governance in his book 'The Spirit of the Laws', in which he argued against legal transplantation on the grounds of national context (Montesquieu, 1750). Two centuries later, Max Weber in his book 'Economy and Society' outlined various areas of interplay between law and economic systems. Weber argued that administrative actions be embodied in formal law, and enacted by the legislature. In his view, budgets as programs of public revenue and expenditure should thus be underpinned by legislation (Weber, 1968).

In 1993, Alan Watson defined a legal transplant as "the moving of a rule or a system of law from one country to another or from one people to another" (Watson, 1993, p. 21). Following this line of thinking, Nuno Garoupa and Anthony Ogus described legal transplants as the unilateral adoption of legal norms from other jurisdictions (Garoupa \& Ogus, 2006). Berkowitz, et al., (2001) review historical transplantation of legal codes over the last two hundred years, which they organise into three waves: firstly, between 1890 and 1914, during which French law was exported throughout Europe, and then British and French Law exported into colonies. Secondly, in the immediate period following the Second World War, many newly independent countries borrowed the legal systems of major western countries. In this period, laws were borrowed from the United States, as well as those European countries which were former colonial powers. Thirdly, from the 1980s, especially after the disintegration of the former Soviet Union, 
legal reforms were implemented in former Soviet countries. These reforms were modelled on the legal systems of the United States and European countries.

In their discussion of Japanese Financial Law, Hideki Kanda and Curtis J. Milhaupt state that legal transplants "can range from the wholesale adoption of entire systems of law to the copying of a single rule" (Kanda \& Milhaupt, 2003, p. 887). To explain the proliferation of legal transplants, Kanda and Milhaupt (2003), point to the ease with which transplants occur, as well as the political element or impetus, which is often external, such as colonisation or military occupation. Also, they point to the nature of legal transplantation, which is the domain of the legal profession, i.e., lawyers and judges, who look to other sources of 'authority' (ibid). In Africa, from the mid-1980s, SAPs were accompanied by legal reforms for privatisation and institutional strengthening (See Chapter 2). Thereafter, the PRSP processes integrated legal and institutional reforms (See Chapters 3 and 4).

According to the World Bank, "it is generally recognized that there are strong links between the rule of law, economic development, and poverty reduction, and that therefore the World Bank and organizations with comparable mandates should make promoting the rule of law a priority" (Legal Vice Presidency, World Bank, 2003, p. 9). The World Bank organises legal reforms into three categories: reforms of laws, demandside reforms which are concerned with the internal and systemic operations of institutions, and supply-side reforms which address access to institutions, and the quality of their performance. Interestingly, the Legal Vice-Presidency of the World Bank has noted that transplantation of laws from abroad, though appealing, may be unsustainable if they are irrelevant to the local context: "fostering public understanding and ownership of the proposed laws ensures that they are suitable for the economic, social, and legal climate, and thereby facilitates subsequent compliance by the public at large" (Legal Vice Presidency, World Bank, 2003, p. 6). However, it can be argued that the extent to which the public can claim ownership of institutions which originate from external institutions is debatable.

Legal transplants have provoked much discussion and debate: in 1974, Otto KahnFreund was alarmed at the prospect of using foreign models as instruments of social or cultural change (Kahn-Freund, 1974). Countering in 1976, and advocating for legal transplants, Alan Watson argued that "whatever their historical origins may have been, rules of private law can survive without any close connection to any particular people, any particular period of time or any particular place" (Watson, 1976, p. 81). In more recent discourse, Pierre Legrand, asserted that legal transplants are 'impossible' on the basis that rules are necessarily based within a specific context (Legrand, 1997). However, this position is challenged by current international development practice: current methods of economic and legal evaluation, e.g., Doing Business and CPIA, place countries in a competition or in a race to adopt 'ideal and good' laws. As Daphne Barak-Erez notes, "inspiration from foreign legislation is sometimes the result of competition, usu- 
ally economic competition, between countries. States vie with one another for investments and new economic initiatives" (Barak-Erez, 2014, p. 19).

From the perspective of African legal and economic development, I would argue that it is possible to view transplants as a reality of existence, as a result of several waves of legal reform from the pre-colonial era. As such, the relevant question then becomeshow should the effectiveness of legal reforms be evaluated?

\subsubsection{Problems with the Evaluation of Laws}

Orthodox development perspectives have measured the good qualities of law against ideal metrics, which informs the current approach to legal reform for economic development, i.e., to transplant laws or characteristics of ostensibly ideal legal systems into developing economies. These economies are then evaluated using econometric indices which measure the quality of their laws and institutions: For example, the African Development Bank describes its CPIA Assessment as a:

"diagnostic tool that annually assesses the quality of policies and the performance of institutional frameworks in the 54 African countries. It measures the capacity of a country to support sustainable growth, poverty reduction, and the effective use of development assistance with a particular focus on the assessment of key elements that are within the country's control, rather than on outcome" (African Development Bank, 2017).

Similarly, the United Nations states that the usefulness of the indicators used to measure the rule of law is derived from their simplicity, but notes that indicators can remove complexity and context, and mask important differences. To avoid these problems, the United Nations uses multiple data sources, focused on countries, organises institutions into clusters, and measures performance from the perspective of stakeholders (United Nations Office of the High Commissioner for Human Rights, 2011). Albers (2007) has explained that the Good Governance Index (GGI) measures perceived level of governance through the subjective opinions of those who demand it, e.g., citizens and experts, while the Doing Business Index measures the attractiveness of countries to companies which invest around the globe. Both the GGI and Doing Business indexes group objective indicators into clusters, and measure the quality of laws and institutions from the 'demand' side, i.e., from the perspective of stakeholders. However, perspectives are inherently subjective, as has been discussed by Amanda Perry in her investigation of the factors which colour perceptions of legal rules, e.g., power distance. She noted that countries with small power distance, e.g., the United Kingdom, are characterised by rule-based systems. In countries with large power distance systems, e.g., Philippines, she has suggested that the legitimacy of rules is seen as irrelevant, as might triumphs over right (Perry, 2002). Through Perry's analysis, it is clear to see that rules are defined and interpreted by different users according to their subjective value systems and cul- 
tural contexts. This agrees with the argument made in Chapter 2 of this thesis, law is amenable to a variety of purposes and interpretations (See 2.6).

After decades of legal reforms and measurements of the quality of laws and institutions, there is yet to be definitive agreement on the substantive meanings or manifestations of legal rules and concepts captured by these indices. As such, the rules of western advanced countries remain as the aspirational benchmarks for other countries to imitate (Siems, 2011; Milhaupt, 2009).

However, despite the implementation of 'model' legal reforms over several decades, developing economies have yet to achieve comparable improvements in their economic standings. I would argue that the gap between legal transplantation and economic performance can be attributed to two factors, the first of which can be traced to the second and third limitations of NIE as given in this thesis, namely that it is difficult to define institutions, and that it is not clear whether institutions precede or follow development (See 5.1). There is an inherent difficulty and contradiction in the measurement of a concept which is not clearly defined. This ambiguity creates the problem of causation, which has yielded disagreement: in 2000, Amartya Sen undertook a review of the 'comprehensive approach' to development, and showed the causative connections between legal systems and economic evolution. He pointed to the rise of capitalist economic model to assert that "capitalism did not emerge until the evolution of law and order and the legal and practical acceptance of property rights had made an ownership-based economy feasible and operational" (Sen, 2000, p. 16). Following this line of thinking, indexes such as Doing Business seem to suggest that the improvement of legal rules and functions of institutions necessarily result in economic improvement, measured by attractiveness to certain types of investors. NIE scholars have consistently put forward evidence to show that the quality of laws and institutions directly affects economic performance. For example, in their paper 'Growth without Governance', Daniel Kauffman and Aart Kraay use econometric evaluations of 175 countries over a period of one year to argue that "per capita incomes and the quality of governance are strongly positively correlated across countries" (Kauffmann \& Kraay, 2002, p. 1). Similarly, Acemoglu \& Robinson, (2012); Acemoglu, et al., (2001); Djankov, et al., (2006); Rodrik, et al., (2004) have all presented evidence to show a connection between the quality of rules and institutions, and economic development. Secondly, the Law and Economics vision of private-sector led development creates a perspective in which the quality of laws is determined by the usefulness of laws and government institutions to investors and business. In the book 'Solomon's Knot: How Law Can End the Poverty of Nations', HansBernd Schäfer and Robert Cooter stated emphatically that the path to economic growth is through business ventures. It follows that the issues of law deemed necessary for development are those concerned with property rights, reduction of government corruption, enforcement of contracts, access to credit, etc. (Schäfer \& Cooter, 2011). Recall that Davis and Trebilcock (2008) criticised the investor-centric focused approach of NIEinspired legal reforms (See 1.4). 
Moreover, evidence linking the quality of laws to economic performance has been challenged on several grounds: the IMF has noted that developing countries, e.g., China, Botswana and Mauritius have made economic gains under institutional arrangements substantially different from those prescribed by IFIs (International Monetary Fund, 2003). Also, while there seems to be evidence linking clusters of institutional types to growth, specific features of institutions which cause improvements in economic performance have not been empirically determined (Fritz, et al., 2012; World Bank, 2012). Importantly, these indices have not provided a map as to how countries may acquire and embed the features prescribed as necessary for economic development. Thomas Carothers has pointed to the insufficiency of the intellectual and knowledge foundations of the rule of law assistance of IFIs. Carothers (2003) held up the economic performance of China as the largest recipient of Foreign Direct Investment globally as a counter-argument to show that weak rule of law (as defined by IFI indexes) was less important to investors than the prospect of profit. He argued that the rule of law approach suffers from a lack of knowledge at many levels of conceptualisation, operation and evaluation: "to start with, there is a surprising amount of uncertainty about the basic rationale for rule-of-law promotion. Aid agencies prescribe rule-of-law programs to cure a remarkably wide array of ailments in developing and post-communist countries, from corruption and surging crime to lagging foreign investment and growth" (Carothers, 2003, p. 10). Similarly, as stated in Section 1.4, Julian Du has argued that China achieved its impressive economic growth record in absence of adequate legal institutions; the country is rated below average on various measurements of rule of law, property rights protection, contracting institutions etc. (Du, 2011). It seems then that current indices which measure the quality of laws and institutions show correlation, rather than causation.

Criticising the econometric approach to the measurements of the quality of law, Helland \& Klick, (2011) have noted the profound impact and intellectual influence of the Legal Origins literature, which is the most cited paper in the economics discipline since its publication. They also note that subsequent studies, including those conducted by NIE scholars such as Acemoglu, et al., in 2001 on the Colonial Origins of Comparative Development follow the microeconomic evaluation model of Legal Origins. Thereafter, they criticise the econometric model on the basis that microeconomic tools are unsuitable, due to the nature of legal institutions. Indeed, they assert that the "fundamental problem is one of statistical identification" (Helland \& Klick, 2011, p. 100), by which they mean that it is not possible to account for all the factors and variables which lead to an outcome:

"That is, how can one isolate the causal effect of $x$ on $y$. If one knew everything that affected $y$, and had data for all of those variables, this would be a trivial problem to solve. In that context, a regression that included all of those variables would yield causal estimates that would be unbiased. Unfortunately, economic 
theory is not nearly so well developed that any researcher could possibly know all of the important variables affecting the outcome of interest if that outcome is even moderately complex. Further, even if theory or intuition did provide a welldeveloped guide, many of the important variables would be difficult to quantify or, at least, to get data that captured them. While proxies sometimes exist, they are never perfect" (Helland \& Klick, 2011, p. 109).

On the basis of this criticisms, Helland \& Klick, (2011) maintain that it is problematic to draw policy conclusions and recommendations about the institutions to be adopted by developing countries. On this premise, it is imperative to ask- how then should the quality and effectiveness of legal systems be measured?

\subsubsection{Evaluate Law Against Outcomes}

I would argue that law should be measured by whether it can lead economic systems to achieve good outcomes. This measurement would evaluate the outcomes, intended and unintended, of the stipulations of legal instruments, through an interrogation of the interpretation and behaviour of institutions. In its discussion on the evaluation of reforms, the Legal Vice Presidency of the World Bank recommended that evaluation of legal reform should first identify the economic activity that will be directly affected by the reform (Legal Vice Presidency, World Bank, 2003). In this regard, legal instruments introduced for the purpose of managing economic activities state clear objectives to be achieved and outcomes to be generated by institutions. Laws create mental constructs which guide thought systems, as well as the behaviour and functions of institutions. Previous chapters (See Chapters 3 and 4) discussed the ways by which the budgetary legislations in Nigeria and Rwanda guide the debt management functions of government institutions through tools and activities prescribed, e.g., debt sustainability analyses and medium-term expenditure analyses. It is difficult to prove causality, i.e., a link between legal instruments and economic outcomes, due to the multiplicity of elements (endogenous, exogenous, domestic, international, etc.) in economic processes. Nonetheless, it is possible to evaluate the effect of law on 1) Institutional Behaviour and Functions, 2) Dynamics of Interaction between Institutions, and 3) the Environment created by Institutions. Evaluations of the effect of law on these three elements allows:

a) Assessment of whether, and the extent to which legal frameworks and instruments are suitable for purpose;

b) Observe the interplay of law and institutions to identify points of synergy, conflict/contestation, and ineffectiveness; and

c) Identify opportunities for further reforms of laws and institutions

The review of legal reform (budgetary legislations) in Nigeria and Rwanda highlights the importance of the proper conceptualisation of laws as instruments of economic devel- 
opment. Current budgetary legislations in both countries emanated from the PRSP process which is guided by the IMF and the World Bank. Consequently, the provisions which govern public debt management reflect the agenda and concerns of the era, i.e., debt relief to reduce heavy debt burdens, and the introduction of binding measures to the prevent the accumulation of debt burdens. Thus, the Governance agenda of New Institutional Economics as adopted by IFIs is displayed in the structures and functions of national governments: debt management is limited to constraints on government borrowing, and monitoring of debt portfolios from a quantitative perspective. The casestudy points to the necessity of an outcome lens approach to legal reform and evaluation of laws. Legal instruments, which are introduced to underpin the achievement of economic objectives, will require the attribute of responsiveness. In this regard, periodic reviews and evaluations of the effect of laws, measured against outcomes in the behaviour and practices of government and other stakeholders is necessary. Also, the extent to which laws contribute to the achievement of stated goals should be considered. Findings can then be integrated into development planning, and reforms of legal/regulatory systems as necessary. The evaluation of the interaction of law and economies is imperative to ascertain the benefits and burdens created on stakeholders, the limitations of laws and institutions, and to close the gaps which limit the effectiveness of law as an instrument for economic development.

This approach follows that of Faure, et al., (2010), who propose that legal interventions in developing countries should be evaluated against outcomes. Discussing environmental regulation, they observed that failings in regulation are not caused by enforcement difficulties, and argued that "forms of regulation employed have not been designed for application within a developing country, and, more importantly, an individual country" (Faure, et al., 2010, p. 144). They go further to suggest 'indicators' to be used in the construction of efficient environment regulatory systems in developing countries:

a) Standards of Effectiveness Should be Determined by Whether A Given Legal Reform Achieves the Goals as Set Within the Country;

b) Do Not Dismiss Transplants, But Proceed Cautiously and Be Guided at All Times by Local Needs and Knowledge

c) In Terms of Precision of Formulations, Consider Rule-Based Regulation Rather Than Vague or Flexible Standards

d) Opt for (Environmental) Instruments That Take Account of Low Capacity as Well as Any Corruption Problems

e) Choose the Level of Governance at Which Administrative Capacity Is the Strongest and Most Independent

The indicators provided by Faure, et.al., (2010), present a subjective and contextual approach to the evaluation of the effectiveness of legal reforms, particularly as these occur in developing countries. These indicators speak to outcomes as the benchmark of 
effectiveness, and the tools by which institutional capacity can be measured. In this case-study of Nigeria and Rwanda, the outcome-based evaluation of the budgetary legislations to improve public debt management against outcomes, is necessarily premised on an inquiry, i.e., have the budgetary legislations led to the intended outcomes of debt relief, i.e., reduced debt portfolios, lower debt service payments, and the developmental use of debt finance? (See $2.4 ; 2.5$ )

The answer is that, to a limited extent, the budgetary legislations have contributed to the intended outcomes of legal reform for debt relief. The laws have improved government management of public debt, as they have fostered greater accountability, and established defined mechanisms for government borrowing (See 4.4; 4.6). However, both countries have amassed significant debt burdens, with the attendant increase in debt service payments due in the short and medium term (See 4.3, 4.4 and 4.6). On the use of debt finance, the Government of Rwanda accounts for sectoral deployment and project based deployment of borrowings (See 4.5.2). In Nigeria, while specific deployment of debt finance is not reported by the Government, it is known that between 2011 and 2016, the Government financed the entirety of its capital expenditure budget, and a portion of its recurrent expenditure through borrowings (See 4.2).

The juxtaposition of the budgetary legislations and the current public debt portfolios of Nigeria and Rwanda provokes further interrogation. Several questions arise:

- Developmental use of debt finance: how can developmental undertakings be given priority in government borrowing?

- How would 'developmental' use of debt finance be determined and enforced?

- Should the laws be extended further to require the Governments to justify the acquisition of more debt to Parliaments?

- Can the budgetary legislations specify borrowing limits on the basis of estimated government expenditure on national social services and debt repayments?

- Would these types of legislations impinge on executive government power and authority?

- Are laws in themselves sufficient instruments for debt management?

These questions are beyond the scope of this thesis, but emphasise the argument that evaluating or measuring the effect of law on economic outcomes is a complex, not simplistic endeavour, which may generate more questions than answers. As discussed in this thesis, laws operate in diverse and evolving contexts, which are shaped by a plurality of ideological, historical, political and institutional elements, as well as various stakeholders, and economic objectives.

Thus, I would observe that the evaluation of law against outcomes would be problematic when attempted on a global comparative basis, as done by the Doing Business and CPIA indexes, as it is not possible to determine a single set of outcomes for divergent countries and various issues. As a result, the outcome-based approach is necessarily subjective and concerned with contextual achievement of economic objectives. Addi- 
tionally, it addresses the challenges associated with transplantation of laws and legal systems. As Carothers (2003) notes, typical legal reforms or rule of law aid programs follow the approach of "diagnosing the shortcomings in selected institutions-that is, determining in what ways selected institutions do not resemble their counterparts in countries that donors believe embody successful rule of law-and then attempting to modify or reshape those institutions to fit the desired model" (Carothers, 2003, p. 9). Furthermore, an outcome based approach incorporates both objective and subjective measurements to evaluate effect of law on institutions, and by extension, the economy, as explored in the table below.

Table 22: Sample Framework for Outcome-Based Evaluation of Law

\begin{tabular}{|c|c|c|}
\hline Question & $\begin{array}{l}\text { Benchmark/Indicator per economic } \\
\text { objectives (Legislation and Economic } \\
\text { Plans) }\end{array}$ & Evaluation \\
\hline What is the objective? & $\begin{array}{l}\text { Debt relief and economic } \\
\text { development } \\
\text { - Increase government spending on } \\
\text { developmental issues } \\
\text { - Reduce proportion of national } \\
\text { resources spent on debt servicing } \\
\text { - Maintain debt records database } \\
\text { - Set and maintain limits on } \\
\text { government borrowing }\end{array}$ & $\begin{array}{l}\text { - Frequency: annually, triennially } \\
\text { - Evaluator: governments, international } \\
\text { agencies, civil society, media, academia } \\
\text { - Tools and resources: composition of } \\
\text { national budgets and debt portfolios }\end{array}$ \\
\hline $\begin{array}{l}\text { What are relevant legal } \\
\text { instruments/legal } \\
\text { underpinning? }\end{array}$ & $\begin{array}{l}\text { - Legal provision/stipulation } \\
\text { - What obligation is created on } \\
\text { institutions? } \\
\text { - How should these obligations to be } \\
\text { implemented per legislation? } \\
\text { - How are these obligations } \\
\text { implemented? }\end{array}$ & $\begin{array}{l}\text { - Frequency: based on obligations } \\
\text { created by legal instrument, as well as } \\
\text { annual reviews. } \\
\text { - Evaluator: civil society, governments, } \\
\text { international agencies, media, } \\
\text { academia } \\
\text { - Tools: legal instrument, reports of } \\
\text { government activities and spending, } \\
\text { economic performance reports from } \\
\text { various sources (national, multilateral } \\
\text { and regional institutions, etc.) }\end{array}$ \\
\hline $\begin{array}{l}\text { Enforcement/Implementation } \\
\text { of Law }\end{array}$ & $\begin{array}{l}\text { - What provisions are enforced? } \\
\text { (positive, prohibitive) } \\
\text { - What provisions are not enforced? } \\
\text { - sufficient? } \\
\text { - Is there a need for review of } \\
\text { provisions or obligations? }\end{array}$ & $\begin{array}{l}\text { - Frequency: based on obligations } \\
\text { created by legal instrument, as well as } \\
\text { periodic reviews. } \\
\text { - Evaluator: civil society, governments, } \\
\text { international agencies, media, } \\
\text { academia } \\
\text { - Tools: observation of institutional } \\
\text { practices through reviews of reports, } \\
\text { and perceptions of stakeholders }\end{array}$ \\
\hline
\end{tabular}




\begin{tabular}{|c|c|c|}
\hline Question & $\begin{array}{l}\text { Benchmark/Indicator per economic } \\
\text { objectives (Legislation and Economic } \\
\text { Plans) }\end{array}$ & Evaluation \\
\hline $\begin{array}{l}\text { Interplay of Law and } \\
\text { Institutions }\end{array}$ & $\begin{array}{l}\text { - Which institutions comply with } \\
\text { obligations? } \\
\text { - Which institutions do not comply } \\
\text { with obligations? } \\
\text { - What are the reasons for } \\
\text { compliance or non-compliance? } \\
\text { - Should obligations be reviewed, } \\
\text { reassigned or removed? } \\
\text { What interventions are necessary } \\
\text { to improve interaction of law and } \\
\text { institutions? }\end{array}$ & $\begin{array}{l}\text { - Frequency: based on obligations } \\
\text { created by legal instrument, as well as } \\
\text { periodic reviews. } \\
\text { - Evaluator: civil society, governments, } \\
\text { international agencies, media, } \\
\text { academia } \\
\text { - Tools: observation of institutional } \\
\text { practices through reviews of reports, } \\
\text { and perceptions of stakeholders }\end{array}$ \\
\hline Outcomes & $\begin{array}{l}\text { What progress has been made } \\
\text { towards the achievement of } \\
\text { economic objectives? }\end{array}$ & $\begin{array}{l}\text { - Frequency: annually, triennially } \\
\text { - Evaluator: governments, international } \\
\text { agencies, civil society, media, academia } \\
\text { - Tools and resources: composition of } \\
\text { national budgets, debt portfolios, } \\
\text { economic performance evaluations }\end{array}$ \\
\hline
\end{tabular}

Outcome based evaluations are not intended to be conducted primarily for ranking or comparisons of economies. Rather, the fundamental objective is to enhance the suitability and effectiveness of laws and institutions for the stated purposes of economic development. In this case, the benchmark is the objective as adopted by the country. For example, Nigeria and Rwanda both implemented PRSPs to improve their economies, but the tangible and specific measurements of these are unique to both countries. Rwanda sought to achieve lower-middle income status by 2020 and to maintain its debt at sustainable levels, measured by the NPV of debts-to-exports ratio of 150 per cent (See 3.4.1; Ministry of Finance and Economic Planning, 2002). Nigeria intended to increase spending in the social sectors, particularly health, education, water and infrastructure (Nigerian National Planning Commission, 2004).

In various countries, the same set of questions can guide the interrogation of the outcomes, or responses of law on institutions, as well as effects of legal instruments on economic development. The data required for this method of evaluation are available in the public domain, and the methodologies for analysis can be adopted by stakeholders, whether government, private sector, IFIs, civil society or academia. This approach is similar and complementary to that adopted by Doing Business and CPIA in that it groups elements into clusters. However, while benchmarks and conditionalities are not problematic in themselves, their use is limited when they do not speak to outcomes or results (Andrews, 2013; Riegner, 2016; Milhaupt, 2009; Siems, 2011). If development connotes improvement and progress (See 1.1), then it should be measured from the perspective of tangible outcomes and changes. Current tools of evaluation of law (Doing Business, CPIA, GGI) are rooted in NIE thinking which promotes the idea that institutions matter. In the same way, outcome evaluations require intellectual underpinning and direction, which is sourced from a combination of movements: these are firstly, the 
original Law and Development movement, which asserted that law is an instrument to drive economic development. Secondly, as the outcome-based approach takes its starting point the practices of institutions, vis a vis legal frameworks, the NIE school of thought which is centred on the importance of institutional quality for economic improvement provides it with ideological basis. However, this approach takes institutional practices not as the outcome, but as the starting point to probe further, and interrogate the suitability, relevance and effectiveness of legal instruments and frameworks. The outcome-based approach to evaluation may be of greater benefit and use to governments and domestic stakeholder groups, than IFIs which have designed proprietary tools in common use. Governments and national stakeholder groups are those which are primarily concerned with the achievement of economic objectives. Nonetheless, academia and international institutions may have an interest in the observation of the interplay between legal instruments, institutional behaviour and economic performance. The table below presents the similarities and differences of the outcomefocused approach and the current system of index-based evaluation.

Table 23: Comparative Table of Outcome-Based Evaluation and IFI Indexes

\begin{tabular}{|c|c|c|}
\hline Element & Outcome Analysis & Indexes \\
\hline Approach & $\begin{array}{l}\text { Observe and analyse effect of laws on institutions, and } \\
\text { outcomes in economy }\end{array}$ & $\begin{array}{l}\text { dMeasure quality of laws and } \\
\text { institutional arrangements }\end{array}$ \\
\hline Benchmark & $\begin{array}{l}\text { Determine and enhance suitability and effectiveness } \\
\text { of legal instruments and institutions for objectives of } \\
\text { economic development }\end{array}$ & $\begin{array}{l}\text { Global comparative evaluations of } \\
\text { best performing economies }\end{array}$ \\
\hline $\begin{array}{l}\text { Evaluation } \\
\text { methodology }\end{array}$ & $\begin{array}{l}\text { Factual observations of institutional practices, } \\
\text { perceptions of stakeholders, and observations of } \\
\text { economic performance }\end{array}$ & Perceptions of stakeholders \\
\hline Tools & $\begin{array}{l}\text { Questionnaires/surveys } \\
\text { References to economic data (e.g., debt portfolios) }\end{array}$ & $\begin{array}{l}\text { Questionnaires/surveys administered } \\
\text { by IFIs }\end{array}$ \\
\hline Ownership & $\begin{array}{l}\text { Independent evaluations conducted by governments, } \\
\text { IFIs, and other interest groups }\end{array}$ & International Finance Institutions \\
\hline
\end{tabular}

The outcome based approach is dependent on the clarity of economic objectives within countries. As noted above, it is difficult to measure concepts which are not expressly defined. In this regard, it is necessary that the development objectives and metrics are subject to clear definitions, interpretations and measurement. Legal reforms create changes in economies, and require changes in behaviour of institutions and other stakeholders. Thus, as law creates new obligations, thought systems and behavioural patterns, I argue that it is important for legal reforms to explicitly consider and define the institutional behaviours and objectives which are to be effected through legal instruments. As an example, I review the S41(1)(a) of the Fiscal Responsibility Act 2007 (Nigeria), which stipulates the purposes for which Governments in Nigeria may borrow:

"Government at all tiers shall only borrow for capital expenditure and human development, provided that, such borrowing shall be on concessional terms with 
low interest rate and with a reasonably long amortization period subject to the approval of the appropriate legislative body where necessary".

The majority of terms in this clause have definitive economic interpretations, including: capital expenditure, concessional terms, low interest rate, long amortization period, even as the term legislative body clearly refers to the National and State Parliaments. However, the term development can be contested, and may be subject to divergent interpretations or assessments. Thus, it would be useful for the legislation to avoid subjectivity surrounding definition of the term, and provide an interpretative guide. The questions below tackle some of the questions which arise from the obligation placed on the Nigerian Government by the Fiscal Responsibility Act 2007:

i. What is human development?

ii. What are the benchmarks by which human development is measured? Single or multiple dimensions? Numerical? Quantitative? Target-based?

iii. Who sets this benchmark? The executive government? Independent government agencies? Parliament? Multilateral agencies?

iv. How is this benchmark reached? Independently? Is there a consultative process?

v. Who applies these benchmarks? Are they published and located in the public domain? What capabilities are necessary to engage in assessment of government satisfaction of criteria established by benchmarks?

vi. When should benchmarks be applied and purpose measured: before, during or after debt acquisition?

vii. How is compliance with purpose enforced: is there a procedural means of verification? Approval systems? Obligation to publish purposive analysis in public domain?

viii. How are these functions (i-vi) allocated between stakeholders, i.e., executive governments, parliaments, citizenry, lenders and guarantors, beneficiary communities?

Thus, I argue that it is imperative that legal reforms are accompanied by careful consideration of obligations created, and definition of the terms, processes and responses by which legal instruments will be applied. Legal reforms for economic development should capture and define all relevant economic activities and processes which are guided or directed by laws. It may be necessary for legal instruments to provide definitions or refer to other instruments or institutions which will provide clarification, definition or measurement of concepts.

\subsubsection{Enhance Interplay of Law and Institutions}

The discussion of debt accumulation by the Governments of Nigeria and Rwanda (See Chapter 2), as well as SAPs implemented in both countries show that institutions can function without law. However, where law is introduced as the overarching framework, institutions are restricted by the interpretations of objectives, roles and functions pre- 
scribed by legal instruments. Thus, legal reforms should address contexts of implementation, and enable the achievement of economic objectives. To be relevant, suitable and effective, law introduced as an instrument of economic management should interact with, and enable institutions operating in its area of remit. The interplay of laws and institutions is a critical component in the effectiveness of law as an instrument for economic development. Thus, I reiterate the argument that legal reforms should be concerned with the utilisation of law for outcomes, rather than the approach which places law as a solution in itself.

In this regard, the role of institutions (organisations), is critical. Thus, I propose that the effectiveness of legal instruments can be enhanced using tools such as indexes which can support institutions towards the satisfaction of obligations created by legislation. Indexes are usually applied towards the measurement of the quality of law, and ranking of economies based on the types of laws adopted. However, I suggest that the methodology of indexes can be integrated into the application of legal instruments to facilitate the achievement of economic objectives. For example, a 'development' index can be used in conjunction with the FRA 2007 to ensure that Nigerian Governments satisfy the human development requirement for borrowing as discussed below:

\section{Sample 'Human Development' Borrowing Index: Categories}

a) Population segments and proportion of population to benefit from debt-financed undertaking?

b) How does undertaking lie within developmental goals and progress?

c) Developmental areas, e.g., health, education, sanitation, infrastructure, etc.?

d) New undertaking? Upgrade of existing facility/service? Repair of existing facility/service?

e) Justification for undertaking: what is the current state of the problem/opportunity? How is this justification verified?

f) Why debt finance? Alternative sources of finance, costs and terms?

g) Expected Outcomes?

a. Costs to national development and beneficiary groups if debt financed undertaking is not implemented?

b. Benefits of debt financed undertaking to national development and beneficiary groups?

c. Success and failure metrics?

h) Responsible/borrowing government?

i) Current and expected debt obligations, and credit history of borrowing government?

j) Monitoring and evaluation mechanisms for use of debt finance?

k) Partners? 
As with current indexes, governments and stakeholder groups can measure the extent to which their purpose of borrowing satisfies the requirements of the borrowing index. In addition, on a comparative level, such an observatory index can be used by academia and other stakeholder groups to provoke meaningful discussion on the use of debt finance in Africa. To illustrate, developmental use of debt finance in Africa can be monitored through an index-based diagnostic tool, adapted from the provisions which govern the purpose of borrowing in African countries. Firstly, this tool can identify those countries which explicitly direct debt finance towards developmental purposes. Secondly, it can attempt to articulate the meanings of development within borrower countries. Thirdly, as a borrowing index, it can track the purposes for which governments have borrowed over time, monitor borrowing trends, and categorise countries according to performance. Such an index used by IFIs, governments and other stakeholder groups would generate policy and intellectual discussion as to how to improve the utilisation of debt finance for development in Africa, and lead to more concretised definitions and indicators of development.

Furthermore, following evaluation of outcomes, (and the review of institutional behaviour), incorporation of institutional practices can narrow the gaps between legal frameworks and the contexts in which reforms will be implemented. For example, S45 of the FRA 2007 requires financial institutions to ensure that borrower governments have obtained approval for borrowing, and intend to use debt finance for capital expenditure. However, Nigerian financial institutions have adopted practices to reduce the risk of government default on loans (See 4.3.2). To avoid non-repayment of loans, the banks make lending decisions and set borrowing limits for governments on the basis of minimum balances maintained in government accounts (Okosodo, 2017). On occasion, disparities may be observed between the stipulations of legal instruments and institutional practices. A thorough mapping of existing practices can identify the functions, capacities and effects of institutions, whereupon beneficial practices can be integrated into, codified and regulated by legal instruments.

\subsection{Summary}

Through the proposition above, I suggest that standardised legal frameworks can be adapted to address the developmental needs, contexts and institutional frameworks of divergent contexts. Also, I would argue that some of the weaknesses of NIE-influenced legal interventions can be overcome by the methodologies of the outcome-focused evaluation approach. This approach is an attempt to address the gaps between legal reforms and economic outcomes. The interplay of laws, institutions and economic development is dynamic, evolutionary, subjective to context, and important to understand. Economic and legal interventions prescribed by international finance institutions for developing economies are often criticised for their standardised and prescriptive 


\section{Chapter 5}

approaches which do not necessarily consider the specific elements of the contexts in questions. This dissertation took its point of departure from the work of scholars in law and development, and NIE who have argued that laws and institutions is important for economic development (See Chapter 1; Acemoglu, et al., 2001; Acemoglu \& Robinson, 2012; Kaufmann, et al., 1999; Kauffmann \& Kraay, 2002; North, 1995, Rodrik, et al., 2004; Sen, 2000). Through the investigation of Nigeria and Rwanda, this dissertation has argued that legal reforms have contributed to improvements in government management of public debt. However, these reforms can be described as limited, as they have not changed borrowing practices of the governments of both countries. 
Chapter

Conclusion 

How can law be better used as an instrument for the economic development of the African continent? This is the question which inspired and guided the investigation of this thesis. Nigeria and Rwanda were selected for the comparability and contrast in their political and institutional arrangements, as well as in economic performance. The thesis considered the relationship between law and economic development, as shaped by the Governments of Nigeria and Rwanda, over five decades. Also, the study considered the policies, interventions and operations of the World Bank and IMF, particularly the influence these institutions wield in shaping development discourse and practice, as well as their influence upon the economies and developmental trajectories of Nigeria and Rwanda between the 1980s and 2000s.

The effectiveness of law for economic development was interrogated through an evaluation of the outcomes from legal reforms undertaken to improve public debt management in Nigeria and Rwanda. Through the investigation of the evolution of debt portfolios of Nigeria and Rwanda between 2005 and 2015, the study concluded that budgetary legislations introduced discipline and accounting into systems for public debt management, but have yet to contribute to the sustainability of debt portfolios, or direct governments to use debt for development in measurable ways. The lessons from the case-study undertaken in the preceding chapters are applicable for other countries on the African continent, especially those in similar circumstances, i.e., struggling with accumulating debt and working to engineer economic improvements.

Institutional thought has pointed to the absence, functions or ineffectiveness of laws and institutions to explain differences in developmental outcomes (North, 1995; Acemoglu \& Robinson, 2012; Acemoglu, et al., 2001; De Soto, 1989). The central argument of these is that better laws and institutions would lead to better outcomes for development. Similarly, Legal Origins theorists rely upon legal antecedents and culture to explain economic performance (La Porta, et al., 2008). In development practice, multilateral institutions have integrated the 'institutions' thinking and tools into policy and operations, which has yielded econometric evaluations of legal systems and their functionalities. Indexes, such as Doing Business and the Country Policy and Institutional Assessment (CPIA) evaluate the quality of laws, and the operations of legal systems in diverse areas, from debt management to immigration.

However, legal reforms based on this thinking have been criticized for being vague, as the concept of institutions remains undefined (Chang, 2007). Nonetheless, economists have included laws in the contemporary understanding of institutions (North, 1995). Also, it is not yet clear what makes institutions good, or bad. Yet improvements to institutions are regularly prescribed and implemented, especially in developing countries. These improvements are largely modelled on the legal systems of more advanced economies (Mihaupt, 2009), and the interventions have yet to yield results as intended (Andrews, 2013; See Chapters 3 and 4). Following the heavy accumulation of debt in the 1970s, and the economic contractions and debt crisis of the early 1980s, the Governments of Nigeria and Rwanda implemented Structural Adjustment Programs to rectify 
structural weaknesses of their economies. By the 1990s, both countries had acquired unsustainable debt burdens, which were reduced through debt relief offered by creditors in 2005. Criticisms of IFI interventions in borrower economies led to policy reforms within the World Bank and IMF, and the shift to country-led implementation of reforms towards the end of the 1990s. Also, the 1990s brought a global, concerted campaign for debt relief and the rise of the global 'development' agenda. Riding on the wave created by the debt relief and development movements, the Governments of Nigeria and Rwanda argued that debt burdens and debt repayments diverted necessary resources for development. Debt relief would thus enable increased spending on developmental needs. Debt relief was contingent on the satisfactory implementation of economic and institutional reforms captured in the Poverty Reduction and Strategy Papers (PRSPs) of both countries, as approved by the International Monetary Fund.

A critical component of reforms for debt relief was the enactment of budgetary legislations to regulate government management of public debt. Debt management provisions of budgetary laws in both countries are similar; the Fiscal Responsibility Act 2007 in Nigeria and the Organic Budget Laws 2006 and 2013 in Rwanda both stipulate the authority of governments to borrow, purposes for which governments may borrow, debt limits, and debt management systems. These laws were introduced for the purpose of economic development, particularly, to prevent the build-up of debt portfolios. Both countries, through the PRSPs (Nigeria-2003, Rwanda-2002), expressed their immediate and medium-term objectives of economic development.

The evaluation conducted in this thesis discussed the instrumentalism of law for economic development: the budgetary laws in Nigeria and Rwanda have become the frameworks and constructs through which the Governments of both countries manage public borrowing. These laws direct the functions of government institutions, manage competing interests, and serve as tools of economic management. However, the thesis also highlighted the limitations of current systems for the measurement of the quality of laws and institutions: in Nigeria and Rwanda, there are well established systems for the accounting and reporting of government debt. On the CPIA index of the World Bank, both Nigeria and Rwanda have performed better than average: in 2016, Nigeria scored 4.5 out of 6 , and Rwanda scored 4.0. However, these scores can be challenged upon closer scrutiny, as the Nigerian Government has yet to set the limits of government borrowing, despite the obligation created by legislation. Also, while external borrowing is constrained, National and Sub-National Governments can borrow in the domestic market without restriction. In contrast, Government borrowing in Rwanda is centralised, and debt limits are set triennially. Additionally, in Rwanda there has been better accounting of the specific projects which have been prosecuted by debt finance. However, the bulk of Nigeria's borrowing has served to finance recurrent expenditure.

Specifically, debt relief was directed towards the reduction of external debt to sustainable levels. However, budgetary legislations have not prevented the build-up of debt in both countries. Nigeria and Rwanda have acquired significant debt obligations, 
which have led to high debt service payments. High levels of debt service return both countries to the economic situation before debt relief, where large amounts of financial resources were transferred to creditors, rather than being utilised within the country. In light of this, I argued that the index-based methodology for the evaluation of laws and institutions is insufficient, as these do not qualitatively and adequately evaluate the usefulness, suitability or relevance of legal instruments and institutional functions. Indexes, in effect, measure the extent to which legal systems have adopted the legal systems of advanced economies, typically those of western countries. It is difficult to rationalise that the legal constructs of a developed economy would be ideal and supportive for the aspirations and contexts of developing economies, without proper contextual adaptation. Based on this argument, I proposed that the effectiveness of legal systems should be measured against outcomes, which are the expressed economic objectives of the country.

Measuring legal systems against outcomes has been criticised on the basis that it is difficult to prove causation, i.e., direct effect of law on economic performance. However, I argued that the problem with causation is linked to the problem of definition; if the objectives of institutions and laws are not expressly defined, then it would be difficult to show causation. Despite comparable legal reforms, the debt portfolios of Nigeria and Rwanda remain large, and there is the inherent risk of the build-up of unsustainable debt. Thus, I proposed an approach to observe the interaction of laws and institutions, particularly to evaluate institutional interpretation of and compliance with stipulations of legislation, and how these interactions enable the achievement of stated economic objectives. Through this approach, I argued that the gaps or weaknesses in laws and institutions can be more easily identified and remedied. Also, I argued that using this approach would render standard-form legal reforms more suitable and relevant to divergent contexts.

Measuring outcomes may not necessarily be of primary interest to International Finance Institutions, but should be of importance to governments. The outcome-focused approach is not undertaken for comparison with other economies, but to enhance the instrumentalism of law for national economic development. I noted that the outcome approach is dependent on the clarity of the economic objective stated, and the capacity of institutions to function towards the achievement of economic objectives. As such, I considered the possibility of the utilisation of indexes in the application of law, to support government institutions in the prosecution of legal obligations, and not only in the measurement of laws.

In summary, this thesis took its point of departure from the work of scholars in Law and Development, and Law and Economics, which have asserted that law is a necessary tool for economic development. Through the investigation and analysis, and the evidence of the case-studies, I have argued that law is an important tool for improving economies. In the context of debt relief, legal reforms have improved government management of debt portfolios. Nonetheless, it remains necessary to enhance the ef- 
fectiveness of legal instruments, as well as the interplay of laws and institutions, in order that laws direct institutions towards the achievement of developmental objectives.

\subsection{Revisiting the Research Questions}

This thesis was guided by three research questions, which are reviewed in this section:

\subsubsection{Question 1: Why Did the Governments of Nigeria and Rwanda Seek and Obtain Debt Relief in 2005?}

Nigeria and Rwanda sought debt relief, firstly, to alleviate huge debt burdens, and secondly, to rectify the institutional weaknesses which had allowed the accumulation of public debt owed to international creditors. The Governments of both countries argued that repayments diverted resources from development spending and thus, inhibited development.

The Governments of both countries acquired loans during the economic boom period of the 1970s, i.e., the period in which the prices of commodities they sold were high on the international market. During this time, creditors (IFIs, Governments and Private Financial Institutions) provided credit to developing countries, including Nigeria and Rwanda, on terms which often included variable interest rates and compound interest (See 2.2). The 1970s also witnessed the increase of government participation in African economies. As Okonjo-Iweala (2012) notes, African Governments pursued the economic model of Import Substitution Industrialisation which required heavy spending in all sectors of national economies. Nellis (2005) corroborates this position in his explanation of the rise of State Owned Enterprises in Africa, as he states that these government owned enterprises accounted for up to an average of 17 per cent of national GDPs. During this time, African Governments obtained the greater part of their revenue from the sale of commodities on the international market. The economic model and associated vulnerabilities to external economic shocks were discussed in the 1980 Lagos Plan of Action of the Organisation for African Unity. This Plan sought to reduce the overdependence of African Governments on the export of basic raw materials and minerals (Organisation of African Unity, 1980).

The sale of crude oil formed the principal source of revenue for the Nigerian Government, as the sale of tea and coffee generated the greater share of revenue for the Government of Rwanda (See 2.2.1 and 2.2.2). By the 1980s, the prices of crude oil, tea and coffee had plummeted sharply, which resulted in reduced revenue for the Governments of Nigeria and Rwanda. It followed that both countries were unable to service debt obligations, which led to increased debt acquisitions, and frequent debt reschedulings. To resolve the debt crisis, IFIs provided technical and financial assistance to borrower countries. A central component of assistance was the Structural Adjustment 
Program (SAP), which sought to reduce the role of governments in economies, place the private sector as the lead agent of economic development, and restructure national economic systems towards efficiency (See 2.2.1 and 2.2.2).

SAPs in Nigeria and Rwanda were criticised for their prescriptive and intrusive features, particularly privatisation and liberalisation which reduced government participation in national economies (See 2.3; Stiglitz, 2008). Similar measures were implemented in both countries, leading to economic contractions, social dislocations and increased poverty. In Rwanda, it has been argued that the SAP was a significant cause of the war and genocide of the 1990s - the IMF and World Bank sanctioned government spending on the military, but constrained state spending on education and social subsidies (Chossudovsky, 1995; Toussaint, 2004; See 2.3 and 2.4).

By the 1990s, debt burdens had escalated to the point that debt repayments and obligations to creditors exceeded domestic spending on social services in borrower countries. The global Jubilee 2000 campaign consolidated the arguments put forward for debt relief by the scholarly community, activist groups and African Governments (See 2.4.1). These arguments can be organised into three categories:

1. Odious Debt: this is based on the legal principle that debt can be repudiated when obtained in the name of a borrower, but without their consent (Kremer and Seema, 2002). In this regard, governments had borrowed and deployed debt finance without the consent of their citizens. Also, the debt relief campaign argued that debt relief was cheap and would not adversely affect the economies of creditor countries (Krugman, 1990). Furthermore, debt repayments prevented the economic and social development of borrower countries (Watkins, 1994). Thomas Sankara, then President of Burkina Faso stated at a 1987 conference of the OAU that "debt cannot be repaid, first because if we don't repay, lenders will not die. That is for sure. But if we repay, we are going to die" (Sankara, 1987).

2. Joint Responsibility of Borrowers and Creditors: the debt relief campaign argued that creditors provided debt finance without proper due diligence, and thus accepted the implicit risk that debts would not be repaid (See 2.4.4; International Monetary Fund, 1999). Similarly, the terms on which debt was rescheduled, poor advice by IFIs, and protectionist economic policies of industrialised countries served to inhibit the economic recovery of borrower countries (Forum on Debt and Development, 1992).

3. Development, not Debt: debt repayments often exceeded spending on developmental needs. Indeed, it was argued that borrower countries were forced to choose between spending on infrastructure and social services, or the satisfaction of debt obligations (Greenhill, 2002; See 2.5). The Millennium Development Goals, adopted by 189 countries at the United Nations General Assembly further emphasised the global development agenda, and served as a reference point to measure and track developmental progress (United Nations Millennium Project, 2006). The debt relief campaign argued that borrower countries would use the savings gained from debt relief to achieve the global development goals agreed to at the United Nations. 
In response to the campaign, IFIs created structured avenues for indebted countries to reduce their debt burdens. While debt relief measures were available from the late 1980s (See 2.4.4.), these were essentially debt reschedulings to allow later repayments. In 1996, the Heavily Indebted Poor Countries (HIPC) Initiative, and its successor Enhanced HIPC (1999) were introduced by the World Bank and IMF as a channel for borrower countries to discard debt burdens. The HIPC process required that beneficiary countries prepare national development plans in the form of Poverty Reduction Strategy Papers (PRSPS), which would correct the structural and institutional weaknesses which allowed the build-up of debt. Under the Enhanced HIPC, the extent of debt relief was determined at the commencement of the HIPC program and acceptance of the PRSP by IFIs, with completion date determined by the policy or reform implementation performance of borrowers.

The bulk of Nigeria's debt was obtained from commercial creditors, particularly the Paris Club. Also, Nigeria did not qualify as an IDA-only country due to its economic ranking. Nonetheless, it modelled its debt relief application on the processes stipulated by the HIPC: in 2003, the Government of Nigeria submitted a PRSP which expressed its 4 year development strategy, which incorporated economic, institutional and legal reforms. In 2005, halfway through implementation, Nigeria obtained debt relief worth US\$18billion which represented 60 per cent of its total debt owed to the Paris Club (US\$30billion).

The greater share of Rwanda's debt was owed to IFIs, particularly the World Bank and the IMF. In 2002, the country submitted a PRSP, in the form of a 10year development strategy which articulated its economic objectives, as well as planned economic, institutional and legal reforms. In 2005, the country obtained debt relief worth US\$1.4billion.

Nigeria and Rwanda, despite their marked differences (historical, geographic, and institutional), shared similar experiences of heavy acquisition of external debt between the 1970s and mid-2000s, the build-up of unsustainable debt burdens, and debt relief from creditors obtained in 2005. In both countries, Governments had attempted, through direct intervention in their economies, to influence economic performance in the 1970s, which resulted in SAPs administered by the World Bank and IMF in the 1980s. Thereafter, Governments adopted PRSPs and the associated reform agenda. In Chapter 2 of this thesis, following the discussion on the build-up of debt burdens, I made the following observations:

1. Firstly, the experiences of both countries clearly emphasise the centrality of law to economic development. At a simplistic level, debt finance was obtained, and debt obligations created by the contractual agreements which were made between creditors, and Nigeria and Rwanda. These agreements were governed by international law, and upheld by international institutions. In similar vein, the interventions of international institutions, particularly the World Bank and the International Monetary Fund were supported by the Articles of Agreement which establish both institutions. 
Similarly, in both Nigeria and Rwanda, legal frameworks served as tools of economic management by both military dictatorships and civilian administrations. To illustrate, in Nigeria, to obtain loans from international creditors, the military dictatorships of General Obasanjo and General Babangida both repealed substantive legislation which stipulated the national debt ceiling. In Rwanda, the government was constrained, to some degree, by the terms of the IMF SAP which controlled the use of government finance.

2. Secondly, the relationship between law and economic development is shaped by the vision of development, and model of governance operated by countries. Specific political-economic-social contexts determine the nature of interaction between laws, institutions and economic systems. The perception and deployments of laws and institutions are dependent on the fundamental ideology of the governance system. To illustrate, in Rwanda, the government was able to provide the military with resources during a SAP which contracted economic resources and negatively impacted upon social conditions. Legal instruments, e.g., policies, legislations or regulations reflect and underpin the vision, agenda, objectives and assumptions of governments. The powers and capacities of institutions which supervise and implement the vision of governments, are to a significant degree determined by the ideals and priorities of the governance system.

3. Thirdly, the effectiveness of laws is dependent on the existence of strong and independent institutions for enforcement. While it is accepted that a plurality of factors contributed to the economic problems of the 1970s and 1980s, it is clear that governance systems were instrumental to the rapid economic decline suffered by both countries. To illustrate, IFIs deployed considerable political, intellectual and economic resources towards the enforcement of contractual agreements. It followed that the Governments of Nigeria and Rwanda were held accountable and liable for financial obligations accrued under international law. Conversely, at national level, state and social institutions did not possess the requisite strength or independence to judiciously utilise debt finance, manage the developmental process, or hold governments to account. While the terms of SAPs implemented by the World Bank and IMF attempted to control the use of funds obtained from creditors, the mechanisms of the domestic legal systems were not sufficiently robust to adequately govern the disbursement of funds. Thus, the debt problems of Nigeria and Rwanda highlight the critical importance of well-functioning legal systems and supporting institutions for economic management.

4. Fourthly, while it is necessary to have laws and legal instruments to underpin the institutions which function for economic development, the political economy in which these institutions function is of equal importance. Political, economic, social, and cultural factors must be accounted for in the design or reform of institutions. These factors form the realities and the environment in which institutions will function. As such it is important not to rely upon assumptions, but to properly interro- 
gate the dynamics of the environment to identify challenges and opportunities which can determine the functions and operations of institutions.

Furthermore, I would argue that the experiences of Nigeria and Rwanda highlight the influence of the World Bank and IMF in international development policy and practice, as well as the difficulties of prosecuting developmental objectives in varying contexts; SAPs were criticised for their prescriptive, intrusive and uniform features, as well as their emphasis on macroeconomic performance (Stiglitz, 2008). The PRSPs transferred the burden of strategy development and implementation to countries, but have been similarly criticised for increasing surveillance and control of countries (Harrison, 2004). The influence of IFIs is undeniable: these institutions set the terms and standards by which 'good' or 'bad' policy is determined (Riegner, 2016). In the context of debt relief, the World Bank and IMF approved or denied requests for debt relief to borrower countries, and influenced the policies of other creditors. To illustrate, the Paris Club provided relief to debtors on the condition that an IMF SAP was implemented (See 2.4.4). As stated by Oxfam (2003), "the Fund's view of what defines the macroeconomic stability of a country is the authoritative one for all development partners. Given this, the Fund could and should be playing a dynamic, proactive role in establishing the financing conditions for achieving the Millennium Development Goals".

Nonetheless, the tools and approaches prescribed by the World Bank and IMF do support the diagnosis, analysis and forecasting of developmental challenges and solutions within countries, as will be presented in the following section which discusses the second research question through an examination of legal reforms for public debt management in Nigeria and Rwanda.

\subsubsection{In What Ways Did the Governments of Nigeria and Rwanda Deploy Laws and Institutions as Instruments of Debt Relief?}

Through the PRSPS, Nigeria and Rwanda embraced wide-ranging reforms intended to correct structural and institutional weaknesses. The PRSPs of both countries explicitly referred to legal reforms, especially budgetary laws (See 3.3 and 3.4). Chapters 3 and 4 discussed the budgetary legislations introduced to manage public finance, particularly public debt, in both countries. In Chapter 3, the benchmarking of these legislations was referred to as the fiscal rules found in some industrialised countries, e.g., the European Union. Budgetary legislations in Nigeria and Rwanda combine procedural and numerical rules to regulate government acquisition and management of public debt.

The PRSPs of both countries spoke to the necessity of debt relief to release resources for national development. Thus, the budgetary laws of these countries introduced systems for economic planning and government accountability. Importantly, the budgetary laws in Nigeria and Rwanda further present the dynamics of interaction between laws and institutions; these laws created new institutions to perform debt man- 
agement functions, even as they changed the functions of existing institutions, and regulated the relationship between various institutions. Also, it should be noted that while the laws emanated from the PRSP process, it is the National Parliaments of both countries that were ultimately responsible for drafting and enactment of the laws. Through the investigation of Nigeria and Rwanda, it is possible to observe the manifestations and dynamics of laws deployed for the express purpose of public debt management. Laws and legal frameworks function as mental constructs, even as they manage relationships and competing interests:

\section{a) Law as a Mental Construct}

The case-study presents law as both the creation and reflection of ideologies, beliefs and thought systems. As mental constructs, these laws articulate the assumptions and objectives of governments and IFIs that birthed legislations through the PRSPs. For example, the emphasis on public debt management reflects the intention of IFIs and governments to avoid the build-up of unsustainable debt portfolios: the provisions concerning public debt management reflect the concern of the era, which was to prevent a repeat of high external debt burdens, and the creation of mechanisms to ensure that debt acquisition is regulated, controlled and monitored by the government.

Similarly, the deployment of laws assumes well-functioning governance systems. In Nigeria and Rwanda, Executive Arms of Government must request approval of Parliaments to borrow. In this way, Legislative Arms of Government are placed as the final and higher authority for government borrowing. Thus, should the Nigerian Government acquire external debt without the approval of the National Assembly, the act of borrowing would be ultra vires, and illegal. Similarly, the FRA 2007 is enacted on the assumption that Government will repay its debts. Thus, the Act does not envisage circumstances of breach, and does not prescribe punitive measures or remedies. However, considering that at the time of enactment, the country had just benefitted from debt relief, which became necessary after years of non-payment of debt obligations, the omission of provisions to counteract non-payment of debt service seems somewhat optimistic. Also, in 2007, democracy in Nigeria was less than a decade in implementation, with the relationships between Legislative and Executive Arms of Government still in the early stage of evolution. Furthermore, the budgetary legislations assume that governments will make correct decisions for economic development. In Nigeria, external debt is to be utilised for capital projects which speak to human development. This approach is evident also in Rwanda, where the Government may borrow for general budgetary purposes. The utilisation, accounting or effective use of debt finance is not considered in the legislation.

In addition, mental constructs influence the behaviour of Institutions. The mental construct for public debt management in Nigeria and Rwanda is concerned with debt portfolio management, not necessarily debt for development. This construct shapes the institutional systems responsible for debt management, and economic outcomes: Gov- 
ernments are not required to account for performance on previous utilisation of debt, or justify the choice of debt finance over other types of finance, e.g., aid or taxation revenue for particular undertakings. Consider Nigeria, where borrowing practices of Governments have been shaped by the provisions of the FRA 2007: external borrowing of State Governments is restrained when compared to domestic debt portfolios. Per the FRA 2007, debt service amounts are deducted from revenue allocations due to State Governments. The provision of the FRA 2007 which requires National Assembly approval for external borrowing, as well as the practical consequence of reductions in revenue has contributed to discipline in the acquisition of external debt. On the other hand, the ability of State Governments to borrow in the domestic market is unregulated. As such, the Debt Management Office is confined to tracking government borrowing and the maintenance of a domestic debt database. As a result, domestic debt profiles exceed external debt obligations (See 4.2). In the case of Rwanda, the Law on State Finances and Property 2013 does not place restrictions on the purposes for which the Government of Rwanda may borrow (See 4.5). While this unfettered approach may be reflective of the developmental needs of the country, as well as its expectations of success, there is the attendant risk of government dependency on debt finance: if there are no restrictions, whether of duration or purpose, what then is the incentive for the government to reduce the incidence of borrowing?

\section{b) Law as a Relationship Manager}

The powers and functions allocated to the Ministers of Finance, and the centralisation of debt management functions reflect the macroeconomic approach and the lens of the World Bank and IMF to economic development. These laws provide a mandate, or terms of reference for the institutions of government responsible for enforcement and implementation: debt management functions, e.g., debt monitoring, debt sustainability analyses, approvals for borrowing, etc., are allocated between arms of government. These institutions look at legal instruments to define their authorities, powers and functions. Laws, in this regard, provide job descriptions and performance management mechanisms for governments. The constraints, powers and functions stipulated by budgetary legislations lead to practical outcomes: in both Nigeria and Rwanda, the Minister responsible for finance is authorised to acquire debt for purposes specified in the relevant provisions of the legal instrument. By implication, a request or an attempt by other Government Ministers or Agencies to borrow is rendered prima facie illegal. It follows that the Ministers of Finance, in both countries, are given additional levels of authority and power over other ministries and departments. In this way, law not only guides government behaviour, it shapes the political economy within government, and dynamics of relationships in its areas of remit.

Also, the legal and institutional frameworks in both countries exclude other stakeholders from the systems for the management of public debt. Public debt management functions, allocated between government institutions, do not engage communities, 
financial institutions, civil society or other interest groups. Executive Arms of Government are subject only to Parliaments which establish compliance with purpose of borrowing stipulations by reference to the relevant provisions of budgetary legislation. Similarly, debt monitoring is domiciled within the Ministries of Finance, and does not incorporate perspectives on the allocation or utilisation of debt finance, whether from financial institutions, sectoral stakeholders or communities.

\section{c) Law as a Manager of Competing Interests.}

The examination of legal reforms in Nigeria and Rwanda reveals the function of laws in managing opposing interests of stakeholders, over issues of common concern. Laws can bring coherence to multiplicity of interests in economic development, and manage conflicting interests through stipulations of benchmarks, standards and procedures. The table below outlines the mechanisms of the budgetary legislations and how these address the divergent interests of parties in public debt management.

Table 24: Law as a Manager of Competing Interests

\begin{tabular}{lll}
\hline Stakeholder & Interest & Mechanism \\
\hline 1. Citizenry & - Prevent unnecessary acquisition of & 1. Provisions governing purpose of debt \\
& debt & acquisition: (S41((1)(a) FRA 2007 and S51 \\
& - Effective and impact-oriented use of & Law on State Finances and Property 2013 \\
& debt finance & 2. Provisions which supervise debt \\
& - Cheap and favourable terms of debt & acquisition, e.g., S41(1) (c) FRA 2007 \\
& acquisition & 3. Provisions which require borrower \\
& - Participation in decision making & governments to obtain Parliamentary \\
& processes for debt acquisition and & Approval for external debt acquisition: \\
& utilisation & S41(1)(a) FRA 2007 \\
2. Lenders/Guarantors: & - Repayment of debt sums & 1. Provisions governing debt portfolio \\
(Financial Institutions, & Provision of debt finance to & management: S44(5) FRA 2007 and \\
Multilateral Agencies) & governments on a recurrent basis & Articles 53 and 56 Law on State Finances \\
& - Prevent unsustainable debt build-up & and Property 2013 \\
& - Effective management of debt & 2. Provisions stipulating sustainable debt \\
& portfolios & levels: S41(1)(c) FRA 2007 \\
& - Alternative source of revenue & 1 Provisions governing Authority to Borrow: \\
& - Easy access to credit & S41(1)(a) FRA 2007 and Article 50 Law on \\
- Good terms/cheap credit & State Finances and Property 2013 \\
- Ensure government compliance with & 1. Provisions which require borrower \\
(Executive) & procedural and substantive rules & governments to obtain Parliamentary \\
& & Approval for borrowing: S41(1)(a) FRA \\
4. Parliaments & 2007 and Article 52 Law on State \\
& & Finances and Property 2013 \\
\hline
\end{tabular}

Thus, Legal instruments serve to balance interests, manage expectations, guide interactions of interest groups towards achievement of a common objective. In Chapter 3, I presented some of the benefits of budgetary legislation in Nigeria and Rwanda:

1. Legal reforms, specifically legislations were introduced to ensure the achievement of macroeconomic stability. These legislations are similar to and replicate rules which 
exist in other political and economic systems, both western and emerging economies (see 3.2). Legal instruments to guide and regulate government management of state revenue and expenditure, i.e., budgetary legislation was enacted in both countries: the Fiscal Responsibility Act 2007 in Nigeria and the Organic Finance Laws (2006 and 2013) in Rwanda. The provisions of these laws are extensive, as they stipulate the roles, functions and operations of government and its institutions. The laws also serve as tools to guide the behaviour of government in the performance of its functions and obligations: processes, timelines and standards for economic management are prescribed.

2. For the purpose of debt management, the provisions of the laws clearly stipulate the importance of prudence. Mechanisms are established to ensure that powers and authority to acquire debt are restricted to specific arms of government. In the case of external debt, the approval of national parliaments is required prior to the acquisition of debt obligations. Furthermore, the justifications and reasons for which debt can be acquired are provided: for example, in Nigeria, borrower governments are required to present undertakings which directly benefit the Nigerian population. In Rwanda, the government is allowed to borrow for the purposes of economic improvement, as qualified under the Budget Laws.

3. Importantly, budgetary legislations demand that governments undertake economic and technical analyses to manage the economy. Both countries adopted the medium-term expenditure framework, through which 3year forward planning is undertaken, as well as annual calculations/reviews of revenue and expenditure. Debt management is given as a central responsibility of government, assigned to the Ministers of Finance. While the definitions of debt sustainability are subjective, the budgetary legislations in both countries speak to sustainability, which can be interpreted as an attempt to avoid situations of unmanageable debt, as experienced in the 1980s and 1990s. Also, these legislations empower government institutions to undertake supervisory functions to ensure compliance with legal obligations concerning debt management.

These benefits notwithstanding, in the decade since debt relief was obtained in 2005, the debt portfolios of Nigeria and Rwanda have risen steadily. Furthermore, the main argument for debt relief was that governments would have increased resources to spend within national economies, particularly for national development (See 2.5). The next section discusses the debt portfolios of Nigeria and Rwanda, and examines the extent to which the Governments of both countries have achieved the objectives of debt relief. 


\subsubsection{To What Extent, Have Legal Reforms Contributed to the Achievement of the Objectives of Debt Relief?}

In their pursuit of debt relief, the Governments of Nigeria and Rwanda argued that debt repayments inhibited government investment in national development. In 2005, creditors cancelled significant proportions of debt obligations owed by both countries. By implication, debt relief was intended to herald increases in developmental spending and improvements in social conditions. However, as discussed in Chapter 4 of this thesis, the debt obligations of Nigeria and Rwanda have increased steadily since 2005, thereby creating the risk of the build-up of unsustainable debt portfolios. Naturally, debt repayments have risen, which increases the proportion of financial resources transferred away from both countries (See 4.2; 4.3; 4.5.3).

National and Sub-National Governments in Nigeria are authorised to, and have borrowed extensively, from a variety of sources. These loans are yet to be linked empirically to the prosecution of capital and infrastructure projects. In mid-2017, several Nigerian economists advised the Nigerian Government against further borrowing, and emphasised the dangers of the high cost of debt repayments to the country. Professor Sherrifdeen Tella said "it is not healthy to continue to increase our debts. In fact, the growth in the last two years has been quite alarming, and so there is a need for us to slow down on it. It is not the debt itself that is important, but the interest rates that you pay on such debt and the usage of the debt" (Amaefule \& Asu, 2017). Corroborating this argument, Dr. Mike Omotosho argued that "borrowing in itself is not the main problem but what we spent the money on. In the last two years, I doubt if we have spent up to N2.5 trillion on infrastructure and other key policies that can help the economy and the people" (ibid). Dr Omotosho went further to note that 40 per cent of Nigeria's 2016 budget of N4.2trillion went to debt servicing (ibid). Similarly, Mr. Bismarck Rewane, a Nigerian economist and public affairs commentator noted that "we need to move away from debts for recurrent expenditure to debts for capital expenditure, which is projectsspecific. The debt level itself is not dangerous, but the debt service level-the debt burden is very high. We are using 66 per cent of our independent revenue to pay interest. So, interest rates must come down substantially, or else, we are in trouble" (Amaefule \& Asu, 2017).

The debt management provisions of the Fiscal Responsibility Act 2007 would benefit from explicit measures to manage breach of obligations, and stipulation of remedies. To illustrate, public borrowing has been restrained where the law stipulates corrective measures, i.e., S43(2) of the FRA 2007 which stipulates that loan repayments of SubNational Governments are deducted from federal allocations. However, S42(1) of the FRA 2007, which mandates the President to set debt limits for all levels of Government has not been implemented. Thus, S42(6) of the FRA 2007 which prohibits borrowing by Governments which have exceeded borrowing limits cannot be enforced. Similarly, S45(1) requires Financial Institutions to validate compliance of borrower Governments 
with S44(1), and S45(2) goes further to make it unlawful for Financial Institutions to lend to Governments without validation of compliance with the provisions of S44 (costbenefit analysis, necessary authorisation for borrowing, and purpose of borrowing). Even so, the law does not detail the mechanisms, benchmarks or criteria by which Financial Institutions should confirm that Governments intend to utilise debt finance for capital projects. The law does not specify a mechanism or institution to monitor the performance of functions imposed upon lender financial institutions, nor does it state punitive measures or remedies in the event of breach of the obligations placed upon Financial Institutions. Thus, I would argue that where legal reforms create obligations upon institutions or persons, these obligations should be accompanied by definitive corrective or remedial measures.

Chapter 4 of this thesis discusses the debt portfolios of Nigeria and Rwanda, particularly the tendency, in both countries, to utilise debt financing on recurrent and regular expenditure purposes. To some extent, borrowing by the Government of Rwanda has been better reported and utilised: recent borrowing has been linked to specific projects, such as the expansion of RwandAir (the state-owned airline) and the construction of the Kigali Convention Centre. Also, the Government guarantees only those loans obtained by RwandAir and the Rwanda Energy Group (See 4.5). Importantly, government borrowing is centralised through the Ministry of Finance and Economic Planning (See 4.5). Per Article 51 of the Law on State Finances and Property 2013, the government may borrow for general budgetary purposes. In this approach, there is the risk of creating a dependency on debt finance, especially as the Law does not provide tools by which to measure the effectiveness of government borrowing. Thus, all types of government expenditure can be sourced by debt finance, subject only to debt limits.

Chapter 4 also notes that despite PRSPs, fundamental economic problems have not been addressed, with the economies of both countries as vulnerable in 2017 to external shocks as they were in the 1970s. Thus, it can be argued that is it necessary for the legal instruments introduced to manage public finance to better direct government use of public finance, particularly debt finance towards developmental purposes. A review of government borrowing from the post-independence era will validate that in Nigeria and Rwanda, government deployment of finance is directed by the prevailing economic theory of the era: during the 1970s, governments prosecuted the Import Substitution Industrialisation economic model, and state funds were used to expand the role of government in national economies (Okonjo-Iweala, 2012). In the 1980s, reductions in government revenue, and SAPs directed by the IFIs introduced the notion of private sector led development, and constrained government participation in economic development (See 2.2).

Thus, if the ideology of this era is country-led economic development, underpinned by legislation and implemented through institutions, then it becomes logical to expect budgetary legislation to direct government use of debt finance towards developmental purposes. In Nigeria and Rwanda, budgetary legislations were introduced in the context 
of wider economic and institutional reforms to improve economic performance and management, as organised through the PRSP process. While it is acknowledged that the issue of utilisation of debt finance is part of the wider debate on institutional effectiveness, it is possible to consider the elements of conceptualisation and implementation which would improve the effectiveness of the debt management provisions of budgetary legislations in Nigeria and Rwanda.

I would argue that the limitations of the effectiveness of budgetary legislations in the area of debt management, can be attributed to the benchmarking of legal reforms, and the evaluation of laws. On benchmarking, the introduction of budgetary legislations in Nigeria and Rwanda followed the orthodox approach, i.e., conceptualisation and effectiveness of legal reforms are benchmarked against ideal notions of good law (See 3.2). However, they do not directly support the achievement of a central objective of debt relief, i.e., to increase government spending on developmental objectives. Thus, the changes intended by legal reforms are not explicitly expressed. As stated above, laws serve as mental constructs, capable of creating thought systems and influencing institutional practices. It can be argued that the borrowing practices of government have not fundamentally changed because the laws do not drive and direct a shift in intellectual and behavioural approaches of government institutions. On evaluation, typical assessments of law measure the quality of law, as well as the quality of implementation, on a reflective basis. However, if benchmarking and conceptualisation of legal reforms are problematic, it follows that evaluation will be based on a faulty premise, as discussed in the wrong classification of Nigeria and Rwanda (See 5.1).

\subsection{Contributions to Field of Study}

Asserting a contribution to a field of study is rather an audacious endeavour. Nonetheless, mapping the economic and political trajectory of Nigeria and Rwanda since the 1960s, I have shown that law has served as an instrument to drive economic development in Africa for several decades. Law is an instrument, capable of utilization in any number of contexts, for a broad range of purposes. For African countries, law can work for the achievement of economic objectives, divergent as these may well be across 54 countries. There have been several waves of legal reform in Africa; from the 1960s until the current era. Through these waves, a consistent feature of laws is that they 1) reflect an ideological stance, e.g., private sector or government-led development, and 2) are deployed as a 'missing component', which, when inserted will enable the engine of the economy operate in an optimal manner. The main contribution of this study is thus: effective laws must, of necessity, be responsive to the needs and changes within the economy, and political economy. Importantly, laws should be subjected to periodic evaluation against the stated outcomes or stated intentions which underpin their introduction, utilization, and operation in relevant areas of remit. 
Rather than asking whether law or institutions are good or bad, I would argue that the perspective should shift to good or bad outcomes from law and institutions. Furthermore, the evaluation of effectiveness of legal systems should move from the recreation of ideal features, or checking compliance with established benchmarks, towards the incorporation of practical evaluations of effects, outcomes and results. Nigeria and Rwanda have enacted budgetary legislations. The Governments of both countries have also, to significant extent, complied with the provisions of the legislation. However, gaps in the design of laws, or the narrow conception of the debt management provisions of the relevant laws have not prevented the build-up of debt obligations.

What do these findings imply for legal reformers? Firstly, there is an opportunity to enhance the way legal systems work in, and for African economies. However, the problem of benchmarking of laws must be addressed squarely and definitively. While there are lessons to be learned from looking at the way laws work in other systems, the approach to legal reform should shift from recreation of idealized legal systems, to creation of legal frameworks suited to, and effective for purpose. Legal reforms must holistically define problems, conceptualise interventions for economic effectiveness, and carefully consider the changes and outcomes to be created, even as they acknowledge and account for the existence and influence of the factors which will determine the extent of success.

Secondly, law, through legal reforms, reshapes institutional and relational dynamics, even as it frames opportunities and outcomes. In this light, legal reformers must adopt an approach which is both responsible and aware of the power structures, capabilities, and economic changes created by legal systems. Laws create mental constructs, which direct behaviours and functions which create economic outcomes. Thus, effective legal reforms will explicitly state and define the changes in thought systems and institutional functions.

Thirdly, in the context of institutional thought, laws can certainly be described as institutions. However, law-institutions operate in the climate created by other institutions, such as mental constructs. Also, law creates climatic conditions in which other institutions function. Laws and other types of institutions (organizations, mental constructs, and relationships, etc.) are inter-dependent, interacting in a dynamic manner. However, it is important to consider laws and legal systems, as distinct from other types of institutions. The characteristics of law, i.e., binding, non-negotiable, and benchmarksetting render it as an instrument to which other types of institutions look to for guidance. Thus, it is crucial that laws are relevant and suitable for the purposes to which they are deployed. 


\subsection{Limitations of Study}

Nigeria and Rwanda are but two of the fifty-four countries on the African continent. It cannot be claimed that their experiences are in any way representative of all, or even some countries in Africa. Also, within the study, it may be that the investigation of Nigeria would on occasion, seem deeper than that of Rwanda. Nigeria is my country of origin, and I am more familiar with its history and political arrangements, than I am with those of Rwanda.

The field of Law and Development is vast and uncharted in many areas. In this study, I have concentrated on the interaction of law and institutions in the economic sphere, and even then, a narrow analysis of the use of law by governments and international finance institutions in the public finance management systems of two countries. It is likely that different findings will be generated in other fields of study, e.g., private law, or in social development, as well as other regions.

Also, I have not presumed to delve into the arguments over primacy of institutional development, or engage in the question of what institutions matter for development. Instead, I have centred on the review of legal and institutional reforms undertaken for debt relief, and debt management, in Nigeria and Rwanda.

In addition, I have deliberately refrained from engaging in evaluations of economic policy or economic outcomes, and confined myself to interpretations of economic data. Firstly, evaluations of economic policy would have rendered the scope of investigation wide, and ultimately cumbersome. Secondly, legal education equips me to utilise the case-study model of investigation, interrogation and argument. Economic evaluation would have taken the study into the realm of econometric analysis, which is currently beyond the scope of my abilities.

Furthermore, I do not consider the process of law-making, e.g., the negotiations between governments and the IMF/World Bank during debt relief negotiations. The thesis follows the premise that National Parliaments enacted budgetary legislations, which are applied by government institutions. Perhaps a different study can scrutinise the mechanisms by which legislations were enacted during the PRSP process.

\subsection{Opportunities for Further Research}

The effect of law on economic development can be further studied from several perspectives. The study of laws as they influence government behaviour in public finance can be expanded to include more countries, particularly in public debt management, which is prescient for many African countries.

Also, following the methodology used in this thesis, i.e., a comparative study of the interactions of law and economies in public and private spheres would be interesting. The differences in context are bound to yield interesting insights on the effect of laws 
on behaviours of various types of actors, and the outcomes in relationships, perceptions/use of law, and economic systems at micro and macro levels.

Furthermore, the proposition of this thesis, i.e., that the effectiveness of legal reforms should be evaluated against outcomes can be attempted from academic and policy perspectives. Diagnosis of contexts can be conducted in the areas of public or private law, in order to map strategies which would direct the workings of legal systems towards intended outcomes.

\subsection{Concluding Statement}

This thesis has highlighted the multidimensional capacities of law including; legal instruments as the creators of mental constructs and patterns of thinking, the arbiters of institutional relations, the benchmarks for the measurement of institutional behaviour and tools for economic management. Contemporary African development has been accompanied by several generations of legal reforms to aid the prosecution of economic development agenda. Law can, and does serve as an instrument of economic development on the African continent. However, the quality and impact of law, are made evident not only in its existence, but through the interplay of laws and institutions, congruent towards the achievement of economic objectives. 
Chapter

Valorisation Addendum 

Pursuant to the Regulations of Maastricht University, I am required to include a piece on Valorisation, or a brief discussion on the application of this thesis for social/economic use. Thus, in this section, I attempt to answer the five questions presented in the Maastricht University PhD Regulations:

\section{Relevance: What is the social (and/or economic) relevance of your research results (i.e. in addition to the scientific relevance)?}

The central question- 'how can law drive economic development in Africa?' guided the study towards the observation and analysis of the interplay of law, institutions and economic performance. Specifically, the thesis evaluated the effectiveness of law in directing the behaviour of the Governments of Nigeria and Rwanda in the management of public debt.

\section{How are the results of my research relevant?}

In October 2017, the President of the Federal Republic of Nigeria requested permission from the National Assembly to increase the country's external debt portfolio by US\$5billion, to finance infrastructure projects. US\$3billion is to be sourced through a Eurobond, and US\$2billion on the International Capital Market (Umoru, 2017). At the time of writing this Valorisation addendum, the National Assembly has yet to provide a response to the Presidency. The Debt Management Office estimates that this borrowing will be repaid over a period of between 5 to 30 years (Baiyewu, 2017). It is interesting to note that in July 2017, the Minister of Finance warned that Nigeria should no longer finance her budget through debt finance. Her words: "we cannot borrow anymore, we just have to generate funds domestically to fund our budget. Mobilise revenue to fund the necessary budget increase" (Ogunmade \& Chima, 2017).

For myself, (and I would imagine, millions of young Nigerians of working age), this sounds like the Government plans to borrow more money at my expense. To be fair, successive governments have borrowed extensively on behalf of the country and her people. However, writing a thesis on debt finance at a time of heavy national borrowing renders the borrowing numbers vivid and personal. Indeed, the questions asked in the thesis, particularly those relating to the monitoring and use of debt finance become compelling and important.

Since the 1990s, governance and the rule of law have been presented by NIE and International Finance Institutions as critical elements for the achievement of developmental goals. Over the last two decades, legal reforms in Africa have attempted to use laws as tools to structure societies and create beneficial results. Chapters 3, 4 and 5 of this thesis discuss the application and effectiveness of laws in regulating the behaviour of the Governments of Nigeria and Rwanda in the area of debt management.

Law is important, and law is powerful. Also, governments do shape the trajectory and quality of life for their citizens and residents. I argued in this thesis that laws should 
be evaluated against outcomes within the relevant context. Thus, measuring law against outcomes (intended and unintended), would support not only the evaluation of the effectiveness of laws. Importantly, it allows the observation of the effect of legal stipulations on institutional behaviour, and by extension economic and societal results. Where law has been deployed as a tool of economic management, it is important for all stakeholders, whether citizens, governments, development partners, and in the context of this thesis, creditors, to evaluate its usefulness, effectiveness for the purposes deployed.

Also, where law is the tool of economic management, it is placed as the location for negotiation and disputation for all interest groups. It follows that the discourse on the rule of law needs to extend beyond the application of laws, to the analysis of the effect and suitability of laws. The quality of laws, and their effectiveness for achieving developmental goals would be improved through regular evaluation and critical reflection of the interaction of laws, institutions and economic outcomes, by all stakeholders.

\section{2. (Target groups) To whom, in addition to the academic community, are your research results of interest and why?}

The widespread acceptance of governance, institutions, and the rule of law for development lies in the adoption of the governance agenda by International Finance Institutions, particularly the World Bank, itself influenced by the work of economistacademics. In addition, governments, whether willingly or unwillingly, have pursued the governance agenda. Similarly, civil society organisations have championed the governance agenda, and attempt to hold governments accountable.

It may be that the approach and tools discussed in this thesis, particularly evaluating law against outcomes, would be useful to all the stakeholders mentioned in the paragraph above. Also, within the legal profession and academic community, it may be possible to explore the development of tools, such as indexes, and platforms, such as dialogues to examine the quality, suitability and effectiveness of laws in different spheres. This would be interesting, I believe, to see how laws interact with institutions at microlevel, e.g., public debt, public spending, property rights. Also, it might be intriguing to conduct such an evaluation on a comparative basis within countries, to observe the interplay, and (perhaps) conflicts of legal regimes within national economies.

Furthermore, public officials and law makers might consider the questions asked in Chapter 5 of this thesis relevant in the law-making process. Where law is introduced as tool to drive development, it is critical to state clearly the objectives of development, and the metrics by which these objectives will be measured. In Chapter 4 of the thesis, I outlined some of the limitations of legal reforms, e.g., political/administrative systems. The importance of 'localising' laws cannot be overstated. As I observed in Chapter 5, legal transplantation is often the easiest way of law-making. Nonetheless, it is important 
for law-makers to thoroughly scope the political, administrative and intellectual contexts in which laws will be applied, and then render laws fit for purpose.

\section{Activities/Products: Into which concrete products, services, processes, activities or commercial activities will your results be translated and shaped?}

There are several opportunities to translate the arguments and insights of this thesis into products and activities. Firstly, the 'assessment tool' presented in Chapter 5, by which law can be measured against outcomes can be further developed for use by different stakeholders. Thereafter, the tool can be deployed by myself and other researchers/research institutes to conduct evaluations of legal frameworks within specific economic contexts. Thereafter, with the findings of these evaluations, it would be possible to engage with academia, the legal profession and International Finance Institutions. These engagements can occur through research programmes, conferences, workshops and other opportunities as may be explored.

\section{Innovation: To what degree can your results be called innovative in respect to the existing range of products, services, processes, activities and commercial activities?}

It has been said, by no less than authority than Scripture, that there is nothing new under the sun (Ecclesiastes 1:9). However, I hope that in this thesis, on a practical level, I have submitted simple and actionable proposals by which law can be used as an instrument of development, especially on the African continent.

Existing tools for the evaluation of law, for example, the Country Policy and Institutional Assessment and the Doing Business Index, are applied on a global, comparative basis. I have argued that it is also necessary to evaluate laws against outcomes within national economies. Also, provided in Chapter 5 are sample tools by which this may be prosecuted. While these tools will be further refined in application, they are different to existing tools in several respects:

a) Purpose: the popular indexes (CPIA, DB) are owned and populated by the Staff of International Finance Institutions for the purposes of assessing economic/institutional performance, and for resource allocation. The tools for outcomebased evaluation are intended to evaluate the effectiveness and suitability of laws for the achievement of developmental objectives.

b) Approach: the outcome-based approach of the evaluation of laws uses as a benchmark the stated objectives of legal instruments, rather than 'ideal law' benchmarks. Also, the outcome based approach is different in that it considers both intended and unintended outcomes of the application of legal instruments. 
Ownership: I will claim copyright of these tools. However, the tools used for the evaluation law against outcomes can be adapted and used within different contexts.

5. Schedule \& Implementation: How will this/these plan(s) for valorisation be shaped? What is the schedule, are there risks involved, what market opportunities are there and what are the costs involved?

In the immediate future, these tools can be applied within research and policy initiatives within the fields of law and economic development. There are plentiful opportunities within rule of law and governance programs to undertake practical evaluation of the effect of laws within economies. As the tools have been presented in this thesis, they can be deployed without further significant cost, applied in their current state, and refined as they are utilised. 


\section{Bibliography}

Acemoglu, D., \& Robinson, J. A. (2012). Why Nations Fail The Origins of Power, Poverty and Prosperity. New York: Crown Business.

Acemoglu, D., Collier, P., Johnson, S., Klein, M., \& Wheeler, G. (2013). A Review of Doing Business. Washington DC: World Bank.

Acemoglu, D., Johnson, S., \& Robinson, J. A. (2001). The Colonial Origins of Comparative Development: An Empirical Investigation. The American Economic Review, 91. No. 5, 1369-1401.

Adelman, I. (2001). Fifty Years of Economic Development: What Have We Learned? Paris: Annual Bank Conference on Development Economics in Europe Proceedings: 1999-2000; [Conference Governance, Equity and Global Markets; Conference Development Thinking at the Millennium].

Advocacy International. (2000). Jubilee 2000. Retrieved November 3, 2016, from http://advocacyinter national.co.uk/featured-project/jubilee-2000

African Development Bank. (2001). Rwanda- HIPC Approval Document- Decision Point Under the Enhanced Framework. Abidjan: African Development Bank.

African Development Bank. (2017). Country Policy and Institutional Assessment. Retrieved May 11, 2017, from https://cpia.afdb.org/?page=methodology

African Development Bank Group. (2001). Rwanda-HIPC Approval Document-Decision Point Under the Enhanced Framework. Abidjan: African Development Bank.

African Development Bank Group. (2011). Agreement Establishing the African Development Bank. Abidjan: African Development Bank.

African Development Bank Group. (n.d.). Frequently Asked Questions. Retrieved November 10, 2016, from http://www.afdb.org/en/about-us/frequently-asked-questions/

African Development Bank Group. (n.d.). Types of Financial Instruments. Retrieved November 10, 2016, from http://www.afdb.org/en/topics-and-sectors/sectors/private-sector/types-of-financial-instruments/

Agbese, D. (2016, December 11). A Jumbo Loan is a Bad Option. Retrieved February 19, 2017, from http://www.dailytrust.com.ng/news/viewpoint/a-jumbo-loan-is-a-bad-option/175444.html

Albers, P. (2007). How to measure the rule of law: a comparison of three studies. Conference paper Rule of Law Conference. The Hague: Hague Institute for Internationalisation and Law.

Alexander, R. J. (1967). The Import-Substitution Strategy of Economic Development. Journal of Economic Issues, 1(4), 297-308.

Aluko, M. (2001, May). Tackling Nigeria's External Debt. Retrieved October 19, 2016, from http://www.afbis. com/articles/debt_nig.htm

Amaefule, E., \& Asu, F. (2017, June 7). N19tn debt: NESG, Utomi, Rewane, others call for caution. Retrieved June 12, 2017, from http://punchng.com/n19tn-debt-nesg-utomi-rewane-others-call-for-caution/

Andersen, R. (2000). How Multilateral Development Assistance Triggered the Conflict in Rwanda. Third World Quarterly, 21(3), 441-456.

Andrews, M. (2013). The Limits of Institutional Reform in Development. New York: Cambridge University Press.

Anyanwu, J. C. (1992). President Babangida's Structural Adjustment Programme and Inflation in Nigeria. Journal of Social Development in Africa, 7(1), 5-24.

Armour, J., Deakin, S., Lele, P., \& Siems, M. (2009). How Do Legal Rules Evolve? Evidence from a Cross-Country Comparison of Shareholder, Creditor, and Worker Protection. The American Journal of Comparative Law, 57(3), 579-629. 
Babatunde, M. A. (2012). Africa's Growth and Development Strategies: A Critical Review. African Development, 37(4), 141-178.

Baiyewu, L. (2017, October 20). Nigerians may repay $\$ 5.5$ bn loan for 30 years, says FG. Retrieved October 22, 2017, from http://punchng.com/nigerians-may-repay-5-5bn-loan-for-30-years-says-fg/

Baker, R. (1970). Reorientation in Rwanda. The Royal African Society, 69(275), 141-154.

Barak-Erez, D. (2014). Legislation as Transplantation. In N. Lupo, \& L. Scaffardi (Eds.), Comparative Law in Legislative Drafting: The Increasing Importance of Dialogue Amongst Parliaments (pp. 17-28). The Hague: Eleven International Publishing .

Barron, G. (2005). Working Paper Series No 05-70. The World Bank \& Rule of Law Reforms. London: London School of Economics and Political Science.

Berkowitz, D., Pistor, K., \& Richard, J.-F. (2001). Economic Development, Legality, and the Transplant Effect. William Davidson Working Paper Number 410. Ann Arbor: William Davidson Institute.

Bhattacharya, A. (2004). From Debt Relief to Achieving the Millennium Development Goals. In J. J. Teunissen, \& A. Akkerman (Eds.), HIPC and Debt Relief-Myths and Reality (pp. 98-106). The Hague: Forum for Debt and Development.

Birdsall, N., Williamson, J., \& Deese, B. (2002). Delivering on Debt Relief: From IMF Gold to New Aid Architecture. Washington DC: Peterson Institute for International Economics.

Biron, L. C. (2013, June 24). World Bank Formally Urged to Overhaul 'Doing Business' Report. Retrieved June 4, 2017, from http://www.ipsnews.net/2013/06/world-bank-formally-urged-to-overhaul-doing-business-report/

Bretton Woods Project. (2016, March 31). IMF and World Bank Decision Making and Governance. Retrieved November 12, 2016, from http://www.brettonwoodsproject.org/2016/03/imf-world-bank-decisionmaking-and-governance-existing-structures-and-reform-processes/

British Broadcasting Corporation. (2011, May 17). Rwanda: How the genocide happened. Retrieved October 24, 2016, from http://www.bbc.com/news/world-africa-13431486

BudgIT. (2017, March 3). Nigeria's Debt Management System.

Business Day. (2013, April 8). Rwanda plans debut $\$ 400$ million eurobond. Retrieved March 25, 2017, from https://www.businessdayonline.com/rwanda-plans-debut-400-million-eurobond/

Carothers, T. (2003). Working Papers. Promoting the Rule of Law Abroad, The Problem of Knowledge. Washington DC: Carnegie Endowment for International Peace.

Cassimon, D., Essers, D., \& Verbeke, K. (2016). Working Paper No 14. The Changing Face of Rwanda's Public Debt. Namur: Belgian Policy Research Group on Financing for Development .

Chang, H. (1999). The Economic Theory of the Developmental State. In M. Woo-Cummings (Ed.), The Developmental State. New York : Cornell University Press.

Chang, H. J. (2007). Institutional Change and Economic Development. London: Anthem Press.

Chirwa, M. (2015). Rwanda, Is It A Success Story or Exaggerated? Development History. European Scientific Journal, 11(20).

Chossudovsky, M. (1995, January 26). IMF-World Bank policies and the Rwandan holocaust. Retrieved April 26, 2017, from http://www.hartford-hwp.com/archives/35/033.html

Chossudovsky, M., \& Galand, P. (2004, March 30). The Use of Rwanda's External Debt (1990-1994) The Responsibility of Donors and Creditors. Retrieved April 26, 2017, from http://www.globalresearch.ca/ articles/CHO403E.html

Cline, W. R. (1983). International Debt and the Stability of the World Economy. Volume 4 of Policy Analyses in International Economics (Vol. 4). Washington DC: Institute for International Economics.

Collignon, S. (2012). Fiscal Policy Rules and the Sustainability of Public Debt in Europe. International Economic Review, 53(2), 539-567.

Daily Post. (2013, June 25). IBB's Structural Adjustment Programme destroyed Nigeria's Civil Service - Imoke. Retrieved October 20, 2016, from http://dailypost.ng/2013/06/25/ibbs-structural-adjustment-programmedestroyed-nigerias-civil-service-imoke/

Davis, K. E., \& Trebilcock, M. J. (2008). The Relationship between Law and Development: Optimists versus Skeptics. The American Journal of Comparative Law, 56 No. 4, 895-946.

De Soto, H. (1989). The Other Path: The Economic Answer to Terrorism. New York: Basic Books. 
Debt Management Office. (2005). Nigeria's Debt Relief Deal with the Paris Club. Abuja: Debt Management Office.

Debt Management Office. (2016). 2016 Report of the Annual National Debt Sustainability Analysis (DSA). Abuja: Debt Management Office.

Debt Management Office. (2016). Nigeria's Debt Management Strategy, 2016-2019. Abuja: Debt Management Office.

Debt Management Office. (n.d.). Nigeria's External and Domestic Debt. Retrieved October 20, 2016, from https://www.dmo.gov.ng/debt-relief\#nigeria-s-external-and-domestic-debt

Denny, C., \& Elliot, L. (1999, December 31). The Spark that Lit Global Revolt against Poverty. Retrieved November 10, 2016, from https://www.globalpolicy.org/component/content/article/209/43193.html

Djankov, S., McLiesh, C., \& Ramalho, R. (2006). Regulation and Growth. Washington DC: World Bank.

Du, J. (2011). Does China Need Law for Economic Development? In M. Faure, \& J. Smits (Eds.), Does Law Matter? On Law and Economic Growth. Cambridge: Intersentia.

European Commission. (2015, January 13). European Commission - Fact Sheet Commission issues guidance to encourage structural reforms and investment - Frequently Asked Questions. Retrieved March 18, 2017, from http://europa.eu/rapid/press-release_MEMO-15-3221_en.htm

European Network on Debt and Development. (2006). World Bank and IMF conditionality: A Development Injustice. Brussels: European Network on Debt and Development.

European Union. (2007). Treaty on the Functioning of the European Union. European Union.

Eze, O. C. (2014). National Economic Empowerment and Development Strategies (NEEDS) and Labour in Nigeria, 2003-2007. Journal of Good Governance and Sustainable Development in Africa, 2(2), 152-161.

Fattouh, B. (2007). OPEC Pricing Power. The Need for a New Perspective. Oxford: Oxford Institute for Energy Studies.

Faure, M., Goodwin, M., \& Weber, F. (2010). Bucking the Kuznets Curve: Designing Effective Environmental Regulation in Developing Countries. Virgina Journal of International Law, 51(95), 85-157.

Forum on Debt and Development. (1992). African Debt Revisited: Procrastination or Progress? The Hague: Forum for Debt and Development.

Frank, A. G. (1966). The Development of Underdevelopment. Monthly Review, 18(4).

Fritz, V., Fialho Lopes, A., Hedger, E., Tavakoli, H., \& Krause, P. (2012). Public Financial Management in Postconflict Countries. Washington DC: World Bank.

G-24 . (2003). Secretariat Briefing paper on the Heavily Indebted Poor Country (HIPC) Initiative. Washington DC: G-24.

Gakunzi, G. (2017, March 10). Rwanda's Debt Management System.

Garoupa, N., \& Ogus, A. (2006). A Strategic Interpretation of Legal Transplants. Journal of Legal Studies, 35(2), 339-363.

Gasana, J. (2002). Remember Rwanda? Massachusetts : WorldWatch Institute.

General Agreement on Tarrifs and Trade. (1948). Text of the General Agreement.

Global Policy Forum. (2014 , October 28). Trade unions and campaigners slam "strongly flawed" Doing Business report, after World Bank snubs call by two independent panels for root and branch reform. Retrieved June 4, 2017, from https://www.globalpolicy.org/global-taxes/52703-doing-business-reportstrongly-flawed.html

Gray, C. W. (1997). Reforming Legal Systems in Developing and Transition Countries. Finance \& Development, 34(3), 14-16.

Greenhill, R. (2002). The Unbreakable Link- Debt Relief and the Millennium Development Goals. London: New Economics Foundation.

Griffith-Jones, S. (2002). Governance of the World Bank. London: Department for International Development . Hanlon, J. (1998). African Debt Hoax. Review of African Political Economy, 25(77), 487-492.

Harrison, G. (2004). HIPC \& the Architecture of Governance. Review of African Political Economy, 31(99), 125128.

Harris-White, B. (2003). On Understanding Markets as Social and Political Institutions in Developing Economies. In H. J. Chang (Ed.), Rethinking Development Economics. London: Anthem Press. 
Harvard Law School. (1961). Report of the Director 1954-1961. Cambridge: International Legal Studies. Helland, E., \& Klick, J. (2011). Legal Origins and Empirical Credibility . In M. Faure, \& J. Smits (Eds.), Does Law Matter? On Law and Economic Growth (pp. 99-112). Cambridge: Intersentia.

Hintjens, H. M. (1999). Explaining the 1994 genocide in Rwanda. Journal of Modern African Studies, 37(2), 241-286.

Howse, R. (2007). The Concept of Odious Debt in Public International Law. Geneva: United Nations Conference on Trade and Development.

Hubli, S. K., \& Mandaville, P. A. (2004). Parliaments and the PRSP Process. Washington DC: World Bank Institute.

IFC Asset Management Company. (n.d.). About Us. Retrieved November 10, 2016, from http://www.ifcamc.org/ about-us

Ijeoma, N. B. (2013). An Empirical Analysis of the Impact of Debt on the Nigerian Economy. International Journal of Arts and Humanities, Bahir Dar, Ethiopia, 2 (3)(7), 165-191.

International Development Association and International Monetary Fund. (2001, April 20). The Challenge of Maintaining Long-Term External Debt Sustainability. Retrieved December 8, 2016, from https://www.imf.org/external/np/hipc/2001/lt/042001.pdf

International Development Association and International Monetary Fund. (2013). Joint Bank-Fund Debt Sustainability Analysis - 2013 Update. Washington DC: International Development Association.

International Finance Corporation. (n.d.). Solution. Retrieved November 10, 2016, from http://www.ifc.org/wps/wcm/connect/CORP_EXT_Content/IFC_External_Corporate_Site/solutions

International Labour Organization. (2006). Poverty Reduction Strategy Papers. A Guide For Employers' Organizations. Geneva: International Labour Organization.

International Monetary Fund . (2016). Rwanda Fifth Review under the Policy Support Instrument and Request for Extension, and Request for an Arrangement under the Standby Credit Facility- Debt Sustainability Analysis. Washington DC: International Monetary Fund.

International Monetary Fund. (1944). Articles of Agreement. Washington DC: International Monetary Fund.

International Monetary Fund. (1997). Good Governance The IMF's Role. Washington D.C: International Monetary Fund.

International Monetary Fund. (1999). From Toronto Terms to the HIPC Initiative: A Brief History of Debt Relief for Low-Income Countries. Washington DC: International Monetary Fund.

International Monetary Fund. (1999). Poverty Reduction Strategy Papers--Operational Issues. Washington DC: International Monetary Fund.

International Monetary Fund. (2000, April 12). Debt Relief, Globalization, and IMF Reform: Some Questions and Answers. Retrieved November 2, 2016, from https://www.imf.org/external/np/exr/ib/2000/041200b.htm International Monetary Fund. (2000, September). The Logic of Debt Relief for the Poorest Countries. Retrieved December 8, 2016, from https://www.imf.org/external/np/exr/ib/2000/092300.htm\#III

International Monetary Fund. (2003). Growth and Institutions. In I. M. Fund (Ed.), World Economic Outlook: Growth and Institutions. Washington DC: International Monetary Fund.

International Monetary Fund. (2004, April). IMF Concessional Financing through the ESAF- A Factsheet. Retrieved December 8, 2016, from https://www.imf.org/external/np/exr/facts/esaf.htm

International Monetary Fund. (2005, December 23). Press Release: IMF to Extend 100 Percent Debt Relief to

Rwanda Under the Multilateral Debt Relief Initiative. Retrieved February 11, 2017, from https://www.imf.org/en/News/Articles/2015/09/14/01/49/pr05301

International Monetary Fund. (2005). Rwanda: Poverty Reduction Strategy Paper Annual Progress Report IMF Country Report No. 05/127. Washington DC: International Monetary Fund.

International Monetary Fund. (2006). Rwanda: Poverty Reduction Strategy Paper-Annual Progress Report IMF Country Report No. 06/61. Washington DC: International Monetary Fund.

International Monetary Fund. (2007). Nigeria: Poverty Reduction Strategy Paper-Progress Report. IMF Country Report No. 07/270. Washington DC: International Monetary Fund.

International Monetary Fund. (2008). Rwanda Poverty Reduction Strategy Paper IMF Country Report No. 08/90. Washington DC: International Monetary Fund. 
International Monetary Fund. (2009, July 31). The Poverty Reduction and Growth Facility (PRGF). Retrieved December 8, 2016, from https://www.imf.org/external/np/exr/facts/prgf.htm

International Monetary Fund. (2012). NIGERIA. SSTAFF REPORT FOR THE 2011 ARTICLE IV CONSULTATIONDEBT SUSTAINABILITY ANALYSIS. Washington DC: International Monetary Fund.

International Monetary Fund. (2016, September 20). Debt Relief Under the Heavily Indebted Poor Countries (HIPC) Initiative. Retrieved November 11, 2016, from http://www.imf.org/en/About/Factsheets/Sheets/ 2016/08/01/16/11/Debt-Relief-Under-the-Heavily-Indebted-Poor-Countries-Initiative

International Monetary Fund. (2016). Debt Relief Under the Heavily Indebted Poor Countries (HIPC) Initiative. Washington DC: International Monetary Fund.

International Monetary Fund. (2016, September 20). Factsheet- The Multilateral Debt Relief Initiative. Retrieved December 8, 2016, from http://www.imf.org/en/About/Factsheets/Sheets/2016/08/01/16/11/ Debt-Relief-Under-the-Heavily-Indebted-Poor-Countries-Initiative

International Monetary Fund. (2016, September 27). IMF Conditionality. Retrieved October 28, 2016, from https://www.imf.org/en/About/Factsheets/Sheets/2016/08/02/21/28/IMF-Conditionality

International Monetary Fund. (2016, October 3). IMF Lending. Retrieved November 9, 2016, from http://www.imf.org/en/About/Factsheets/IMF-Lending

International Monetary Fund. (2016, September 27). IMF Standing Borrowing Arrangements. Retrieved November 9, 2016, from https://www.imf.org/en/About/Factsheets/Sheets/2016/08/05/17/55/IMFStanding-Borrowing-Arrangements

International Monetary Fund. (2016, December 28). Poverty Reduction Strategy Papers (PRSP). Retrieved April 4, 2017, from http://www.imf.org/external/np/prsp/prsp.aspx

International Monetary Fund. (2016, June 8). Press Release: IMF Executive Board Approves US\$204 Million Stand-by Credit Facility for Rwanda and Completes Fifth PSI Review. Press Release No. 16/270. Retrieved March 25, 2017, from http://www.imf.org/external/np/sec/pr/2016/pr16270.htm

International Monetary Fund. (2016, September 30). The Joint World Bank-IMF Debt Sustainability Framework for Low-Income Countries. Retrieved March 10, 2017, from http://www.imf.org/external/np/exr/facts/jdsf.htm

International Monetary Fund. (2017, April 17). Factsheet-Poverty Reduction Strategies in IMF-supported Programs. Washington DC: International Monetary Fund .

International Monetary Fund. (2017). List of Members. Retrieved May 17, 2017, from https://www.imf.org/external/np/sec/memdir/memdate.htm

International Monetary Fund. (n.d.). Rwanda--Enhanced Structural Adjustment Facility Economic and Financial Policy Framework Paper for 1998/99--2000/01. Retrieved October 24, 2016, from https://www.imf.org/external/np/pfp/rwanda/rwanda01.htm

Isar, S. (2012). Was the Highly Indebted Poor Country Initiative (HIPC) A Success? Consilience: The Journal of Sustainable Development, 9(7), 107-122.

Jannah, C. (2017, February 20). Dogara blames Nigeria's recession on Niger-Delta militants. Retrieved April 4, 2017, from http://dailypost.ng/2017/02/20/dogara-blames-nigerias-recession-niger-delta-militants/

Joint Evaluation of Emergency Assistance to Rwanda . (1996). The International Response to Conflict and Genocide: Lessons from the Rwanda Experience. Study 1 Historical Perspective: Some Explanatory Factors . London: Overseas Development Institute.

Jubilee Debt Campaign. (n.d.). Facts and Statistics on Debt from Jubilee Debt Campaign. Retrieved November 11, 2016, from http://www.colorado.edu/AmStudies/lewis/ecology/debtcrisis.pdf

Kahn-Freund, O. (1974). On Uses and Misuses of Comparative Law. Modern Law Review, 37(1), 1-27.

Kanda, H., \& Milhaupt, J. C. (2003). Re-examining Legal Transplants: The Director's Fiduciary Duty in Japanese Cor. The American Journal of Comparative Law, 51(4), 887-901.

Kauffmann, D., \& Kraay, A. (2002). Growth without Governance. Washington DC: World Bank.

Kaufmann, D., Kraay, A., \& Zobido-Lobaton, P. (1999). Governance Matters. World Bank Policy Research Working Papers No. 2196. Washington DC: World Bank.

Kayigamba, J.-B. (1997, November 17). Shattered Rwanda Vows to Repay Billion Dollar Debt. Retrieved November 3, 2016, from https://journal.probeinternational.org/1997/11/17/shattered-rwanda-vowsrepay-billion-dollar-debt/ 
Kremer, M., \& Seema, J. (2002). Odious Debt. Finance and Development, 39(2).

Krugman, P. R. (1990). Debt Relief is Cheap. Foreign Policy, 80, 141-152.

Kumar, K., \& Tardif-Douglin, D. (1996). Rebuilding Postwar Rwanda The Role of the International Community. Washington DC: United States Agency for International Development.

La Porta, R., Lopez-de-Silanes, \& Shleifer, A. (2008). The Economic Consequences of Legal Origins. Journal of Economic Literature Vol. 46 No. 2, 46(2), 285-332.

Legal Vice Presidency, World Bank. (2003). Legal and Judicial Reform:Strategic Directions. Washington DC: World Bank Legal Vice Presidency.

Legrand, P. (1997). The Impossibility of Legal Transplants. Maastricht Journal of European and Comparative Law, 111.

Lewis, P. (1987, November 12). Accord Near on Aid to Poorest Africa Nations. Retrieved November 10, 2016, from http://www.nytimes.com/1987/11/12/world/accord-near-on-aid-to-poorest-africa-nations.html? pagewanted=all

Martin, M. (2004). Assessing the HIPC Initiative: The Key HIPC Debates. In J. J. Teunissen, \& A. Akkerman (Eds.), HIPC Debt Relief - Myths and Reality (pp. 11-38). The Hague: Forum for Debt and Development.

May, C. D. (1984, January 30). Nigeria's Search for Recovery. Retrieved February 19, 2017, from http://www.nytimes.com/1984/01/30/business/nigeria-s-search-for-recovery.html

Michaels, R. (2011). Functionalism of Legal Origins. In M. Faure, \& J. Smits (Eds.), Does Law Matter? On Law and Economic Growth (pp. 21-40). Cambridge: Intersentia.

Mihaupt, C. (2009). Beyond Legal Origin: Rethinking Law's Relationship to the Economy-Implications for Policy. The American Journal for Comparative Law, 57 No. 4, 831-845.

Milhaupt, C. (2009). Beyond Legal Origin: Rethinking Law's Relationship to the Economy-Implications for Policy. The American Journal for Comparative Law, 57(4), 831-845.

Ministry of Finance and Economic Planning. (2002). Poverty Reduction Strategy Paper. Kigali: Ministry of Finance and Economic Planning.

Ministry of Finance and Economic Planning. (2015). Medium Term Debt Strategy. Kigali : Ministry of Finance and Economic Planning.

Montesquieu, B. C. (1750). The Spirit of the Laws.

Moss, T. (2006). Briefing: The G8's Multilateral Debt Initiative and Poverty Reduction in sub-Saharan Africa. African Affairs, 105(419), 285-293.

Moss, T., Standley, S., \& Birdsall, N. (2004). Double-Standards, Debt Treatment, and World Bank Country Classification: The Case of Nigeria. Washington DC: Centre for Global Development.

Murenzi, C. (2010). Technical Paper The Role of Debt Management and Key Considerations for a Debt Office: the Case of Rwanda. Harare: Macroeconomic and Financial Institute of Eastern and Southern Africa.

National Assembly of Nigeria. (2003). Debt Management Office Establishment Act. Abuja: National Assembly of Nigeria.

National Assembly of Nigeria. (2007). The Fiscal Responsibility Act. Abuja: National Assembly of Nigeria .

National Bank of Rwanda. (2015). Debt Statistics. Kigali: National Bank of Rwanda.

National Centre for Economic Management \& Administration. (2004). Structural Adjustment Programme In Nigeria: Causes, Processes and Outcomes. New Delhi: www.nairametrics.com.

Nellis, J. (2005). The Evolution of Enterprise Reform in Africa: From State Owned Enterprises to Private Participation In Infrastracture-And Back? Washington D.C: International Bank for Reconstruction and Development/World Bank.

New Times. (2016, June 9). IMF approves Rwf159bn Standby Credit Facility for Rwanda. Retrieved March 25, 2017, from http://www.newtimes.co.rw/section/article/2016-06-09/200631/

News 24. (2005, April 14). Debt Relief for Rwanda. Retrieved February 11, 2017, from http://www.news24.com/Africa/Debt-relief-for-Rwanda-20050413

Nigerian National Planning Commission. (2004). Meeting Everyone's Needs- The National Economic Empowerment and Development Strategy. Nigerian National Planning Commission: Abuja.

North, D. (1995). The New Institutional Economics and Third World Development. In J. Harris, J. Hunter, \& C. Lewis (Eds.), Economics and Third World Development (pp. 17-26). London: Routledge. 
North, D. (1995). The New Institutional Economics and Third World Development. In J. Harris, J. Hunter, \& C. Lewis (Eds.), Economics and Third World Development. London: Routledge.

Nwachukwu, C., Nelson, C., \& Abuh, A. (2016, October 26). Buhari seeks approval to borrow N9.12tr in two years. Retrieved March 14, 2017, from https:/guardian.ng/news/buhari-seeks-approval-to-borrow-n912 tr-in-two-years/

Nwagbara, E. N. (2011). The Story of Structural Adjustment Programme in Nigeria From the Perspective of the Organised Labour. Australian Journal of Business and Management Research, 1(7), 30-41.

Ogundele, O. J., Hassan, A. R., \& Abdul-Azees, I. A. (2011). Projecting the Possible Impacts of the National Economic Empowerment. International Journal of Economics and Finance, 3(4), 162-169.

Ogunmade, O., \& Chima, O. (2017, July 12). Nigeria Can't Borrow Anymore, Warns Adeosun. Retrieved October 22, 2017, from https://www.thisdaylive.com/index.php/2017/07/12/nigeria-cant-borrowanymore-warns-adeosun/

Okonjo-Iweala, N. (2005). Understanding Nigeria's Debt Situation. Abuja: Debt Management Office Nigeria.

Okonjo-Iweala, N. (2012). Reforming the Unreformable Lessons from Nigeria. London: MIT Press.

Okoro, A. S. (2013). Public Debt. Abuja: Central Bank of Nigeria.

Okosodo, P. (2017, March 29). How do Nigerian Banks Manage Government Borrowing?

Omame, E. (2016, February 17). Nigeria: There's a Lot More to Learn From 'IBB's SAP' Than Meets the Eye. Retrieved February 19, 2017, from http://allafrica.com/stories/201602171002.html

Omoigui, I. (2017, February 22). PRSP Reforms and Debt Sustainability in Africa.

Opejobi, S. (2017, April 26). Buhari writes NASS again, seeks approval to borrow \$5.851bn foreign loan.

Retrieved June 22, 2017, from http://dailypost.ng/2017/04/26/buhari-writes-nass-seeks-approvalborrow-5-851bn-foreign-loan/

Organisation for Economic Cooperation and Development. (2016). General Government Debt. Retrieved August 11, 2017, from https://data.oecd.org/gga/general-government-debt.htm

Organisation of African Unity. (1980). Lagos Plan of Action. Addis Ababa: Organisation of African Union.

Oxfam. (2003). The IMF and the Millennium Goals. Failing to Deliver for Low Income Countries. Oxford: Oxfam.

Paris Club. (2005). Paris Club Agrees On A Comprehensive Treatment of Nigeria's Debt. Paris: Paris Club.

Parliament of Rwanda. (2006). Organic Law on State Finances and Property No 37/2006 of 12/09/2006. Kigali: Parliament of Rwanda.

Parliament of Rwanda. (2013). Organic Law No 12/2013/OL of 12/09/2013. Kigali: Parliament of Rwanda.

Perry, J. A. (2002). The Relationship between Legal Systems and Economic Development: Integrating Economic and Cultural Approaches. Journal of Law and Society, 29(2), 282-307.

Peterside, C. S. (2003, September 23). National Economic Empowerment \& Development Strategy (NEEDS)Analysis, Perspectives and Challenges. Retrieved December 12, 2016, from http://nigeriaworld.com/ articles/2003/sep/234.html

Pettifor, A., \& Greenhill, R. (2002). Debt Relief and the Millennium Development Goals. London: New Economics Foundation.

Prado, M. M. (2010, Octubre). What is Law \& Development? Revista Argentina de Teoria Juridica, 11.

Premium Times. (2014, April 7). Orosanye Report: Nigeria scraps NAPEP, FRC, merges aviation agencies. Retrieved January 28, 2017, from http://www.premiumtimesng.com/news/158312-update-orosanyereport-nigeria-scraps-napep-frc-merges-aviation-agencies.html

Rieffel, L. (2005). Nigeria's Paris Club Debt Problem. Washington DC: The Brookings Institution.

Riegner, M. (2016). Governance Indicators in the Law of Development Finance: A Legal Analysis of the World Bank's 'Country Policy and Institutional Assessment'. Journal of International Economic Law, 19, 1-26.

Rostow, W. W. (1960). The Stages of Economic Growth A Non-Communist Manifesto (1st ed.). Cambridge: Cambridge University Press.

Rwanda Eye. (2016, June 9). Rwanda to spend Rwf 1949.4 billion in 2016/17 fiscal year. Retrieved June 16, 2017, from http://rwandaeye.com/rwanda-to-spend-rwf-1949-4-billion-in-201617-fiscal-year/

Rwandafile. (n.d.). Appeal to the Bahutu Conscience (With the Hutu Ten Commandments). Retrieved October 24, 2016, from http://www.rwandafile.com/Kangura/k06a.html 
Sachs, J. (2002). Resolving the Debt Crisis of Low-Income Coutnries. Brookings Papers on Economic Activity, 2002(1), 257-286.

Salaudeen, L. (2016, May 11). Wanted: equitable revenue sharing formula. Retrieved March 19, 2017, from http://thenationonlineng.net/wanted-equitable-revenue-sharing-formula/

Sankara, T. (1987, July). A United Front Against the Debt. Addis Ababa: Committee for the Abolition of Illegal Debt.

Schäfer, H.-B., \& Cooter, R. (2011). Solomon's Knot: How Law Can End the Poverty of Nations (1st ed.). Princeton: Princeton University Press.

Sen, A. (2000). Role of Legal and Judicial Reform in Development. World Bank Legal Conference, Washington, DC. Washington DC: World Bank.

Senate of the Federal Republic of Nigeria. (2005). REPORT OF THE CAMPAIGN FOR DEBT RELIEF TO NIGERIA'S PRINCIPAL CREDITOR COUNTRIES UNDERTAKEN BY A NATIONAL ASSEMBLY TEAM IN. Abuja: Debt Management Office Nigeria.

Shah, A. (2005, July 2). The Scale of the Debt Crisis. Retrieved November 4, 2016, from http://www.globalissues.org/article/30/the-scale-of-the-debt-crisis

Shihata, I. (1995). The World Bank in a Changing World. Selected Essays and Lectures (2 ed.). The Hague : Martinus Nijhoff Publishers.

Siems, M. (2011). Measuring the Immeasurable: How to Turn Law into Numbers. In M. Faure, \& J. Smits (Eds.), Does Law Matter? On Law and Economic Growth. Cambridge: Intersentia.

Smith, A. (1776). The Wealth of Nations (1st ed.). Scotland: Strahan and Caddell.

Soludo, C. (2017, March 10). The Hard Facts To Rescue The Nigerian Economy. Retrieved March 14, 2017, from http://saharareporters.com/2017/03/10/hard-facts-rescue-nigerian-economy-chukwuma-charlessoludo

Soludo, C. C., \& Ogbu, O. (2004). The Politics of Trade and Industrial Policy in Africa. Forced Consensus? In C. C. Soludo, O. Ogbu, \& H.-J. Chang (Eds.), A Synthesis of Major Themes in the Political Economy of Trade and Industrialisation in Africa (pp. 111-134). New Jersey: Africa World Press.

Stein, H. (2003). Rethinking African Development. In H. J. Chang (Ed.), Rethinking Development Economics. London: Anthem Press.

Stiglitz, J. E. (2008). Is there a Post-Washington Consensus Consensus? In N. Serra, \& S. J. E (Eds.), The Washington Consensus Reconsidered: Towards a New Global Governance (pp. 41-56). Oxford: Oxford University Press.

Tadaferua, K. (2016, November 2). Buhari's \$30 Billion Loan: A Looming Trap. Retrieved March 14, 2017, from http://opinion.premiumtimesng.com/2016/11/02/buharis-30-billion-loan-looming-trap-ken-tadaferua/

Tamanaha, B. Z. (1995). The Lessons of Law and Development Studies. Journal of International Law, 89, 470486.

Teniola, E. (2013, October 24). The Broken Promises of Debt Relief. Retrieved November 3, 2016, from http://icirnigeria.org/the-broken-promises-on-debt-relief/

The Economist. (2013, January 12). Aid to Rwanda. Retrieved March 24, 2017, from http://www.economist. com/news/middle-east-and-africa/21569438-will-rwandas-widely-praised-development-plans-now-bestymied-pain

The Guardian. (2012, October 26). World Bank business rankings obscure poverty and corruption, critics argue. Retrieved June 4, 2017, from https://www.theguardian.com/business/economics-blog/2012/oct/26/ world-bank-business-rankings-poverty-corruption

Toussaint, E. (2004, April 12). Rwanda: The Financiers of the Genocide. Retrieved October 20, 2016, from http://www.cadtm.org/spip.php?page=imprimer\&id_article=611

Toye, J. (2003). Changing Perspectives in Development Economics. In H. J. Chang (Ed.), Rethinking Development Economics (pp. 21-40). London: Anthem Press.

Trubek, D. M. (1996). Law and Development: Then and Now. Proceedings of the Annual Meeting (American Society of International Law), 90, 223-226.

Trubek, D. M., \& Galanter, M. (1974). Scholars in Self-Estrangement: Some Reflections on the Crisis in Law and Development Studies in the United States. Wisconsin Law Review, 1974(4), 1062-1103. 
Tung, K.-Y. (2002). The Rule of Law (Speech to the Federal Judicial Council of Argentina). Buenos Aires: World Bank.

UK Parliament Select Committee on International Development. (1998). International Development- Third Report. London: UK Parliament.

Ulen, T. (2011). The Role of Law in Economic Growth and Development. In M. Faure, \& J. Smits (Eds.), Does Law Matter? On Law and Economic Growth. Cambridge: Intersentia.

Umoru, H. (2017, October 10). Buhari writes Senate to borrow \$5.bn to finance 2017 budget. Retrieved October 22, 2017, from https://www.vanguardngr.com/2017/10/buhari-writes-senate-borrow-5-bnfinance-2017-budget/

United Nations. (1945). Charter on the United Nations CHAPTER I: PURPOSES AND PRINCIPLES. San Francisco: United Nations.

United Nations. (2015, September). Historic New Sustainable Development Agenda Unanimously Adopted by 193 UN Members. Retrieved April 4, 2017, from http://www.un.org/sustainabledevelopment/blog/2015/ 09/historic-new-sustainable-development-agenda-unanimously-adopted-by-193-un-members/

United Nations Conference on Trade and Development . (2016). The DMFAS Programme. Geneva: United Nations Conference on Trade and Development .

United Nations Development Program. (2003). The HIPC Initiative- A Practice Note (UNDP Policy Note). New York: United Nations Development Program.

United Nations Economic Commission for Africa. (2015). Rwanda Country Profile. Addis Ababa: United Nations Economic Commission for Africa.

United Nations General Assembly. (1962). Resolution on Permanent Sovereignty over Natural Resources. New York.

United Nations General Assembly. (1962). Resolution on the Permanent Sovereignty over Natural Resources. New York: United Nations .

United Nations General Assembly. (1974). New International Economic Order. New York: United Nations.

United Nations. (n.d.). Goal 17: Revitalise the Global Partnership for Sustainable Partnership. Retrieved March 13, 2017, from http://www.un.org/sustainabledevelopment/globalpartnerships/

United Nations Industrial Development Organization. (2016). Industrial Development Report 2016. Vienna: United Nations Industrial Development Organization.

United Nations Industrial Development Organization. (2016, September 6). Industrialization in Africa and Least Developed Countries. Vienna: United Nations Industrial Development Organization.

United Nations Millennium Project. (2006). What They Are. Retrieved November 11, 2016, from http://www.unmillenniumproject.org/goals/

United Nations Monetary and Financial Conference. (1944). Articles of Agreement International Monetary Fund and International Bank for Reconstruction and Development. Bretton Woods, N.H.

United Nations Office of the High Commissioner for Human Rights. (2011). The United Nations Rule of Law Indicators Implementation Guide and Project Tools. United Nations.

United Nations. (n.d.). Rwanda: A Brief History of the Country. Retrieved October 20, 2016, from http://www.un.org/en/preventgenocide/rwanda/education/rwandagenocide.shtml

Ushie, V. (2010). CSEA Working Paper WPS/10/002. Implementing the Fiscal Responsibility Act at the State Level in Nigeria. Abuja: Centre for the Study of African Economies.

Uwiringiyimana, C. (2015, February 26). Rwanda sees bigger budget deficit in 2014/15, cites aid delays. Retrieved June 16, 2016, from http://af.reuters.com/article/rwandaNews/idAFL5NOW00LU20150226

Villanova, J. C., \& Martin, M. (2001). The Paris Club. London: Debt Relief International.

Watkins, K. (1994). Debt Relief for Africa. Journal of African Political Economy, 21(62), 599-609.

Watson, A. (1976). Legal Transplants and Law Reform. LQR, 92.

Watson, A. (1991). Legal Origins and Legal Change. London : Hambledon Press.

Watson, A. (1993). Legal Transplants: An Approach to Comparative Law (2nd ed.). Athens: University of Georgia Press.

Weber, M. (1968). Economy and Law (Sociology of Law). In G. Roth, \& C. Wittich (Eds.), Economy and Society. An Outline of Interpretive Sociology (pp. 641-729). Berkeley: University of California Press. 
Williamson, J. (1990). What Washington Means by Policy Reform. In J. Williamson (Ed.), Latin American Adjustment: How Much Has Happened? Washington DC: Institute for International Economics.

World Bank . (2015). Country Policy and Institutional Assessment. Retrieved June 24 , 2016, from http://data.worldbank.org/data-catalog/CPIA

World Bank . (2016). Debt Relief Facts October 2016. Washington DC: World Bank.

World Bank. (1989). Sub-Saharan Africa: From Crisis to Sustainable Growth. Washington D.C: World Bank.

World Bank. (1992). Governance and Development. Washington D.C: World Bank.

World Bank. (1992). World Bank Adjustment Lending and Economic Performance in Sub-Saharan Africa in the 1980s A Comparison with Other Low-Income Countries. 1982: World Bank.

World Bank. (1994). Nigeria Structural Adjustment Programme Policies, Implementation, and Impact. Washington DC: World Bank.

World Bank. (2000). Reforming Public Sector Institutions and Strengthening Governance. Washington DC: World Bank.

World Bank. (2001). Lending Instruments. Washington DC: World Bank.

World Bank. (2001). Operations Policy and Country Services, Adjustment Lending Retrospective: Final Report. Washington D.C.

World Bank. (2004). Heavily Indebted Poor Countries Factsheet- Annual Meetings 2004. Washington DC: World Bank.

World Bank. (2005). Review of World Bank Conditionality. Washington DC: World Bank.

World Bank. (2014). Country Policy and Institutional Assessment Frequently Asked Questions. Washington DC: World Bank.

World Bank. (2014, October 9). Debt Sustainability Framework (DSF). Retrieved March 13, 2017, from http://www.worldbank.org/en/topic/debt/brief/dsf

World Bank. (2014, September 30). International Bank for Reconstruction and Development. Retrieved November 12, 2016, from http://www.worldbank.org/en/about/what-we-do/brief/ibrd

World Bank. (2015). Debt Management Performance Assessment (DeMPA) Methodology (English). Washington DC: World Bank.

World Bank. (2015). Products and Services. Retrieved November 10, 2016, from http://www.worldbank.org/ en/projects-operations/products-and-services

World Bank. (2016). CPIA debt policy rating (1=low to 6=high). Retrieved April 4, 2017, from http://data.worldbank.org/indicator/IQ.CPA.DEBT.XQ

World Bank. (2016). Doing Business Report Series. Washington D.C: World Bank.

World Bank. (2017). About the World Bank. Retrieved February 19, 2017, from http://www.worldbank.org/ en/about

World Bank. (2017). Central Government Debt, Total (\% of GDP). Retrieved August 11, 2017, from http://data. worldbank.org/indicator/GC.DOD.TOTL.GD.ZS?end=2016\&locations=US-

JP\&start=1989\&view=chart

World Bank. (2017). DataBank / Country Policy and Institutional Assessment. Retrieved June 24, 2017, from http://databank.worldbank.org/data/reports.aspx?source=country-policy-and-institutional-assessment\#

World Bank. (2017). DataBank Country Policy and Institutional Assessment. Retrieved April 3, 2017, from http://databank.worldbank.org/data/reports.aspx?source=country-policy-and-institutional-assessment

World Bank. (2017). Worldwide Governance Indicators. Retrieved April 4, 2017, from http://info.worldbank. org/governance/wgi/\#home

World Bank Group. (2015). DC2015-00072015 Shareholding Review Report to Governors 2015. Washington DC: World Bank and the International Monetary Fund.

World Bank. (n.d.). Where Does the World Bank Get Its Money. Retrieved November 12, 2016, from http://siteresources.worldbank.org/ESSDNETWORK/Resources/481106-1129303936381/1777397-

1129303967165/1777403-1129304010757/where_does.html

Xanthaki, H. (2008). Legal Transplants in Legislation: Defusing the Trap. The International and Comparative Law Quarterly, 57(3), 659-673. 
Yelwa, A. J. (2010, September 7). Debt Management in Nigeria: Fiscal Responsibility and Public Debt - by Alhaji (Dr) Aliyu Jibril Yelwa. Abuja: Nigerian Muse: http://www.nigerianmuse.com/20130907011016zg/ nigeria-watch/debt-management-in-nigeria-fiscal-responsibility-and-public-debt-by-alhaji-dr-aliyu-jibrilyelwa/. 



\section{Acknowledgments}

This PhD thesis was borne of, and driven by a burning question - how can laws and legal systems enable the economic development of the African continent? The last three years have been an interesting interrogation of the interplay and interaction of laws and economies. It is my hope that through this thesis, I can contribute to enhancements of legal institutions and economic performance in the parts of the world commonly described as developing.

Firstly, I thank my supervisors, Professor Peter Van den Bossche, whose enthusiasm and kind support at the commencement of the research project bolstered my confidence and commitment. Professor Michael Faure encouraged me to venture into the wide and wonderful field of law and development. I am especially grateful for his friendly and relentless interrogation of my assumptions, alongside the painstaking reviews of the thesis, delivered with humour. Also, I thank Mr. Chidi Ilogu (SAN), for his probing questions and helpful comments.

I am grateful for the opportunities offered by the Mandela Institute for Development Studies to explore the themes of this thesis through their publications and conferences. Also, I appreciate the efforts towards interviews and data collection, which were greatly facilitated by BudgIT in Nigeria, and Mr. Felix Nugee of the Ministry of Finance and Economic Planning in Rwanda.

My friends, Akin Ajao and Rumbidzai Chisenga are thanked and appreciated for their enduring support, and diligent editing of thesis chapters.

This project would not have been possible without the generosity, care and support of my family, especially my mother, Azuka Ogo. I am deeply grateful. To my siblings, cousins and friends who provided moral support and encouragement, I would like to say thank you.

Most of all, my deepest appreciation is to the Almighty God for His faithfulness, and enablement. To Him be all Praise and Glory. 



\section{Curriculum vitae}

Ifeyinwa Ogo holds a BA in Law and Politics (2010) and an LLM in Law and Development (2013) from the University of London, United Kingdom. Ifeyinwa began her career with the United Nations, and has worked as a consultant to multilateral agencies and the Nigerian Government. Also, she works on social ventures across Africa. Currently, she is a Fellow at the United Nations Economic Commission for Africa. 